\title{
MANAGEMENT PLAN AND CONSERVATION STRATEGIES FOR SAGE GROUSE IN MONTANA - FINAL
}

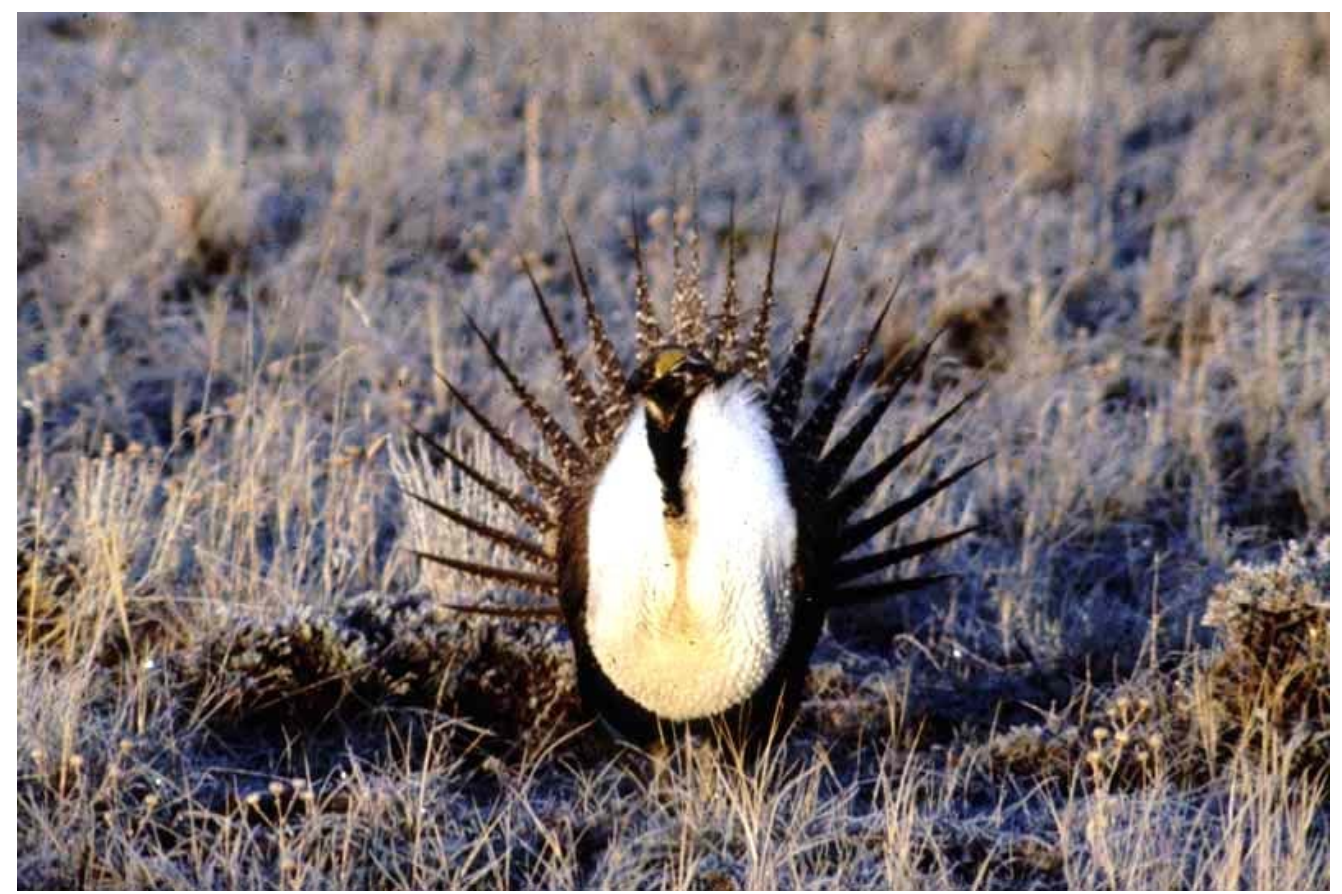

Image by Bob Martinka

Prepared by:

Montana Sage Grouse Work Group

Rev. 2-1-2005 


\section{EXECUTIVE SUMMARY}

Growing concern about the status of sagebrush (Artemisia spp.) on western rangelands and declines in sage grouse (Centrocercus urophasianus) numbers have led to petitioning the Fish and Wildlife Service of the U.S. Department of Interior to protect populations in some western states under provisions of the federal Endangered Species Act. Loss of sagebrush-grasslands in some western states has approached or exceeded 50 percent. Such habitat loss in Montana, in terms of quality or quantity, may not have been as high as in other states although significant enough at least in part of the state to influence sage grouse numbers and population trends.

A Memorandum of Understanding (MOU) for the conservation and management of sage grouse was signed by member states of the Western Association of Fish and Wildlife Agencies

(WAFWA) and federal natural resource management agencies. Members of these organizations have agreed to work cooperatively to develop conservation plans for sage grouse in each of 11 western states. Each state member of WAFWA agreed to convene a working group within 60 days of the effective date of the MOU-12 July 2000.

\section{Purpose of the Plan}

Montana's conservation strategy provides for coordinated management across jurisdictional boundaries and development of community support that will promote successful implementation. Participants in the Montana sage grouse work group (SGWG) who have developed the plan include representatives of federal and state agencies, tribal representatives, private organizations, and several individuals from the general public, all of whom have an interest in the issue of sage grouse conservation.

The plan establishes a process to achieve sage grouse management objectives and provide a framework to guide local management efforts and coordinated management across jurisdictional boundaries. Regional or local groups will adapt and implement strategies from the statewide plan to improve or maintain the sagebrush steppe in their respective geographical areas. Throughout development of the plan, numerous views were expressed that emphasized the need to keep sage grouse management in balance with social, cultural, and community values.

The overall goal of the plan is to "Provide for the long-term conservation and enhancement of the sagebrush steppe/mixed-grass prairie complex within Montana in a manner that supports sage grouse and a healthy diversity and abundance of wildlife species and human uses." Objectives include maintaining the distribution and integrity of sagebrush steppe communities and maintaining the distribution of sage grouse populations within the mountain foothills mixed sagebrush and Wyoming big sagebrush-silver sagebrush ecotypes based on a consistently applied monitoring protocol.

\section{Distribution and Habitat Needs of Sage Grouse}

Sage grouse are native to the sagebrush steppe of western North America, and their distribution closely follows that of sagebrush, primarily big sagebrush (A. tridentata). Distribution of sage grouse in Montana includes the eastern one-half and southwest corner of the state - roughly 27 million acres (11 million ha) of sagebrush-grassland in 39 counties. 
In eastern Montana, where close interspersion of wintering, nesting, and brood-rearing habitat rarely require large seasonal movements, sage grouse are essentially nonmigratory. Some sage grouse in southwestern Montana are migratory, moving between separate summer and winter areas. Migratory movements of sage grouse also have been documented between eastern Idaho and southwest Montana. Seasonal movement often is elevational and related to availability of herbaceous vegetation during late summer and early fall. The following seasonal habitats are important for survival of sage grouse:

- Breeding Habitat.- - Strutting grounds or "leks," where breeding actually occurs, are key activity areas and most often consist of clearings surrounded by sagebrush cover. Findings from research in central Montana reported a sagebrush canopy cover at feeding and loafing sites in the vicinity of leks of 20-50 percent with an average of 32 percent.

- Nesting Habitat. - Sage grouse invariably prefer sagebrush for nesting cover, and quality of nesting cover directly influences nest success. Successful nesting requires concealment provided by a combination of shrub and residual grass cover. Sage grouse most frequently select nesting cover with a sagebrush canopy of 15-31 percent. Research findings in central Montana suggest that about two-thirds of nests occur within 2 miles of a lek.

- Brood-Rearing Habitat.-Areas providing an abundance and diversity of succulent forbs, an important summer food source for young sage grouse, provide key brood-rearing habitat. Research in central Montana indicated that sage grouse broods prefer relatively open stands of sagebrush during summer, generally with a canopy ranging from 1-25 percent. As palatability of forbs declines, sage grouse move to moist areas that still support succulent vegetation, including alfalfa fields, roadside ditches, and other moist sites. During summers of high precipitation, sage grouse in Montana may remain widely distributed throughout the entire summer due to the wide distribution of succulent forbs. Sage grouse in southwest Montana and eastern Idaho often move to intermountain valleys during late summer where forbs remain succulent through summer and early fall. Reported sagebrush canopy on these sites varied from 8.5 to 14 percent.

- Winter Habitat. - Sage grouse generally select relatively tall and large expanses of dense sagebrush during winter. Wintering areas in central Montana included sagebrush stands on relatively flat sites with a 20-percent canopy and an average height of 10 inches. The importance of shrub height increases with snow depth. Thus, snow depth can limit the availability of wintering sites to sage grouse.

\section{Population Dynamics}

Counts of males on leks during spring have been used to provide an index of relative size and trend of breeding populations of sage grouse in Montana since the 1950s. Statewide, sage grouse numbers increased from the mid-1960s through 1973 and fluctuated about that level until 1984. Sage grouse declined rather sharply statewide from 1991 through 1996 and increased through 2000. Long-term harvest trends, based on post-hunt surveys of hunters, when interpreted along with lek counts, also provide insight to long-term changes in sage grouse numbers at a statewide scale. 
Productivity has been estimated from examination of wings of grouse taken by hunters. In addition to the quantity and quality of breeding and nesting habitat, the amount and timing of spring and summer rainfall may affect annual production and population dynamics of sage grouse. Nest success and early brood survival rates are some of the most significant vital rates influencing population dynamics of prairie grouse and other upland nesting species.

Juvenile mortality during the first few weeks after hatching is typically high and can increase when drought reduces availability of important food sources, such as insects and forbs, or herbaceous understory, used as hiding and escape cover. Research documented an average mortality rate of 56 percent in central Montana from the egg-laying period in April to early September.

Survival rates for adult sage grouse are generally considered to be high, and thus population declines are usually not related to high levels of predation on adult birds. Adult hens are most vulnerable to predation during the nesting period, whereas adult males are most vulnerable during the spring breeding season.

\section{Management}

Sage grouse are managed as an upland game bird under state legislative authority including the statutory mandate of the Fish, Wildlife and Parks Commission to regulate harvest.

FWP, in conjunction with federal land management agencies and conservation groups, monitors prairie grouse populations during spring through census of displaying males on leks. The postharvest telephone survey provides an estimate of harvest for all upland bird species, trend in hunter numbers, and number of birds by species taken by hunters. FWP uses wings from harvested sage grouse to estimate composition of the harvest by sex and age, although some regions discontinued collections during the mid-1980s.

State-funded cooperative habitat projects have the potential to benefit sage grouse on private and other non-tribal land. In 1987, the Montana Legislature created a process and funding source for FWP to acquire conservation easements on or to purchase important wildlife habitat in Montana. The program generates funding from an earmarked portion of license revenue and provides an innovative tool to protect habitat at the state level. The Upland Game Bird Habitat Enhancement program, which authorizes FWP to use earmarked funds for habitat improvement for upland game birds, also was enacted in 1987 and amended in 1989. It too allows for the use of conservation easements and habitat enhancement to improve conditions for sage grouse.

\section{Issues Requiring Conservation Actions}

During the conservation planning effort, the Montana sage grouse work group identified risks to sage grouse and their habitat. The group then identified 12 major issues in sage grouse conservation and, considering the social and economic implications posed by the risks themselves, developed possible conservation actions to reduce those risks. The issues are: 
- Fire Management.- Benefits, detriments, and relative frequency of fire on sage grouse habitats often are subjects of disagreement. Use of prescribed fire in the sagebrush community can result in a net loss of sagebrush and concerns those desiring to maintain a mature sagebrush community. Some land managers consider fire an effective tool to manage sagebrush stands with dense sagebrush cover and suppressed herbaceous cover. Both prescribed and wild fires can have cumulative effects on sagebrush habitat and wildlife species that depend on it.

- Grazing Management.-Many western rangelands were over-stocked with livestock in the late-1800s and early 1900s, thus altering the composition and productivity of some sagebrush and other vegetative communities. The effects of livestock on sage grouse habitat, and on the birds, may be positive, negative, or neutral depending on the specific grazing prescription and on the ecological site. To minimize the potential impact of removing important understory vegetation, flexible grazing management programs need to be planned and implemented while considering the needs of sage grouse. Research is needed to identify and evaluate the effects of various grazing management plans on the interaction of sage grouse, commodity production, and other societal values.

- Harvest Management.- Sage grouse generally have the lowest average productivity rate of any upland bird in Montana but also are one of the longest lived. Although some believe that hunting is detrimental, the direct effects of hunting on sage grouse are still small when compared to other forms of mortality. Topics of disagreement, however, go beyond any direct effects. Some question why hunters may still pursue sage grouse while use of rangeland resources could be restricted. Yet others believe that eliminating or curtailing hunting only digresses from habitat issues, which are directly linked to the species' status. A strategy of adaptive harvest management should be implemented to reduce uncertainty about the effects of harvest on sage grouse populations.

- Noxious Weed Management.-Noxious weeds have spread across Montana at an unprecedented rate. Landowners/managers have a statutory responsibility to develop management plans for the treatment of noxious weeds on land they own and/or manage, although the magnitude of weed infestations often prevents appropriate and timely treatment. Noxious weeds displace more desirable native plant species and cause significant adverse biological and economic effects by reducing productivity of healthy rangeland. Chemical control of weeds is efficient although it poses some short-term toxicological risk to sage grouse and other wildlife. Reduction of forbs important to sage grouse during brood rearing could have more serious consequences, with the magnitude of these effects dependent on the scale of treatment.

- Mining and Energy Development.- Many of the nation's oil and gas resources lie under sage grouse habitats across the western U.S., from which development and production activities could potentially affect sage grouse if habitats are lost, fragmented, or degraded. Effects of oil and gas development on sage grouse are not extensively documented, however, and long-term impacts after reclamation are not clearly understood. 
- Outreach and Education.- Effective conservation of sage grouse requires collaboration between federal and state land and wildlife managers, private landowners, tribal governments, extension service, and other interests to develop and implement appropriate regional protection strategies. Implementation of a Montana sage grouse conservation plan requires a sound biological foundation. Most information about shrub-steppe habitats and sage grouse is contained in technical manuscripts. However, conservation of sage grouse and other sagebrush-associated species requires local involvement and userfriendly information.

- Power Lines and Generation Facilities.-Power lines provide additional hunting perches for raptors in otherwise treeless areas. Power lines most likely impact grouse near leks, in brood-rearing habitat, and in wintering areas that also support large numbers of wintering raptors. Construction of new power lines contributes to habitat degradation when accompanied by new roads or other infrastructure, e.g., pipelines, fences, etc. Utilities commonly make power poles safe for raptors to use as perches, which poses a dilemma in sage grouse habitat.

- Predation.- The effects of predators on sage grouse populations and issues surrounding predator control concern landowners, wildlife managers, and the public. Composition and abundance of avian and mammalian predator populations have changed since termination of widespread predator control in the early 1970s. Although many native mammals and birds may prey upon sage grouse eggs, juveniles, or occasionally adults, grouse populations cycle from lows to highs despite ongoing predation. Livestock producers view a loss of livestock to predators as an economic loss, but they also perceive predators as a threat. Wildlife managers view predators taking wildlife as an expected component of natural mortality.

- Recreational Disturbance.- Sage grouse may draw human recreational activities such as viewing, monitoring, and photographing, to seasonally important habitats. Monitoring sage grouse populations and habitats is essential at leks and other critical habitats. Recreation and monitoring should be considered cumulatively as part of assessing approaches for managing human disturbance of sage grouse.

- Roads and Motorized Vehicles.- Roads and off-road travel can impact sage grouse and their habitats in a variety of ways that include habitat fragmentation and loss and a potential decline and/or shift in grouse populations. Vehicle use on federal, state, and tribal lands, both on and off roads, has increased significantly over the past few years and has impacted habitat quality. Severity of impacts may be directly related to the amount of vehicle travel occurring.

- Vegetation.- Past management of rangelands, including plowing, has altered the density, structure, composition, and presence of sagebrush communities and has in some cases created a variety of conditions that do not meet the desired condition described for sage grouse seasonal needs. Restoring or enhancing sage grouse habitats requires diverse strategies. Disagreements often arise regarding the ecological role, or successional 
relationships, of "old" or "decadent" stands of sagebrush, the need to manipulate sagebrush communities, method of control, and extent of treatment.

- Managing Other Wildlife in Sage Grouse Habitat. - The effect of other species of native herbivores, e.g., large ungulates and prairie dogs, on habitats that they share with sage grouse may be problematic if intensive use and foraging degrades the quality of habitats that grouse use for nesting and brood-rearing. Streamside riparian areas, springs, wet meadows, and other mesic sites, which also attract other herbivores, become increasingly important as the summer season progresses. Periods of drought often increase adverse impacts. Successfully resolving or mitigating these potential conflicts with wild herbivores depends on willingness of managers to objectively assess impacts that might occur as a result of excessive herbivory and other land uses.

In developing conservation strategies, the Montana sage grouse work group also considered published guidelines for sage grouse populations and habitats (Connelly et al. 2000b, Guidelines to manage sage grouse populations and their habitats, Wildlife Society Bulletin, 28:967-985, provided in the Appendix). Although not incorporated as such into the strategies, the guidelines are recognized as presenting some of the best biological recommendations for sage grouse, and many of these recommendations are reflected in the conservation actions laid out by the document. 


\section{TABLE OF CONTENTS}

EXECUTIVE SUMMARY.

TABLE OF CONTENTS. viii

A GUIDE TO USING THIS DOCUMENT

INTRODUCTION

Purpose of the Plan...

Guiding Principles.

SECTION I: CONSERVATION GOAL AND OBJECTIVES $\ldots \ldots \ldots \ldots \ldots \ldots \ldots \ldots \ldots . .4$

GOAL STATEMENT ................................................ 4

HABITAT OBJECTIVES AT MULTIPLE SCALES....................... 4

Broad Scale Habitat Objectives................................... 4

Mid-Scale Habitat Objectives....................................... 5

Fine Scale Habitat Objectives................................... 6

POPULATION OBJECTIVES .......................................... 7

Maintain Distribution........................................... 7

Figure I-1. Distribution of Sage Grouse Habitat in Montana

Table I-1. Sagebrush Ecological Units by Sub-Unit, FWP Region, and County

Maintain or Increase Numbers.................................... 9

Table I-2. Population Distribution and Trend Information by FWP Region

Table I-3. Population Objectives by FWP Region

SECTION II: LEGAL FRAMEWORK AND AGENCY COMMITMENTS.......... 12

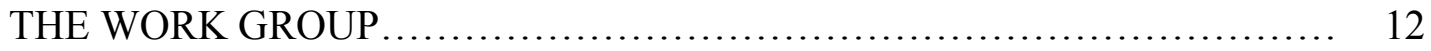

STATE MANDATES AND POLICIES ................................ 12

Montana Fish, Wildlife, and Parks (FWP)...................... 12

Montana Department of Natural Resources and Conservation (DNRC),

Trust Land Management Division (School Trust Lands)......... 14

FEDERAL MANDATES AND POLICIES .............................. 15

U.S. Forest Service (FS) ..................................... 15

Natural Resources Conservation Service (NRCS)................... 15

Bureau of Land Management (BLM) ............................... 16

National Wildlife Refuge System (NWR), U.S. Fish and

Wildlife Service (FWS) .................................. 17

Tribal Authority and Jurisdiction................................... 18

AGENCY COMMITMENTS TO THIS PLAN............................. 19

Montana Fish, Wildlife, and Parks (FWP)........................ 19

Department of Natural Resources and Conservation (DNRC)........... 21

U.S. Forest Service (FS) ..................................... 21

Natural Resources Conservation Service (NRCS)................... 22

Bureau of Land Management (BLM) ........................... 23 
SECTION III: STATUS OF SAGE GROUSE IN MONTANA........................ 25

GEOGRAPHIC DISTRIBUTION......................................... 25

North America................................................... 25

Montana....................................................... 25

HABITAT USE IN MONTANA....................................... 25

Range of Movement............................................ 25

Figure III-1. Current and historical distribution of sage grouse in Montana.

Breeding ........................................................ 26

Summer-Fall.................................................... 27

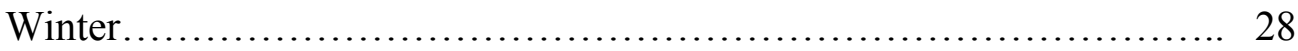

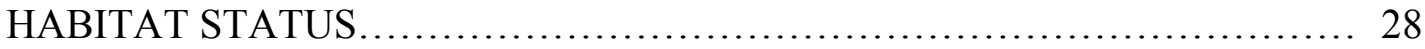

POPULATION DYNAMICS .............................................. 29

Change Over Time.................................................... 29

Table III-1. Summary Of Long-Term Sage Grouse Lek Surveys In Montana, 1955-2001

Reproduction.................................................... 31

Figure III-2. Trends in sage grouse lek counts and harvest in Montana, 19622000

Mortality.....

Table III-2. Sage Grouse Production From Statewide Collection Of Wings

From Hunter-Killed Birds, 1962-2002

POPULATION STATUS.................................................. 35

Status Through the $20^{\text {th }}$ Century..................................... 35

Status Throughout Montana........................................... 35

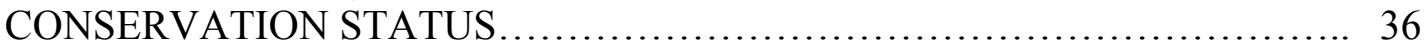

Legal Status....................................................... 36

Management in Montana.......................................... 37

SECTION IV: HABITAT ...................................................... 39

DESIRED CONDITION OF SEASONAL HABITATS...................... 40

Breeding/Nesting Habitat.......................................... 40

Table IV-1. Habitat Characteristics Of Associated Sage Grouse Nest Sites

(From Connelly et al. 2000; Heath et al. 1998)

Brood Habitat.......................................................... 41

Winter Habitat................................................. 42

Figure IV-1. Distribution Of Sage Grouse In Central Montana By Cover Type And Sagebrush Density (From Wallestad 1975)

MAJOR SAGEBRUSH ECOTYPES ..................................... 43

Use of Ecotypes for Management.................................... 43

Mountain Foothills Mixed Sagebrush............................... 43

Wyoming Big Sagebrush-Silver Sagebrush.......................... 44

Figure IV-2. Map Of Major Sagebrush Ecotypes

SECTION V: PROBLEMS CONFRONTING THE SPECIES....................... 45

RISKS IN GENERAL ................................................ 45

Habitat: Loss, Fragmentation, Degradation........................... 45 
Physical Threats to Sage Grouse................................... 47

RISKS BY ECOTYPE................................................. 48

Mountain Foothills Mixed Sagebrush.............................. 48

Wyoming Big Sagebrush-Silver Sagebrush......................... 48

SECTION VI: CONSERVATION ACTIONS.................................. 49

ADAPTING WAFWA GUIDELINES TO MONTANA SAGEBRUSH

HABITATS......................................................... 49

CONSERVATION ISSUES AND ACTIONS............................. 49

Fire Management.............................................. 50

Harvest Management............................................. 53

Livestock Grazing Management.................................... 55

Mining and Energy Development................................. 59

Noxious Weed Management...................................... 62

Outreach, Education, and Implementation............................ 65

Power Lines and Generation Facilities................................ 67

Predation........................................................ 71

Recreational Disturbance of Sage Grouse............................ 73

Roads and Motorized Vehicles.................................... 74

Vegetation...................................................... 76

Managing Other Wildlife in Sage Grouse Habitats....................... 80

SECTION VII: ASSESSMENT, MONITORING, AND RESEARCH NEEDS........... 82

HABITAT ASSESSMENT AT MULTIPLE SCALES........................ 82

Purposes and Limitations.......................................... 82

Using the Assessment Framework................................. 82

MID-SCALE INFORMATION AND ASSESSMENT USE ..................... 83

The Mid-Scale Unit.................................................. 83

Mid-Scale Mapping ............................................ 84

FINE-SCALE INFORMATION AND ASSESSMENT USE ................. 85

The Fine Scale Unit........................................... 85

Population Information............................................ 85

Vegetation and Habitat Information................................ 86

PROJECT OR SITE LEVEL ASSESSMENT ............................. 87

General Considerations......................................... 87

Location and Timing............................................. 87

Table VII-1. Location and Timing of Evaluation

Using Worksheets and Evaluation Criteria.............................. 89

Breeding Habitat.................................................. 89

Table VII-2. Nesting And Early Brood-Rearing Habitat Features And

Indicators For The Habitat-Assessment Matrix

Late Brood-Rearing Habitat....................................... 91

Table VII-2. Late Brood-Rearing Habitat Features And Indicators For The

Habitat Assessment Matrix

Winter Habitat. 
Table VII-3. Winter Habitat Features And Indicators For The Habitat Assessment Matrix

Organizing Site Evaluations at the Project Area Level.................. 92

LEK MONITORING: GUIDELINES FOR AERIAL AND GROUND SURVEY 94

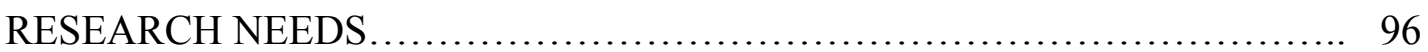

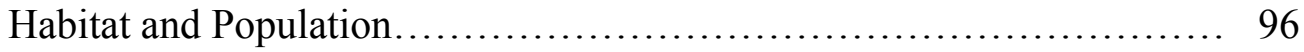

Specific Needs................................................. 97

SECTION VIII: COORDINATION AND OVERSIGHT .......................... 98

PLAN MONITORING, EVALUATION AND ADAPTIVE

IMPLEMENTATION ........................................... 98

LOCAL WORKING GROUPS............................................ 98

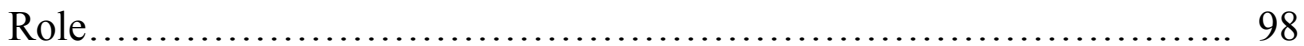

Organization.................................................. 99

Figure VIII-1. Anticipated Locations Of Local Groups

Other Considerations............................................... 101

SECTION IX: ADDRESSING ENDANGERED SPECIES CRITERIA................ 103

Factor 1: Habitat.................................................... 104

Factor 2: Over-Utilization.......................................... 105

Factor 3: Disease or Predation...................................... 105

Factor 4: Existing Regulation..................................... 106

Factor 5: Other Factors........................................... 107

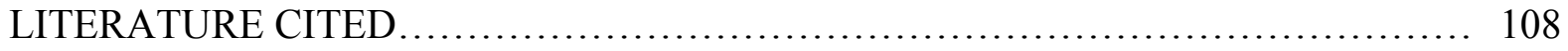

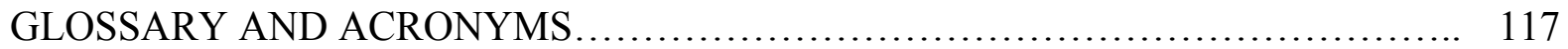

MEETING PARTICIPANTS ............................................. 127

AGENCY SIGNATORY PAGE .............................................. 129

NON-GOVERNMENTAL ORGANIZATION SIGNATORY PAGE................. 130

APPENDICES............................................................. 131
A. WAFWA Guidelines
B. Habitat Assessment Tools
C. Adaptive Harvest Strategy
D. Lek Monitoring Tools
E. Summary of Public Comments with Responses 


\section{A GUIDE TO USING THIS DOCUMENT}

The Management Plan and Conservation Strategies for Sage Grouse in Montana is organized into 9 sections plus an introduction and appendices. Each section has its own subset of page numbers.

The INTRODUCTION describes background as to why the sage grouse planning effort was organized, the purpose for the Plan, and principles used to guide its development.

SECTION I includes the overall goal of the Plan as well as more specific habitat management objectives at 3 different geographic scales and population distribution and abundance objectives by ecotype and FWP Region.

SECTION II describes the impetus for organizing the Montana Sage Grouse Work Group, the legal mandates of each agency involved, as well as each agency's commitment to sage grouse conservation in Montana.

SECTION III describes the status of sage grouse in Montana in terms of their distribution, seasonal habitat use, habitat, population level and dynamics, and conservation.

SECTION IV details the seasonal habitat needs of sage grouse and describes the two sagebrush ecotypes in Montana.

SECTION V describes risks confronting sage grouse in Montana and more specifically within the two sagebrush ecotypes.

SECTION VI details 12 specific conservation issues that affect sage grouse and provides management actions that can be used to conserve sage grouse and their habitats.

SECTION VII describes habitat assessments at three geographic scales for measuring sage grouse habitat quality. This section also describes the lek monitoring protocol and research needs related to sage grouse conservation.

SECTION VIII describes how the plan will be implemented and how its progress will be monitored and evaluated. This section details the role and organization of local working groups and function of the statewide local working group coordinator.

SECTION IX recounts how the Plan will meet the conservation needs of sage grouse from the perspective of federal Endangered Species Act listing criteria. 


\section{INTRODUCTION}

Montana sportsmen, resource managers, landowners, other conservation interests have been concerned about the status of sage grouse (Centrocercus urophasianus) and/or sagebrush (Artemisia spp.)-grasslands since the 1950s. Loss of sagebrush steppe across the western states approaches or even exceeds 50 percent in some areas (Dobler 1994, Knick 1999) and is considered to be a primary reason for long term declines in sage grouse abundance across their range (Schroeder et al. 2000, Connelly and Braun 1997). Loss of sagebrush habitat in Montana, in terms of quality or quantity, may not have been as high as in other states although significant enough in part of the state to influence sage grouse population trends (e.g., Swenson et al. 1987). The best available information for Montana suggests breeding populations have declined by as much as 30 percent (Connelly and Braun 1997).

Growing concern about the status of sagebrush steppe, declines in sage grouse numbers, and long-term survival of sage grouse populations resurfaced in the 1990s. A Memorandum of Understanding (MOU) for the conservation and management of sage grouse was signed by member states of the Western Association of Fish and Wildlife Agencies (WAFWA) and federal natural resource management agencies on 12 July 2000. The U.S. Forest Service (under the U.S. Department of Agriculture) and the Bureau of Land Management and Fish and Wildlife Service (both under the U.S. Department of Interior), agreed to work cooperatively with member states to develop conservation plans. Each state member of WAFWA agreed to convene a work group within 60 days of the effective date of the MOU.

\section{Purpose of the Plan}

This plan is the product of the Montana Sage Grouse Work Group (SGWG). It provides for coordinated management across jurisdictional boundaries and development of community support that will assure successful implementation. Participants in the SGWG include representatives of federal and state agencies, tribal representatives, private organizations, and several individuals from the general public, all of whom have a stake in the issue. A complete list of participants is included in the Appendix.

The plan is designed to provide biological information, identify information gaps, and facilitate data collection required for future resource management decisions. The plan is dynamic and flexible to include new issues and adjust to local situations. It establishes a process to achieve sage grouse management objectives and provides a framework to guide local management efforts. Regional or local groups will adapt the statewide plan to develop and implement strategies in respective geographic areas that will improve or maintain the sagebrush steppe and reduce or mitigate factors that may further reduce habitats or populations.

\section{Guiding Principles}

Throughout development of the plan, numerous views were expressed that emphasized the need to keep sage grouse management in balance with social, cultural, and community values. The following guiding principles are intended to guide development of the conservation plan and provide a foundation for selecting appropriate management actions during implementation. Local 
or regional work groups may identify additional principles to guide local efforts, but at a minimum they will function under these principles:

1) Conservation actions implemented for sage grouse will contribute to the overall health of sagebrush communities across the landscape.

2) Conservation strategies will integrate local, regional, and national needs for conservation planning.

3) Wildlife professionals, land managers, private landowners, and all others who have a stake in sagebrush communities will be tolerant, understanding, and respectful of other perspectives and focus on areas of common interest.

4) This plan is not intended to exclude any uses or activities or infringe on legally defined private property rights; rather, it serves to provide solutions to problems and address issues that negatively affect sage grouse and degrade sagebrush community health. 


\section{SECTION I: CONSERVATION GOAL AND OBJECTIVES}

\section{GOAL STATEMENT}

The Montana SGWG adopted the following goal: Provide for the long-term conservation and enhancement of the sagebrush steppe/mixed-grass prairie complex within Montana in a manner that supports sage grouse, a healthy diversity and abundance of wildlife species, and human uses.

\section{HABITAT OBJECTIVES AT MULTIPLE SCALES}

Sage grouse and other species that occupy the sagebrush ecosystems of Montana depend for their long-term viability on the wide diversity of plants, their growth forms, and their distribution upon the landscape. Greater sage grouse require different habitat conditions to meet yearlong needs - often across broad landscapes. Risks to habitats or populations (see Section V) occur at all scales and may be additive in some situations. To understand all factors contributing to habitat quality, land managers are encouraged to assess conditions at multiple scales (Broad-, Mid-, Fine-) within a spatial context, using a step-down process. We developed habitat objectives at these three scales to determine to what extent goals for sage grouse are being achieved.

\section{Broad-scale Habitat Objectives}

At the broadest scale, the extent of sagebrush across Montana, adjacent states (Idaho, Wyoming, North and South Dakota), and Canada should be assessed. A comparison of historical and current distribution of sage grouse and sagebrush across the broad scale may help determine how largescale patterns of habitat loss and degradation have affected distribution of sagebrush ecosystems and associated wildlife species. Habitat objectives at the broader, coarse scale have been developed within this context to meet seasonal and annual needs of sage grouse and other wildlife species of the sagebrush steppe as well as those of other resource users. It is noteworthy that not all sagebrush communities in Montana provide habitat for sage grouse.

1) Maintain the distribution of sagebrush across all of the current range to support sage grouse and a healthy diversity and abundance of wildlife species and human uses, acknowledging that short-term, i.e., $<50 \mathrm{yrs}$, localized losses of sagebrush-grassland will occur. However, losses due to manipulation and conversion should be offset such that they result in no net loss in overall distribution and quality of sagebrush habitat.

2) Maintain or enhance the integrity of sagebrush-steppe communities within ecologically similar areas that include inter-mountain valleys of southwestern Montana, the plains of central Montana, broad drainages of southeast Montana, and the glaciated plains of northcentral and northeast Montana. 


\section{Mid-scale Habitat Objectives}

The mid-scale typically is assessed at a basin or sub-basin level. For this plan, the mid-scale is divided into two ecotypes that are described more fully in Section IV:

- Mountain Foothills Mixed Sagebrush in southwest Montana

- Wyoming Big Sagebrush-Silver Sagebrush throughout central and eastern Montana.

Examining landscape patterns of sagebrush, e.g., distribution of patches, patch size and connectivity, helps us understand ecosystem processes, disturbance regimes, and current versus historical conditions. Combining information about landscape patterns with data about the structure, composition, and ecological condition of sagebrush communities gives us the ability to assess whether conditions are favorable to sage grouse and other sagebrush-dependent species. Sage grouse habitats that are identified as supporting stable or increasing populations would carry a priority for maintenance. Recent efforts to reclassify sagebrush cover using improved remote sensing technology and training data offer a tool to complete mid-scale assessments.

Within this context, habitat objectives at the mid-scale are developed:

1) Shrub cover capable of supporting the life history requirements of sage grouse and other wildlife that use sagebrush should be present across the ecological unit. This should include a variety of patch sizes that emphasize areas with a central core of habitat in large contiguous blocks. All patches of habitat should be well dispersed throughout the range as determined in the broad-scale objective. Patches may be configured in blocks, islands, corridors, and mosaic patterns, but they should be arranged such that connectivity is maintained.

2) At a mid-scale level, continue to refine Montana's land cover type map for sagebrush. Within each ecological unit, determine the appropriate range and distribution of canopy cover classes for each sagebrush alliance. Shrub cover should include a mix of height classes with a herbaceous understory adequate for meeting seasonal habitat requirements of sage grouse (see WAFWA Guidelines in the Appendix).

a) In habitats consisting of predominately silver sagebrush (see Section IV), manage sites with the potential to support sagebrush in a manner that maintains at least 50 percent of those areas in canopy cover of $<1$ to 25 percent.

b) In habitats with predominately mountain big sagebrush in southwest Montana, manage sites with the potential to support sagebrush in a manner that maintains $\geq 70$ percent of those areas in canopy cover of 5 to $>25$ percent.

c) In habitats that include predominately Wyoming big sagebrush, manage sites with ecological potential to maintain sagebrush over at least 60 percent of those areas in a canopy cover of 5 to $>25$ percent.

3) Maintain a herbaceous understory emphasizing multiple species of native forbs and grasses. 
4) Emphasize restoration and rehabilitation of sagebrush in areas that are capable of supporting sagebrush and contribute to the distribution and connectivity of patches.

\section{Fine-scale Habitat Objectives}

The area of analysis for fine scale assessment is a management unit such as a watershed, allotment, or pasture that can be evaluated with quantitative information. The desired condition relies on site potential, ability of the site to meet seasonal needs of sage grouse, and/or other available information. Measurements of shrub and herbaceous cover are often required.

Wildlife objectives for sagebrush communities will be determined based on: a) local knowledge about current habitat use, b) potential to support a variety of species including sage grouse, c) existing native shrub cover patterns and sagebrush-associated characteristics, d) existing herbaceous cover and condition, e) frequency and reasonably foreseeable likelihood of disturbance, e.g. fire, f) locations of seedings or condition of shrub cover on adjacent areas, and g) importance of the area to seasonal needs of sage grouse.

Habitat objectives at the fine-scale are developed within this context:

1) Maintain distribution and condition of sagebrush and herbaceous cover within the context of mid-scale objectives (see Section IV).

2) Maintain or manage for a diverse herbaceous understory emphasizing native species.

3) Manage vegetation characteristics, i.e., shrub height, density, herbaceous structure, and composition, to maintain diversity across the range of conditions specified by the mid-scale objective (see "WAFWA Guidelines" in the Appendix). Based on local knowledge about current habitat use by sage grouse, the vegetation characteristics and desired condition of the area may vary depending on the seasonal use by sage grouse (see Section IV), other wildlife species, and/or other resource values, e.g., livestock grazing.

4) Emphasize restoration and rehabilitation of sagebrush communities in areas that are capable of supporting sagebrush and contribute to the distribution and condition of habitat for seasonal uses. For example, crucial winter habitats, which typically are a fraction of the sagebrush available on wintering areas, carry a high priority for maintenance or restoration.

5) Modify activities and management actions on public land and/or private land under federal or state-funded programs to reduce or minimize habitat loss if such actions would degrade or fragment sage grouse habitat. 


\section{POPULATION OBJECTIVES}

\section{Maintain Distribution}

Objectives.--Maintain the current distribution of sage grouse in Montana within the two broad sagebrush ecological types and their subunits. Maintain sage grouse numbers within the range of documented population cycles in areas of largely unfragmented sagebrush habitat and increase sage grouse numbers in those areas where habitat fragmentation has reduced populations and conservation actions can restore the biological potential of those areas for sage grouse. Over the next 50 years, maintain the current distribution of sage grouse in Montana (Fig. I-1) within two broad sagebrush ecological types as described in Table I-1.

Within these broad units, there are physiographic and environmental differences that can be used to separate certain geographic areas; however, these types transition across the landscape, and therefore discrete boundaries from a sagebrush-mapping standpoint become subjective. These broad categories include:

- the higher-elevation (>4000') Mountain Foothills Mixed Sagebrush Ecotype of southwestern and south-central Montana characterized by a more complex sagebrush association (portions of FWP Administrative Regions 3, 4, and 5)

- the Wyoming Big Sagebrush-Silver Sagebrush Ecotype that extends from southeastern Montana and transitions through the central portion of the state into the glaciated northcentral portion of Montana (portions of FWP Administrative Regions 4, 5, 6, and 7).

The current estimate of potentially occupied sage grouse habitat within these ecotypes in Montana is approximately 27 million acres (11 million ha; FWP 2002). This estimate was based on areas (polygons) mapped by state and federal biologists and delineated using land cover types, including sagebrush classes, from the Montana GAP Analysis and a consolidated NRCS land cover type legend (Fig. I-1). This estimate of potentially occupied sage grouse habitat will be refined as methods are improved for classifying and separating sagebrush vegetation communities, especially at canopy densities $<20$ percent, from native grassland habitat types (Section III, Habitat Status).

In summary, land cover type maps, including sagebrush distribution, were used to map potentially occupied sage grouse habitat. Within each region, varying amounts of potentially occupied sage grouse habitat have been surveyed for sage grouse presence, primarily during the spring breeding season. Over the past three years, additional census efforts have been directed to previously un-surveyed sage grouse habitat during the spring breeding season and wintering period. 
Distribution of Sage Grouse Habitat and Sagebrush Ecotypes in Montana

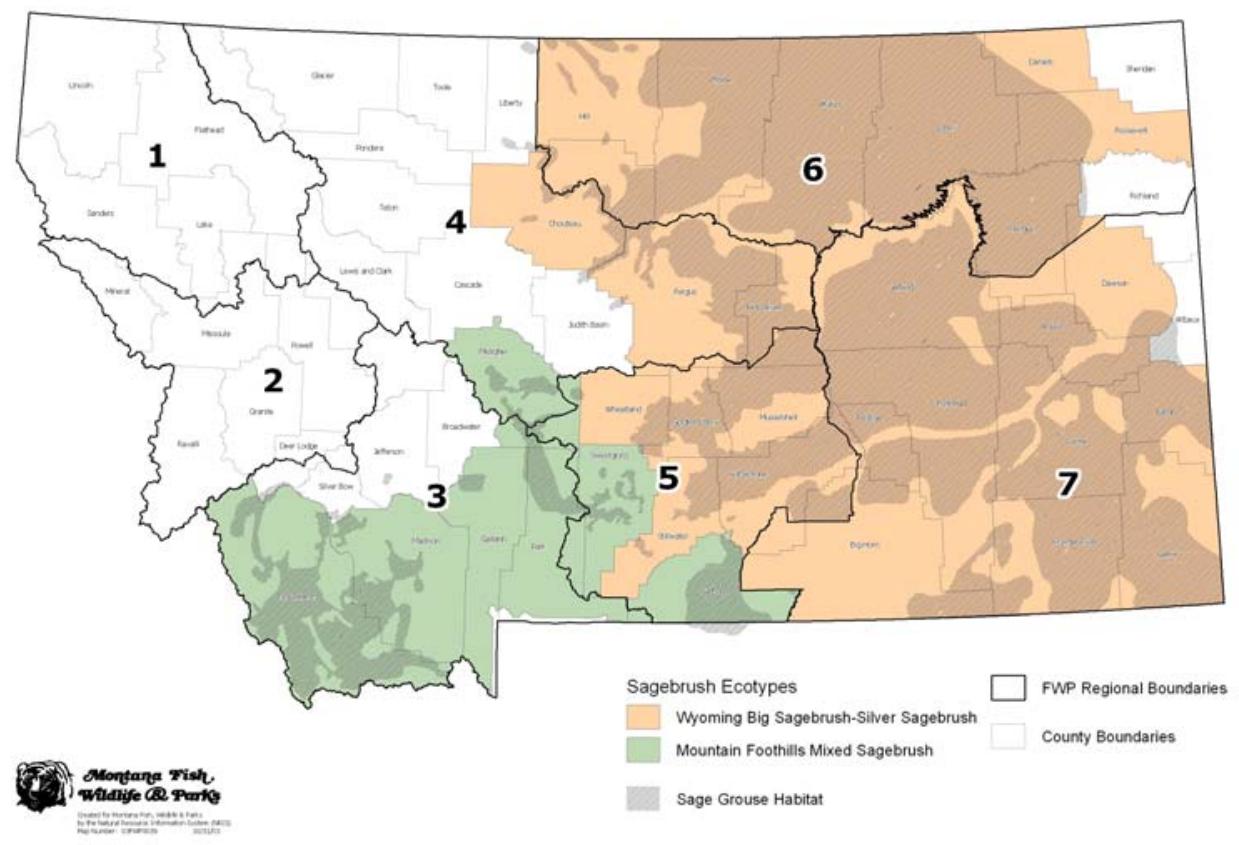

Figure I-1. Distribution of Sage Grouse Habitat and sagebrush ecotypes in Montana. Map provided by FWP Information Services.

Fig. I-1 includes sage grouse distribution information from MFWP and BLM wildlife biologists digitized at varying scales. All other data layers obtained from the Natural Resource Information System.

Table I-1. Sagebrush Ecological Units by Sub-Unit, FWP Region, and County

\begin{tabular}{|c|l|l|}
\hline $\begin{array}{c}\text { Ecological unit } \\
\text { Sub-unit }\end{array}$ & FWP Region & \multicolumn{1}{|c|}{ County } \\
\hline $\begin{array}{c}\text { Mountain Foothills Mixed } \\
\text { Sagebrush }\end{array}$ & & \\
\hline Southwestern & R3, R4, R5 & Beaverhead, Madison, Park, Meagher, Sweetgrass \\
\hline South Central & R5 & Carbon \\
\hline $\begin{array}{c}\text { Wyoming Big Sagebrush-Silver } \\
\text { Sagebrush }\end{array}$ & & \\
\hline Southeastern & R5, R7 & $\begin{array}{l}\text { Carter, Powder River, Dawson, Wibaux, Big Horn, Custer, } \\
\text { Fallon, Prairie }\end{array}$ \\
\hline Central & $\begin{array}{l}\text { R4, R5, R6, } \\
\text { R7 }\end{array}$ & $\begin{array}{l}\text { Stillwater, Wheatland, Yellowstone, Golden Valley, } \\
\text { Musselshell, Treasure, Rosebud, Fergus, Petroleum, } \\
\text { Garfield, McCone, Chouteau, South Blaine, South Phillips, } \\
\text { South Valley }\end{array}$ \\
\hline North Central & R6 & $\begin{array}{l}\text { Northern Blaine, Northern Phillips, Northern Valley, Hill, } \\
\text { Daniels, Roosevelt }\end{array}$ \\
\hline
\end{tabular}




\section{Maintain or Increase Numbers}

Objective.--Over the next 50 years, maintain or increase sage grouse numbers as measured by a consistently applied monitoring protocol.

Table I-2 summarizes the current estimate of total sage grouse habitat (potentially occupied) and currently surveyed sage grouse habitat by FWP Region, the number of active leks by region, and an estimate of lek density expressed as a function of square miles of surveyed habitat per active lek. Table I-2 also presents trends in counts of male sage grouse on surveyed leks as an index to changes in annual and long-term abundance. The parameters include:

- the 25-year long-term average of male attendance per lek by region

- the 2001 counts for the average number of males per lek during a recent population high by region.

These parameters provide a long-term index to grouse density and habitat carrying capacity. In addition, the average number of males observed per lek provides an index to trends in annual abundance.

Table I-2. Population Distribution and Trend Information By FWP Region

\begin{tabular}{|c|c|c|c|c|c|c|}
\hline $\begin{array}{l}\text { FWP } \\
\text { region }\end{array}$ & $\begin{array}{l}\text { Acres of total } \\
\text { sage grouse } \\
\text { habitat }^{1} \text { and } \\
\text { percent of } \\
\text { statewide total }\end{array}$ & $\begin{array}{l}\text { Acres of } \\
\text { surveyed sage } \\
\text { grouse habitat } \\
\text { and percent of } \\
\text { total regional } \\
\text { sage grouse } \\
\text { habitat }\end{array}$ & $\begin{array}{l}\text { Number } \\
\text { of active } \\
\text { leks per } \\
\text { region }\end{array}$ & $\begin{array}{l}\text { Lek } \\
\text { density - } \\
\text { mi }^{2} \text { of } \\
\text { surveyed } \\
\text { habitat per } \\
\text { active lek }^{2}\end{array}$ & $\begin{array}{l}\text { 25-yr ave } \\
\text { males/lek } \\
\text { (number of } \\
\text { leks }^{4} \text { ) }\end{array}$ & $\begin{array}{l}2001 \text { ave } \\
\text { males/lek }\end{array}$ \\
\hline 3 & $2,354,572(9 \%)$ & $963,745(41 \%)$ & 36 & 42 & $27(9)$ & 31 \\
\hline 4 & $1,716,063(6 \%)$ & $1,141,550(66 \%)$ & 103 & 17 & $30(17)$ & 37 \\
\hline 5 & $3,130,366(12 \%)$ & $2,040,715(65 \%)$ & 151 & 21 & $32(31)$ & 37 \\
\hline 6 & $8,423,301(31 \%)$ & $3,911,445(46 \%)$ & 133 & 46 & $21(11)$ & 30 \\
\hline 7 & $11,438,332(42 \%)$ & $4,706,220(41 \%)$ & 353 & 21 & $22(27)$ & 26 \\
\hline
\end{tabular}

${ }^{1}$ Estimated acres of potentially occupied sage grouse habitat (MFWP 2002).

${ }^{2}$ Calculated by dividing square miles of nesting/brood rearing habitat (MFWP 2002) by the total number of active/probably active leks.

${ }^{3}$ For the period 1977-2001.

${ }^{4}$ Only leks with a 10 -year string of survey data were used.

Benchmarks for these parameters may change as more of the unsurveyed but potentially occupied habitat is inventoried, as leks with $\geq 10$ consecutive years of population trend information are added to the data set, and as baseline vegetation maps are refined. Although the objectives for average male attendance per lek are stated in terms of population peaks (Table I3 ), note that monitoring programs provide annual snapshots of grouse populations at various points in the population cycle. These can be used to interpret progress toward conservation goals. 
Information presented in Table 1-2 was used to generate the population objectives that are quantified in Table 1-3. These include maintaining the specified lek density by region, expressed as square miles of surveyed habitat per active lek, and maintaining average male attendance during population highs as noted. The table also documents both the low and high counts for average number of males during periods of low abundance and peak abundance as a point of reference for population fluctuations that will likely occur. The average number of males observed during the recent population peak in 2001 (Table I-2) represents approximately 92 percent of the lek attendance objectives listed in Table I-3. The exceptions are Region 3, where ongoing land conversion activities continue to reduce the amount of sage grouse habitat in Park and Meagher Counties, and Region 7, where the 2000 lek attendance numbers were the highest recorded during the 25-year period.

In addition to continuing annual surveys of leks with long data strings, a new lek sampling strategy is being developed by FWP that will measure long-term statewide sage grouse abundance and distribution trends (Section VII, Research Needs).

Table I-3. Population Objectives By FWP Region

\begin{tabular}{|l|l|l|l|}
\hline $\begin{array}{l}\text { FWP } \\
\text { regions }\end{array}$ & $\begin{array}{l}\text { Lek density objective - } \\
\mathbf{m i}^{2} \text { of surveyed } \\
\text { habitat per active lek }\end{array}$ & $\begin{array}{l}\text { Lek attendance objective - } \\
\text { ave males/lek in FWP } \\
\text { region during population } \\
\text { highs }\end{array}$ & $\begin{array}{l}\text { Documented range of lek } \\
\text { attendance during } \\
\text { population highs and lows }\end{array}$ \\
\hline $\mathbf{3}$ & 42 & 35 & $\begin{array}{l}\text { High - 46 (1977) } \\
\text { Low - 14 (1994) }\end{array}$ \\
\hline $\mathbf{4}$ & 17 & 40 & $\begin{array}{l}\text { High - 43(1982) } \\
\text { Low - 19(1990) }\end{array}$ \\
\hline $\mathbf{5}$ & 21 & 40 & $\begin{array}{l}\text { High - 44 (1991) } \\
\text { Low - 14 (1994) }\end{array}$ \\
\hline $\mathbf{6}$ & 46 & 32 & $\begin{array}{l}\text { High - 37 (1984) } \\
\text { Low - 12(1986) }\end{array}$ \\
\hline $\mathbf{7}$ & 21 & 32 & $\begin{array}{l}\text { High - 35(2000) } \\
\text { Low - 12(1985) }\end{array}$ \\
\hline
\end{tabular}

Recent genetic analysis (Oyler-McCance et al. 2001) indicates that Montana sage grouse are representative of a single population with good genetic diversity (broad-scale assessment). The genetic signature, or dominant haplotypes, of these birds does vary across the state and demonstrates important geographic linkages with sage grouse in Idaho, Wyoming, and to a lesser extent North Dakota, and the provinces of Alberta and Saskatchewan. Certain population segments may be isolated geographically, and low numbers of grouse in these locations may warrant special attention. However, conservation efforts in highly fragmented habitats where grouse numbers have declined will be more costly and less effective than maintaining large blocks of sagebrush habitat with healthy grouse populations.

Trends in population status, habitat quantity and quality, and potential risks to the population may vary by Ecotype or by Ecotype sub-unit; they can be assessed at a mid-scale level, e.g., FWP Administrative Regions, involving multiple counties and/or large watersheds. 
Fine scale assessments of local grouse abundance and/or habitat issues will likely be targeted at specific geographic areas within a one- to two-county complex, or within single counties stepped down to a drainage system, or large grazing management units. Development of local work groups concentrating on specific focus areas will assist in the delivery of appropriate conservation strategies. Current databases are structured around the county as the discrete data unit. Information could be queried and displayed at a sub-county level where appropriate for specific management questions, although sample sizes may be small for such units. 


\section{SECTION II: LEGAL FRAMEWORK AND AGENCY COMMITMENTS}

\section{THE WORK GROUP}

A MOU for the conservation and management of sage grouse was signed by member states of WAFWA and federal natural resource management agencies. Thus, federal agencies agreed to work cooperatively with member states to develop conservation plans. Each state member of WAFWA agreed to convene a work group within 60 days of the effective date of the MOU and act as a lead in developing a conservation plan. Participants in the Montana SGWG include representatives of federal and state agencies, tribal representatives, private organizations, and several individuals from the general public, all of whom have a stake in the issue and were brought together to develop the conservation plan.

Individual agencies have different missions and objectives, and thus, will contribute to the objectives of this plan in different ways. This section describes the responsibility of each agency to provide a level of management to conserve sage grouse and sagebrush habitats.

\section{STATE MANDATES AND POLICIES}

\section{Montana Fish, Wildlife and Parks (FWP)}

The basic statutory authority provided by the Montana legislature assigns FWP supervision of the state's wildlife resources. A governor-appointed director and a five-member Fish, Wildlife and Parks Commission oversee operations and set policy and regulations, respectively. In broad terms, FWP's legal mandate to manage Montana's wildlife includes:

$\mathrm{X}$ Management of all the wildlife of the state, including game, nongame, and threatened and endangered species, enforcement of wildlife laws and rules, and provision of wildlife-related recreational opportunity (87-1-201 and 87-5-101, MCA).

$\mathrm{X} \quad$ Authority to accept federal funding through the Pittman-Robertson Act (87-1-708, MCA) and use of hunting license revenue for department purposes (87-1-710).

$\mathrm{X}$ Authority and funding to acquire a legal interest in land through easement, lease, or purchase to protect wildlife habitat (87-1-241and 242, MCA).

$\mathrm{X}$ Authority and funding to enhance habitat for upland game birds (87-1-246, MCA).

FWP's responsibility and authority to supervise Montana's wildlife (87-1-201, MCA) are administered through its Wildlife Program, which is coordinated at the statewide level and implemented through seven administrative regions. The Strategic Plan for the Wildlife Program, developed through a programmatic environmental impact statement (EIS) under the Montana Environmental Policy Act (75-1-101, MCA), provides direction that covers all FWP's actions related to wildlife in the state.

The Strategic Plan addresses current and future demands for wildlife-related recreation and strengthens FWP's role as a steward of Montana's wildlife and habitats. Issues for which the 
document was developed included recreational access, recreational opportunity, species and habitat management, commercial uses of wildlife, and landowner relations. Programs and strategies developed to address these issue also might affect management of sage grouse and their habitat - these strategies are listed here.

Recreational access includes the following programs and strategies:

- Expand access-related enforcement and information and education (I\&E) programs to encourage good landowner/sportsman relationships and emphasize protection of land and wildlife resources. Increase emphasis on the full range of opportunities, dispersing users, and creating awareness of impacts of outdoor recreation on wildlife and habitats.

- Manage roads on Wildlife Management Areas (WMAs) to accommodate hunter harvest without compromising human safety or vegetation and soil resources.

- Stress wildlife and habitat protection in easements, leases, and purchases under FWP's Habitat Montana policy. Encourage acquiring access on a case-by-case basis.

- Respond to proposals for managing motorized travel and other access issues on public land to benefit wildlife, habitats, and recreational opportunity over the long term.

Efforts to manage recreational opportunity include the following:

- Continue to emphasize trapping and hunting as tools to manage wildlife while providing recreation.

- Expand efforts to delist T\&E species and prevent listing of other species by emphasizing habitat programs, such as the Habitat Montana or Upland Game Bird Enhancement programs on private and public lands.

Efforts to manage species and habitats include the following:

- Develop a consistent statewide policy for wildlife species introductions directed at expanding recreational opportunity.

- Attempt to influence reauthorization of the federal Endangered Species Act to increase state authority in T\&E management decisions.

- Monitor species that are indicators of overall ecosystem health.

- Increase emphasis on maintaining and protecting habitat at an ecosystem level while continuing to focus management of harvestable wildlife on individual species or species groups.

- Expand Habitat Montana projects to acquire legal interest in high priority, critical habitats.

- Provide technical expertise to appropriate agencies according to existing laws and guidelines.

- Work with private landowners, public agencies, and other cooperators to enhance habitats. FWP is responsible for providing technical and cost-share assistance for restoration, enhancement, and creation of wildlife habitat on private land under the Upland Game Bird Enhancement Program. 
- Emphasize long-term research driven by regional and statewide priorities for wildlife and habitat.

Efforts to maintain a working relationship with private landowners include the following:

- Recognize landowners as partners in determining primary areas for predator control actions (FWP's annually contributes $>\$ 100,000$ to DOL for predator control). This approach shifts the focus from broad application of aerial gunning of coyotes to areas where coyotes may be effectively preying on both livestock and wildlife.

- Explore incentives and alternate methods to reduce the impact of predators on wildlife and livestock.

- Control noxious weeds on FWP land consistent with state law. FWP recognizes that weed infestation is a serious issue and that the agency must do more to solve the problem than meeting its legal mandate as a landowner.

- Increase emphasis on biological control of weeds and assistance to landowners who consider wildlife habitat.

- Explore collaborative opportunities at the local level to address weed control on areas outside of and adjacent to FWP-controlled land.

\section{Montana Department of Natural Resources and Conservation (DNRC), Trust Land Management Division (School Trust Lands)}

When Montana became a state through the Enabling Act approved February 22, 1889, the U.S. Congress granted to it sections 16 and 36 in every township within the state for the monetary support of the common school system. Some of these sections had been homesteaded, some were within the boundaries of Indian reservations, and yet others were otherwise disposed of prior to the passage of the Enabling Act. In lieu of these sections, the state selected other land. In addition to the common school grant, the Enabling Act and subsequent acts granted acreage for other education and state institutions. There are currently 5.1 million surface acres and 6.3 million acres of subsurface trust land distributed across the state.

The Enabling Act provided that the proceeds from the sale and management of any trust land constitute permanent funds for the support and maintenance of the public schools and various state institutions. Rentals received on leased land, interest earned on the permanent fund, and all other income is distributed annually to the schools and institutions. The Trust Land Management Division distributed more than $\$ 49$ million in earnings and interest directly to the schools in FY 2000 .

The Montana Constitution (Article X, Section 4) established the Board of Land Commissioners (Land Board) to oversee the management of trust land (MCA 77-1, Part 2). The Land Board consists of the statewide elected officials: Governor, Attorney General, Auditor, Secretary of State, Superintendent of Public Instruction.

The Trust Land Management Division of DNRC manages the surface and mineral resources for the benefit of the common schools and other endowed institutions, under the direction of the Land Board. Its obligation for management and administration of trust land is to obtain the 
greatest benefit for the school trusts. The greatest monetary return must be weighed against the long-term productivity of the land to ensure continued future returns to the trusts. The division's mission: Manage the State of Montana's trust land resources to produce revenues for the trust beneficiaries (Montana's schools) while considering environmental factors and protecting the future income generating capacity of the land.

State land management must comply with Montana Constitutional provisions for a clean and healthful environment (Article 2, Section 3, and Article 9, Section 1) and with all state and federal law, including:

- The federal Endangered Species Act (ESA) of 1973 (PL 93-205), section 9

- The Montana Environmental Policy Act (75-1-101 et. Seq., MCA)

- The Montana Non-game and Endangered Species and Conservation Act (87-5-101 et. Seq., MCA).

\section{FEDERAL MANDATES AND POLICIES}

\section{U.S. Forest Service (FS)}

The Multiple-Use Sustained Yield Act (1960) requires the FS to maintain the diversity of plant and animal communities within a Forest plan area. Regulations (CFR 219.19 date 1982 and 2001) that implement both the Multiple-Use Sustained Yield Act and the National Forest Management Act (1976) require that habitat be maintained such that viable populations of native and desirable non-native species are well distributed across a planning area. Supporting this law is the Secretary of Agriculture's policy (9500-4) directing the agency to manage habitats for native and desirable nonnative species such that at least viable populations of these species are maintained.

The Forest Service Manual (2670.32) directs the FS to assist states setting management goals for endemic species and to avoid or minimize impacts to species where viability has been identified as a concern. It is FS policy to establish management objectives in cooperation with the states when projects on National Forest System lands may have a significant effect on sensitive species population numbers or distributions.

The Forest Service, Region 1, designated sage grouse as a "sensitive" species in 1995. It is FS policy to protect the habitat of federally listed (proposed, threatened, or endangered) or FS Sensitive Species from adverse modification or destruction, as well as to protect individual organisms from harm or harassment as appropriate (FSM 2670.3).

\section{Natural Resources Conservation Service (NRCS)}

Within the basic authority provided by the Soil Conservation and Domestic Allotment Act of 1935 (Public Law 74-76, 49 Stat. 163, 16 U.S.C 590q-f) as amended, NRCS assists private landowners with management and conservation of soil, water, air, plant, and animal resources. 
With respect to wildlife species and their habitats, this includes providing routine biology planning assistance, integrating fish and wildlife considerations into all conservation plans, informing landowners of opportunities and alternatives available for managing wildlife habitat, and avoiding/minimizing adverse impacts to wildlife during all of its planning activities.

The National Environmental Policy Act (NEPA) of 1970 (PL 91-190) requires NRCS to counsel with other agencies in evaluating effects of its conservation planning and implementation and to advocate protection of valuable wetlands, threatened/endangered species, and designated ecosystems. The Endangered Species Act (ESA) of 1973 (PL 93-205) requires NRCS to assure that its conservation planning assistance does not adversely affect T\&E species or their habitats; it is NRCS policy that this also applies to species of special concern.

NRCS is responsible for providing technical and cost-share assistance for restoration, enhancement, and creation of wildlife habitat on private land under the Wildlife Habitat Incentives Program. NRCS commonly partners with the U.S. Fish and Wildlife Service, Montana Fish, Wildlife and Parks, and private wildlife management organizations in meeting this responsibility. Under the Conservation Reserve Program, NRCS assists private landowners with restoration of rare and declining habitats, including sagebrush/grasslands, a priority habitat under this practice.

\section{Bureau of Land Management (BLM)}

BLM responsibilities and mandates to conserve species and diversity include the following:

- Federal Land Policy and Management Act of 1976, PL 94-579, Sec. 102 (a) (8)... public land will be managed in a manner that will protect the quality of scientific, scenic, historical, ecological, environmental, air, and atmospheric, water resource, and archeological values; that, where appropriate, will preserve, and protect certain lands in their natural condition; that will provide food and habitat for fish and wildlife and domestic animals; and that will provide for outdoor recreation and human occupancy and use.

- BLM 6840 - Special Status Species Management. State directors, usually in cooperation with state wildlife agencies, may designate sensitive species. BLM shall carry out management, consistent with the principles of multiple use, for the conservation of sensitive species and their habitats and shall ensure that actions authorized, funded, or carried out do not contribute to the need to list any of these species as T\&E.

- Fundamentals for Standards for Rangeland Health (43 CFR 4180.1). The fundamentals require at a minimum that habitats are, or are making significant progress toward being, restored or maintained for federal threatened and endangered species, federal proposed or candidate species, and other special status species. Standards establish a minimum required condition, which addresses habitat quality for native plant and animal populations and communities. 


\section{National Wildlife Refuge System (NWR), U.S. Fish and Wildlife Service (FWS)}

Sage grouse and sagebrush habitat in the National Wildlife Refuge System (NWR) are managed under the authority of several federal laws, regulations, and policies.

- The National Wildlife Refuge System Improvement Act of 1997 states: "The mission of the National Wildlife Refuge System is to administer a national network of lands and waters for the conservation, management, and where appropriate, restoration of the fish, wildlife, and plant resources and their habitats within the United States for the benefit of present and future generations of Americans." FWS is currently soliciting public input on draft policies on NWR's Mission, Goals and Purposes, Appropriate Uses, Wildlife-Dependent Recreational Uses, and Wilderness Stewardship Policy (Federal Register, January 16, 2001, 66(10):3668-3731).

- FWS recently issued its final policy on Biological Integrity, Diversity, and Environmental Health (Federal Register January 16, 2001, 66(10):3810-3823). The authority for this policy is the National Wildlife Refuge System Administration Act of 1966 as amended by the National Wildlife Refuge System Improvement Act of 1997, 16 U.S.C. 668dd-668ee. Section 4(a)(4)(B) of the Improvement Act states that "In administering the System, the Secretary shall...ensure that the biological integrity, diversity, and environmental health of the System are maintained ...". Conservation of sage grouse and their habitat is required of the FWS for the maintenance of biological integrity, diversity and environmental health. Working with partners, on and off FWS-owned lands, is consistent with the FWS philosophy of ecosystem management and is provided for in this legislation.

- Challenge cost-share agreements and other partnership arrangements for wildlife and wildlife habitat research and management can be entered into by FWS under the authority of the U.S. Fish and Wildlife Coordination Act 16 U.S.C. 661-667. The Code of Federal Regulations (CFR), Title 50, parts 1-199, detail FWS regulations affecting the take, possession, transportation, etc., of wildlife and plants and management of NWRs.

- Language used in the establishing legislation of a specific refuge may apply to sage grouse management. In the case of the Charles M. Russell NWR (CMR), which contains the vast majority of sage grouse and sage grouse habitat on FWS-owned lands in Montana, wildlife management is carried out under the 1986 Record of Decision finalizing the Final Environment Impact Statement (FEIS) for the Management of CMR. Passage of Public Law 94-223 in 1976 specifically directed that CMR would be managed under the National Wildlife Refuge System Administration Act of 1966.

- The mission of CMR is to "preserve, restore, and manage in a generally natural setting a portion of the nationally significant Missouri River Breaks and associated 
ecosystems for optimum wildlife resources and provide compatible human benefits associated with its wildlife and wildlands." The priority goal for CMR as outlined in the FEIS is to "attain and perpetuate a balanced, natural diversity of plant and animal communities favoring endangered or threatened species, then all other native species, and finally desirable exotics." Another goal listed in the FEIS is to "restore and maintain habitat and other conditions necessary to sustain optimum populations of mammals and nonmigratory birds." Conservation of sage grouse and associated habitats on CMR is one component of maintaining the natural diversity of plant and animal communities in the Missouri River Breaks.

\section{Tribal Authority and Jurisdiction}

The U.S. recognizes Indian tribes as sovereign nations. As such, Indian reservation (tribal) lands are not public lands or part of the public domain and are not subject to state or many public land laws. Tribes exercise inherent sovereign powers over their members and territories, including the authority to manage fish and wildlife resources within their borders. Tribes have jurisdictional authority for fish and wildlife species management and for habitat and land use management on tribal lands. This includes the power to manage and control water and land resources, associated natural resources, and environmental protection. Tribal sovereignty also includes the power to regulate member and nonmember hunting, fishing, and gathering.

The U.S. maintains a fiduciary relationship with Indian people through the trust responsibility. Under this trust responsibility, the U.S. and thus all federal agencies have a legal and moral duty to assist Indian people and tribes with protection of their property and rights. As such, the Secretary of the Interior must manage trust resources for the exclusive benefit, including economic benefit, of the tribes and must assure that the purposes for which reservations were created - as homelands for the use and benefit of Indian people pursuant to the treaties, statutes, and executive orders creating or pertaining to them — are not undermined.

Several statutes, executive orders, secretarial orders, and agency policies outline implementation of the trust responsibility with respect to tribal natural resources and require government-togovernment coordination with tribes. Many federal agencies have Indian policies and active programs to work with tribes regarding natural resource issues. On many reservations, unregulated harvest of certain species has served to decimate local game populations. Many tribes have now established environmental and natural resource agencies and promulgated tribal natural resource laws and regulations in order to regulate such activities by members and nonmembers. In addition, tribes are working to revive cultural traditions and inform younger members of the cultural values and traditional uses of fish and wildlife species.

Unfortunately, past and sometimes ongoing mismanagement of tribal lands and resources by federal agencies also has resulted in loss of fish and wildlife resources and their habitats and the need for restoration and improvement. The trust responsibility reaches far beyond the need to prevent species extinction and requires restoration of habitats and resource productivity to the point where they are capable of sustaining tribal use. 


\section{AGENCY COMMITMENTS TO THIS PLAN}

Nothing in the plan and subsequent conservation actions undertaken are intended to abrogate any of the parties' respective responsibilities and/or authorities. All actions shall be consistent with all federal, state, and tribal authorities and governmental compacts. To the extent possible, consistent with their mission, authorities, responsibilities and budget constraints, each of the following agencies support the Plan's conservation goals and achievement of the habitat and population objectives through conservation actions and habitat maintenance measures described in this Plan.

\section{Montana Fish, Wildlife and Parks (FWP)}

Although not a land management agency, FWP has authority to enter into conservation easements, or land purchases in some cases, to protect and enhance wildlife habitats. FWP has well-demonstrated its ability to work with private landowners. Under the Habitat Montana program, FWP currently holds easements on 65,000 acres of land within the occupied range of sage grouse. FWP manages these properties to conserve native range and wildlife species; covenants are attached that prohibit manipulation of sagebrush habitat, subdivision, or converting native rangeland to cultivated farmland. FWP has developed a managed grazing system, i.e., rest-rotation grazing, for each easement and also has assigned a top priority to sagebrush-grasslands among habitats needing protection and management. This priority would carry into the future. Approximately 10,000 acres have been protected annually in this manner.

FWP's Upland Game Bird Habitat Enhancement Program (UGBHEP) has helped fund rest rotation grazing management systems on 552,000 acres of land through term agreements with private landowners. The program can also be used to re-establish native vegetation and to purchase conservation easements. Sagebrush-grasslands have been a priority of UGBHEP, with approximately 50 percent of funding being used to enhance sagebrush habitats. FWP would expect this contract program to continue into the foreseeable future.

Recently, FWP was awarded a federal grant through the Landowner Incentive Program that will be matched with funds from the state Upland Game Bird Habitat Enhancement Program. This "Sagebrush Initiative" will result in the purchase of sagebrush habitat protection on approximately 183,000 acres of privately owned sage grouse-occupied habitat by June 30, 2006. The 30-year agreements will prohibit conversion to cropland and sagebrush control measures. Should vegetation conditions warrant, or new information become available, these habitat protection agreements would allow for vegetation manipulation activities if they enhance sage grouse habitats and are agreeable between FWP and the cooperator. Priority areas for developing agreements are sagebrush-grasslands within 2 miles of leks as well as documented sage grouse wintering areas. These agreements would not affect grazing practices. After this initial funding is spent, additional funding will likely be pursued for the purchase of additional habitat protection.

Although not a habitat program, FWP also administers the statewide block management program that involved 1,100 landowners in 2002, offering 8.5 million acres of land for public hunting. This, again, demonstrates the private landowners' willingness to work with FWP. 
FWP is responsible for recommending annual harvest regulations to the Fish, Wildlife and Parks Commission, which holds statutory authority to set season length and bag limits. As laid out in the conservation actions in Section VI of this document, FWP intends to recommend the adaptive harvest management strategy described in Appendix C. This harvest strategy will use current lek survey information for deriving season recommendations. That is, bag limits would be adjusted based on a pre-determined lek count threshold. However, if a threatening decline became apparent in one or more ecotype segments (Section IV, Page 43-44), FWP would recommend against opening a sage grouse season in the appropriate segment(s). Based on lek data showing projected high and known low population variation, a threatening decline is defined as 3 or more consecutive years with average lek survey levels at $45 \%$ or more below the long-term average, determined using leks with 10 or more years of consecutive survey data. This mechanism would provide the ability for FWP to recommend not opening a season based on current year's lek-monitoring information.

Over the past 40 years, FWP has collected wings of harvested sage grouse for determining annual levels of productivity and hatching dates, as well as identifying sex ratios of harvested birds (Table III-2). In some parts of Montana, collections were discontinued in the 1980's and collections in some areas were recently re-established. FWP will continue to collect and analyze harvested sage grouse wings in a targeted fashion, primarily to maintain a long-term record of annual sage grouse productivity levels. These collections will be in the form of wing barrels located near popular hunting areas and/or wing-envelopes sent to sage grouse hunters.

FWP will also continue to annually monitor upland game bird harvest on a statewide basis using post-hunt hunter surveys (Figure III-2).

FWP began more intensively surveying sage grouse leks and seasonal ranges in 1999. It is the department's intention to continue to work to locate and digitally map leks and seasonal ranges throughout the range of sage grouse in the state. FWP will work to find funding and establish cooperation with other agencies and private groups to do these more intensive surveys. FWP will work with the interstate Sage Grouse Technical Committee and academia to develop and implement a monitoring scheme that will provide long term statewide sage grouse abundance trends (See also Section VII, Research Needs). FWP will also continue to annually survey the 4 trend areas to measure changes in breeding abundance at a more localized level (Section III).

In cooperation with federal land management agencies, FWP will seek funding for a statewide coordinator to implement portions of this plan carried out at the local level. This position is expected to be in place a minimum of 5 years.

FWP, through contracts with the Natural Resource Information System (NRIS) housed at the State Library, will continue to digitally map and store information pertinent to sage grouse and sagebrush conservation. In addition, FWP's Geographical Information System (GIS) unit will develop programs needed to gather and develop the databases needed to manage and conserve sage grouse and their habitat. 
FWP will continue to provide technical assistance to both federal and state land management agencies relative to the specific habitat needs of sage grouse and will continue to work with public and private sector partners in the refinement of appropriate conservation actions. Similarly, FWP will continue to serve on state and interstate boards, technical committees, and work groups that share a goal of long-term conservation of sage grouse and the sagebrush steppe. As described in Section VIII, FWP will annually compile sage grouse data and conservation accomplishments for evaluation and assessment by the state working group. Staff also will provide technical assistance to local work groups as they become established.

FWP will continue to support conservation measures aimed at preservation of native sagebrush steppe through incentive payments attached to federal legislation such as the Farm Bill.

\section{Department of Natural Resources and Conservation (DNRC)}

Consistent with the fiduciary duty to manage state school trust land for the monetary support of the common school system and other endowed beneficiaries, DNRC will consider the management practices described in the sage grouse plan when conducting activities on state land at the fine scale. DNRC will attempt to mitigate adverse effects from state land management activities in accordance with the plan where such mitigation is possible. DNRC will cooperate in the collection of data regarding sage grouse populations and habitat. DNRC personnel will continue to serve on state work groups and technical committees that promote the long-term conservation of sage grouse. In a manner in keeping with state law, DNRC will consider the use of conservation easements or other similar tools for the conservation of critical sage grouse habitat.

\section{Forest Service}

Forest Service agrees to review and consider the recommendations in the Management Plan and Conservation Strategies for Sage Grouse in Montana prior to making any new decisions in sage grouse habitat.

1) Information and management recommendations in the Montana Sage Grouse Conservation Strategy will be considered and used during forest plan revisions for the Beaverhead-Deerlodge and Custer National Forests, and for the Lewis and Clark, Helena and Gallatin National Forest revisions (where applicable). These forest plans are scheduled for completion within the next ten years.

2) Use the Sage Grouse Conservation Strategy in large-scale and mid-scale assessments, and in project level analyses where sagebrush habitats are found in conjunction with sage grouse populations.

3) Continue to conduct standardized inventory and monitoring for both habitat and bird population tracking. Implement inventory and monitoring efforts, when funding is available, and do so in cooperation with Montana Fish, Wildlife and Parks, the Bureau of Land Management, or 
any other agency or non-governmental organization (NGO) or private landowner that can assist with such efforts.

4) Participate in local working groups with the objective of implementing the strategy.

5) Conduct and assist with administrative studies concerning the ecology of sage grouse in Montana; focus on areas where risks to populations and habitats are present, i.e., southwestern Montana. Participate in challenge cost share and other types of cooperative projects/agreements to accomplish administrative studies with partners such as Montana Fish, Wildlife and Parks, the Bureau of Land Management, universities or any other non-governmental organization (NGO).

6) Provide the appropriate level of annual support and funding, when available, for a statewide coordinator that will facilitate implementation of the Sage Grouse Strategy.

7) Continue to provide a Region 1 liaison for communication with the statewide coordinator, regional office, and forest and district staff.

8) Continue to execute and implement habitat restoration/improvement projects in cooperation and coordination with Montana Fish, Wildlife and Parks, the Bureau of Land Management, the U.S. Fish and Wildlife Service and other state or federal agencies and NGOs.

\section{Natural Resources Conservation Service (NRCS)}

The long-established working relationship between NRCS and private landowners presents the opportunity to effectively educate and advise the public about the importance of sagebrushgrassland and sage grouse conservation. NRCS is committed to assisting private landowners with proactive sagebrush-grassland conservation with the goal of preventing the sage grouse from being listed under the Endangered Species Act.

NRCS commits to the following actions to conserve sagebrush-grassland and sage grouse in Montana:

- Actively participate in the Montana Sage Grouse Working Group.

- Provide technical and financial assistance to private landowners for the restoration and management of native grasslands and shrublands.

- Faithfully follow NEPA, Threatened and Endangered Species, and Biology policy while providing technical and financial assistance to private landowners. This includes obtaining input from Montana Fish, Wildlife and Parks biologists as a part of planning and implementation of brush control projects. Management recommendations found in "Guidelines to Manage Sage Grouse Populations and Their Habitats in Montana", prepared by the Montana Sage Grouse Technical Committee, will be considered when assisting private landowners who wish to implement brush control actions. 
- Accelerate education efforts with private landowners about the importance of diverse plant and animal communities on native rangeland as well as life history and habitat requirements of sage grouse.

NRCS will provide technical and financial assistance for native grassland and shrubland conservation through the following programs:

Wildlife Habitat Incentives Program (WHIP):

Projects involving restoration and management of native prairie receive high priority for funding under WHIP. A number of existing contracts involve funding development of grazing systems intended to enhance biodiversity and to improve ground cover for ground-nesting birds.

Environmental Quality Incentives Program (EQIP):

Development of grazing systems to improve native grasslands and shrublands is eligible for technical and financial assistance under EQIP.

Wetlands Reserve Program (WRP):

Sagebrush-grasslands occurring within WRP contract acreage will be protected from conversion to other land uses. Grazing will only be allowed for habitat enhancement purposes.

Grassland Reserve Program (GRP):

Sagebrush-grasslands will be given priority points for enrollment in the GRP. The GRP will provide protection for these habitats ranging from 10-year contracts to permanent easements.

\section{Bureau of Land Management}

BLM will continue to collaborate with the Montana Sage Grouse Workgroup and implement actions to conserve sage grouse and other sagebrush-associated species. The agency plans to be an active participant in local work groups developing strategies for Plan implementation. If funding is available, BLM will contribute dollars to cost share an interagency sage grouse coordinator.

Over the past couple of years, earmarked funds have been appropriated for a Prairie/Sage Conservation Initiative. BLM has used the flexible funding source to support sage grouse surveys and habitat evaluations. If Initiative dollars are available, the agency will continue to collect valuable information about seasonal uses of habitat and other important information regarding sage-grouse habitats. BLM will also continue to pursue partnerships to acquire needed information.

Accurate vegetation cover information is lacking for much of the sagebrush across Montana. As funds allow, BLM will continue to work cooperatively with USFS, FWP, USGS EROS, University of Montana and others to reclassify GAP and improve the vegetation theme by delineating sagebrush density classes.

When making project decisions located in sage grouse habitat, objectives for sage grouse habitats and relevant information about sage grouse seasonal habitat needs will be considered when 
determining the desired resource condition. If specific issues regarding sage grouse are identified, applicable conservation actions or guidelines will be reviewed by interdisciplinary teams and considered in the decision-making process.

Application of the conservation actions is not mandatory or intended for actions in all sagebrush habitats. They should be viewed as recommended actions that have potential to maintain sagebrush habitats that are important to sage-grouse. Existing State, regional and local information about the condition and distribution of sage-grouse and their habitats should help managers decide when application of the guidelines is appropriate. Neither the objectives in the Plan nor the guidelines derived from them are intended to supersede NEPA or any other applicable laws or regulations.

BLM will view identified goals, objectives, and priority habitats for sage-grouse established in this Plan as the basis for developing strategies for implementing sage-grouse conservation actions on BLM managed lands.

Goals, objectives and priority habitats for sage-grouse and sagebrush associated species from this Plan will be included in at least one alternative during land use plan revisions if sage-grouse habitat is present in the planning area. 


\section{SECTION III: STATUS OF SAGE GROUSE IN MONTANA}

\section{GEOGRAPHIC DISTRIBUTION}

\section{North America}

Sage grouse (Centrocercus urophasianus) are native to the sagebrush steppe of western North America. Their distribution closely follows that of sagebrush, primarily big sagebrush (Artemisia tridentata) (Braun 1998). The species originally occupied portions of 16 states and three Canadian provinces. Sage grouse presently occur in 11 western states and two provinces, having disappeared from scattered areas around the periphery of its original range, including Arizona, British Columbia, Kansas, Nebraska, New Mexico, and Oklahoma. Much of the species' historical range has been greatly reduced by alteration or elimination of sagebrush habitat (Aldrich 1963).

\section{Montana}

Historical and current distribution of sage grouse (Fig. III-1) includes the eastern one-half and southwest corner of Montana. During the 1970s, sage grouse occurred in 39 counties in the state (Wallestad 1975) and still occur in 39 counties - a portion of Montana including about 11 million ha (27 million ac) of potential habitat. Distribution of sage grouse along a portion of the Hi-line -including Chouteau, Hill, Daniels, Roosevelt, and Richland counties -- includes small and scattered populations corresponding to the distribution of sagebrush. Liberty and Teton counties may have sage grouse, but sightings are unconfirmed (Graham Taylor, personal communication). The Milk River valley in Phillips County probably represents the northernmost limit of the distribution of big sagebrush. Sage grouse occurring north of the Milk River are primarily associated with silver sagebrush (A. cana) in habitats similar to those described for southeastern Alberta (Aldridge 1998).

\section{HABITAT USE IN MONTANA}

\section{Range of Movement}

In eastern Montana, where close interspersion of wintering, nesting, and brooding habitat rarely requires large seasonal movements, sage grouse are essentially nonmigratory (Eng and Schladweiler 1972); birds rarely move more than $17 \mathrm{~km}$ (10 mi). However, meeting yearlong habitat needs may require comparatively long seasonal movements between disjunct habitat patches.

Some sage grouse in southwestern Montana migrate between separate summer and winter areas (Martin 1970, Roscoe 2002), as similarly observed among sage grouse on the Snake River plains in Idaho, where 48-80 km (30-50 mi) may separate seasonal ranges (Dalke et al. 1963, Connelly et al. 1988). Migration also can be elevational and related to availability of succulent herbaceous vegetation during late summer and early fall. Ongoing research has documented such summer migratory movement of sage grouse from an area in eastern Idaho (including Crooked Creek, Lidy Flats, and Medicine Lodge) to Big Sheep Creek Basin in southwestern Beaverhead County, Montana (John W. Connelly, personal communication). Similar movement patterns were first reported during the early 1960 s. 


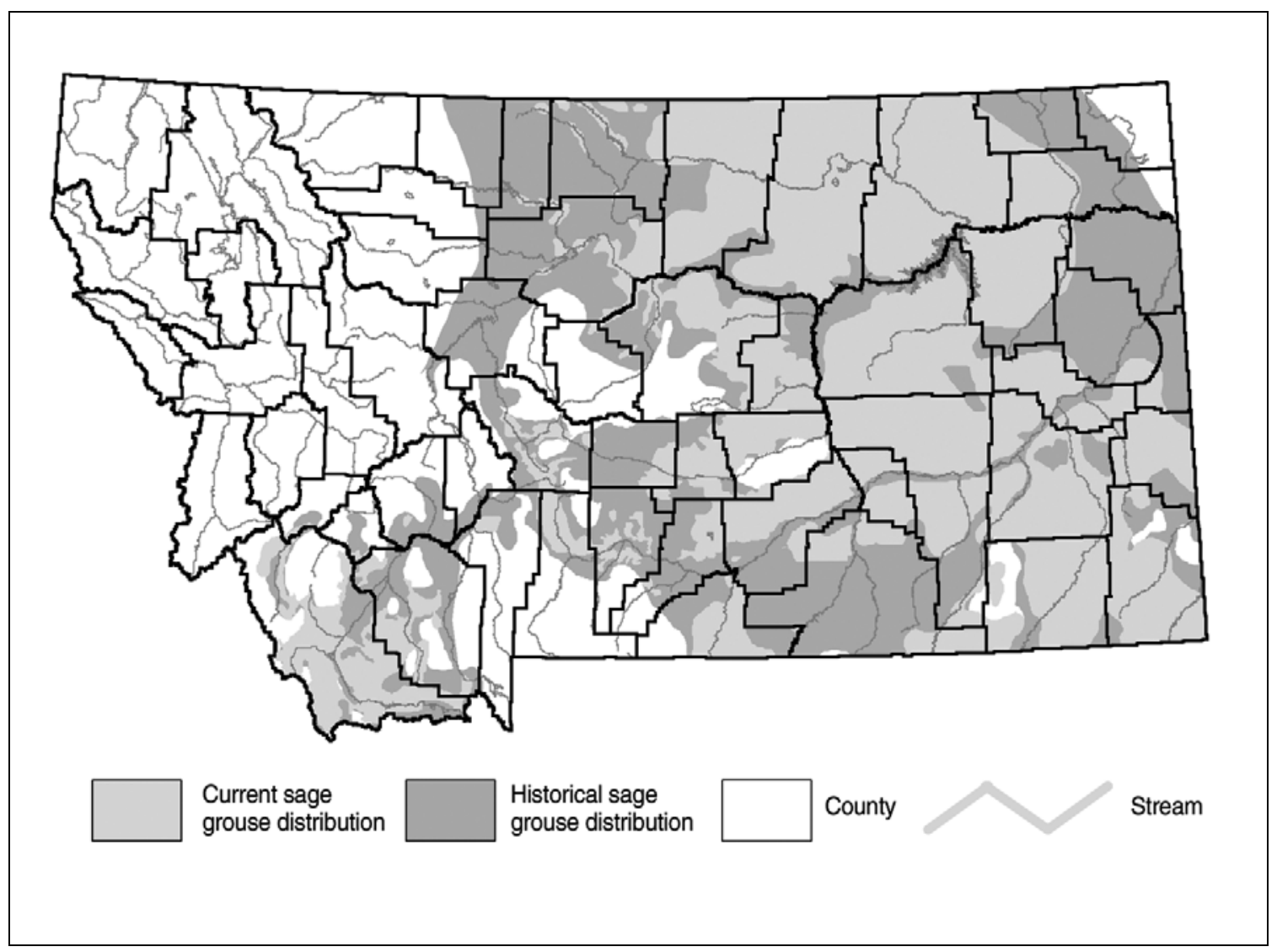

Figure III-1. Current and historical distribution of sage grouse in Montana. Map provided by MFWP Information Services.

\section{Breeding}

Wallestad (1975) found strutting grounds or "leks," where breeding actually occurs, to be key activity areas within wintering-nesting complexes. Leks most often consist of clearings surrounded by sagebrush cover. Such areas may include natural clearings, old burns, or ground cleared by homesteaders. In Idaho, sage grouse used recent burns or manmade clearings as leks only in the absence of natural openings (Connelly et al. 1981).

Wallestad and Schladweiler (1974) measured sagebrush at feeding and loafing sites of strutting cocks on the Yellow Water Triangle (YWT) in central Montana; 80 percent of these sites had a sagebrush canopy of 20-50 percent. Average sagebrush canopy overall was 32 percent (Eng and Schladweiler 1972). Slightly more than half of the total sagebrush plants measured at sites used by sage grouse occurred in the 6- to12-in $(15-30 \mathrm{~cm})$ height class.

Sage grouse invariably prefer sagebrush for nesting cover across their inhabited range (Patterson 1952, Klebenow 1969, Wallestad and Pyrah 1974, Sveum et al. 1998). Concealment was the basic requirement of nesting cover, and nest fate may be positively associated with tall grass cover and medium-height shrub cover collectively. Results from various studies in Montana and elsewhere 
documented a positive relationship between quality of nesting cover and nesting success (Wallestad and Pyrah 1974, DeLong et al. 1995, Sveum et al. 1998). Sage grouse most frequently selected sagebrush stands with a canopy of 15-31 percent (Klebenow 1969, Wallestad and Pyrah 1974).

Most nesting is believed to occur within $3 \mathrm{~km}$ ( $2 \mathrm{mi}$ ) of a lek in Montana and Colorado (Wallestad and Pyrah 1974, Braun et al. 1977) although Wakkinen et al. (1992) reported a random distribution of nests relative to lek location in Idaho. Sage grouse exhibit high nest-area fidelity but do not nest under the same bush from year to year, which might reduce the risk of nest predation (Fischer et al. 1993).

Nesting habitat for non-migratory sage grouse of central and eastern Montana overlapped with winter ranges. Overlapping of seasonal habitats often is not the case for grouse in southwestern Montana and Idaho, most of which are migratory. Connelly et al. (1988) suggested that tradition patterns have a greater influence on seasonal movements of sage grouse in Idaho than proximity of seasonal habitats.

\section{Summer-Fall}

Succulent forbs, the preferred food of sage grouse broods, provide key summer habitat for sage grouse (Klebenow 1969, Martin 1970, Peterson 1970a, Wallestad 1971). As palatability of forbs declines, sage grouse move to moist areas that still support succulent vegetation, including alfalfa fields, borrow pits, and other moist sites. During summers of high precipitation, sage grouse in Montana may remain widely distributed throughout the entire summer due to the wide distribution of succulent forbs in both time and space (Peterson 1970a). Elsewhere, movements during late summer may be elevational to mountain meadows where forbs remain succulent (Dalke et al. 1963, Connelly et al. 1988).

Sage grouse broods in central Montana preferred relatively open stands of sagebrush during summer, generally with a canopy ranging from 1-25 percent (Wallestad 1975). They also used borrow pits along roadsides throughout June and July. About 65 percent of all grouse observations during August and September were in alfalfa fields, greasewood in bottomlands, and borrow pits where succulent forbs remained relatively abundant. Increased use of higher density sagebrush in late September or October coincided with transition to a winter diet of sagebrush (Wallestad 1971).

Canopy of sagebrush stands at brood sites in southwest Montana and southern Idaho averaged 14 percent and 8.5 percent, respectively (Klebenow 1969, Martin 1970). However, adults used sites with relatively dense canopy (25 percent) during the same period (Martin 1970); relative to canopy height, big sagebrush ranged from 23-38 cm (9-15 in) at brood sites compared with 18-64 cm (7-25 in) at adult locations.

Males remained segregated from broods and hen flocks through summer and early fall. Because adult cocks used the same types of areas used by broods and hen flocks, segregation probably was more social than habitat-related. Most male flocks in the YWT used areas within 3-5 km (2-3 mi) of a lek. Flocks of broodless hens typically used areas of dense sagebrush throughout summer (Wallestad 1975). 
The importance of "free water" to sage grouse has not been widely documented or quantified (Connelly et al. 1990). Although some have suggested that distribution of open water is important to sage grouse, studies of radio-marked grouse in central Montana and southeastern Idaho failed to demonstrate the importance of open water to grouse, even during dry years (Wallestad 1971, Connelly et al. 1990). Grouse may redistribute themselves in response to a lack of succulent vegetation rather than to absence of open water.

\section{Winter}

Sage grouse generally select relatively tall and dense stands of sagebrush during winter. Winter ranges in eastern Montana, when snow depths ranged from 0 to 10 inches, included large expanses of dense ( $>20$ percent canopy) sagebrush with an average height of $25.4 \mathrm{~cm}$ (10 in) on relatively flat sites (Eng and Schladweiler 1972). This association with dense stands of sagebrush usually begins in September (Wallestad 1971) and continues through the breeding (Wallestad and Schladweiler 1974) and nesting (Wallestad and Pyrah 1974) seasons. No cocks were observed in areas having less than 10 percent canopy coverage. Sage grouse in Idaho immediately moved to sagebrush stands with taller shrub height when snow depth reached 33-38 cm (13-15 in) (Bean 1941).

\section{HABITAT STATUS}

Sage grouse are seemingly one of the more habitat-specific of North American grouse species (Aldrich 1963). More than 70 percent of the sagebrush-dominated rangeland that provides habitat has been converted to cropland in some states (Braun 1998).

As the Great Plains were homesteaded, sage grouse habitat deteriorated rapidly under intensive agriculture as land was heavily grazed or converted to crops. Sage grouse habitat had been fragmented or severely reduced in many areas by the 1930s, although some abandoned homesteads that reverted back to native rangeland during the 1930s eventually improved habitat for sage grouse (Wallestad 1975).

Sage grouse in several counties in central and southeastern Montana were perceived as abundant from about 1913 through the 1930s, even into the 1940's (anecdotal evidence) — noteworthy because much of that part of the state has remained in native rangeland up to the present time. In the 1950s, efforts to remove or alter stands of sagebrush became more efficient with the advent of the herbicide 2,4-D. By the early 1960s, elimination or reduction of sagebrush to increase grass production became a common practice on public as well as private rangeland (Martin 1970). Pyrah (1972) reported that adverse effects of treatment on sage grouse winter range were proportional to severity of treatment, e.g., partial kill strips are least severe whereas total kill is most severe. Treatments resulting in the least damage to sagebrush affected sage grouse use the least, and duration of the adverse effects was shortest.

The federal farm program encouraged conversion of private rangeland to cropland, or "sodbusting," which affected an untold amount of sagebrush steppe during the 1970s and 1980s. For example, Swenson et al. (1987) documented a significant habitat loss with subsequent decline in grouse numbers in the Shields Valley. A similar loss of habitat and decline in sage 
grouse populations had occurred in Meagher County during 1950-1970 as a result of both mechanical, e.g., plowing, and chemical treatment (Peterson 1970b).

Efforts to update estimates of sagebrush habitat currently occupied by sage grouse, based on evolving technology of geographical information systems (GIS), began in 1997. In 2001, FWP mapped sage grouse habitat distribution in cooperation with the Montana Natural Heritage Program and BLM, using the Montana GAP Land Cover types as a base layer (J. Herbert 2002, personal communication). FWP refined this distribution layer in May 2002 using the NRCS Legend for SILC-2 by removing land cover types, e.g., agricultural, wooded areas, and urban or developed lands, that likely would not provide habitat for sage grouse. This refinement generated an estimate of about 10.9 million ha (27 million acres) of potentially occupied sage grouse habitat, compared to the estimate of 4.4 million ha (10.9 million acres) reported by Wallestad (1975). The more recent estimate likely will be reduced as additional training data are acquired. Further separation can then be made of sagebrush communities at canopies of $<20$ percent from upland grassland and xeric shrub communities.

Implementation of the conservation plan includes monitoring and assessing habitat at multiple scales. The process is explained in Section VII.

\section{POPULATION DYNAMICS}

\section{Change Over Time}

Counts of males on leks during spring have been used since the mid-1950s to provide an index of relative size of breeding populations (Eng 1954, Wallestad 1975). Based on these spring counts from 1966 to 2001, sage grouse numbers probably increased, at least at a statewide scale, from the mid-1960s through 1973, when the average number of males/lek exceeded 30 and fluctuated about that level until reaching a peak in 1984 (Table III-1). The average number of males attending leks declined rather sharply from 1991 through 1996 and increased to a level above 30 males/lek during 2000 and 2001. These indexes of abundance represent leks that have been monitored for 10 or more consecutive years. All sage grouse leks in the state have not been located and the majority are not monitored on an annual basis. As a result, it is difficult to assess from spring lek counts, the effects of habitat loss and/or the fate of populations on total statewide numbers of sage grouse. However, when lek survey procedures described in Section VII are followed, monitoring male attendance on leks provides a reasonable index of relative change in abundance in response to prevailing environmental conditions over time. A monitoring protocol will be developed by FWP that will reflect trends in statewide abundance and distribution (Section VII, Research Needs).

Long-term harvest trends, based on post-hunt surveys of hunters, roughly track counts of males on leks (Fig. III-2), and when correlated with lek counts, provide insight as to long-term changes in sage grouse numbers at a broad scale. For example, years of high harvest generally followed a spring of high average numbers of males/lek. Conversely, years of relatively low harvest followed a spring of low numbers of males/lek. From about 1985 on, the harvest rates have declined significantly due to an apparent decline in sage grouse hunter numbers. 
Table III-1. Summary Of Long-Term Sage Grouse Lek Surveys In Montana, 1953-2003.1

\begin{tabular}{|c|c|c|c|}
\hline Year & No. leks surveyed & No. males & No. males/lek \\
\hline $1953-1961^{2}$ & $\leq 18$ & $91-537$ & $23.6-64.5$ \\
\hline 1962 & 19 & 613 & 32.3 \\
\hline 1963 & 20 & 931 & 46.6 \\
\hline 1964 & 20 & 867 & 43.4 \\
\hline 1965 & 18 & 569 & 31.6 \\
\hline 1966 & 21 & 458 & 21.8 \\
\hline 1967 & 21 & 436 & 20.8 \\
\hline 1968 & 23 & 567 & 24.7 \\
\hline 1969 & 30 & 848 & 28.3 \\
\hline 1970 & 29 & 840 & 29.0 \\
\hline 1971 & 28 & 899 & 32.1 \\
\hline 1972 & 36 & 1141 & 31.7 \\
\hline 1973 & 41 & 1382 & 33.7 \\
\hline 1974 & 45 & 1259 & 28.0 \\
\hline 1975 & 54 & 1329 & 24.6 \\
\hline 1976 & 53 & 1370 & 25.8 \\
\hline 1977 & 54 & 1607 & 29.8 \\
\hline 1978 & 58 & 1799 & 31.0 \\
\hline 1979 & 63 & 1834 & 29.1 \\
\hline 1980 & 69 & 2312 & 33.5 \\
\hline 1981 & 76 & 2208 & 29.1 \\
\hline 1982 & 79 & 2621 & 33.2 \\
\hline 1983 & 78 & 2747 & 35.2 \\
\hline 1984 & 77 & 2834 & 36.8 \\
\hline 1985 & 77 & 1615 & 21.0 \\
\hline 1986 & 77 & 1539 & 20.0 \\
\hline 1987 & 79 & 2008 & 25.4 \\
\hline 1988 & 77 & 2666 & 34.6 \\
\hline 1989 & 75 & 2304 & 30.7 \\
\hline 1990 & 80 & 2384 & 29.8 \\
\hline 1991 & 73 & 2439 & 33.4 \\
\hline 1992 & 74 & 1679 & 22.7 \\
\hline 1993 & 75 & 1475 & 19.7 \\
\hline 1994 & 73 & 1239 & 17.0 \\
\hline 1995 & 68 & 1276 & 18.8 \\
\hline 1996 & 67 & 1356 & 20.2 \\
\hline 1997 & 67 & 1390 & 20.7 \\
\hline 1998 & 67 & 1607 & 24.0 \\
\hline 1999 & 75 & 1860 & 24.8 \\
\hline 2000 & 78 & 2486 & 31.9 \\
\hline 2001 & 79 & 2518 & 31.9 \\
\hline 2002 & 77 & 1891 & 24.6 \\
\hline 2003 & 71 & 1966 & 27.7 \\
\hline
\end{tabular}

${ }^{1}$ Includes only leks that have been surveyed $\geq 10$ consecutive years.

2 Surveys were initiated in central and northeastern Montana (Regions 4 \& 6) during the 1950's and in southwest, southcentral, and southeastern Montana (Regions 3, 5 \& 7) in the 1960's. 


\section{Reproduction}

Fall productivity ratios were determined from examination of wings of grouse taken by hunters (Eng 1955, Table III-2). Findings from research in central Montana suggested that years with chick survival of $<3.60$ juveniles/hen were accompanied by population declines (Wallestad 1975). From a statewide perspective, however, chick survival was $\geq 3.60$ juveniles/hen in only four of 41 years (Table III-2). The median chick survival was 2.19 juveniles/hen during this 41 -year period. Years in which productivity was $\geq 2.19$ juveniles/hen were followed by increased numbers of males/lek the following spring 76 percent of the time (16 of 21 years, Tables III- 1 and III-2). If productivity was $<2.19$ juveniles/hen, there was a decrease in the lek count during the following spring 63 percent of the time (12 of 19 years). Thus, a threshold value for chick survival at a broad scale that would coincide with short-term population changes, reflected by numbers of males attending leks, probably would occur closer to the 41 year median of 2.19 juveniles/hen (Table III-2).

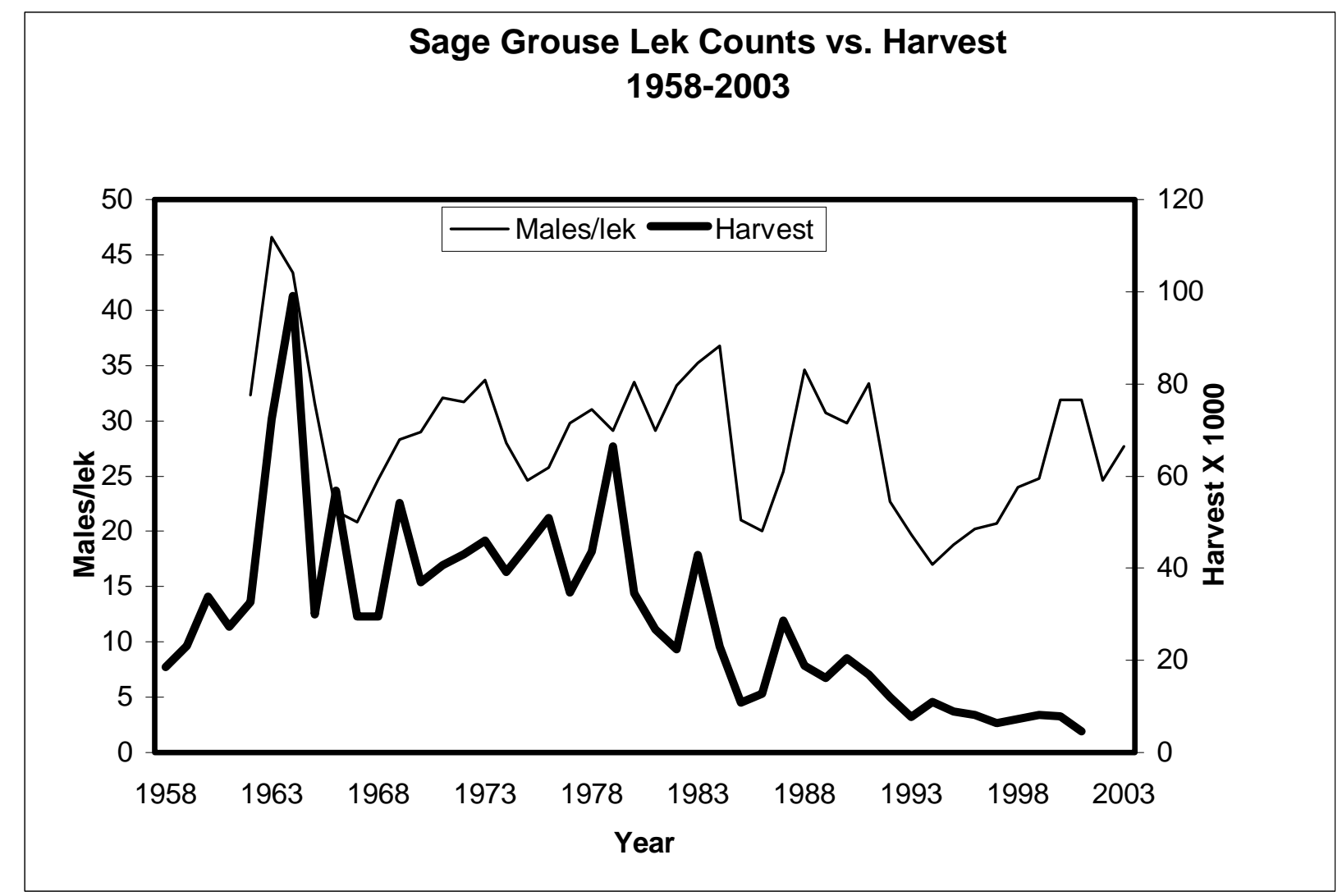

Figure III-2. Trends in sage grouse lek counts and harvest in Montana, 1958-2003.

The amount and timing of spring and summer rainfall affects annual production and population dynamics of sage grouse, causing short term fluctuations (i.e., $<10$ years) in sage grouse abundance (Eustace 2002). Wallestad and Watts (1973) identified weather-related factors that affected sage grouse productivity in central Montana. Their findings included:

1. No relationship between productivity and rainfall during the hatching period (peak second week of June); 
2. An inverse relationship between productivity and rainfall during the egg-laying period, i.e., rainfall $>2.5 \mathrm{~cm}(>1$ in) during the egg-laying period delayed the hatch resulting in poor productivity ( $<400$ juveniles: 100 females);

3. Total spring precipitation, as it potentially affects spring green-up of vegetation, further explained variations in productivity. Even with optimal rainfall during the egg-laying period, production was poor if total spring precipitation during the growing season was $<7.6 \mathrm{~cm}(<3$ in) from mid-April through mid-June; and,

4. No relationship was observed between temperature and productivity.

Nest success and early brood survival rates are considered some of the most significant vital rates influencing population dynamics of prairie grouse and other upland nesting species (Angelstam 1986, Peterson and Silvy 1996). In upland nesting ducks (Greenwood et al. 1995, Reynolds et al. 2001) and a variety of other bird species, nest predation increases (and nest success decreases) as the proportion of suitable nesting habitat on the landscape declines. The same pattern at the landscape level likely holds for sage grouse. At the nest-site level, nest success is highest where big sagebrush and a healthy understory of grasses and forbs provide critical residual nesting cover.

\section{Mortality}

Juvenile Mortality.- Juvenile mortality during the first few weeks after hatching is typically high, and nearly 40 percent of the young hatched in a given year die by early September (Wallestad 1975). Juvenile mortality rates can increase when drought reduces availability of insects and forbs for food, and important escape cover (herbaceous understory) is limited by poor growing conditions.

Over a 10-year period, Wallestad and Watts (1973) documented an average mortality rate of 56 percent in central Montana from the egg-laying period in April to the opening of the upland bird season in September. This included an average nest mortality of 30 percent and an average juvenile mortality to 1 September of 37 percent. Assuming a juvenile mortality rate from 1 September to 1 April (fall-winter) at least equal to that of yearling hens (65 percent) would yield an annual juvenile mortality rate of 85 percent.

Adult Mortality.- Survival rates for adult sage grouse are generally considered to be high (Connelly et al. 1993, Zablan 1993). Thus, population declines are usually not related to high levels of predation on adult birds (Connelly et al. 2000b).

Predation.- Both avian and mammalian predators take sage grouse. Bull snakes are also considered an effective nest predator in some areas. Predators destroyed 13 percent of known nests on the Yellow Water Triangle (Wallestad and Pyrah 1974). Nest predators included coyotes (Canis latrans), badgers (Taxidea taxis), and magpies (Pica pica). In the same study, nearly 40 percent of juvenile sage grouse succumbed to some form of mortality between hatching and early fall, although the proportion attributable to predation was unknown. Golden eagle (Aquila chrysaetos) and hawks, including the marsh (Circus cyaneus), Swainson's (Buteo swainsoni), red-tailed (B. jamaicensis), and rough-legged (B. lagopus) posed the most probable threat to young birds. Predation likely increases as a proximate cause of death under drought conditions. During a period of above average precipitation (Charlie Eustace, pers. communication), predators killed only 
three of about 70 radio-equipped adult sage grouse on the Yellow Water Triangle (Wallestad 1975). Adult hens are most vulnerable to predation during the nesting period, and low quality nesting cover increases the risk of predation. Adult males are most vulnerable during the spring breeding season while associated with the leks. Habitat alterations in the vicinity of leks, especially the construction of power poles or other perch sites for raptors, can affect male survival. Increased perch sites can also affect habitat security in brood rearing and wintering areas. Fragmented habitat may increase predation pressure on adult sage grouse by forcing birds into more marginal areas for foraging, travel, or roosting.

Dynamics of many predator populations are determined largely by abundance of their primary prey species, which are usually rodents or rabbits rather than grouse (Bump et al. 1947, Angelstam 1986, Myrberget 1988). Environmental conditions that influence changes in primary prey populations, e.g., rodent populations decline as a result of drought, can affect changes in foraging strategies of both mammalian and avian predators, thereby increasing encounters with grouse or grouse nests.

Hunting.- -Hunting results in direct mortality of sage grouse. It can be additive to other forms of mortality or, it can compensate for other forms of mortality with no net change in annual survival. Sage grouse harvest rates in Montana have declined over time (Figure III-2). Harvest declines are apparently a result of lower sage grouse hunter participation. FWP is in the process of developing an adaptive harvest strategy that will adjust harvest rates in response to changing sage grouse abundance levels (Appendix C).

Disease and Parasites. - West Nile virus was detected for the first time in sage grouse in Montana, Wyoming and Alberta during late summer 2003. Mosquitoes (especially Culex tarsalis) are thought to be the principal vectors of the disease and migratory birds, appear to be the major introductory host. The presence of a large sample of radio-instrumented sage grouse on several research study sites provided an opportunity to both detect mortalities and collect carcasses for submission to diagnostic labs. Preliminary evidence suggests variable rates of mortality among the study sites with 19 confirmed mortalities in Wyoming, 3 in Montana, and 5 in southeastern Alberta (B.Walker, 2003, pers. communication). Other confirmed mortalities were inconclusive from a diagnostic standpoint due to the decomposed condition of the carcass at the time of collection. Additional lab results and final analysis of the 2003 outbreak are pending. Future monitoring will be necessary to document the impact on population trends and the role of the virus in terms of observed mortality rates in subsequent years.

In addition to West Nile Virus, diseased birds have occasionally been observed in Montana, particularly in the vicinity of irrigation ditches and alfalfa fields (Wallestad 1975). Necropsy revealed coccidiosis. Outbreaks may occur in late July and August when sage grouse concentrate on areas where forbs remain succulent that include open water. The problem will generally subside with dispersal of birds to fall and winter ranges.

Simon (1940) described parasites commonly found in sage grouse in Wyoming. The incidence and infestation of all parasites except the protozoan Tritrichomonas was higher in young birds than in adults. Most sage grouse were infected with tapeworms but exhibited no serious ill effects. He 
concluded that two species of coccidia infect sage grouse: Eimeria angusta and E. centrocerci. Outbreaks of coccidiosis may locally decimate populations of sage grouse.

Table III-2. Sage Grouse Production From Statewide Collection of Wings From Hunter-Killed Birds, 19622002

\begin{tabular}{|c|c|c|c|c|c|c|}
\hline \multirow[b]{2}{*}{ Year } & \multicolumn{3}{|c|}{ Statewide } & \multicolumn{3}{|c|}{ South-central Montana $^{1}$} \\
\hline & $\begin{array}{l}\text { No. } \\
\text { Chicks }\end{array}$ & $\begin{array}{l}\text { No. } \\
\text { adult hens }\end{array}$ & $\begin{array}{l}\text { Chicks/ } \\
\text { adult hen }\end{array}$ & $\begin{array}{l}\text { No. } \\
\text { chicks }\end{array}$ & $\begin{array}{l}\text { No. } \\
\text { adult hens }\end{array}$ & $\begin{array}{l}\text { Chicks/ } \\
\text { hens }\end{array}$ \\
\hline 1962 & 962 & 305 & 3.04 & 219 & 66 & 3.32 \\
\hline 1963 & 1701 & 532 & 3.20 & 467 & 111 & 4.21 \\
\hline 1964 & 1267 & 798 & 1.59 & 385 & 207 & 1.86 \\
\hline 1965 & 1083 & 472 & 2.29 & 138 & 46 & 3.00 \\
\hline 1966 & 1020 & 420 & 2.43 & 96 & 59 & 1.63 \\
\hline 1967 & 822 & 289 & 2.84 & 75 & 30 & 2.50 \\
\hline 1968 & 1333 & 368 & 3.62 & 196 & 45 & 4.36 \\
\hline 1969 & 1263 & 520 & 2.43 & 73 & 39 & 1.87 \\
\hline 1970 & 1009 & 379 & 2.66 & 187 & 42 & 4.45 \\
\hline 1971 & 1431 & 499 & 2.87 & 233 & 55 & 4.24 \\
\hline 1972 & 1186 & 415 & 2.86 & 221 & 72 & 3.07 \\
\hline 1973 & 968 & 487 & 1.99 & 238 & 84 & 2.83 \\
\hline 1974 & 995 & 462 & 2.15 & 280 & 126 & 2.22 \\
\hline 1975 & 1187 & 518 & 2.29 & 474 & 163 & 2.91 \\
\hline 1976 & 1354 & 617 & 2.19 & 392 & 185 & 2.15 \\
\hline 1977 & 871 & 444 & 1.96 & 242 & 86 & 2.81 \\
\hline 1978 & 1257 & 404 & 3.11 & 339 & 103 & 3.29 \\
\hline 1979 & 1942 & 527 & 3.69 & 384 & 80 & 4.80 \\
\hline 1980 & 849 & 605 & 1.40 & 240 & 159 & 1.51 \\
\hline 1981 & 1118 & 499 & 2.24 & 282 & 125 & 2.26 \\
\hline 1982 & 797 & 398 & 2.00 & 240 & 117 & 2.05 \\
\hline 1983 & 1373 & 403 & 3.41 & 463 & 105 & 4.41 \\
\hline 1984 & 463 & 314 & 1.47 & 160 & 123 & 1.30 \\
\hline 1985 & 140 & 105 & 1.33 & 30 & 30 & 1.00 \\
\hline 1986 & 265 & 204 & 1.30 & 51 & 54 & 2.43 \\
\hline 1987 & 301 & 95 & 3.17 & 74 & 31 & 2.39 \\
\hline 1988 & 68 & 78 & 0.87 & 43 & 54 & 0.80 \\
\hline 1989 & 276 & 137 & 2.01 & 127 & 63 & 2.02 \\
\hline 1990 & 438 & 112 & 3.91 & 143 & 46 & 3.11 \\
\hline 1991 & 136 & 100 & 1.36 & 73 & 79 & 0.92 \\
\hline 1992 & 77 & 39 & 1.97 & 77 & 39 & 1.97 \\
\hline 1993 & 34 & 21 & 1.62 & 34 & 21 & 1.62 \\
\hline 1994 & 67 & 41 & 1.63 & 67 & 41 & 1.63 \\
\hline 1995 & 66 & 43 & 1.53 & 59 & 39 & 1.51 \\
\hline 1996 & 64 & 15 & 4.27 & 64 & 15 & 4.27 \\
\hline 1997 & 40 & 19 & 2.11 & 33 & 13 & 2.54 \\
\hline 1998 & 64 & 20 & 3.20 & 49 & 18 & 2.72 \\
\hline 1999 & 165 & 48 & 3.44 & 99 & 27 & 3.67 \\
\hline 2000 & 68 & 74 & 0.92 & 40 & 40 & 1.00 \\
\hline 2001 & 24 & 23 & 1.04 & 15 & 11 & 1.36 \\
\hline 2002 & 67 & 43 & 1.56 & 63 & 41 & 1.54 \\
\hline \multirow{2}{*}{\multicolumn{3}{|c|}{$\begin{array}{l}\text { Average chicks/hen } \\
\text { Median chicks/hen }\end{array}$}} & 2.32 & & & 2.53 \\
\hline & & & 2.19 & & & 2.39 \\
\hline
\end{tabular}

${ }^{1}$ Data are from FWP Region 5 for years from which a string of long-term statewide data was available. 


\section{POPULATION STATUS}

\section{Status Through the $20^{\text {th }}$ Century}

Anecdotal accounts suggest that sage grouse were declining throughout their range by the 1920s and 1930s (Braun 1998) although systematic surveys were lacking until the late 1950s.

Oyler-McCance et al. (2001) reported findings from a study of distribution of genetic variation among sage grouse populations across their inhabited range. Preliminary conclusions suggested that the only populations of sage grouse having low genetic diversity occur in the state of Washington.

Annual and biennial reports of the Fish and Game Commission during the first decade of the $20^{\text {th }}$ century expressed alarm about relative scarcity of sage grouse across Montana (C. D. Eustace, personal communication). A recommendation that the upland game bird season open on September 1 and close December 15 appeared in a report dated December 1900. Perceived effects of market and subsistence hunting on sage grouse and other upland game birds during that period concerned both policy-makers and sportsmen. Scarcity of big game throughout eastern Montana in the early 1900s could have exacerbated any adverse effect of market hunting on sage grouse. The federal Lacey Act, enacted in 1900, of which the intent was to address the impact of market hunting, prohibited interstate traffic of game animals.

From about 1913 through the 1930s, landowners, sportsmen, and agency personnel perceived an abundance of sage grouse in at least a portion of their inhabited range - most notably in Fergus, Petroleum, Rosebud, Garfield, Custer, and Powder River Counties. Limited information suggested that sage grouse again started to decline in about 1943 and continued downward for several years despite closed seasons during 1945-1951 (Martin and Pyrah 1971). Anecdotal information from Valley County suggests sage grouse numbers remained high during the 1940s. Harvest, and presumably grouse numbers, increased substantially during 1958-1964, a period over which daily bag limits varied from three to four birds.

\section{Status Throughout Montana}

Mountain Foothills Mixed Sagebrush Ecotype.-Sage grouse still occur in Meagher County but appear in a state of decline (G. Taylor, personal communication). Sage grouse in Park County declined significantly in the 1970s and 1980s in response to significant losses in sagebrush habitat - primarily through conversion to cropland (Swenson et al. 1987). Populations have recovered somewhat since the late 1980s and have remained relatively stable during the 1990s. In extreme southwest Montana (primarily Beaverhead and Madison counties), populations declined from those of the 1960s and 1970s during a period of large scale sagebrush manipulation programs (mostly spraying). A significant number of birds in southwest Montana breed in Idaho, move to higher elevation summer range in Montana, and migrate back to Idaho winter ranges, much of which has been converted to cropland. Populations now appear more stable, seemingly as a result of a reduction in sagebrush control programs, although some smaller declines have occurred in recent years in some locations. 
Wyoming Big Sagebrush-Silver Sagebrush Ecotype.--Sage grouse populations across northcentral Montana support relatively high numbers of birds with the exception of Chouteau and Hill counties. South Valley and Phillips counties support relatively high numbers of birds compared to portions of the respective counties lying north of the Milk River (A. Rosgaard, personal communication). Sage grouse occupying portions of the Hi-Line north of the Milk River are primarily associated with stands of silver sagebrush (Artemisia cana). An incomplete survey of leks in Valley County during spring 2000 yielded 1300 male sage grouse that included 250 males in a 36,000-ha block of south Valley (Gunderson 2001). Portions of north Valley have yet to be surveyed.

During spring 2000, 1600 male sage grouse were counted on leks in Fergus and northern Petroleum counties in central Montana (T. S. Stivers, personal communication).

In south-central Montana, sage grouse densities are highest in Big Horn, Carbon, Golden Valley, Musselshell, and Yellowstone counties (C.D. Eustace, personal communication). These counties contain fairly contiguous stands of sagebrush; leks are scattered randomly with an average spacing of 3.4 miles between leks. Remnant, or lower density, populations occur in Stillwater, Sweet Grass, and Wheatland counties, with widely spaced leks and sparse to highly fragmented sagebrush habitat.

Approximately 550 leks have been documented throughout southeastern Montana. Occupied habitats are scattered throughout the region with concentrations of leks in Rosebud, Garfield, Powder River, Custer, and Carter counties. Habitat loss has contributed to a long-term decline in grouse numbers throughout the region, which includes conversion of native range to cropland, energy development, and a variety of other factors.

The BLM has conducted additional lek surveys in conjunction with FWP since the early 1970s (K. Undlin, personal communication). During spring 2001, BLM completed aerial surveys in three areas of southeast Montana. Lek sites were chosen in collaboration with FWP. Several new leks were found, with the number of attending birds/lek ranging from 2 to 120 birds. Leks were considered inactive if native range had been converted to cropland. The majority of the active leks occupy larger blocks of sagebrush, primarily big sagebrush with seemingly fewer leks in silver sagebrush communities.

\section{CONSERVATION STATUS}

\section{Legal Status}

Sage grouse are not protected under the federal Migratory Bird Treaty Act, and thus, sage grouse are managed under state authority including the statutory authority to regulate harvest. Legislative mandate designates sage grouse as an upland game bird (87-2-101, MCA).

In 1870, the first regulations that affected hunting of prairie grouse in Montana, i.e., sage and sharp-tailed grouse, prohibited hunting from March 1 to August 15 (Montana Fish, Wildlife and Parks 1991). Hunting seasons for prairie grouse were shortened further by 1897 — August 15 to December 15-with a daily bag limit of 20 birds but no possession limit. Regulations in the early 1900 s became progressively more restrictive. By the 1930s and 1940s, hunting seasons for sage 
grouse were of short duration-generally about 1-4 days. The state of Montana prohibited sage grouse hunting during 1938 and 1945-1951. FWP has increased the area open to hunting of prairie grouse since 1960 and increased season length. Seasons were about 107 days in length by 1990, except the southwest portion in which seasons were of shorter duration. The 2003 sage grouse hunting season in Montana was from September 1 - November 1 with a 3-bird daily limit and a 6-bird possession limit.

The Natural Heritage Program, Montana State Library, has not listed sage grouse as a species of special concern although sage grouse currently are on a watch list of species that have not yet met "Special Concern" criteria (Roedel 1999). Although "Special Concern" designation would not change the legal status of sage grouse, it would raise the priority of the species in terms of effort committed to monitoring.

\section{Management in Montana}

Population Monitoring.- FWP monitors prairie grouse populations during spring, through census of displaying males on leks (Montana Fish, Wildlife and Parks 1991). Annual sage grouse production has been correlated to weather conditions, as reported by Eustace (2002) and

Wallestad and Watts (1973). Initial lek census included trend areas of approximately $50 \mathrm{mi}^{2}$ (130 $\mathrm{km}^{2}$ ) in size, from which complete aerial coverage was conducted during the breeding season (Martin and Pyrah 1971). Counts of maximum numbers of birds also were made on selected leks to provide year-to-year trends in relative abundance. Annual lek surveys do not currently provide the basis for annual harvest regulations because seasons are now set in advance of the period in which surveys are conducted (Montana Fish, Wildlife and Parks 1991). However, regional personnel have continued lek surveys to monitor long-term population trends, evaluate habitat projects, and refine understanding of sage grouse distribution in Montana.

Presently, FWP's yearly spring lek surveys include four trend areas (i.e., 1 in northeast, 2 in southeast, and 1 in south-central Montana). These long-term data sets have provided abundance indexes of breeding males from year to year, in their respective areas. Over the past three springs, FWP, with help from other agencies and individuals, has intensively inventoried sage grouse leks in areas where sage grouse are suspected to occur. This inventory work will continue until we are confident most or all leks have been documented. As a next step, FWP is working on developing a sampling method of leks in Montana that will provide long term abundance and distribution trend information on a statewide scale (Section VII, Research Needs).

The post-harvest telephone survey provides an estimate of harvest for all upland bird species, trend in hunter numbers, and number of birds by species taken by hunter. Wings from harvested sage grouse were used to estimate composition of the harvest by sex and age (Eng 1955), although collections discontinued on a statewide scale in mid-1980s. In south-central Montana, wing collections have continued, providing estimates of sex ratios of the breeding population and numbers of young/hen.

Habitat Acquisition and Protection.- FWP's habitat management initially emphasized preservation and maintenance of existing habitat that required investigation of proposed sagebrush control projects by agency personnel (Martin and Pyrah 1971). 
The 1987 Montana Legislature created a process and funding source for FWP to acquire conservation easements or purchase important wildlife habitat in Montana (87-1-241 and 242, MCA). The Habitat Montana program generated approximately \$5.6 million in the 1999-2000 biennium from an earmarked portion of license revenue and provides an innovative and effective tool to protect habitat at the state level.

The state-funded Upland Game Bird Habitat Enhancement Program (87-1-246, MCA) also was enacted in 1987 and amended in 1989, authorizing FWP to use funds for habitat improvement for upland game birds. A cooperative program has evolved to help private landowners implement habitat projects that benefit upland game birds. FWP provides technical assistance and reimbursement for seed, plants, materials, and practices conducted by the landowner. In addition to establishing nesting cover and food plots, these projects also include range improvements on private land, e.g., managed grazing systems. Since initiation of the program in 1989, emphasis on habitat improvement for upland game birds has increased, with approximately $\$ 5.4$ million spent on such projects through 1999.

In January 2000, FWP held an interest in 495,916 acres of private and public land for administering its wildlife programs. FWP has jurisdiction over 50,000 acres through conservation easements under the Habitat Montana program (S. Knapp, personal communication). Protection of shrub grassland has carried a high priority since 1993. Additionally, FWP has implemented grazing systems on more than 552,000 acres of rangeland under programs that include sagebrush steppe.

FWP establishes long-term vegetation monitoring sites on all WMAs and conservation easements where a grazing system has been implemented. FWP currently monitors 58 sites, and each site is monitored on a rotating basis once every 5 years. Numbers of sites monitored should increase as new lands are enrolled in the program. The effort will document the effectiveness of land management actions, i.e., livestock grazing systems, designed to improve range condition and trend. Monitoring addresses FWP's overall wildlife management goal of providing improved cover and forage for a diversity of bird and mammal species in a multiple-use system.

Research.- Research on sage grouse in Montana during the 1950s focused on monitoring strategies to determine population status and trend (Eng 1955). Efforts during the 1960s and 1970s addressed the effects of chemical and mechanical treatment of sagebrush on associated plant and animal communities (Martin 1970, Wallestad 1975) that included sage grouse and other sagebrush-dependent wildlife. These studies provided a biological basis for managing sagebrush steppe in the northern Great Plains and intermountain valleys.

Current research in eastern Montana includes determining the nature of interaction between population status of sage grouse, as expressed by estimated vital rates, and habitat condition (Moynahan et al. 2001). Another study in central Montana is designed to assess survivorship of sage grouse in both the presence and absence of hunting. A third project is assessing sage grouse demographics in areas of extreme southeastern Montana in relationship to on-going and proposed coal bed methane development. An ongoing effort in southwest Montana attempts to identify resident and migratory populations of sage grouse, key habitats, and movements, relevant to local conservation efforts (Roscoe 2002). 


\section{SECTION IV: HABITAT}

Healthy, properly functioning sagebrush communities support sage grouse and a variety of other native wildlife. Sagebrush communities in each of the sagebrush ecotypes (Section IV) are influenced by a variety of environmental variables. Among these variables are soil texture, moisture regime, past fire, past herbicide spraying, topography, grazing history, grazing accessibility, and recent weather pattern. The characteristics of vegetation at any particular site are the result of superimposed environmental variables. Close examination of a functional sagebrush community reveals these factors at work in the form of a patchwork of shrubs, grasses, and forbs of varying heights, canopy coverage, and species. Individual patches within the landscape can be measured at a microsite level, such as a nest site, or can be extended to include a broader scale that might be used to describe sage grouse wintering areas. Sage grouse have adapted to and require this naturally-occurring patchwork to meet yearlong survival and reproduction needs (Connelly et al. 2000b). Contiguous large blocks of healthy sagebrushgrassland are best suited for these purposes.

One or more habitat needs (e.g. nesting cover, brood rearing habitat, winter habitat, etc.) may restrict the abundance or productivity of sage grouse in a specific area at a specific time of year. These are referred to as limiting factors. Some limiting factors can be easily identified. In many parts of Montana, sagebrush distribution is a limiting factor for sage grouse, that is, where sagebrush is generally absent, there are no sage grouse. Within sage grouse habitats, drought, grazing management, predation, human disturbance, soils, and other environmental variables dictate what constitutes limiting factors.

This section describes sage grouse habitat preferences based on research in and around Montana. It is important to note that the vegetative preferences described, such as height and canopy coverage, are likely to occur as different sized patches in sagebrush-grassland communities. Specific measurements, such as grass canopy height at nest sites, do not imply a uniform pasturewide measurement but instead are a microsite measurement of vegetation at a specific site. For instance, within a functional sagebrush community, under average growing conditions, the mosaic of varying vegetative characteristics should provide for many potential nesting sites across the landscape. If not, nesting cover could be a limiting factor which would likely show up in the form of lower rates of nest success (Connelly et al. 2000b). Also, in some parts of Montana, vegetation may not be capable of achieving the described height or cover characteristics. Connelly et al. (2000b) suggested, "In all these cases, local biologists and range ecologists should develop height and cover requirements that are reasonable and ecologically defensible."

Our intention in describing these habitat preferences is to identify habitat needs of sage grouse and to help managers determine possible limiting factors associated with sagebrush communities. Sage grouse do not use their habitat randomly, but select habitat based on their needs at a particular time. Similarly, the habitat descriptors that follow cannot be applied randomly. Their application requires discretion and must recognize the natural patchwork of variability that exists in a functional sagebrush community and the potential of the site to produce and maintain woody shrub and herbaceous cover. 


\section{DESIRED CONDITION OF SEASONAL HABITATS}

\section{Breeding/Nesting Habitat}

Most habitat studies related to breeding emphasize that sage grouse select open areas surrounded by sagebrush as strutting grounds (Scott 1942, Patterson 1952:92, Schlatterer 1960, Gill 1965). Some have suggested that the lek is the hub of year-round activity (Eng and Schladweiler 1972, Wallestad and Pyrah 1974, Wallestad and Schladweiler 1974).

In central Montana, Wallestad and Schladweiler (1974) observed that 76 percent of movements of radio-equipped cocks during the breeding season occurred within $1.0 \mathrm{~km}(0.6 \mathrm{mi})$ of a lek; 80 percent of cock locations occurred in sagebrush stands with a 20- to 50-percent canopy cover that averaged 32 percent.

Martin (1970) and Gill (1965) found $\geq 80$ percent of nests to occur within $3.2 \mathrm{~km}$ (2.0 mi) of a lek in southwestern Montana and Colorado. From monitoring radio-equipped hens in central Montana, Wallestad and Pyrah (1974) found 68 percent of all nests within $2.4 \mathrm{~km}$ (1.5 mi) of a lek. Autenrieth (1976, unpublished data) observed that distance of nests from leks depended upon the proximity of leks to quality nesting habitat in Idaho. Among 306 nests located, 59 percent occurred within $3.2 \mathrm{~km}(2.0 \mathrm{mi})$ of a lek, 85 percent occurred within $6.4 \mathrm{~km} \mathrm{(4} \mathrm{mi),} \mathrm{and}$ 96 percent within $8.0 \mathrm{~km}(5.0 \mathrm{mi})$.

Wallestad and Pyrah (1974) compared sagebrush characteristics around 31 successful and 10 unsuccessful nests. Successful nests had greater $(P<0.05)$ sagebrush cover within $61 \mathrm{~cm}(24 \mathrm{in})$ of the nest within a $9.3-\mathrm{m}^{2}\left(100.1-\mathrm{ft}^{2}\right)$ plot around the nest and were located in stands of sagebrush with a higher average canopy coverage ( 27 percent) than those of unsuccessful nests (20 percent).

Shrub height of sagebrush most commonly used by nesting grouse ranges from $29-80 \mathrm{~cm}$ (11.531.0 in) (Table IV-1), and hens tend to nest under the tallest sagebrush plants within a stand (Keister and Willis 1986, Wakkinen 1990, Apa 1998).

A grass canopy-height $>18 \mathrm{~cm}(>7.2$ in) occurring in stands of sagebrush with a shrub height of 40-80 cm (16-31 in) apparently resulted in a lower rate of nest predation than stands with lower grass heights (Gregg et al. 1994, DeLong et al. 1995). Holloran (1999) reported that a grass canopy height of $12 \mathrm{~cm}$ (4.7 in) was adequate for successful nesting. Findings reported by Drut et al. (1994a) also suggest that an average perennial herbaceous canopy $\geq 8 \mathrm{~cm}$ (3.1 in) in height, a canopy cover of grasses $\geq 15$ percent, and a diversity of forbs during spring with a canopy $\geq 10$ percent improve nest success. Nest site vegetation measurements from a sample of radio-marked hens were collected in June and July 2003 on study sites in Phillips, Musselshell, and Powder River Counties. The nest site data has yet to be summarized. This cooperative effort between University of Montana, Montana State University, and FWP will be repeated in 2004.

Wallestad (1975) stated: "Nesting habitat in eastern Montana was synonymous with sage grouse wintering habitat and therefore considered as a wintering-nesting complex. Chances were good 
that any management practice that benefits or destroys one will affect the other in a similar manner."

Table IV-1. Habitat characteristics of associated sage grouse nest sites (from Connelly et al. 2000b and Heath et al. 1998).

\begin{tabular}{|c|c|c|c|c|c|}
\hline \multirow[b]{2}{*}{ State } & \multirow{2}{*}{$\begin{array}{l}\text { Sagebrush } \\
\text { Height }(\mathrm{cm})^{\mathrm{a}}\end{array}$} & \multicolumn{3}{|c|}{ Grass } & \multirow[b]{2}{*}{ Reference } \\
\hline & & Coverage $(\%)^{b}$ & Height $(\mathrm{cm})$ & Coverage $(\%)^{\mathrm{c}}$ & \\
\hline Colorado & $52(20.5$ in $)$ & & & & "Petersen 1980 \\
\hline Idaho & & 15 & & 4 & Kebenow 1969 \\
\hline Idaho & $58-79(23-31$ in $)$ & $23-38$ & & & Autenrieth 1981 \\
\hline Idaho & & & 18 (7 in) & $3-10$ & Wakkinen 1990 \\
\hline Idaho & & & $19-23(7.5-9$ in $)$ & $7-9$ & Connelly et al. 1991 \\
\hline Idaho & 61 (24 in) & & $22(9$ in $)$ & 30 & Fischer 1994 \\
\hline Idaho & & $15-32$ & $15-30(6-12$ in $)$ & & Klott et al. 1993 \\
\hline Idaho & 69 (27 in) & 19 & 34 (13 in) & 15 & Apa 1998 \\
\hline Montana & 40 (16 in) & 27 & & & Wallestad 1975 \\
\hline Oregon & 80 ( 31.5 in $)$ & 20 & & & Keister and Willis 1986 \\
\hline Oregon & & 24 & $14(5.5 \mathrm{in})$ & $9-32$ & Gregg 1991 \\
\hline Washington & & 20 & & 51 & Schroeder 1995 \\
\hline Washington & & 19 & & 32 & Sveum et al. 1998 \\
\hline Wyoming & 36 (14 in) & & & & Patterson 1952 \\
\hline Wyoming & 29 (11 in) & 24 & 15 (6 in) & 9 & Heath et al. 1977 \\
\hline Wyoming & 33 (13 in) & 19 & $17(6.5 \text { in })^{\mathrm{d}}$ & 8 & Heath et al. 1998 \\
\hline Wyoming & 31 (12 in) & 25 & 18 (7 in) & 5 & Holloran 1999 \\
\hline Wyoming & 33 (13 in) & 26 & 21 ( 8 in) & 11 & Lyon 2000 \\
\hline
\end{tabular}

${ }^{a}$ Mean height of nest bush.

b Mean canopy of the sagebrush surrounding the nest.

c Some coverage estimates may include both grasses and forbs.

${ }^{\mathrm{d}}$ Residual grass height averaged $11 \mathrm{~cm}$ (4 in)

\section{Brood Habitat}

Early brood rearing habitats may be relatively open stands of sagebrush, i.e., about 14 percent canopy cover for broods and 25 percent for adult sage grouse (Martin 1970, Wallestad 1971) with $>15$ percent canopy cover of grasses and forbs (Sveum et al. 1998).

Succulent forbs, a preferred food source for sage grouse broods, are a key component of summer habitat for sage grouse (Gill 1965, Savage 1968, Kelbenow 1969, Martin 1970, Wallestad 1971, Oakleaf 1971). Figure IV-1 (from Wallestad 1975:32) illustrates the distribution of 1599 sage grouse observations by cover type and sagebrush density at monthly intervals (June-October). Throughout June and July, common sagebrush (10-25 percent canopy coverage), scattered sagebrush (1-10 percent canopy cover), and borrow pits (roadside ditches) received 90 percent utilization by broods.

During August and September, about 65 percent of all grouse observations were recorded in bottomland types such as alfalfa fields and greasewood (Sarcobatus vermiculatus) bottoms (Wallestad 1975). 


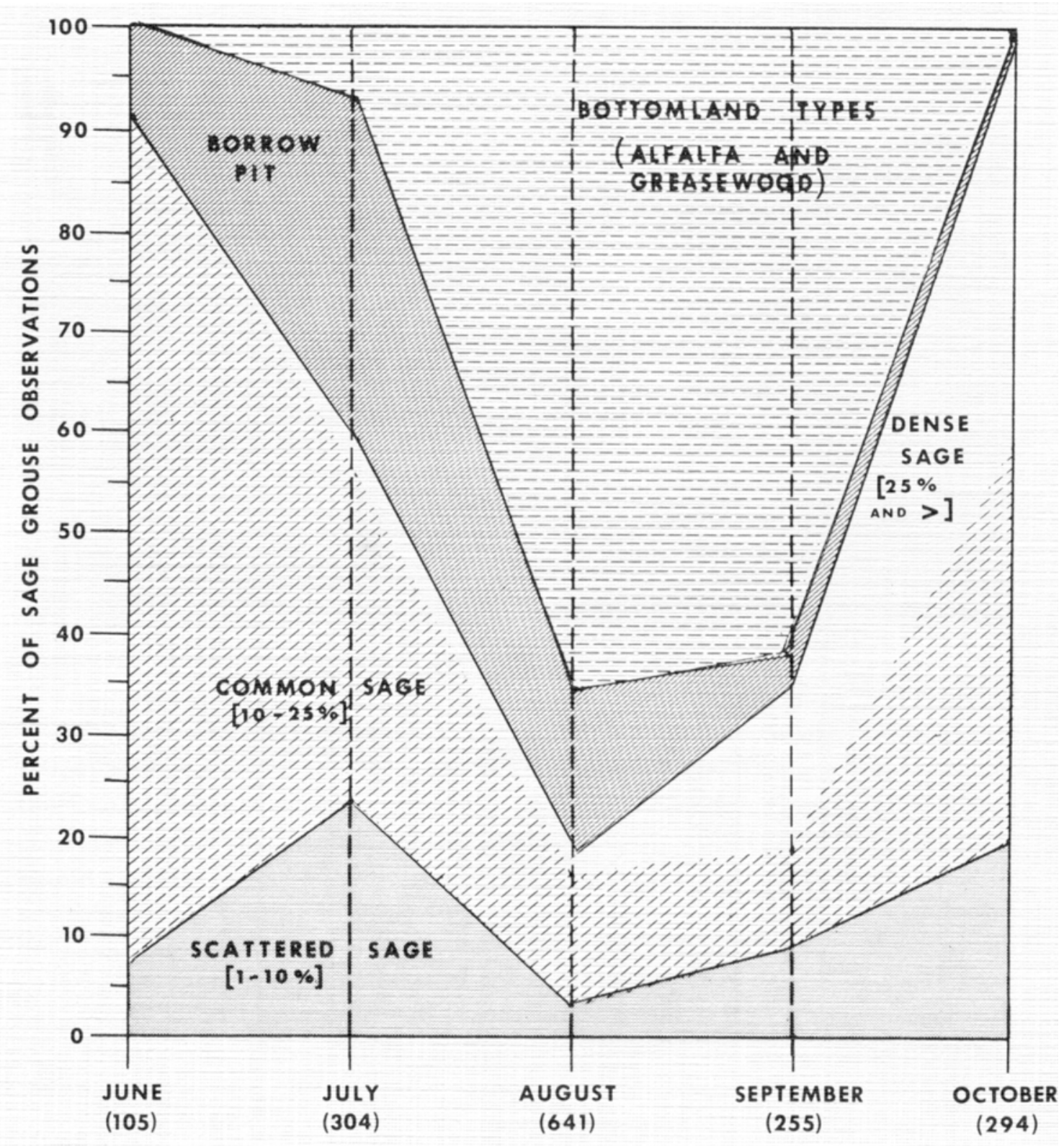

Figure IV-1. Distribution Of Sage Grouse In Central Montana By Cover Type And Sagebrush Density (From Wallestad 1975).

\section{Winter Habitat}

Sagebrush is the essential component of winter habitat. Sage grouse select winter use sites based on snow depth and topography, and snowfall can affect the amount and height of sagebrush available to grouse (Connelly 1982, Hupp and Braun 1989, Robertson 1991). 
Based on monitoring of radio-equipped grouse in Montana (Eng and Schladweiler 1972, Wallestad 1975), sage grouse mostly occupied sagebrush habitats with $>20$ percent canopy cover during winter. Robertson (1991) indicated that sage grouse used sagebrush habitats in southeast Idaho with an average canopy height of $46 \mathrm{~cm}$ (18.4 in); sage grouse selected areas with higher canopy cover of Wyoming big sagebrush (A.t. wyomingensis) in stands containing taller shrubs than they did random sites.

Approximately 10,320 ha $(25,500 \mathrm{ac})$ of sagebrush are available to sage grouse as winter range during a normal winter of $<25.4 \mathrm{~cm}(<10 \mathrm{in})$ snow depth in the Yellow Water Triangle, Montana. Snow depths exceeding $30.5 \mathrm{~cm}$ (12 in) restricted sage grouse to taller sagebrush stands on about 688 ha $(1,700 \mathrm{ac})$, or about 7 percent of the range available during a normal winter (Wallestad 1975). Beck (1975) also reported that sage grouse might be restricted to $<10$ percent of sagebrush steppe within a wintering area.

Assessing availability of sage grouse winter habitat on the basis of shrub structure is difficult without a measure of snow depth. Topographic criteria may be more useful for habitat assessment than measures of shrub structure because they do not require intensive vegetation sampling (Hupp and Braun 1989).

\section{MAJOR SAGEBRUSH ECOTYPES}

\section{Use of Ecotypes for Management}

We delineated sage grouse ecotypes to display geographic areas that have similar capabilities and potential for management of habitats occupied by sage grouse. Ecotypes are based on soils, climate, vegetation patterns, and sage grouse distribution. Sage grouse habitat and population objectives have been developed for multiple scales in Section I. Ecotypes described typically occur at "mid-scale" and are used in reference to objectives, although management of sage grouse habitats and populations will occur at various scales through implementation of this plan.

\section{Mountain Foothills Mixed Sagebrush}

Southwestern Segment.-The southwestern segment of the intermountain valley ecotype includes FWP Region 3, i.e., Beaverhead, Madison, and Park counties, and a portion of Regions 4 and 5, i.e., Sweetgrass and Meagher counties, and comprises two elements. The Beaverhead/Madison county complex occurs in high-mountain valleys and non-forested mountain slopes at elevations of $1676-2438 \mathrm{~m}$ (5500-8000 ft). Slope varies from nearly level to $45^{\circ}$ on some mountainsides. Mean annual precipitation is $38.6 \mathrm{~cm}$ (15.2 in). The Shields and Smith river complex (Park and Meagher counties) occurs at 1372-1981 m (4500-6500 ft), and slopes are predominantly near level or gentle. Mean annual precipitation is $41.4 \mathrm{~cm}$ (16.3 in) of which 40-45 percent falls during the growing season. Sites are typically dominated by mountain big sagebrush, but other species may be locally abundant. Idaho fescue (Festuca idahoensis) and bluebunch wheatgrass (Agropyron spicatum) represent the dominant grasses. Forbs are generally abundant.

South-central Segment.- The south-central segment includes portions of FWP Region 5, i.e., Carbon County, where low mean annual precipitation of $25.1 \mathrm{~cm}$ (9.9 in) and elevations greater than $1219 \mathrm{~m}(4000 \mathrm{ft})$ are typical. 


\section{Wyoming Big Sagebrush-Silver Sagebrush}

Southeast Segment.- Southeast Montana includes portions of FWP Regions 5 and 7 where sagebrush steppe occurs at elevations ranging from 607-1067 m (2000-3500 ft) on nearly level landscape or gentle slopes except for locally steep dissected river breaks. Stands of ponderosa pine are intermixed with prairie across the landscape. Major drainages include the Tongue, Powder, and lower Yellowstone rivers. Mean annual precipitation across this segment is $33.3 \mathrm{~cm}$ (13.1 in). Wyoming big sagebrush is found on fine textured soils, silver sagebrush is more abundant on medium textured, non-saline soils where moisture is more available, and greasewood is usually found on dense clay saline or alkaline soils. Dominant understory species include western wheatgrass (A. Smithii), prairie junegrass (Koleria cristata), needle-and-thread (Stipa comata), and green needlegrass $(S$. viridula).

Central Segment.-Central Montana includes portions of FWP Regions 4 and 5, i.e., Fergus, Chouteau, Petroleum, Musselshell, and Golden Valley counties. This segment is somewhat drier than southeastern Montana, with annual precipitation averaging about $32.0 \mathrm{~cm}$ (12.6 in) of which 40 percent falls during May and June. The shrub stratum at higher elevations is dominated by big sagebrush and by greasewood on bottomlands (Jorgensen 1979). Silver sagebrush is restricted to corridors along streams.

Northeast Segment.- - Northeastern Montana includes FWP Region 6, which consists of glaciated and unglaciated plains. Terraces, fans, and floodplains formed in glacial till characterize the landscape in the most northern reaches where short-grass prairie with scattered stands of silver sagebrush dominate, e.g., north of the Milk River. The southern portion of this segment, which lies north of the Missouri River, also supports stands of big sagebrush with silver sagebrush occurring along bottomlands. Large blocks of native range, dissected by many small ephemeral or intermittent streams, provide productive sage grouse habitat. Native grasses include blue grama (Bouteloua gracilis), needlegrasses (Stipa spp.), and wheatgrass (Agropyron spp.). Much of the extreme northeast corner of the state has been converted to agricultural cropping. Elevation ranges from 457-1341 m (1500-4400 ft). Most of northeast Montana receives mean annual precipitation of $25.4-38.1 \mathrm{~cm}(10-15 \mathrm{in})$ to as much as $43.2 \mathrm{~cm}$ (17 in) in the extreme northeast. Most precipitation falls during spring and summer, with 20-30 percent occurring as snow during winter. 


\section{SECTION V: PROBLEMS CONFRONTING THE SPECIES}

Presently, Montana supports relatively large and sustainable sage grouse populations compared to some other parts of their range (Section III). Generally speaking, management prescriptions that have retained native characteristics of the sagebrush-grasslands have continued to support Montana's sage grouse populations. Sage grouse conservation in Montana is not a "recovery effort" as much as it is a "conservation maintenance effort." The SGWG identified a set of risks including programs, practices, and activities that can have long-term adverse effects on sagebrush habitat and/or sage grouse productivity and survival. Across the sage grouse's range, long-term declines and reductions in sage grouse distribution have primarily been the result of habitat fragmentation, degradation, and conversion (Connelly and Braun 1997, Schroeder et al. 2000). Our first line of conservation, therefore, is to maintain habitat productivity that results in sustainable and productive sage grouse populations.

Biologically, mortality due to managed hunting and predation does not present a long-term threat to sage grouse in Montana, given the species' distribution and status (Section III). That is, because Montana's sagebrush-grasslands are relatively intact and functional, sage grouse maintain productive populations across most of their historic range. As with other game species in Montana, sage grouse have supported a certain level of managed hunting and predation without compromising their long-term viability. However, if one or more population segments showed a long-term decline, impacts of hunting and predation would need to be evaluated along with habitat factors. For further discussion on hunting and predation see Section III, Mortality and Section VI and for information on adaptive harvest management see the Appendix.

\section{RISKS IN GENERAL}

\section{Habitat: Loss, Fragmentation, Degradation}

Conversion of native sagebrush-grassland to cropland or nonnative pasture.- Plowing and introduction of cultivated crops or other nonnative species for pasture have been implicated as a major factor leading to the long-term loss of sage grouse habitat. Plowing of sagebrush steppe may be more detrimental to sage grouse than chemical treatment because it affects gentle terrain on which sage grouse winter, and sagebrush is not likely to recover as a result of continuous cultivation. Swenson et al. (1987) reported a decline in the population index for grouse of 74 percent in south-central Montana following a net conversion of 16 percent of their study area to cropland. The cumulative effect of continued spraying and plowing over a series of years on a sage grouse population in Meagher County resulted in a reduction of available sagebrush habitat by 49 percent, a significant reduction in numbers of grouse, and the elimination of five leks (Peterson 1970b). Upland waterfowl nesting studies in Montana, Canada, and the Dakotas have reported a strong positive correlation between nest survival and grassland habitat block size (Ball et al. 1995, Greenwood et al. 1995, Reynolds et al. 2001). These researchers reported that as habitats become more fragmented by conversion to cropland, nests are more susceptible to predation, which significantly reduces productivity. This pattern likely holds true as well for other upland-nesting birds, including sage grouse. 
Encroachment through site development.- Siting of structures for oil and gas development, electrical generation and transmission, and other infrastructure can decrease the habitat base for sage grouse. Fence wires and power poles can either directly contribute to mortality or increase the risk of predation by providing perches (Borell 1939, Aldridge 1998).

In light of significant loss of sagebrush-grassland, juxtaposition of the remaining sagebrush steppe and rangeland treatments used at a scale and intensity under which sagebrush reduction might occur, also can adversely affect local populations of sage grouse over the long term (Braun 1998, Schroeder et al. 2000). Patches of sagebrush separated from larger patches of sagebrushgrassland might reduce the segments' capacity to produce sage grouse.

Grazing and herbivory.-Continuous use by domestic livestock and wild ungulates might not leave suitable residual cover or maintain the site potential for seasonal or yearlong habitats used by sage grouse. Grazing affects sagebrush-grassland habitat through its direct effect on plants and indirect effect on soil and microclimate. Jorgensen (1979) assessed the effects of long-term grazing on several habitat types in central Montana. Through literature review, Beck and Mitchell (2000) identified both positive and negative direct effects of livestock grazing on sage grouse habitat. Light to moderate grazing by cattle or managed grazing systems can improve both quantity and quality of summer forage, i.e., forbs, for sage grouse. Heavy to severe overgrazing reduces habitat quality, which may lead to increased nest predation or nest desertion, or may pre-empt use of a site by grouse altogether (Beck and Mitchell 2000). Residual grass cover following grazing is essential to maintaining the quality of nesting habitat.

Rangeland treatments. - Both burning and spraying can reduce or adversely alter the composition of herbaceous understory and shrub canopy (Connelly et al. 2000b, Wambolt et al. 2002) Risks to sage grouse from fire include loss of sagebrush canopy on breeding, brood rearing, and winter habitats.

Big sagebrush stands do not require disturbances such as fire or grazing to be perpetuated (Beetle and Johnson 1982, Peterson 1995, Welch in preparation). Although many big sagebrush stands have the gross appearance of being even-aged or decadent, close observation and age sampling often reveals a diverse age structure (Peterson 1995). Long-lived sagebrush stands actually have more opportunity for mixed age classes (Welch in preparation). Depending on a number of factors including soils, vegetation, available moisture, and size of burn, sagebrush recovery from fire can easily require 30 years or more (Welch in preparation). Sagebrush species and subspecies that regenerate from seed, e.g., Wyoming and basin big sagebrush, often are eliminated if the site treated by prescribed fire is too large. Species that resprout from crowns and roots, e.g., silver sagebrush, three-tip sagebrush, and some forms of mountain big sagebrush, can re-establish if the fire intensity is not too high. Scientific literature on the effects of fire supports an argument against the use of fire to manage sage grouse habitats (Connelly et al. 2000a, Wambolt et al. 2002).

Timing and scale of herbicide application reduces sagebrush and/or the forb component and could reduce production and survival of grouse through reduced nutritional level and increased predation. Indirect effects also are worth considering. For example, persistent application of herbicides can alter composition and diversity of plant species significantly enough to affect availability and quality of the insect component. Any significant loss of a food source critical to 
early survival of chicks also may have a long-term effect on populations (Potts 1986). Available literature on the effects of herbicide application on sage grouse is almost entirely limited to the effects of sagebrush reduction or removal.

Human activities.- Recreation or commercial activities, such as those related to energy facilities and high-volume traffic on roads, can adversely affect breeding and reproduction through disturbance (Mattise 1995, Trombulak and Frissell 2000) and reduce habitat quality through the spread of noxious weeds. Noxious weeds and other undesirable invading plants, e.g., cheatgrass, decrease forage and/or herbaceous cover for ground-nesting birds (Jones and Hungerford 1972).

\section{Physical Threats to Sage Grouse}

Weather.- One of the primary factors affecting short term changes in sage grouse abundance is weather. Extreme weather conditions, especially during the nesting and brood rearing periods, can result in complete losses in productivity. Weather patterns, such as drought, that last multiple years can result in significant temporary population declines.

Disease.- Disease and parasites, such as coccidiosis, can locally increase sage grouse mortality, although this is a minor concern. West Nile virus has been documented to kill sage grouse in Wyoming and Montana. Tests for West Nile require samples from birds that have died within 24-48 hours of sampling, which is difficult to achieve without intensive monitoring. Radio collared sage grouse from ongoing studies have been closely monitored during late summer 2003 to determine possible impacts of the virus on sage grouse. Preliminary evidence suggests variable rates of mortality among the study sites with 19 confirmed mortalities in Wyoming, 3 in Montana, and 5 in southeastern Alberta (B.Walker, 2003, pers. communication). Other confirmed mortalities were inconclusive from a diagnostic standpoint due to the decomposed condition of the carcass at the time of collection. Additional lab results and final analysis of the 2003 outbreak are pending. Future monitoring will be necessary to document the impact on population trends and the role of the virus in terms of observed mortality rates in subsequent years.

Application of insecticides.- - Reducing insect supplies during early brood rearing can contribute to mortality of chicks, and use of chemicals could physiologically predispose sage grouse to mortality. Approximately 9 million ha $\left(35,000 \mathrm{mi}^{2}\right)$ of western rangelands were treated to control grasshoppers from 1985 to 1990 (Johnson and Boyce 1990), much of which was commonly used by sage grouse for nesting. Grasshoppers and other insects are key items in the diet of sage grouse chicks and are essential to early growth and development (Klebenow and Gray 1968, Peterson 1970a, Johnson and Boyce 1990). Blus et al. (1989) documented a high potential for direct mortality of sage grouse following application of organophosphorus insecticides in southeastern Idaho.

Other factors. - Human activities, such as watching grouse on leks, flushing birds during nesting/brood rearing by mechanized vehicles, or dog training, could lead to mortality from predation, accidents, or other proximal causes. 


\section{RISKS BY ECOTYPES}

\section{Mountain Foothills Mixed Sagebrush}

Southwest Segment.- Human population growth and associated development continue to reduce and fragment sage grouse habitat in southwest Montana. Conversion of native range to crops may cause a further reduction of sage grouse populations in some areas. Sagebrush manipulation, resulting in shrub species conversion, i.e., mountain big sagebrush to three-tipped sagebrush, and degraded sage grouse habitats continues in some areas of the segment. Overgrazing and wildfire may pose some additional risk as would hunting and predation if other factors resulted in large population declines.

South-central Segment.- - With the exception of Billings and intensive agriculture along the Yellowstone River along the northern edge, a low human density characterizes most of this segment, and we do not anticipate any significant expansion to the south. Sagebrush manipulation, overgrazing, and wildfire pose the greatest risk to sage grouse. Hunting and predation may pose some additional risk if, as a result of other factors, there were large population declines.

\section{Wyoming Big Sagebrush-Silver Sagebrush}

Southeast Segment.- The southeast segment is sparsely populated with people, and we do not anticipate any significant expansion. Sagebrush manipulation, overgrazing, wildfire, and energy development, e.g., coal bed methane, pose the greatest risk to sage grouse. Hunting and predation may pose some additional risk if, as a result of other factors, there were large population declines.

Central Montana Segment.- With the exception of Billings and intensive agriculture along the Yellowstone River along the southern edge, a low human density characterizes most of this segment and we anticipate no significant expansion to the north. Sagebrush manipulation, overgrazing, energy development, and wildfire may pose the greatest risk to sage grouse. Hunting and predation may pose some additional risk if, as a result of other factors, there were large population declines.

Northeast Segment. - This segment has comparatively low human population density, and we do not anticipate any expansion. Conversion of native sod to cropland poses the greatest risk to sage grouse throughout of this segment. Sagebrush manipulation, overgrazing, and increased energy development also pose some risk to sage grouse. In light of large population declines, hunting and predation also might pose some additional risk. 


\section{SECTION VI: CONSERVATION ACTIONS}

\section{ADAPTING WAFWA GUIDELINES TO MONTANA SAGEBRUSH HABITATS}

The Western Association of Fish and Wildlife Agencies (WAFWA) charged a team of biologists to update sage grouse habitat management guidelines (Braun et al. 1977). The updated guidelines (Connelly et al. 2000b) were written to pre-empt, reverse, or mitigate population declines and maintain viable populations of sage grouse.

The WAFWA guidelines, based on a compilation of literature, describe site conditions required to meet seasonal habitat needs of sage grouse. However, the guidelines do not describe a desired condition for habitat on a landscape scale, plant composition, and structural characteristics across all sagebrush communities in which sage grouse occur. For that reason, some federal agencies are currently developing a strategy to assess landscapes, meet WAFWA guidelines for sage grouse, support communities of other animals that use sagebrush habitats, and prescribe management strategies at multiple scales.

The guidelines (Connelly et al. 2000b) acknowledge information gaps and regional variation in habitat structure and composition and suggest that local biologists apply quantitative data from habitat and population monitoring to address local conditions. The Montana SGWG has considered the WAFWA guidelines as a technical reference to develop conservation strategies that will maintain or enhance sage grouse populations and habitat in Montana.

Federal agencies have agreed to consider the sage grouse guidelines when authorizing any activities or revising land use and activity plans in areas where sage grouse are known to occur. An Interagency Steering Committee representing BLM and USFS has been formed to address sagebrush habitat and conservation planning issues across federal and state boundaries and develop a consistent approach for incorporating conservation needs into federal land management plans.

Adoption of resource objectives or management guidelines will require an analysis under the NEPA process.

\section{CONSERVATION ISSUES AND ACTIONS}

An issue is any unresolved conflict that has the potential to affect the biological, ecological, social, or economic environment, including wildlife and habitats. This section describes relevant issues identified by the public and the SGWG. Conservation actions that address each issue include measures or "tools" to resolve or minimize conflicts and meet objectives for sage grouse habitats and populations. We discussed and adopted the conservation actions that appear in this section to establish a framework for making decisions and offer a range of options to address specific issues. Conservation actions developed at a statewide scale will serve as a template to evaluate regional issues through local workgroups.

Considered to be of equal importance, the issues are listed alphabetically: fire, harvest management, livestock grazing management, noxious weed management, mining and energy development, outreach, education, and implementation, power lines and generation facilities, 
predation, recreational disturbance of sage grouse, roads and motorized vehicles, vegetation, other wildlife.

\section{Fire Management}

Fire has always been present in sagebrush communities. The benefits and detriments to sage grouse habitats and relative frequency of fire often are subjects of disagreement. Fire has been a factor in the loss of mature sagebrush habitat and affects sagebrush communities differently depending on the species of sagebrush. Fire management actions are divided into two categories: suppression of wildfires and prescribed fire. Both wild and prescribed fires can have cumulative effects on sagebrush habitat and the species that depend on it.

Prescribed fires are planned events with specific objectives; however, changes and variation in conditions at the site can change the actual outcome. Use of prescribed fire in the sagebrush community can result in a net loss of sagebrush and is of concern to those desiring to maintain a mature sagebrush community. Some private landowners and public land managers consider fire an effective tool to manage sagebrush stands with dense sagebrush cover and suppressed herbaceous cover. Some stakeholders hold that prescribed burning reduces the risk of wildfire and other factors that otherwise might adversely affect the sagebrush community. Yet others are concerned about both spatial and temporal effects that fire can have on wildlife that depend on the sagebrush community.

Wildfires are less predictable and unplanned, and they have the most significant effect in the densest sagebrush. Suppression actions can serve to either protect sagebrush communities or destroy habitat. The highest suppression priorities are human life, community protection, and resource considerations. Thus, prior knowledge of important sage grouse habitat is necessary if consideration is to be given in light of higher priorities.

\begin{tabular}{|c|c|c|}
\hline \multicolumn{3}{|c|}{$\begin{array}{l}\text { How can we minimize impacts of wildfire or prescribed fire on sage grouse } \\
\text { habitat? }\end{array}$} \\
\hline Goal & Issue & Conservation Actions \\
\hline $\begin{array}{l}\text { Manage prescribed fire } \\
\text { in sagebrush habitats to } \\
\text { result in no long-term } \\
\text { net loss. }\end{array}$ & $\begin{array}{l}\text { Reduction of sagebrush } \\
\text { by prescribed fire. }\end{array}$ & $\begin{array}{l}\text { 1) Sites should not be burned unless: } \\
\text { a) biological and physical limitations of the } \\
\text { site and impact on sage grouse are } \\
\text { identified and considered, including } \\
\text { moisture regimes, soil texture, seed } \\
\text { sources, and sagebrush recovery time, } \\
\text { b) management objectives for the site, } \\
\text { including those for wildlife, are clearly } \\
\text { defined, } \\
\text { c) potential for weed invasion and } \\
\text { successional trends are well understood, } \\
\text { and }\end{array}$ \\
\hline
\end{tabular}




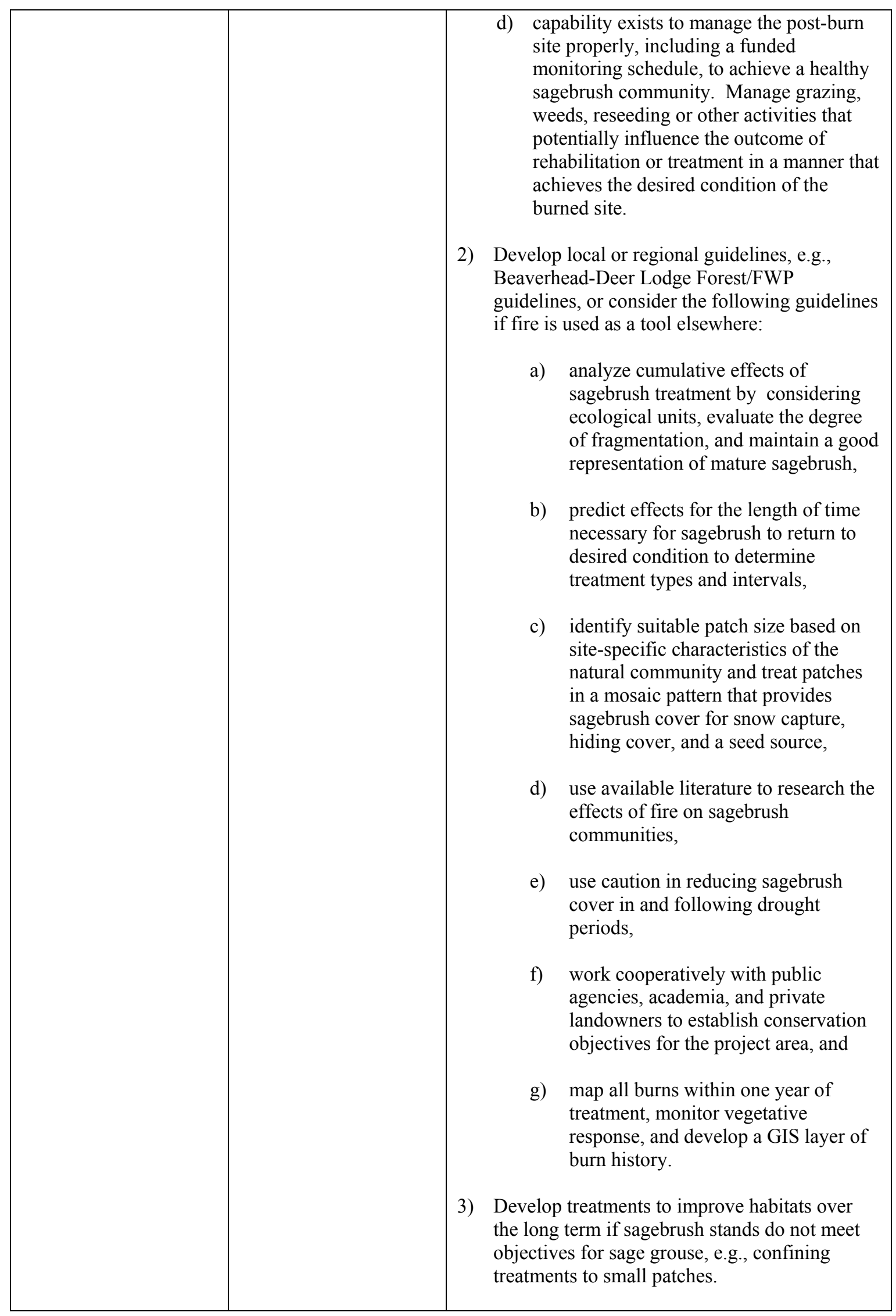




\begin{tabular}{|c|c|c|c|}
\hline & & 6) & $\begin{array}{l}\text { Consider both mechanical treatments and } \\
\text { prescribed fire if actions are required to remove } \\
\text { conifers that encroach on sage grouse habitat. } \\
\text { Sage grouse habitat needs, ecological } \\
\text { considerations, and availability of forest } \\
\text { habitats should influence the preferred method. } \\
\text { Avoid treatments to sage grouse habitat in } \\
\text { areas that are susceptible to invasion by } \\
\text { cheatgrass or other invasive plant species. } \\
\text { Treatment will be accompanied by restoration, } \\
\text { and reseeding if necessary, to re-establish } \\
\text { native vegetation. } \\
\text { Protect sagebrush along riparian zones, } \\
\text { meadows, lakebeds, and farmlands that include } \\
\text { important sage grouse habitat: } \\
\text { a) winter habitat, } \\
\text { b) breeding habitat, and } \\
\text { c) nesting habitat. } \\
\text { Wash vehicles and heavy equipment for fires } \\
\text { introduction of noxious weeds. }\end{array}$ \\
\hline $\begin{array}{l}\text { Manage wildfire in } \\
\text { sagebrush habitats to } \\
\text { result in no long-term } \\
\text { net loss. }\end{array}$ & $\begin{array}{l}\text { Reduction of sagebrush } \\
\text { by wildfire. }\end{array}$ & $\begin{array}{l}\text { 3) } \\
\text { 4) }\end{array}$ & $\begin{array}{l}\text { Schedule annual coordination meetings-with } \\
\text { appropriate resource staff including fire } \\
\text { specialists, wildlife biologists, and range } \\
\text { ecologists - to incorporate new sage grouse } \\
\text { habitat and other wildlife habitat information } \\
\text { needed to set wildfire suppression priorities } \\
\text { related to resources. Distribute updates to fire } \\
\text { dispatchers for initial attack planning. } \\
\text { Identify the location of known sage grouse } \\
\text { habitat and other wildlife habitats of concern, } \\
\text { e.g., latitude and longitude with a polygon and } \\
\text { radius, to avoid disturbance or degradation by } \\
\text { temporary facilities, e.g., fire camps, staging } \\
\text { areas, and helibases. } \\
\text { Incorporate known sage grouse habitat } \\
\text { information into each Wildfire Situation } \\
\text { Analysis to help determine appropriate } \\
\text { suppression plans and prioritize multiple fires. } \\
\text { Retain unburned areas of sage grouse habitat, } \\
\text { e.g., interior islands and patches between roads } \\
\text { and fire perimeter, unless compelling safety, } \\
\text { resource protection, or control objectives are at } \\
\text { risk. }\end{array}$ \\
\hline
\end{tabular}




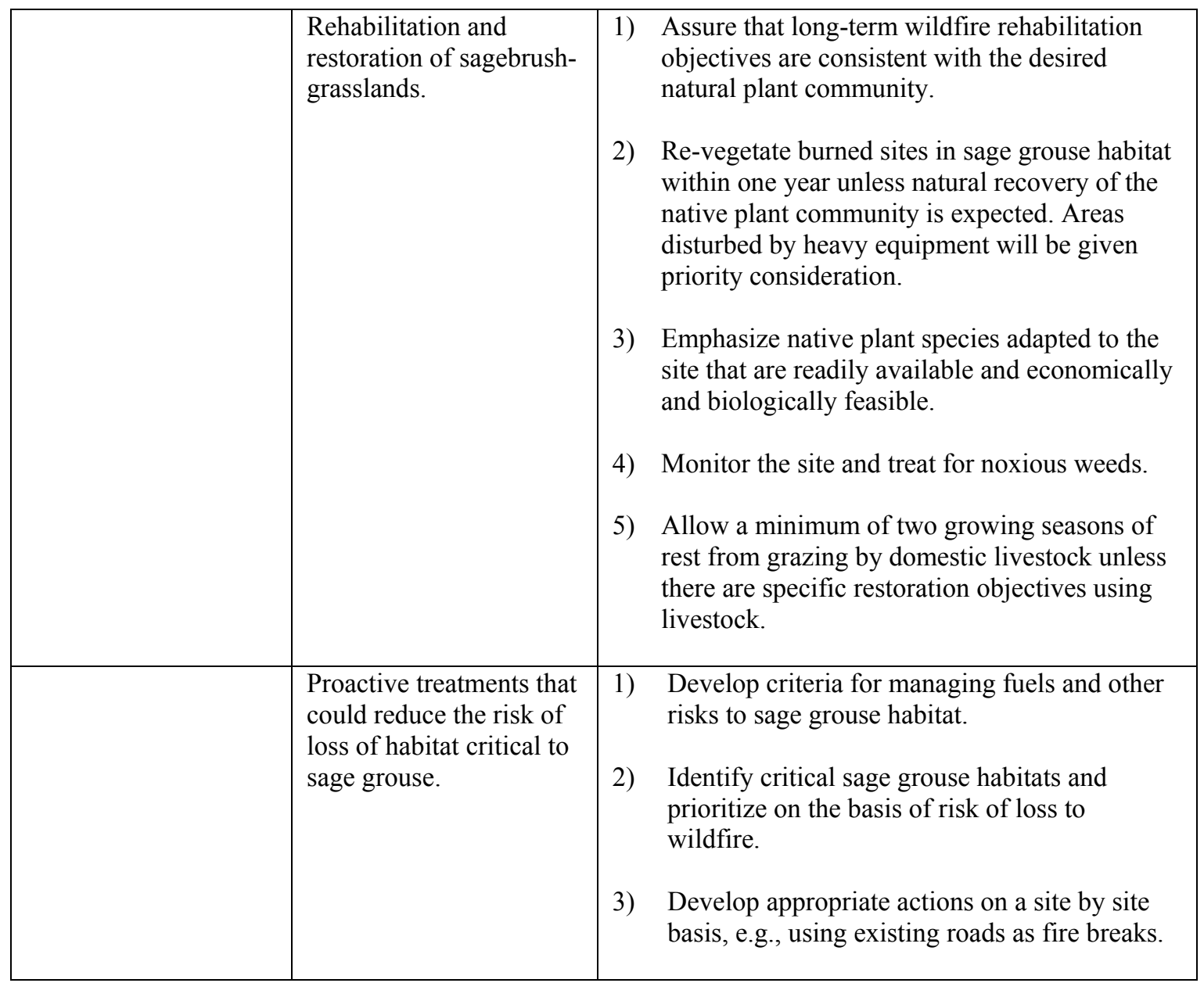

\section{Harvest Management}

Hunting is a direct form of mortality to sage grouse. There is disagreement concerning its overall impact on sage grouse populations. Some believe that hunting sage grouse is compatible with healthy sage grouse populations, while others do not think "surplus birds" should be removed from what they see as a species "at risk."

Sage grouse abundance is affected by long- and short-term population changes. In Montana, long-term population declines have been related to loss of sagebrush habitats essential to sage grouse (Martin 1970, Swenson et al. 1987). Although not irreversible in nature, conditions resulting in long-term declines are likely to persist. Within the long-term decline are short-term fluctuations (Eustace 2002) in sage grouse abundance, which appear cyclic in nature, reaching a low point mid-way through each decade. Variable climatic events, e.g., drought or severe winters, contribute to short-term changes in abundance (Edwards 1988).

Sage grouse hunting is an economically, recreationally, and culturally important tradition in many areas. In sagebrush habitats, sage grouse often are the only upland bird available for harvest, providing a recreational opportunity that would otherwise be unavailable over millions of acres. Analysis of wings collected from hunters is the best source of information on annual 
productivity of sage grouse and the influence of changing climatic conditions on productivity and population composition. Juvenile/adult ratios generated by wing analysis also can indicate approaching changes in male attendance on leks in subsequent years. Lek counts, which determine the number of active leks, are the best source of population trend information.

Sage grouse exhibit relatively low productivity and high survival when compared with other upland birds in Montana, which lends a degree of stability to the population. Nevertheless, sage grouse have significantly declined or have been extirpated in some areas of the state. Although loss or degradation of habitat, coupled with shifts in weather patterns and changes in predator composition and abundance, is largely responsible for local extirpation and population declines, harvest may be additive to natural mortality in some situations. In such cases, harvest could contribute to local declines or slow recovery of sage grouse populations. Developing an adaptive harvest management strategy (see Adaptive Harvest Strategy in the Appendix), based on monitoring of population trends, i.e., lek surveys, allows for more liberal seasons where populations are documented to be stable or increasing. If habitat becomes restricted and population trends decline, or the status is unknown because of a lack of monitoring, seasons should be conservative or suspended. Although sage grouse population status and trends vary across Montana, recent harvest regulations are uniform across the state. More regional flexibility may benefit isolated populations.

\section{How can we maintain sage grouse hunting without impacting the viability of sage grouse populations and the public's sage grouse hunting opportunity?}

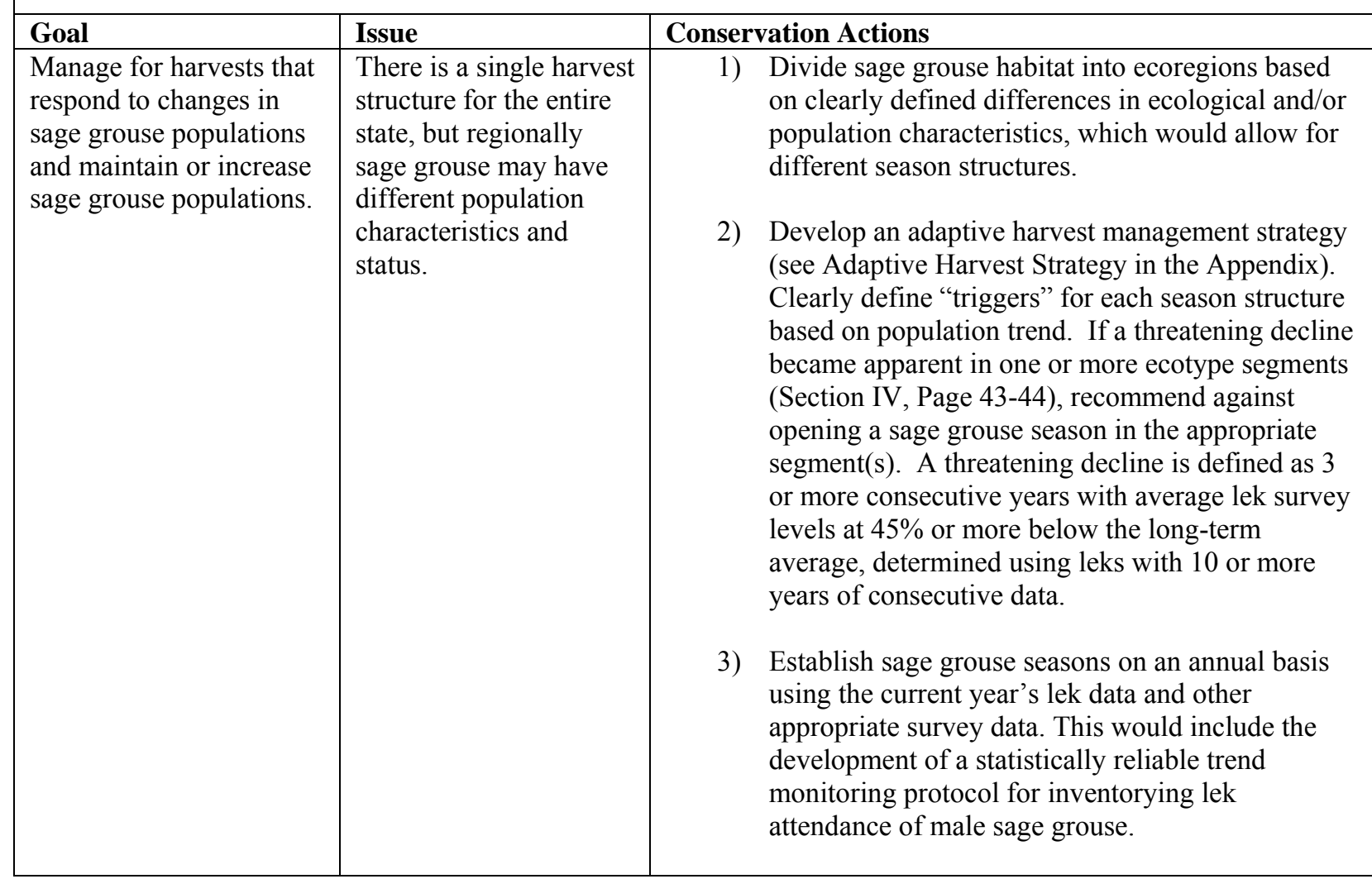




\begin{tabular}{|l|l|l|}
\hline & $\begin{array}{l}\text { There are strongly } \\
\text { opposed viewpoints on } \\
\text { the influence of hunting } \\
\text { on sage grouse } \\
\text { populations. }\end{array}$ & $\begin{array}{l}\text { 1) } \\
\text { influence of hunting on sage grouse in Montana } \\
\text { and what would constitute a maximum harvest } \\
\text { rate. }\end{array}$ \\
& 2) $\begin{array}{l}\text { Establish standardized wing collection protocol to } \\
\text { evaluate the influence of environmental conditions } \\
\text { on sage grouse productivity and population trends. }\end{array}$ \\
3) $\begin{array}{l}\text { Identify small populations of sage grouse that are } \\
\text { genetically isolated from other populations that } \\
\text { could be at risk of overharvest. }\end{array}$ \\
4) $\begin{array}{l}\text { Expand public information efforts designed to } \\
\text { increase public awareness of the role of sage } \\
\text { grouse hunting. }\end{array}$ \\
\hline
\end{tabular}

\section{Livestock Grazing Management}

Sagebrush communities provide critical habitat for sage grouse, produce a diversity of tangible commodities, and satisfy many societal values that are important to the U.S. economy and the well-being of Montana and U.S. citizens. Sagebrush-dominated rangeland in Montana that is occupied by sage grouse includes private, tribal, state, and federal lands.

Rangelands in Montana and the Northern Great Plains evolved with grazing and extreme climatic disturbances. However, many western rangelands were over-stocked with livestock in the late-1800s and early 1900s, thus altering the composition and productivity of some sagebrush and other vegetative communities. With the development and implementation of proper range management practices, vegetation condition of many rangelands has improved.

Sagebrush communities typically have forage value for livestock as well as providing quality habitat for sage grouse. Livestock effects on sage grouse habitat, and on the birds, may be positive, negative, or neutral depending on the specific grazing prescription and on the ecological site. Livestock grazing has been responsible for retaining expansive tracts of sagebrushdominated rangeland from conversion to cropland. In terms of habitat quality, properly managed grazing can stimulate growth of grasses and forbs, and thus livestock can be used to manipulate the plant community toward a desired condition. For example, rest-rotation grazing systems designed after Hormay (1970) provide for long-term range health and, in comparison to other systems, was found to produce up to four times as many prairie grouse (i.e., sharp-tailed grouse and prairie chickens) compared with other grazing systems on the Fort Pierre National Grasslands (Rice and Carter 1982). Although this study doesn't address sage grouse directly, the effect of improved residual cover, in response to grazing management, would likely have positive implications for sage grouse habitat. Management may not, however, restore all degraded range through grazing alone. Likewise, appropriate grazing practices may not totally compensate for other influences affecting sage grouse abundance. 
In response to environmental concerns, livestock operators and other land managers have developed stock water sources on uplands and have constructed fences to shift grazing from riparian to upland areas. Meeting objectives for riparian areas may increase removal of vegetation on upland sites. To minimize the potential impact of removing important understory vegetation, flexible grazing management programs need to be planned and implemented while considering the needs of sage grouse. Land managers also should consider potential effects, such as disturbance or mechanical damage to sagebrush, caused by livestock concentrations near leks during the breeding season or on key winter habitats.

Cooperative research is needed to identify and evaluate the effects of various grazing management plans on the interaction of sage grouse, commodity production, and societal values. Results should be used to develop grazing plans that eliminate or minimize potential conflicts.

Prescribed grazing standards and best management practices as described in Best Management Practices for Grazing (Montana Department of Natural Resources and Conservation 1999) are recommended as methods that can be used to implement many of the grazing actions in this section. In addition, the conservation actions in this section describe some considerations that may be specific to sage grouse and sagebrush habitats.

\section{How can we maintain and enhance sagebrush rangelands to provide productive sage grouse habitat while providing for commodities and values desired by society?}

\begin{tabular}{|c|c|c|}
\hline Goal & Issue & Conservation Actions \\
\hline $\begin{array}{l}\text { Manage grazing to } \\
\text { maintain the soil } \\
\text { conditions and ecological } \\
\text { processes necessary for a } \\
\text { properly functioning } \\
\text { sagebrush community } \\
\text { that addresses the long- } \\
\text { term needs of sage } \\
\text { grouse and other } \\
\text { sagebrush associated }_{\text {species. }}^{\text {a }}\end{array}$ & $\begin{array}{l}\text { Conflicting priorities } \\
\text { for land uses, species, } \\
\text { and habitats }\end{array}$ & $\begin{array}{l}\text { 1) Use scientific data and historic information to establish } \\
\text { baseline information when evaluating soil conditions } \\
\text { and ecological processes and when monitoring } \\
\text { seasonal sage grouse habitats. } \\
\text { 2) Set specific habitat objectives and implement } \\
\text { appropriate grazing management to achieve those } \\
\text { objectives and maintain or improve vegetation } \\
\text { condition and trends. } \\
\text { 3) Offer private landowners incentives when and where } \\
\text { appropriate to achieve sage grouse objectives. }\end{array}$ \\
\hline $\begin{array}{l}{ }^{a} \text { Desired conditions for } \\
\text { sage grouse are covered } \\
\text { in Section IV and in the } \\
\text { WAFWA Guidelines in } \\
\text { the Appendix. }\end{array}$ & & \\
\hline & $\begin{array}{l}\text { Some sagebrush } \\
\text { communities may have } \\
\text { been significantly } \\
\text { altered by past grazing } \\
\text { management practices }\end{array}$ & $\begin{array}{l}\text { 1) Implement appropriate grazing management strategies } \\
\text { and range management practices where soil conditions } \\
\text { and ecological processes will support sage grouse and } \\
\text { desired commodities and societal values. } \\
\text { 2) Establish suitable goals for sagebrush communities that } \\
\text { have deteriorated to such an extent that livestock } \\
\text { management alone may not contribute to habitat } \\
\text { objectives. }\end{array}$ \\
\hline
\end{tabular}




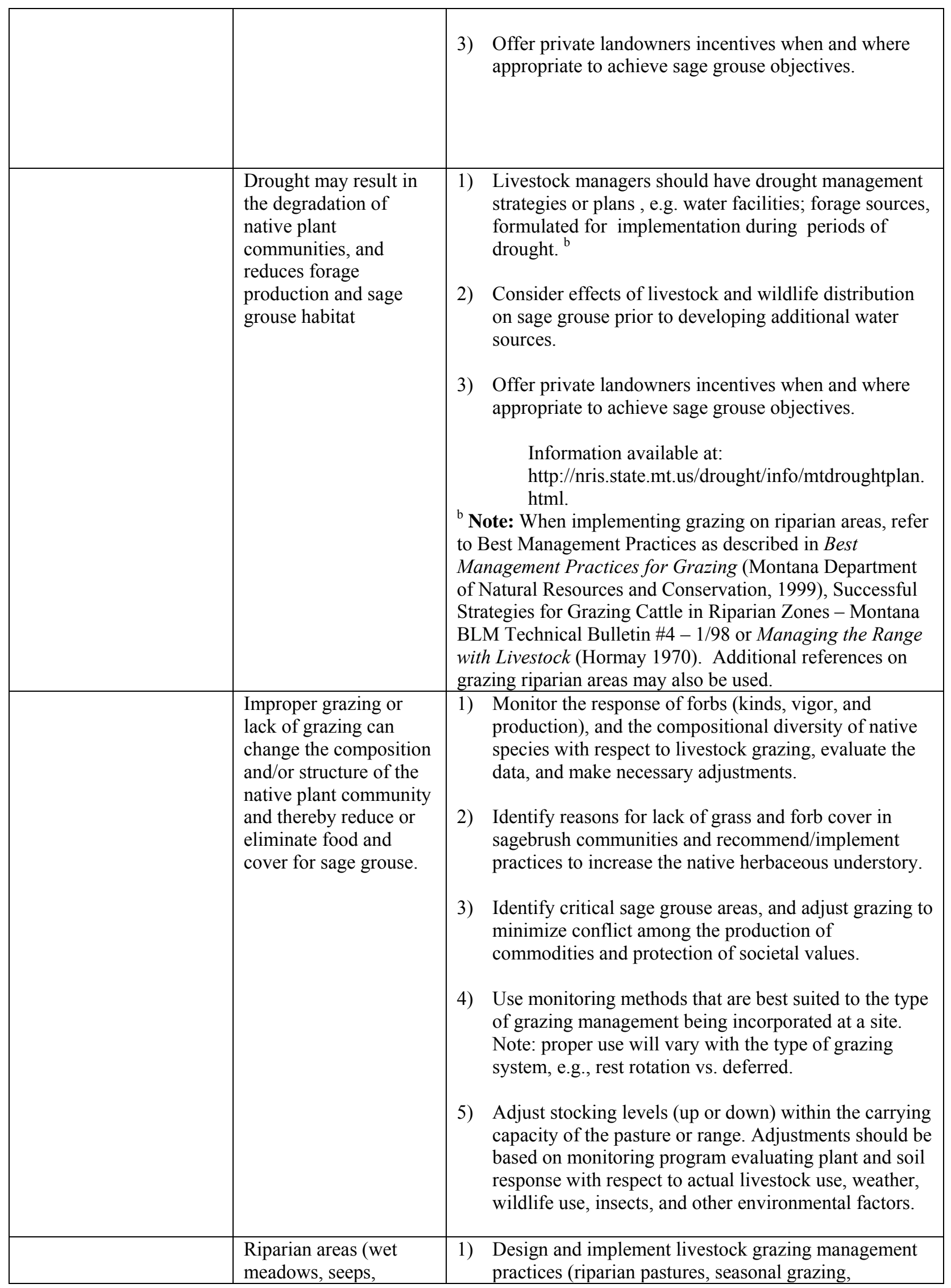




\begin{tabular}{|c|c|c|c|}
\hline & $\begin{array}{l}\text { streams) are important } \\
\text { resources for sage } \\
\text { grouse and livestock. }\end{array}$ & $\begin{array}{l}\text { 2) } \\
\text { 3) }\end{array}$ & $\begin{array}{l}\text { development of off-stream water facilities, etc.) to } \\
\text { achieve riparian management objectives. } \\
\text { Modify or adapt pipelines and natural springs, where } \\
\text { practical, to create small wet meadows as brood } \\
\text { habitat. } \\
\text { Ensure the sustainability of desired soil conditions and } \\
\text { ecological processes within upland plant communities } \\
\text { following implementation of strategies to protect } \\
\text { riparian areas. This can be achieved by: } \\
\text { a) protecting natural wet meadows and springs from } \\
\text { over-use while developing water for livestock, and } \\
\text { 1) plan the location, design, and construction of new } \\
\text { fences to minimize impacts on sage grouse. See } \\
\text { criteria for fencing on page VI-9. }\end{array}$ \\
\hline & $\begin{array}{l}\text { Potential for sage } \\
\text { grouse to be disturbed } \\
\text { or displaced by } \\
\text { concentrations of } \\
\text { livestock near leks or } \\
\text { winter habitat. }\end{array}$ & 1) & $\begin{array}{l}\text { Discourage concentration of livestock on leks or other } \\
\text { key sage grouse habitats. } \\
\text { a) Avoid placement of salt or mineral supplements } \\
\text { near leks during the breeding season (Mar-Jun), } \\
\text { and } \\
\text { b) Avoid supplemental winter feeding of livestock, } \\
\text { where practical, on sage grouse winter habitat and } \\
\text { around leks. }\end{array}$ \\
\hline & $\begin{array}{l}\text { Sage grouse seasonal } \\
\text { ranges often encompass } \\
\text { private, tribal, state, and } \\
\text { federal land. Habitat } \\
\text { values across the } \\
\text { respective ownership } \\
\text { are important to sage } \\
\text { grouse. }\end{array}$ & 1) & $\begin{array}{l}\text { Encourage land management practices that provide for } \\
\text { maintaining or enhancing sage grouse habitat on } \\
\text { private, tribal, state, and federal land. } \\
\text { Encourage the coordination of management activities } \\
\text { on both properties to provide yearlong benefits to sage } \\
\text { grouse. This may require reasonable compromise in } \\
\text { establishing management practices to achieve specific } \\
\text { goals. } \\
\text { Offer private landowners incentives when and where } \\
\text { appropriate to achieve sage grouse objectives. }\end{array}$ \\
\hline $\begin{array}{l}\text { Assess the impacts of } \\
\text { fencing for livestock on } \\
\text { sage grouse and sage } \\
\text { grouse habitats. }\end{array}$ & $\begin{array}{l}\text { Existing fences near } \\
\text { breeding, brood- } \\
\text { rearing, or winter } \\
\text { habitats can increase } \\
\text { the risk of collision } \\
\text { mortalities and/or } \\
\text { predation on sage } \\
\text { grouse by hawks, } \\
\text { eagles, and ravens by } \\
\text { providing perches. }\end{array}$ & 1) & $\begin{array}{l}\text { If portions of existing fences are found to pose a } \\
\text { significant threat to sage grouse as strike sites or raptor } \\
\text { perches, mitigate through moving or modifying posts, } \\
\text { implementation of predator control program, etc. } \\
\text { Actions may include increasing the visibility of the } \\
\text { fences by flagging or by designing "take-down" fences. } \\
\text { Offer private landowners incentives when and where } \\
\text { appropriate to achieve sage grouse objectives. }\end{array}$ \\
\hline
\end{tabular}




\begin{tabular}{|c|c|c|c|}
\hline & $\begin{array}{l}\text { Proposal of new fences } \\
\text { near sage grouse leks } \\
\text { and winter ranges. }\end{array}$ & 2) & $\begin{array}{l}\text { Current practices of avoiding placing fences through or } \\
\text { near leks and winter ranges on state and federal lands } \\
\text { should be continued. Similar practices should be } \\
\text { considered on private and tribal lands. } \\
\text { Offer private landowners incentives when and where } \\
\text { appropriate to achieve sage grouse objectives. }\end{array}$ \\
\hline $\begin{array}{l}\text { Minimize impacts of } \\
\text { using pesticides and } \\
\text { herbicides to control } \\
\text { insects and herbaceous } \\
\text { plants that provide a food } \\
\text { source for grouse. }\end{array}$ & $\begin{array}{l}\text { Pesticides and } \\
\text { herbicides may } \\
\text { adversely impact the } \\
\text { kinds and number of } \\
\text { foods available in the } \\
\text { form of insects and } \\
\text { forbs and can directly } \\
\text { affect chick survival. }\end{array}$ & 1) & $\begin{array}{l}\text { Evaluate ecological consequences of using pesticides } \\
\text { to control grasshoppers or other insects. } \\
\text { Evaluate ecological consequences of broadcast } \\
\text { herbicide use on forbs and other important sage grouse } \\
\text { foods. } \\
\text { Minimize use of pesticides and herbicides within } 1 \\
\text { mile of known grouse nests, leks, or brood-rearing } \\
\text { areas. } \\
\text { Develop educational materials detailing the effects of } \\
\text { pesticides and herbicides that can be used to evaluate } \\
\text { their effects on sage grouse. }\end{array}$ \\
\hline
\end{tabular}

\section{Mining and Energy Development}

Many of the nation's oil and gas resources are located under sage grouse habitats across the western U.S. Different levels of energy activity can affect sage grouse populations if habitats are lost, fragmented, or changed in ways unfavorable to grouse.

Effects of oil and gas development on sage grouse are not extensively documented. Exploration and development may negatively affect sage grouse habitat and populations, but long-term impacts after reclamation are not clearly understood. Research suggests that energy development can displace sage grouse and that displaced grouse may return in some cases to the site after energy-related activities have ceased, but populations may not attain pre-development levels. Declines are attributed to effects of human disturbance, roads and power lines that fragment habitat, placement of infrastructure in areas once free from structures, alteration of vegetation composition through introduction of noxious weeds and other non-native plants, and disruptive noise near leks. Initial site disturbance and remaining structures can potentially enhance habitat for avian and mammalian predators.

Current research in several western states is directed at identifying and quantifying impacts of energy development on sage grouse. 


\section{How can we meet our energy demands and minimize impacts to sage grouse and sagebrush habitats?}

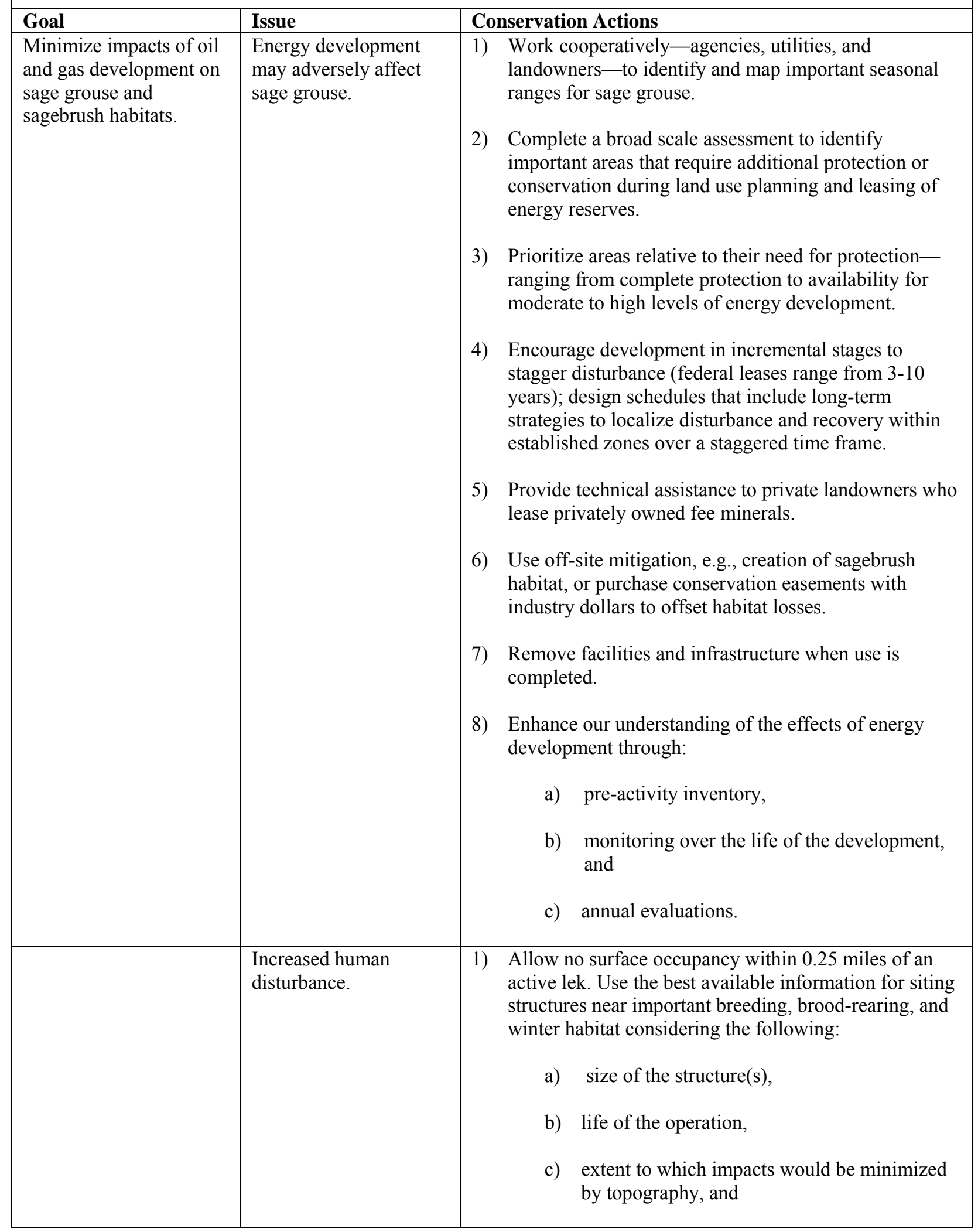




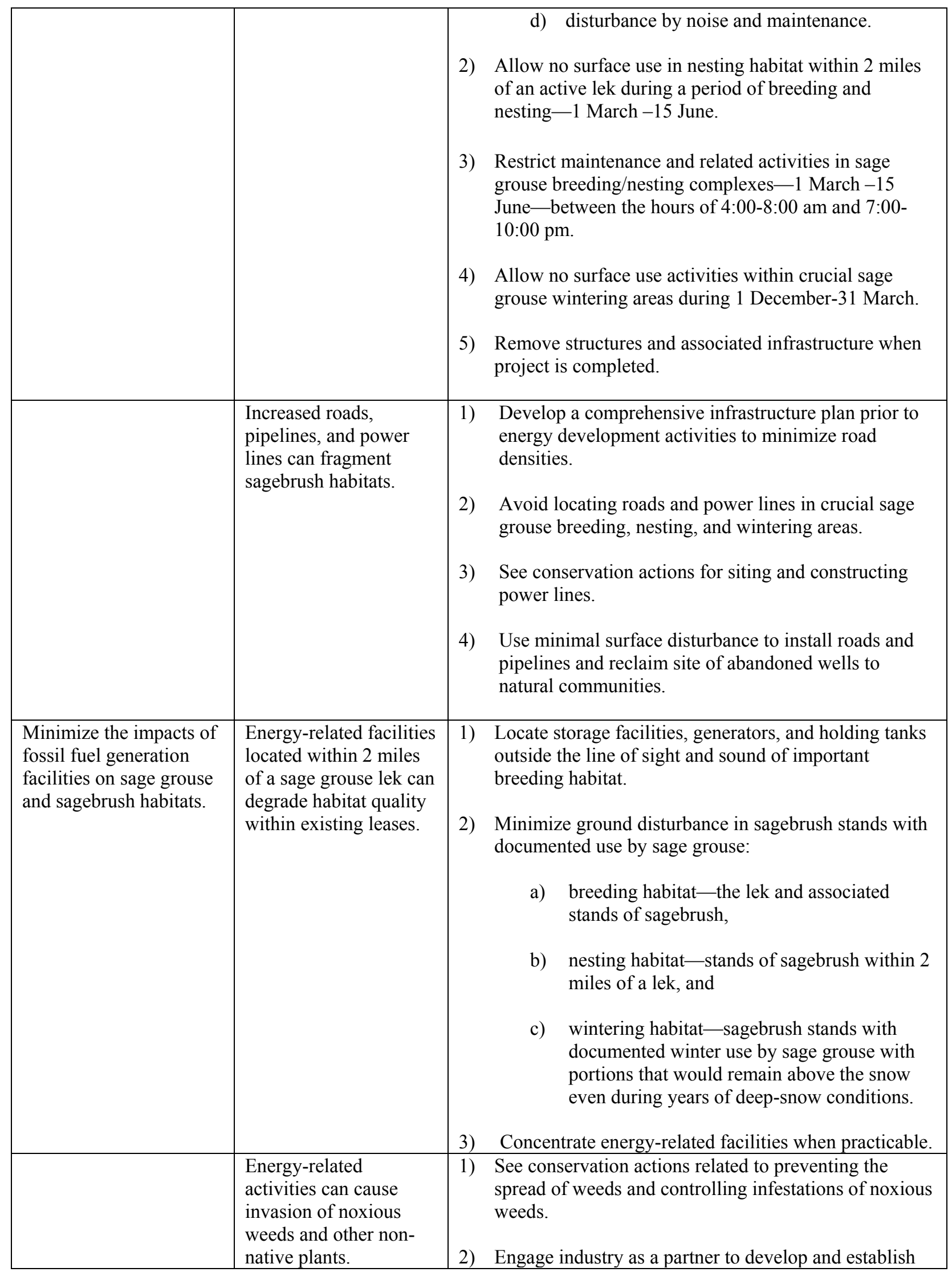




\begin{tabular}{|c|c|c|c|}
\hline & & & $\begin{array}{l}\text { new sources of seed of native plant species for } \\
\text { restoration of sites disturbed by development. }\end{array}$ \\
\hline & $\begin{array}{l}\text { Noise can disrupt } \\
\text { breeding rituals and } \\
\text { cause abandonment of } \\
\text { leks. }\end{array}$ & 1) & $\begin{array}{l}\text { Restrict noise levels from production facilities to } 49 \\
\text { decibels (10 dba above background noise at the lek). } \\
\text { Restrict use of heavy equipment that exceeds } 49 \\
\text { decibels within } 2 \text { miles of a lek from } 4 \text { a.m.- } 8 \text { a.m. and } \\
7 \text { p.m. - } 10 \text { p.m. during March 1-June } 15 .\end{array}$ \\
\hline & $\begin{array}{l}\text { Water discharge and } \\
\text { impoundments can } \\
\text { degrade or inundate } \\
\text { breeding, nesting, and } \\
\text { winter habitat. }\end{array}$ & 1) & $\begin{array}{l}\text { Design impoundments and manage discharge so as not } \\
\text { to degrade or inundate leks, nesting sites, and wintering } \\
\text { sites. } \\
\text { Protect natural springs from any source of disturbance } \\
\text { or degradation from energy-related activities. }\end{array}$ \\
\hline $\begin{array}{l}\text { Provide for the least } \\
\text { obtrusive regulation of } \\
\text { oil and gas activities } \\
\text { while providing for } \\
\text { needs of sage grouse. }\end{array}$ & $\begin{array}{l}\text { Siting requirements } \\
\text { need to be re-examined } \\
\text { as technological } \\
\text { advances make } \\
\text { development more } \\
\text { compatible with sage } \\
\text { grouse needs. }\end{array}$ & 1) & $\begin{array}{l}\text { Provide for long-term monitoring of siting } \\
\text { requirements to examine effects of current and future } \\
\text { development on sage grouse. } \\
\text { Set up a schedule for reviewing and revising siting and } \\
\text { use criteria with industry. }\end{array}$ \\
\hline
\end{tabular}

\section{Noxious Weed Management}

Over the last 50 years, noxious weeds have spread at an unprecedented rate across Montana. Certain species of plants are currently designated as "noxious" in Montana (http://www.mtweed.org/Identification/identification.html). "Noxious" applies only to species so designated by the Montana Department of Agriculture (DA). County weed boards may add species to local lists that have not been designated by the state, but at a minimum must include those species designated by DA. Resource managers, both public and private, have a statutory responsibility to develop management plans for treatment of noxious weeds on the land they own and/or manage (7-22-2115, MCA). The magnitude of weed infestations, however, often prevents appropriate and timely treatments.

Noxious weeds and other invasive plant species, such as annual grasses, displace more desirable native plant species and cause significant adverse biological and economic effects by reducing productivity of healthy rangeland. Noxious weeds impact all classes of wildlife and domestic livestock. Plant species designated as noxious weeds are classified as either established and spreading or newly introduced--or are recognized as potential invaders. Noxious weed species present in adjoining states and provinces are a threat in Montana.

Although introduction and subsequent spread of weeds can occur through several means, the most pervasive occurs along transportation and floodplain corridors. One of the primary concerns of resource managers is the spread of noxious weeds by vehicles. Disturbed ground typically serves as the initial point of establishment, with the amount of disturbed ground being directly proportional to the overall susceptibility of an area to weed invasion. 
Disturbance can take many forms and causes - the most common being human-caused activities, such as road building and use and the rise of rural subdivisions. Often overlooked, but equally important, are climatological and biological influences. Recurrent flooding and wildfires, as well as prolonged drought, can disturb plants and topsoil over large areas. Biological forms of ground disturbance include burrowing activities by small mammals and localized over-use by livestock and/or wild ungulates. These large- and small-scale disturbances provide opportunity for invasive species to become established.

Herbicide treatment is the most widely employed method to control noxious weeds. For most noxious weeds in Montana, this method of treatment provides immediate, effective results. Problems occur when weed seeds have been allowed to build up in the soil and/or surrounding land areas and left untreated. Re-establishment in such cases occurs from seed banks and off-site reinvasion. This cycle of treatment/re-establishment is expensive to treat and requires dedication and immediate action by resource managers when weeds reappear within treated areas. Prevention, which requires focused purposeful action in surrounding infested and uninfested areas, provides the most cost-effective control. Prevention works best when management strategies acknowledge a threat and prioritize efforts to eliminate potential sources of infestation and expansion.

Chemical control of noxious weeds is efficient but might pose some toxicological risk to sage grouse and other wildlife during treatment. Pathways of exposure include absorption from treated plants, inhalation of chemical particles suspended in the atmosphere, and direct ingestion of treated plants (Montana Fish, Wildlife and Parks 1994). If properly applied, however, toxicological risks would be minimal. A reduction of forbs important to sage grouse during brood-rearing could have more serious consequences to local populations, with the magnitude of effects dependent on the scale of treatment. However, resource managers must realize that untreated noxious weeds are ultimately more effective at competitively displacing desirable plant components than short-term, transient impacts from proper herbicide application.

\section{How can we minimize impacts of noxious weeds and other invasive species and their control on sage grouse?}

\begin{tabular}{|l|l|l|}
\hline Goal & Issue & Conservation Actions \\
\hline $\begin{array}{l}\text { Identify current noxious } \\
\text { weed infestations within } \\
\text { and adjacent to occupied } \\
\text { sage grouse habitat or } \\
\text { suspected ranges. }\end{array}$ & $\begin{array}{l}\text { Current information on } \\
\text { existing weed } \\
\text { infestations is } \\
\text { insufficient for } \\
\text { successful weed } \\
\text { management. }\end{array}$ & $\begin{array}{l}\text { 1) } \\
\text { Inventory and map existing noxious weed populations } \\
\text { within and adjacent to occupied sage grouse habitat or } \\
\text { suspected range. }\end{array}$ \\
$\begin{array}{l}\text { Implement habitat- } \\
\text { specific weed } \\
\text { management plans for } \\
\text { known sage grouse } \\
\text { ranges. }\end{array}$ & $\begin{array}{l}\text { Appropriate weed } \\
\text { management can't be } \\
\text { performed without } \\
\text { habitat-specific } \\
\text { information. }\end{array}$ & $\begin{array}{l}\text { 1) } \\
\text { Develop habitat-specific weed management plans for } \\
\text { map information developed in the action described } \\
\text { above. }\end{array}$ \\
\hline
\end{tabular}




\begin{tabular}{|c|c|c|c|}
\hline $\begin{array}{l}\text { Maintain habitat quality } \\
\text { for both wildlife and } \\
\text { livestock interests } \\
\text { through proactive weed } \\
\text { management. }\end{array}$ & $\begin{array}{l}\text { Weed infestations result } \\
\text { in loss of native grass, } \\
\text { forb, and sagebrush } \\
\text { abundance and } \\
\text { diversity. }\end{array}$ & 1) & $\begin{array}{l}\text { Promote measures that prevent the introduction and } \\
\text { spread of weed seeds and other reproducing plant parts. }\end{array}$ \\
\hline $\begin{array}{l}\text { Prevent the initial } \\
\text { establishment of weeds } \\
\text { within or on lands } \\
\text { surrounding sage grouse } \\
\text { habitat. }\end{array}$ & $\begin{array}{l}\text { Noxious weeds spread } \\
\text { quickly and without } \\
\text { regard to ownership or } \\
\text { management } \\
\text { boundaries. Without } \\
\text { immediate treatment, } \\
\text { noxious weeds become } \\
\text { a problem to all } \\
\text { surrounding } \\
\text { landowners. Effective } \\
\text { weed management } \\
\text { cannot occur in } \\
\text { isolation or to the } \\
\text { exclusion of any land } \\
\text { managers within an } \\
\text { area. }\end{array}$ & 1) & $\begin{array}{l}\text { Develop and implement management techniques that } \\
\text { minimize the risk of infestation. } \\
\text { Use weed seed-free livestock forage and mulch. } \\
\text { Thoroughly clean personal clothing, pets, all vehicles } \\
\text { and machinery before moving into non-infested areas. } \\
\text { Where feasible, isolate livestock from known } \\
\text { infestations and avoid vehicle movement through } \\
\text { infested areas. } \\
\text { Delay movement of livestock for a time period } \\
\text { necessary to prevent viable weed seeds from passing } \\
\text { through animals' digestive tracts or remaining } \\
\text { physically attached when moving from infested to non- } \\
\text { infested areas. } \\
\text { Use weed-free seed for re-establishment of vegetation. } \\
\text { Eliminate unnecessary soil disturbance and vehicle } \\
\text { access/movement into occupied sage grouse habitat. } \\
\text { Limit vehicle use to established roads only. } \\
\text { Regularly monitor access points and roads for weed } \\
\text { establishment. }\end{array}$ \\
\hline $\begin{array}{l}\text { Ensure that land } \\
\text { managers and users } \\
\text { (general public) are } \\
\text { educated about the threat } \\
\text { noxious weeds pose to } \\
\text { native plant communities } \\
\text { and work together to find } \\
\text { appropriate management } \\
\text { solutions. }\end{array}$ & $\begin{array}{l}\text { Cooperative integrated } \\
\text { weed management } \\
\text { efforts are essential in } \\
\text { order to have successful } \\
\text { sage grouse habitat. }\end{array}$ & 1) & $\begin{array}{l}\text { Develop partnerships with regional public and private } \\
\text { land management units. Solicit involvement of local } \\
\text { weed management specialists, private landowners, } \\
\text { wildlife biologists, and range ecologists to share } \\
\text { knowledge and responsibilities on noxious weed } \\
\text { issues. } \\
\text { Establish goals and set priorities that encompass the } \\
\text { needs of both livestock and wildlife managers so all } \\
\text { parties are working under a similar plan. } \\
\text { Provide training to appropriate staff on the proper } \\
\text { selection and use of herbicides, including effects that } \\
\text { climatic conditions and soils types have on } \\
\text { applications of herbicides. } \\
\text { Maintain proper operating herbicide application } \\
\text { equipment as well as proper herbicide application } \\
\text { records, according to Montana pesticide laws. } \\
\text { Conduct monitoring and develop follow-up } \\
\text { procedures for treated areas. }\end{array}$ \\
\hline
\end{tabular}




\begin{tabular}{|c|c|c|c|}
\hline & & $\begin{array}{l}\text { 6) } \\
\text { 7) }\end{array}$ & $\begin{array}{l}\text { Participate in integrated weed management training } \\
\text { conducted by state and federal agencies, local } \\
\text { experiment stations, and local (county) weed districts. } \\
\text { Educate all field personnel on weed identification, } \\
\text { manner in which weeds spread, and methods of } \\
\text { treating weed infestations. }\end{array}$ \\
\hline $\begin{array}{l}\text { Minimize effects of weed } \\
\text { control treatments on } \\
\text { non-target organisms. }\end{array}$ & $\begin{array}{l}\text { It is important to } \\
\text { maintain viable } \\
\text { sagebrush habitat and } \\
\text { populations of sage } \\
\text { grouse while } \\
\text { eradicating infestations } \\
\text { of noxious weeds. }\end{array}$ & 3) & $\begin{array}{l}\text { Employ integrated weed management treatment } \\
\text { methods such as a combination of biological and } \\
\text { cultural, e.g., grazing, mowing, or seeding, } \\
\text { treatments in conjunction with herbicides to manage } \\
\text { weeds in sage grouse habitat. } \\
\text { Use the most selective herbicides where chemical } \\
\text { treatment is appropriate, to minimize loss of non- } \\
\text { target plant species. } \\
\text { Restore plant communities with desired species } \\
\text { adapted to the site, using proven management } \\
\text { techniques where biologically feasible. A restoration } \\
\text { program may be necessary if conditions prevent } \\
\text { natural native plant reestablishment. }\end{array}$ \\
\hline \multirow[t]{3}{*}{$\begin{array}{l}\text { Provide the necessary } \\
\text { funding mechanisms and } \\
\text { dedicated labor to act } \\
\text { immediately when new } \\
\text { infestations are identified } \\
\text { within sage grouse } \\
\text { habitat. }\end{array}$} & $\begin{array}{l}\text { New weed infestations } \\
\text { are often undetected. }\end{array}$ & 1) & $\begin{array}{l}\text { Establish a monitoring protocol to detect new } \\
\text { infestations. }\end{array}$ \\
\hline & $\begin{array}{l}\text { Weed management may } \\
\text { not be an identified } \\
\text { budget item in sage } \\
\text { grouse management } \\
\text { plans. }\end{array}$ & 1) & $\begin{array}{l}\text { Weed management costs should be an identified } \\
\text { budget item in sage grouse management plans. Money } \\
\text { should be dedicated for monitoring and education as } \\
\text { well as direct treatment expenses. }\end{array}$ \\
\hline & $\begin{array}{l}\text { Funding and/or human } \\
\text { resources may not be } \\
\text { available when new } \\
\text { infestations are } \\
\text { discovered. }\end{array}$ & 1) & $\begin{array}{l}\text { Establish partnerships or formal agreements with local } \\
\text { (county) weed districts if appropriate to utilize their } \\
\text { equipment and/or personnel. }\end{array}$ \\
\hline
\end{tabular}

\section{Outreach, Education, and Implementation}

Public education, outreach, and "inreach" (communication within agencies and groups to increase understanding) about sage grouse conservation should be undertaken through a partnership between state and federal agencies, non-governmental organizations, and citizens. Effective conservation of sage grouse requires collaboration between public land managers, private landowners, wildlife professionals, extension service agents, tribes, and other interests to develop and implement appropriate regional protection strategies. 
After this sage grouse conservation plan has been reviewed by the public and approved by participating agencies, local work groups will convene to implement it. Implementation requires a sound biological foundation. Most of the information about shrub-steppe habitats and sage grouse is contained in technical manuscripts. User-friendly information is needed to manage habitats to conserve sage grouse and other sagebrush-associated species. Participating agencies, groups, and individuals will need to develop and provide educational material about sage grouse and their needs and new research findings as they become available. A procedure has been developed for data distribution (See Section VIII).

\section{How can we inform the public and agencies about sage grouse populations and habitat needs, and coordinate the implementation of Montana's conservation plan on both public and private lands?}

\begin{tabular}{|c|c|c|}
\hline Goal & Issue & Conservation Action \\
\hline $\begin{array}{l}\text { Improve public and } \\
\text { agency understanding } \\
\text { about conservation of } \\
\text { sage grouse and } \\
\text { sagebrush communities. }\end{array}$ & $\begin{array}{l}\text { The general public } \\
\text { and agency staffs have } \\
\text { not been exposed to } \\
\text { current information on } \\
\text { ecological needs and } \\
\text { methods for } \\
\text { conserving sage } \\
\text { grouse and sagebrush } \\
\text { habitats. Materials are } \\
\text { needed to present this } \\
\text { information. }\end{array}$ & $\begin{array}{l}\text { 1) Develop educational materials (brochure, Power Point } \\
\text { presentation, camera-ready ads, press releases, public } \\
\text { service announcements, event invitations and surveys, } \\
\text { websites, newsletters, and research information). } \\
\text { 2) Present materials in a series of community meetings } \\
\text { that bring statewide technical group participants and } \\
\text { regional agency staff together with local people. } \\
\text { 3) Consider Resource Advisory Committees and other } \\
\text { regional and local opportunities for education and } \\
\text { outreach. } \\
\text { 4) Encourage public participation in censusing leks and } \\
\text { other volunteer projects, including the general public } \\
\text { on public lands and private landowners on their own } \\
\text { properties. }\end{array}$ \\
\hline $\begin{array}{l}\text { Gain agency and public } \\
\text { understanding, input, and } \\
\text { endorsement of the } \\
\text { Montana Sage Grouse } \\
\text { Conservation Plan }\end{array}$ & $\begin{array}{l}\text { The general public } \\
\text { and agency staff may } \\
\text { not initially } \\
\text { understand, and } \\
\text { therefore support, the } \\
\text { plan. }\end{array}$ & $\begin{array}{l}\text { 1) Distribute the plan via hard copy and website. } \\
\text { 2) Develop and implement a communications plan that } \\
\text { identifies the audience and the message. } \\
\text { 3) Prepare an executive summary of the plan. } \\
\text { 4) Review and reconcile public concerns. }\end{array}$ \\
\hline $\begin{array}{l}\text { Implement a } \\
\text { conservation strategy for } \\
\text { sage grouse using the } \\
\text { Montana Statewide } \\
\text { Conservation Plan as a } \\
\text { model. }\end{array}$ & $\begin{array}{l}\text { Implementing a } \\
\text { statewide plan in light } \\
\text { of diverse } \\
\text { geographical, cultural, } \\
\text { and socio-economic } \\
\text { challenges poses a } \\
\text { challenge. }\end{array}$ & $\begin{array}{l}\text { 1) Implement the local work group concept. } \\
\text { 2) Coordinate efforts among work groups. }\end{array}$ \\
\hline
\end{tabular}




\begin{tabular}{|l|l|l|}
\hline & $\begin{array}{l}\text { Infomational materials } \\
\text { are needed for the } \\
\text { sage grouse } \\
\text { conservation effort in } \\
\text { Montana. }\end{array}$ & $\begin{array}{l}\text { 1) } \\
\text { 2) } \\
\text { that could be used to prevent the loss of sage grouse } \\
\text { habitat. }\end{array}$ \\
2) $\begin{array}{l}\text { Develop and distribute information on best } \\
\text { management practices and incentives. }\end{array}$ \\
3) $\begin{array}{l}\text { Request counties and agencies to designate a sage } \\
\text { grouse contact person to interface with county planning } \\
\text { authorities. }\end{array}$ \\
4) $\begin{array}{l}\text { Provide sage grouse habitat maps and } \\
\text { recommendations to county planners, public land } \\
\text { agencies, and other interest groups and land managers. }\end{array}$ \\
5) $\begin{array}{l}\text { Encourage county governments to offer incentives to } \\
\text { developers who protect and enhance sage grouse } \\
\text { habitat. }\end{array}$
\end{tabular}

Sagebrush obligates depend on sagebrush during breeding season or year round: these include sage sparrow, Brewer's sparrow, sage thrasher, sage grouse, pygmy rabbit, sagebrush vole, sagebrush lizard, pronghorn antelope. Many other species depend on the sagebrush community to a lesser degree. We refer to all these species as sagebrush-associated species

\section{Power Lines and Generation Facilities}

Both investor-owned electric utilities and Rural Electric Co-ops deliver electricity through power lines throughout the state. The current density of lines in sage grouse habitat is lower than in urban or other rural areas due to lower human population density. Increasingly popular rural subdivisions and increasing levels of energy development will account for most of the new power lines in sage grouse habitat.

Power lines can provide additional hunting perches for raptors in otherwise treeless areas. Sage grouse also may be injured or killed by flying into these structures. Power lines most likely impact grouse near leks, in brood-rearing habitat, and in wintering areas that also support large numbers of wintering raptors. Construction of new power lines contributes to habitat degradation when accompanied by new roads or other infrastructure, e.g., pipelines, fences, etc.

The U.S. Fish and Wildlife Service strongly encourages electric utilities to address raptor electrocution problems on power lines nationwide by preventing raptors from perching or making poles safe for raptors to perch on. Installation of perch prevention devices may protect raptors in areas with low densities of prey, but raptors will still try to land on such poles located near concentrations of prey. Utilities commonly make power poles safe for raptors to use as perches. This poses a dilemma for utilities in sage grouse habitat. It is important that parties 
involved with power lines utilize the Avian Power Line Action Committee 1994 guidelines when designing raptor perch sites and perch guards.

Burying lines would reduce or eliminate electrocution of raptors and perch sites. Burying highvoltage (Transmission) lines is very difficult both technically and economically. Burying lower voltage (Distribution) lines costs substantially more than equivalent overhead facilities and creates a potential for invasion of noxious weeds. Locating the cause of outages on underground lines is difficult and greatly increases the time required for subsequent repair. Underground repairs also involve a greater disturbance of ground and vegetation.

Proposed generation facilities may include fossil fuel plants (coal and natural gas) and wind power. Such facilities also may include associated infrastructure (buildings, roads, railroads, power lines, pipelines etc). When sited in sagebrush habitats, these plants and the associated infrastructure may contribute to destruction, fragmentation, or degradation of sagebrush habitats. Wind turbines may also cause direct mortality to sage grouse that fly into the rotating blades.

\section{How can we continue to provide electric service to customers and minimize impacts to sage grouse and sagebrush habitats?}

\begin{tabular}{|c|c|c|}
\hline Goal & Issue & Conservation Actions \\
\hline $\begin{array}{l}\text { Minimize the impacts of } \\
\text { power lines on sage } \\
\text { grouse and sagebrush } \\
\text { habitats. }\end{array}$ & $\begin{array}{l}\text { Existing power lines } \\
\text { near a lek, brood- } \\
\text { rearing habitat, or } \\
\text { winter habitat increases } \\
\text { the risk of predation on } \\
\text { sage grouse by raptors. }\end{array}$ & $\begin{array}{l}\text { 1) Document the segment(s) of line causing problems. } \\
\text { 2) Determine by cooperative action-agencies, utilities, } \\
\text { and landowners - whether or not modification of poles } \\
\text { to limit perching will prevent electrocution of raptors } \\
\text { and decrease predation on sage grouse. Inform } \\
\text { involved parties of and utilize Avian Power Line } \\
\text { Action Committee } 1994 \text { guidelines. } \\
\text { 3) Emphasize the following if perch prevention } \\
\text { modifications do not work to protect sage grouse and } \\
\text { sagebrush habitat: } \\
\text { a) reroute the line using distance, topography, or } \\
\quad \text { vegetative cover; or } \\
\text { b) bury the line. } \\
\text { 4) Explore opportunities for technical assistance and } \\
\text { funding. } \\
\text { 5) Remove power line when use is completed. }\end{array}$ \\
\hline & $\begin{array}{l}\text { New power lines } \\
\text { proposed in areas that } \\
\text { provide sage grouse } \\
\text { habitat can pose threats } \\
\text { to sage grouse. }\end{array}$ & $\begin{array}{l}\text { 1) Minimize the number of new lines in sage grouse } \\
\text { habitat. } \\
\text { 2) Site new lines in existing corridors wherever } \\
\text { practicable. }\end{array}$ \\
\hline
\end{tabular}




\begin{tabular}{|c|c|c|c|}
\hline & & $\begin{array}{l}\text { 7) } \\
\text { 8) } \\
\text { 9) }\end{array}$ & $\begin{array}{l}\text { Encourage the use of off-grid systems such as solar, } \\
\text { natural gas micro-turbines, and wind power where } \\
\text { feasible in sage grouse habitats. } \\
\text { Use the best available information for siting power } \\
\text { lines on important breeding, brood-rearing, and winter } \\
\text { habitat in an appropriate vicinity of the proposed line. } \\
\text { If siting is required within } 2 \text { miles of important } \\
\text { breeding, brood-rearing, and winter habitat (Connelly } \\
\text { et al. } 2000 \text { b), emphasize options for preventing raptor } \\
\text { perch sites utilizing Avian Power Line Action } \\
\text { Committee } 1994 \text { guidelines or bury a portion of the } \\
\text { line. } \\
\text { Develop a route-with agencies, utilities, and } \\
\text { landowners cooperating-that uses topography, } \\
\text { vegetative cover, site distance, etc. to effectively } \\
\text { protect identified sage grouse habitat in a cost efficient } \\
\text { manner. } \\
\text { Restrict timing for construction to prevent disturbance } \\
\text { during critical periods: } \\
\text { a) breeding-1 March-15 June } \\
\text { b) winter-1 December-31 March } \\
\text { Take appropriate measures to prevent introduction or } \\
\text { dispersal of noxious weeds during construction and } \\
\text { planned maintenance. } \\
\text { Remove power line when use is completed. }\end{array}$ \\
\hline & $\begin{array}{l}\text { Existing power line is } \\
\text { causing consistent or } \\
\text { significant collision } \\
\text { mortality on sage } \\
\text { grouse. }\end{array}$ & $\begin{array}{l}\text { 1) } \\
\text { 2) }\end{array}$ & $\begin{array}{l}\text { Document the segment(s) of line causing consistent or } \\
\text { biologically significant mortality—with agencies, } \\
\text { utilities, and landowners cooperating in the effort. } \\
\text { Initiate collision prevention measures using guidelines } \\
\text { (Avian Power Line Action Committee 1994) on } \\
\text { identified segments. Measures are subject to restriction } \\
\text { or modification for wind and ice loading or other } \\
\text { engineering concerns, or updated collision prevention } \\
\text { information. } \\
\text { Remove power lines that traverse important sage } \\
\text { grouse habitats when facilities being serviced are no } \\
\text { longer in use or when projects are completed. }\end{array}$ \\
\hline $\begin{array}{l}\text { Minimize the impacts of } \\
\text { fossil fuel generation } \\
\text { facilities on sage grouse } \\
\text { and sagebrush habitats. }\end{array}$ & $\begin{array}{l}\text { Fossil fuel generation } \\
\text { may impact sage grouse } \\
\text { and sage grouse habitat. }\end{array}$ & 1) & $\begin{array}{l}\text { Use the best available information to: } \\
\text { a) identify important sage grouse breeding, } \\
\text { brood-rearing, and winter habitat in an } \\
\text { appropriate vicinity of a proposed facility and } \\
\text { associated infrastructure; and }\end{array}$ \\
\hline
\end{tabular}




\begin{tabular}{|c|c|c|}
\hline & & 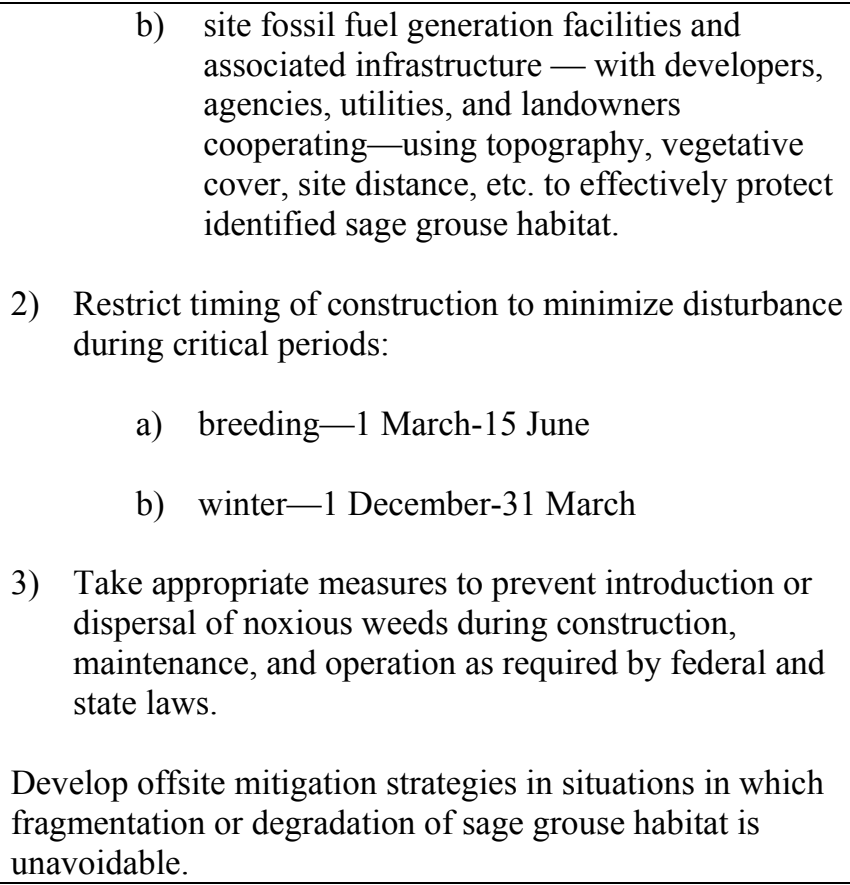 \\
\hline $\begin{array}{l}\text { Minimize the impacts of } \\
\text { wind generation facilities } \\
\text { on sage grouse and } \\
\text { sagebrush habitats. }\end{array}$ & $\begin{array}{l}\text { Wind generation may } \\
\text { impact sage grouse and } \\
\text { sage grouse habitat. }\end{array}$ & $\begin{array}{l}\text { 1) Consult with USFWS Ecological Services for site } \\
\text { selection evaluation information. } \\
\text { 2) Use the best available information to: } \\
\text { a) } \\
\text { identify important sage grouse breeding, } \\
\text { brood-rearing, and winter habitat in an } \\
\text { appropriate vicinity of a proposed facility and } \\
\text { associated infrastructure; and } \\
\text { b) site wind generation facilities-with agencies, } \\
\text { utilities, and landowners cooperating-using } \\
\text { topography, vegetative cover, site distance, } \\
\text { etc., to effectively protect identified sage } \\
\text { grouse habitat. } \\
\text { 3) Identify and avoid both local (daily) and seasonal } \\
\text { migration routes. } \\
\text { 4) Restrict timing of construction to minimize disturbance } \\
\text { during critical periods: } \\
\text { c) breeding-1 March-15 June } \\
\text { d) winter-1 December-31 March } \\
\text { Take appropriate measures to prevent introduction or } \\
\text { dispersal of noxious weeds during construction, } \\
\text { maintenance, and operation as required by federal and } \\
\text { state laws. } \\
\text { 6) Develop offsite mitigation strategies in situations in } \\
\text { which fragmentation or degradation of sage grouse } \\
\text { habitat is unavoidable. }\end{array}$ \\
\hline
\end{tabular}




\section{Predation}

Predator populations, their effects on sage grouse populations, and issues surrounding predator control concern landowners, wildlife managers, and the public. Some people believe that predator populations have increased due to lack of predator control and that predators are the primary factor limiting sage grouse populations. Others contend that habitat fragmentation and degradation are the primary reasons for population declines, and that these land use changes contribute to increased rates of predation.

Predation does impact sage grouse to varying degrees. The impact of predation can vary as changes occur in the predator/prey environment seasonally, from year to year, and geographically. Many of Montana's native mammals, raptors, and other species such as ravens prey upon sage grouse eggs, juveniles, and adults. Bull snakes are another species that can be an effective next predator. Invasive species like red fox and raccoon have expanded their range into sagebrush steppe communities and can impact the success of ground nesting birds. The quality and quantity of the sagebrush habitat, the composition of the predator community, and weather patterns such as drought or severe winters likely determine both the annual and long-term carrying capacity for sage grouse. Sage grouse populations in Montana appear to cycle from low to high numbers over a 10-year period, and these trends continue under the current combination of habitat, predation, and weather influences.

The composition and abundance of various avian and mammalian predator species has changed, and continues to change, since the termination of widespread predator control activities in the early 1970s. Changes in predator population composition and numbers may hold grouse numbers below their biological potential in some locations, even in areas characterized by largely unfragmented habitat.

Habitat fragmentation at the broad scale, which alters spatial relationships of remaining stands of sagebrush, potentially reduces the quantity of habitat. At the nest-site level, degradation of habitat through improper management can reduce the quality of sagebrush stands for nesting, most commonly by reducing the grass and forb understory. Both forms of habitat degradation can increase vulnerability of grouse and nests to the existing predator community, may alter the predator community, or both. Mammalian predator populations in degraded habitats often shift toward species that are smaller and more numerous (red fox, raccoon, striped skunk) and away from species that have evolved with sage grouse (coyote, badger). Similar shifts in mammalian predator communities can also accompany intensive predator control programs, e.g., red fox numbers can increase when coyote populations are controlled. Furthermore, certain avian species such as gulls and ravens may have expanded their range, and their foraging behavior can potentially impact either nest success or juvenile survival rates in certain localities.

Intensive predator control programs can influence predator numbers at the local level, e.g. coyote control for livestock production and red fox and skunk trapping to protect upland nesting ducks. The practice is expensive, and the benefits are generally considered to be short-term because populations of most predators rebound rapidly after control stops. To date, predator control seldom has been recommended for North American prairie grouse for several reasons (Schroeder and Baydack, 2001). Nesting often is dispersed over vast areas, greatly increasing costs of control programs. The long-term biological consequences of predator control are poorly 
understood and may actually be counterproductive under some circumstances. Finally, many potential predators of sage grouse are now legally protected, certain control methods such as poisons have been prohibited, and public attitudes towards predator control have changed (Messmer et al. 1999). However, if land use changes continue to degrade sagebrush habitats and the impacts of predators are shown to negatively impact sage grouse populations, direct predator control actions may assume greater management importance (Nelson 2001).

Certain vital rates such as adult hen survival, nest success rates, and juvenile recruitment drive sage grouse population dynamics. Attempting to modify these vital rates to increase populations through either direct predator control actions or by manipulating habitat to indirectly control predation rates should be evaluated in terms of cost effectiveness and efficiency. The influence of weather patterns on these same vital rates should likewise be integrated into these discussions.

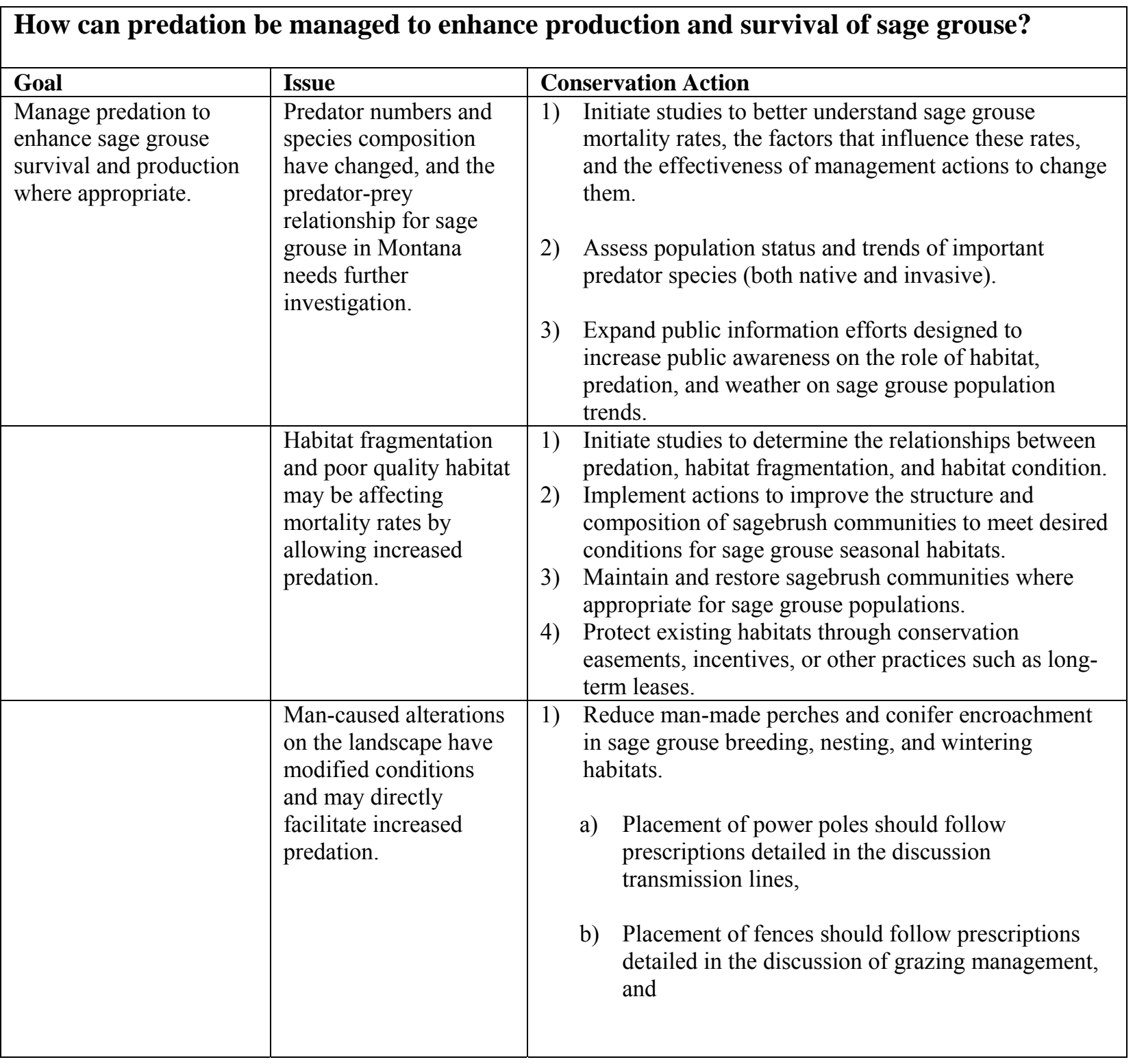




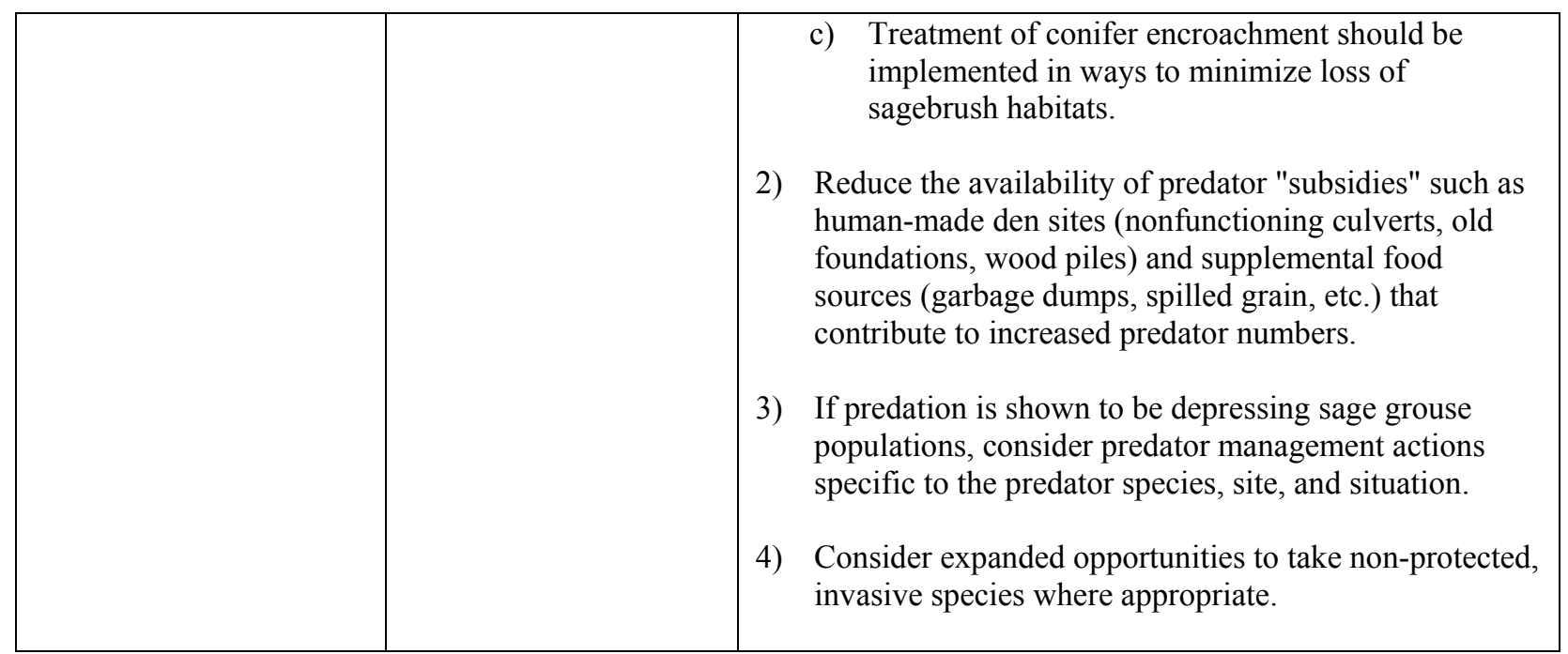

\section{Recreational Disturbance of Sage Grouse}

Sage grouse are sensitive to disturbance at breeding leks, at nest sites, and in critical wintering habitats. Human activity in these habitats may intentionally focus on sage grouse (lek viewing, monitoring, photography, etc.), or may be incidental to other recreational activities (OHV use, hiking, skiing, horseback riding, etc.). Disturbances can be diminished or minimized at critical times and on seasonal ranges by concentrating use at designated times of year or day, restricting activities within 1.5 miles of leks (Joslin and Youmans 1999), and/or allowing certain types of use only at designated sites, e.g. viewing, photography at leks.

Monitoring sage grouse populations and habitats is essential at leks and other critical habitats. Other multiple use activities also may disturb leks and other habitats. Recreational and monitoring activities should be considered cumulatively with other activities as part of assessing overall levels, effects, and approaches for managing human disturbance of sage grouse. Hunting as a recreational activity does not concentrate human use on seasonal ranges.

\begin{tabular}{|c|c|c|}
\hline \multicolumn{3}{|c|}{$\begin{array}{l}\text { How can we continue to provide sage grouse viewing and other recreational opportunities }{ }^{1} \\
\text { while minimizing impacts to sage grouse and sagebrush habitats? }\end{array}$} \\
\hline \multicolumn{3}{|c|}{\begin{tabular}{|l|l|l} 
GOAL & ISSUE & CONSERVATION ACTIONS \\
\end{tabular}} \\
\hline $\begin{array}{l}\text { Minimize the impacts of } \\
\text { recreational viewing of } \\
\text { sage grouse at leks. }\end{array}$ & $\begin{array}{l}\text { Citizens should be able } \\
\text { to view and photograph } \\
\text { sage grouse breeding } \\
\text { displays. However, } \\
\text { viewing may disturb } \\
\text { breeding activities, } \\
\text { displace leks, and } \\
\text { reduce reproductive } \\
\text { success. }\end{array}$ & $\begin{array}{l}\text { 1) Agencies should document leks where recreational } \\
\text { viewing is occurring. } \\
\text { 2) Working together, the agency(ies) and interested public } \\
\text { should determine whether or not management of } \\
\text { viewing is needed to reduce disturbance of leks. } \\
\text { 3) Educational materials should be developed and } \\
\text { provided to the public indicating the effects of } \\
\text { concentrated recreational activities and the importance } \\
\text { of seasonal ranges to sage grouse. }\end{array}$ \\
\hline
\end{tabular}




\begin{tabular}{|c|c|c|c|}
\hline & $\begin{array}{l}\text { Management of lek } \\
\text { viewing may be } \\
\text { necessary. }\end{array}$ & 1) & $\begin{array}{l}\text { Establish viewing guidelines, i.e., distance, timing, } \\
\text { approach methods, signage, parking areas, and area } \\
\text { closures. } \\
\text { Designate particular leks for public viewing, and where } \\
\text { appropriate, restrict viewing and photography to } \\
\text { designated sites. } \\
\text { Determine, through the agency(ies) and the public } \\
\text { working together, whether or not other recreational } \\
\text { activities disturb leks, nesting, or winter habitats. }\end{array}$ \\
\hline $\begin{array}{l}\text { Minimize the impacts of } \\
\text { recreational activities } \\
\text { unrelated to sage grouse } \\
\text { viewing. }\end{array}$ & $\begin{array}{l}\text { Types of recreation } \\
\text { other than lek viewing } \\
\text { may affect sage grouse. }\end{array}$ & 1) & $\begin{array}{l}\text { Reduce disturbance of sage grouse and degradation of } \\
\text { sagebrush habitats through use of site-specific } \\
\text { monitoring, and where appropriate, develop seasonally } \\
\text { restrictive public access to specific lek, nesting, and } \\
\text { winter habitats. } \\
\text { Consider sage grouse needs when developing roads and } \\
\text { OHV management plans. } \\
\text { Develop and provide educational materials to the } \\
\text { public describing effects of concentrated recreational } \\
\text { activities and the importance of seasonal ranges to sage } \\
\text { grouse. } \\
\text { Encourage recreationists to avoid continuous or } \\
\text { concentrated use within } 1.5 \text { miles }{ }^{1} \text { of leks from } 15 \\
\text { March to } 15 \text { May. } \\
\text { Issue special use permits for certain activities with } \\
\text { distance and timing restrictions to maintain the } \\
\text { integrity of breeding habitat. } \\
\text { Discourage concentrations of hunters on critical } \\
\text { seasonal habitats, e.g., during late big game seasons, } \\
\text { when sage grouse are present. }\end{array}$ \\
\hline
\end{tabular}

${ }^{1}$ Recreational hunting is discussed elsewhere under separate conservation actions.

\section{Roads and Motorized Vehicles}

Roads throughout Montana have a variety of impacts on sage grouse and their habitats. Vehicle use on federal and state lands, both on and off roads, has increased significantly over the past few years and is impacting habitat quality (Mattise 1995). As documented in a Montana Chapter of Wildlife Society Report (Joslin and Youmans 1999), vehicles do impact wildlife. Severity of impacts may be directly related to the amount of vehicle travel occurring. For example, the impact from an interstate highway through sagebrush-grassland could have a particularly devastating effect on sage grouse, whereas the impact from small amounts of motorized crosscountry travel occurring in the same area could be of little consequence to sage grouse during non-nesting or other non-critical time periods. 
As human population growth continues in southwestern Montana, pressure to subdivide land may further conflict with sage grouse. An increase in number of roads will cause continued habitat fragmentation and loss and a potential decline and/or shift in populations. In addition, a potential increase in oil and gas exploration and production in eastern Montana will substantially increase the number of roads/2-tracked roads. Indirect impacts on wildlife and wildlife habitat from road development and use during exploration and production includes trails, 2-track, bladed, and graveled roads. These impacts have been well documented for a variety of development projects (Trombulak and Frissell 2000) and include habitat fragmentation and direct loss of birds due to vehicles, stress, displacement, and increased hunting pressure. Roads also may affect an animal's reproductive success (Gutzwiller 1991). An increase in roads and other cross-country travel also contributes to the spread of noxious weeds and an overall decrease in wildlife habitat, including sage grouse habitat.

\section{How can existing and future roads be managed to minimize road-related disturbance, loss of habitat, degradation of habitat, and mortality of sage grouse?}

\begin{tabular}{|c|c|c|}
\hline Goal & Issue & Conservation Actions \\
\hline $\begin{array}{l}\text { Avoid further } \\
\text { fragmentation and/or loss } \\
\text { of critical sage grouse } \\
\text { habitats due to road- } \\
\text { related disturbances and } \\
\text { the cumulative effects of } \\
\text { roads. }\end{array}$ & $\begin{array}{l}\text { Roads may increase } \\
\text { sage grouse mortality } \\
\text { through collisions with } \\
\text { vehicles, displacement } \\
\text { because of human } \\
\text { disturbance, or other } \\
\text { factors. }\end{array}$ & $\begin{array}{l}\text { 1) Identify, map, quantify, and evaluate impacts of } \\
\text { existing roads, including 2-tracks, in relation to known } \\
\text { lek locations and sage grouse winter ranges. } \\
\text { 2) Consider impacts to sage grouse when designing new } \\
\text { roads and modifying existing roads. } \\
\text { 3) Consider seasonal use restrictions or signing to avoid } \\
\text { disturbance of critical sage grouse habitats. } \\
\text { 4) Consider the use of speed bumps where appropriate to } \\
\text { reduce vehicle speeds near leks, e.g., during oil and } \\
\text { gas development. } \\
\text { 5) Manage on-road travel and OHV use in key grouse } \\
\text { areas to avoid disturbance during critical times, e.g., } \\
\text { winter and nesting periods. } \\
\text { 6) Plan or permit organized events to avoid increased } \\
\text { traffic and impacts to sage grouse. } \\
\text { 7) Manage motorized and mechanized travel to minimize } \\
\text { impacts to sage grouse and their habitat by developing } \\
\text { standards for future roads to give to BLM, FS, BIA, } \\
\text { state, county, and private parties. } \\
\text { 8) Manage motorized and mechanized travel to minimize } \\
\text { impacts to sage grouse by increasing enforcement of } \\
\text { existing OHV and travel management plans. } \\
\text { Provide educational opportunities for users of OHVs } \\
\text { dealing with the possible effects they may have on sage } \\
\text { grouse. }\end{array}$ \\
\hline
\end{tabular}




\begin{tabular}{|c|c|c|c|}
\hline & $\begin{array}{l}\text { Roads and their } \\
\text { associated disturbances } \\
\text { and cumulative effects } \\
\text { contribute to the loss of } \\
\text { habitat and declining } \\
\text { sage grouse } \\
\text { populations. }\end{array}$ & $\begin{array}{l}\text { 4) } \\
\text { 5) } \\
\text { 6) }\end{array}$ & $\begin{array}{l}\text { Develop a transportation management plan across } \\
\text { ownership boundaries in critical sage grouse habitats. } \\
\text { Participate in travel planning efforts and educate the } \\
\text { general public about the impacts of roads on sage } \\
\text { grouse and critical habitats. } \\
\text { Consider buffers, removal, realignment, or seasonal } \\
\text { closures where appropriate to avoid degradation of } \\
\text { habitat. } \\
\text { Re-vegetate closed roads with plant species beneficial } \\
\text { to sage grouse. } \\
\text { Close and re-vegetate travel ways in sage grouse } \\
\text { habitats where appropriate. } \\
\text { Provide sage grouse habitat information during the } \\
\text { planning phases of transportation development, } \\
\text { working with, e.g., MDOT, FHWA, industry, } \\
\text { counties, etc. }\end{array}$ \\
\hline
\end{tabular}

\section{Vegetation}

Sage grouse require large expanses of sagebrush habitats with healthy, diverse understories of grasses and forbs. In some areas, past management of rangelands has altered the density, structure, and composition of sagebrush communities - sometimes creating a variety of conditions that do not meet the desired condition described for sage grouse seasonal needs. Composition of grasses and forbs, condition and densities of sagebrush, and other habitat-related conditions vary across Montana and include extremes. Variation may result from environmental factors such as climate and/or land management practices, e.g., fire management, grazing, weeds, recreation etc. Restoring or enhancing sage grouse habitats requires diverse strategies. Disagreement among professionals often arises regarding the ecological role, or successional relationships, of "mature" or "decadent" stands of sagebrush, the need to manipulate sagebrush communities, method of control, and extent of treatment. Prior to sagebrush manipulation on public land, a thorough review by an interdisciplinary team should be conducted. To determine potential effects, the review should include an analysis of historic treatments on similar habitat nearest the area in question.

Sage grouse habitats in Montana face the risk of sagebrush removal by prescribed burning or herbicide application, or by conversion to cropland. Conserving sagebrush habitats on private and public lands is by far the most effective approach to assuring long-term maintenance of sage grouse abundance and distribution in Montana. Incentive-based, voluntary programs are available for protecting privately-owned sage grouse habitats from detrimental habitat conversion. In some areas, there are opportunities for planting cropland back to sagebrushgrassland habitat. It is important to note, however, sagebrush plantings are costly, can have a high failure rate, and may provide less effective habitat for sage grouse compared to native 
sagebrush habitats. Because of this, we view sagebrush-grassland planting as a secondary approach to sage grouse conservation.

\begin{tabular}{|c|c|c|}
\hline \multicolumn{3}{|c|}{$\begin{array}{l}\text { How can we manage the density, structure, and composition of shrubs, forbs, and grasses } \\
\text { to maintain the health of the community, enhance sage grouse habitats, and meet the } \\
\text { needs of other species and human uses? }\end{array}$} \\
\hline Goal & Issue & Conservation actions \\
\hline \multirow[t]{3}{*}{$\begin{array}{l}\text { Manage sagebrush } \\
\text { communities in a manner } \\
\text { that results in improved } \\
\text { health and no net loss of } \\
\text { sagebrush habitats. }\end{array}$} & $\begin{array}{l}\text { Conifer encroachment } \\
\text { reduces sagebrush } \\
\text { habitat. }\end{array}$ & $\begin{array}{l}\text { 1) Map and inventory areas believed to be impacted by } \\
\text { conifer expansion. } \\
\text { 2) If conifer encroachment is a concern, options for } \\
\text { treatment include: } \\
\text { a) prescribed fires when and where feasible, } \\
\text { b) remove trees mechanically when feasible, } \\
\text { and } \\
\text { c) apply herbicides when and where feasible. } \\
\text { 3) Reclaim and/or re-seed areas disturbed by treatments } \\
\text { when necessary. Include native forbs and grasses in all } \\
\text { reclamation and seeding activities. }\end{array}$ \\
\hline & $\begin{array}{l}\text { Key privately owned } \\
\text { sagebrush-grassland } \\
\text { habitats may be at risk } \\
\text { of manipulation. }\end{array}$ & $\begin{array}{l}\text { 1) Provide incentives for habitat conservation such as the } \\
\text { state-administered Landowner Incentive Program, } \\
\text { which provides an incentive payment to private } \\
\text { landowners for protecting sagebrush habitats from } \\
\text { plowing, herbicides, and burning. } \\
\text { 2) Promote sagebrush-grassland habitat conservation } \\
\text { through USDA programs. } \\
\text { 3) Purchase conservation easements from interested } \\
\text { landowners, which protect habitat values. }\end{array}$ \\
\hline & $\begin{array}{l}\text { Information regarding } \\
\text { sagebrush distribution } \\
\text { is incomplete. }\end{array}$ & $\begin{array}{l}\text { 1) Identify the remaining breeding and winter areas for } \\
\text { sage grouse. } \\
\text { 2) Improve the classification of sagebrush cover to } \\
\text { distinguish density and species. } \\
\text { 3) Complete a mid- to broad scale assessment to identify } \\
\text { conservation priorities across the state. }\end{array}$ \\
\hline
\end{tabular}




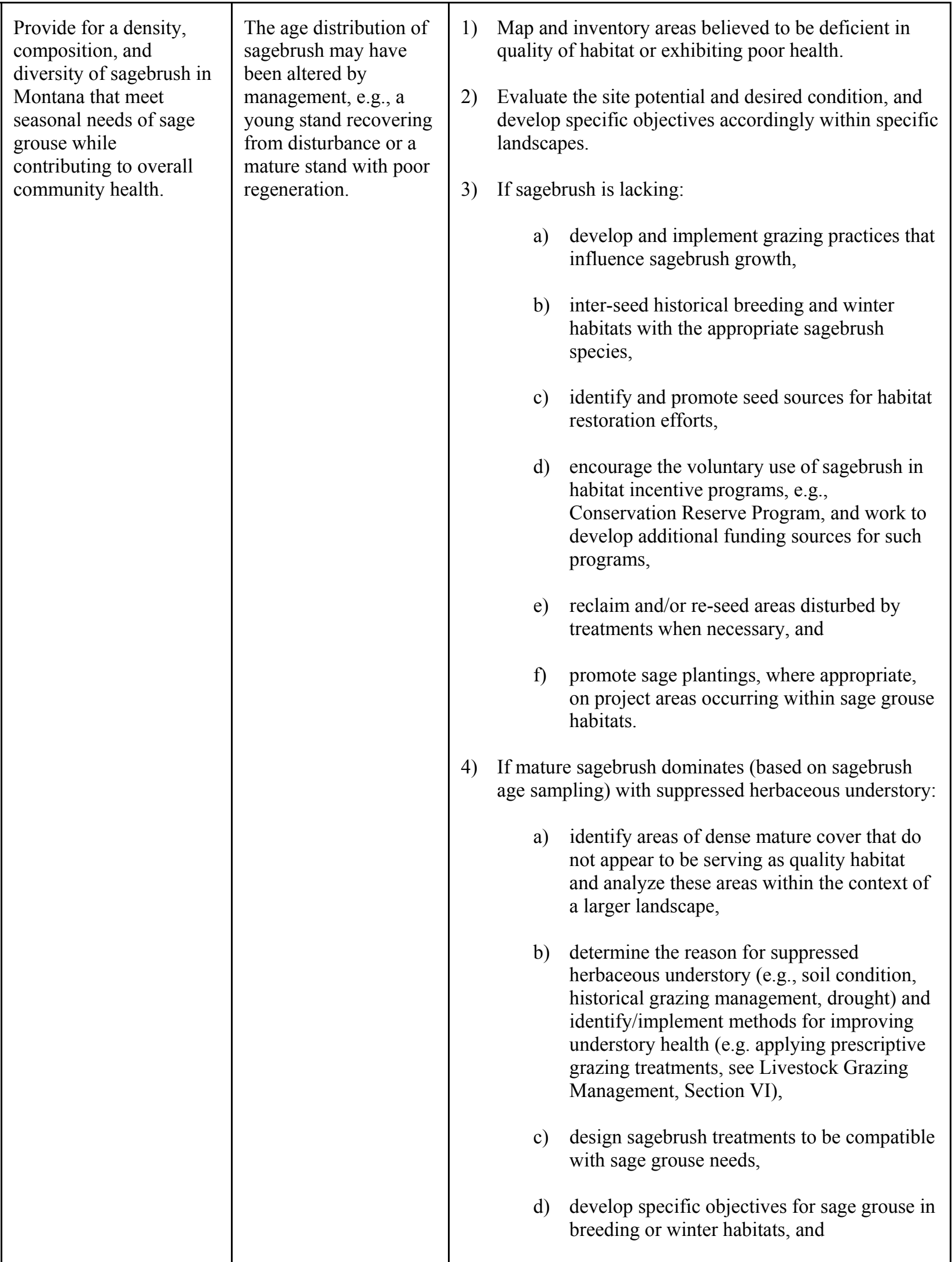




\begin{tabular}{|c|c|c|c|}
\hline & & & $\begin{array}{l}\text { e) if sagebrush treatment is deemed appropriate, } \\
\text { interrupt seral stages within the appropriate } \\
\text { patch size using the appropriate method, e.g., } \\
\text { brush beating, chaining, chemical means, } \\
\text { prescribed fire, etc., compatible with local } \\
\text { conditions. }\end{array}$ \\
\hline $\begin{array}{l}\text { Within the context of } \\
\text { improving seasonal } \\
\text { habitats, maintain or } \\
\text { improve vegetative } \\
\text { quality and quantity of } \\
\text { the understory in all } \\
\text { breeding habitats of sage } \\
\text { grouse. }\end{array}$ & $\begin{array}{l}\text { The plant community } \\
\text { has been altered and } \\
\text { lacks a diverse } \\
\text { herbaceous understory. }\end{array}$ & 1) & $\begin{array}{l}\text { Map and inventory areas believed to be important sage } \\
\text { grouse breeding habitats. } \\
\text { Evaluate the site potential and desired condition } \\
\text { within the context of a larger landscape. } \\
\text { Develop and implement techniques to increase } \\
\text { herbaceous diversity and density in sagebrush-steppe } \\
\text { within ecological limits. } \\
\text { Ensure that grazing practices allow plants to grow to } \\
\text { seed ripe on a rotational basis. } \\
\text { Adjust livestock grazing management when necessary, } \\
\text { e.g., season of use/projects, to promote forb } \\
\text { establishment and recruitment. } \\
\text { Identify large areas of introduced plant species, e.g., } \\
\text { crested wheat, and determine if restoration efforts are } \\
\text { deemed appropriate. } \\
\text { Interseed appropriate breeding habitats with forbs as } \\
\text { identified by the specialists and affected interests. } \\
\text { If mature sagebrush dominates with suppressed } \\
\text { herbaceous understory: } \\
\text { a) identify areas of dense mature cover that do } \\
\text { not appear to be serving as quality habitat } \\
\text { and analyze these areas within the context of } \\
\text { a larger landscape, } \\
\text { restoration efforts. } \\
\text { b) design sagebrush treatments to be compatible } \\
\text { with sage grouse needs, } \\
\text { c) develop specific objectives for sage grouse in } \\
\text { breeding or winter habitats, and } \\
\text { using the appropriate method, e.g., brush } \\
\text { beating, chaining, chemical means, } \\
\text { prescribed fire, etc., compatible with local } \\
\text { ditions. }\end{array}$ \\
\hline
\end{tabular}




\begin{tabular}{|c|c|c|}
\hline & & $\begin{array}{l}\text { 10) Identify landowner incentives and additional funding } \\
\text { sources to enhance existing programs, e.g., enhance } \\
\text { CRP. } \\
\text { Protect/enhance riparian areas to encourage succulent } \\
\text { vegetation and re-establishment of shrubs when lacking. }\end{array}$ \\
\hline & $\begin{array}{l}\text { Residual understory is } \\
\text { lacking in sagebrush } \\
\text { stands, mainly in } \\
\text { breeding habitats. }\end{array}$ & $\begin{array}{l}\text { 1) Develop incentives to promote desired habitat } \\
\text { conditions on private lands. } \\
\text { 2) Manage grazing by domestic livestock and wild } \\
\text { herbivores to retain and promote adequate residual } \\
\text { cover in all breeding habitats with an emphasis on } \\
\text { nesting areas. } \\
\text { 3) Ensure that grazing allotment plans include objectives } \\
\text { for sage grouse in sage grouse habitats. } \\
\text { 4) Monitor USFS/BLM/State allotment plans and } \\
\text { regulations, and make changes where necessary. } \\
\text { 5) Include native grasses in all reclamation and } \\
\text { restoration activities. }\end{array}$ \\
\hline $\begin{array}{l}\text { Where opportunities } \\
\text { allow, restore sage } \\
\text { grouse habitats lost to } \\
\text { plowing. }\end{array}$ & $\begin{array}{l}\text { Sagebrush-grassland } \\
\text { habitats, important to } \\
\text { sage grouse, have been } \\
\text { converted to cropland. }\end{array}$ & $\begin{array}{l}\text { Work with landowners to re-establish sagebrush- } \\
\text { grassland habitats through programs such as the } \\
\text { Upland Game Bird Habitat Enhancement Program or } \\
\text { CRP. }\end{array}$ \\
\hline
\end{tabular}

\section{Managing Other Wildlife in Sage Grouse Habitats}

Wild ungulates and other native herbivores, e.g., prairie dogs, may negatively affect habitats upon which grouse depend. Wild herbivores can contribute to the reduction of shrub canopy and/or herbaceous understory in nesting and brood-rearing habitats. Wild ungulates most often affect habitats of limited size within a landscape that includes streamsides and wet meadows that under most conditions provide an abundance of forbs and insects needed by sage grouse broods. These areas become increasingly important as dry conditions typically progress through summer.

Other land uses can compound the effects on areas of concentration by wild ungulates and other native herbivores. These conditions are especially important to address during periods of drought. Any attempt to resolve potential conflicts from wildlife use in sage grouse habitats depends on the knowledge and cooperation of local landowners and resource managers. Where evidence of adverse impacts by wild ungulates or other native herbivores is available, obtaining quantitative, site-specific measurements of vegetation conditions is paramount to assure that assessments are objective, and causes are accurately determined. 


\section{How can sage grouse habitat be maintained where the effects of other wild herbivores (ungulates) are reducing the quality of the site for use by sage grouse?}

\begin{tabular}{|c|c|c|}
\hline Goal & Issue & Conservation Action \\
\hline $\begin{array}{l}\text { Manage for wild } \\
\text { herbivore populations } \\
\text { commensurate with the } \\
\text { capability of sagebrush } \\
\text { communities to sustain } \\
\text { sage grouse, other } \\
\text { sagebrush dependent } \\
\text { species, and other land } \\
\text { use objectives. }\end{array}$ & $\begin{array}{l}\text { High concentrations of } \\
\text { wild herbivores in } \\
\text { localized areas may } \\
\text { reduce habitat } \\
\text { effectiveness for sage } \\
\text { grouse. }\end{array}$ & $\begin{array}{l}\text { 1) Identify and map key sage grouse habitats where other wild } \\
\text { herbivores are having significant impacts. } \\
\text { 2) Establish an inventory and vegetative monitoring schedule } \\
\text { to quantitatively determine the extent of the effects in key } \\
\text { areas. } \\
\text { 3) Determine seasons of expected use and assess the potential } \\
\text { impact to sage grouse habitat. } \\
\text { 4) Develop plans that keep ungulate population levels } \\
\text { consistent with the sites capability to support them. }\end{array}$ \\
\hline $\begin{array}{l}\text { Provide for an adequate } \\
\text { amount of functioning } \\
\text { riparian and wetland } \\
\text { habitat during critical } \\
\text { periods such as brood } \\
\text { rearing. }\end{array}$ & $\begin{array}{l}\text { Wetlands and other } \\
\text { riparian habitats may } \\
\text { be vulnerable to } \\
\text { overuse by wild } \\
\text { herbivores on some } \\
\text { sites. This can } \\
\text { sometimes be } \\
\text { exacerbated seasonally, } \\
\text { during droughts, and/or } \\
\text { by other land use } \\
\text { practices. }\end{array}$ & $\begin{array}{l}\text { 1) Identify levels of use by wild herbivores in affected } \\
\text { riparian areas. } \\
\text { 2) Identify other land use practices occurring in riparian } \\
\text { habitats. } \\
\text { 3) Assess current management practices in respect to findings. } \\
\text { 4) Determine whether management changes are needed. } \\
\text { 5) Have drought management plans in place to allow for the } \\
\text { rapid implementation of alternate management strategies. }\end{array}$ \\
\hline
\end{tabular}




\section{SECTION VII: ASSESSMENT, MONITORING, AND RESEARCH NEEDS}

\section{HABITAT ASSESSMENT AT MULTIPLE SCALES}

\section{Purposes and Limitations}

We designed a framework for habitat analysis to facilitate and standardize sage grouse habitat assessments in a manner that complements management direction in the Montana Sage Grouse Conservation Plan. Overall goals achieved by the habitat assessment process will be to (1) protect and maintain existing suitable habitats, (2) improve degraded habitats to suitable conditions, and (3) restore habitats to suitable conditions, where most feasible and important for long-term recovery.

Specifically, the framework describes a habitat assessment process that can be used to:

- Identify important remaining sage grouse habitat areas and priority habitat restoration areas.

- Evaluate and document existing sage grouse habitat suitability and habitat restoration needs.

- Assist in evaluating land uses on public lands that may affect sage grouse habitat conditions or habitat restoration efforts.

- Assist in evaluating attainment of pertinent land use plan objectives.

This assessment framework should be used for sub-basin reviews, watershed analyses, standards and guides evaluations (S\&G), Land Use Plan (LUP) evaluations, or any proposed projects that might affect existing or potential sage grouse habitat. This framework can be applied to a wide range of environmental conditions. It must be flexible and can be modified or refined according to local conditions; a certain degree of professional judgment will be required in its application.

This framework does not address potential land uses that may directly affect birds or their behavior and use of areas, e.g., transmission line mortalities, structures near leks, or wintering areas that may provide perch sites for raptors.

\section{Using the Assessment Framework}

This assessment framework allows considerable flexibility in data type and detail depending on local needs. If sage grouse habitats are a concern, Connelly et al. (Monitoring of greater sage grouse habitats and populations, in press) provides recommendations about the preferred techniques for measuring sage grouse habitat characteristics. Assessment field worksheets (see the Appendix) offer options for quantitative or qualitative data collection. While this flexibility is provided, biologists are encouraged to initially quantify all measurements to calibrate their visual estimation abilities. Site evaluation aids such as photo guides are being developed to assist in visual evaluations. In addition, biologists should quantify their evaluations if issues for an area are complex or controversial or if management decisions to manipulate vegetation are under consideration. Other information such as livestock utilization rates and patterns of use are also important to have in these situations. By allowing for qualitative assessments, particularly for lower priority sites, more time and effort can be concentrated on in-depth assessments on the 
more complex areas. Random selection of evaluation sites is not required in all situations but this approach may be needed in some cases. Most often, other available data can be used in conjunction with the evaluation process.

As assessments are completed, information will be summarized at the local level. Habitat assessment progress will be collated on a statewide basis annually, concurrently with updating the sage grouse habitat-planning map. This reporting process and a GIS-based data management system will be developed and maintained during implementation of the conservation plan.

Sage grouse require large areas of sagebrush to survive, and we have considerable knowledge of their habitat requirements compared to other species associated with sagebrush steppe. In some cases, other species that use sagebrush have different habitat needs than what we have outlined for sage grouse. As needed, we encourage land managers to address the unique, additional habitat needs of other sagebrush-associated species.

This assessment is intended for use in a step-down/hierarchical manner. It primarily provides guidance at the mid-scale (sub-basin) and fine scale (watershed, project, or site-specific) levels. Regional or broad scale assessments of sage grouse population and habitat data include information generated at the regional and state level. Regional vegetation maps, e.g., GAP data, should be used to identify habitat goals within the context of historical and existing sage grouse distribution.

\section{MID-SCALE INFORMATION AND ASSESSMENT USE}

\section{The Mid-Scale Unit}

We intend sub-basin or ecoregion reviews to provide an understanding of how management activities in sub-basins fit with the broad scale ecosystem and public land management emphasis. Landscape characteristics that should be measured include patch size, habitat quality, connectivity (availability of corridors connecting patches), amount of edge, and distance between habitat patches. Detail about vegetation characteristics will be added at the watershed or sitespecific levels as needed. Aerial photos, satellite imagery, and digitized maps can be used to measure the size and juxtaposition of these habitats (Homer et al. 1993). Remote sensing technology often forms the basis for inventorying, evaluating, and monitoring rangeland resources (Tueller 1989, Anderson and Gutzwiller 1994). Sage grouse source habitats, crucial habitats, and birds' seasonal movement patterns must be well understood to adequately assess habitats in the ecoregion. Once these data have been acquired and delineated on maps, the size and quality of the available habitats can be measured over the landscape.

For non-migratory populations, seasonal habitats should be well interspersed with no major barriers, e.g., reservoirs or urban areas, between habitats. These areas (sagebrush uplands, mesic areas) can be identified by aerial photographs, satellite imagery, or field inspection and mapping. In general:

- breeding habitats may be about $23 \mathrm{~km}^{2}\left(9 \mathrm{mi}^{2}\right)$ (Wallestad and Pyrah 1974)

- summer habitats may range from 0.4 to $0.9 \mathrm{~km}^{2}$ (.2 to $.3 \mathrm{mi}^{2}$ )in Montana (Wallestad 1971) to $28 \mathrm{~km}^{2}$ (11 $\left.\mathrm{mi}^{2}\right)$ in Colorado (K. P. Reese, unpublished data) 
- winter ranges may vary from 11 to $31 \mathrm{~km}^{2}$ (4.2 to $12 \mathrm{mi}^{2}$ ) (Wallestad 1975).

For migratory populations, grouse may use an area the size of the state of Rhode Island on an annual basis, and these movements may vary depending on annual precipitation (Connelly 1982, Fischer et al. 1996). However, within this large area, there are specific seasonal habitats used by these birds each year. These habitats may be disjunct, but corridors dominated by sagebrush should connect adjacent seasonal ranges. These ranges may vary in size, but generally breeding habitats will be 150 to $>600 \mathrm{~km}^{2}$ ( 58 to $>230 \mathrm{mi}^{2}$ ) (Leonard et al. 2000, J. W. Connelly, unpublished data), while summer range will be 0.5 to $7 \mathrm{~km}^{2}\left(0.2\right.$ to $\left.2.7 \mathrm{mi}^{2}\right)$.

\section{Mid-Scale Mapping}

Except for a few areas, accurate vegetation data to delineate existing and potential habitats at the sub-basin scale for sagebrush steppe are lacking. Until refined vegetation mapping data are available to discern important vegetation community differences, e.g., sagebrush canopy cover classes or density of sagebrush, reliance on more qualitative information for sub-basin planning needs is necessary.

At the mid-scale, land managers should develop a habitat planning map. The general purpose of this map will be to produce a relatively simple but widely applicable mid-scale map showing general habitat conditions within the ecoregion. Historical and current sage grouse distribution and other habitat and population information can be used to define the extent of habitat areas.

A sage grouse habitat planning map delineated at the mid-scale level should serve the following purposes:

- Assist land managers to quickly identify areas where sage grouse will be a primary concern, and those areas where sage grouse will not be an issue.

- Generally outline areas in need of restoration or improvement with respect to sage grouse habitat quality.

- Serve as a tool for planning and prioritizing fire suppression, fuels management, and prescription activities on public and private lands.

- Graphically portray the degree of sage grouse habitat fragmentation on the landscape.

- Provide mid-scale information at the statewide level on habitat conditions by merging ecoregion maps.

- Serve as an educational tool for explaining current sage grouse habitat conditions to resource users, cooperators, and interested parties.

Delineations that will be useful for conservation planning and mid-scale assessments include:

- Source habitats - areas identified as places where sage grouse populations are increasing or stable.

- Scarce habitats - areas that are limiting and are a priority for maintenance and restoration.

- Annual grasslands - areas dominated by annual or domestic grasses.

- Conifer encroachment areas - sagebrush or perennial grasslands with conifer encroaching into areas historically present as sage-grassland.

- Developed habitats - areas where vegetation manipulation or other activities have fragmented, degraded, or removed habitat. 
- Habitats at risk - areas with a reasonable, foreseeable development potential, e.g., conversion to cropland.

\section{FINE-SCALE INFORMATION AND ASSESSMENT USE}

\section{The Fine-scale Unit}

Generally, fine scale is defined geographically by watersheds (USDA/USDI 1995). In some cases, however, fine scale information for sage grouse may be more appropriately collated at the allotment level or pasture level depending on local needs. Allotments vary in size from as few as 40 acres to more than 250,000 acres. In most areas, particularly where small allotments dominate the landscape, watersheds should be the fine scale assessment unit. Where large allotments (>100,000 acres) dominate the landscape, however, they may be more appropriate as fine scale "management units." This flexibility allows for better integration of assessment and decisionmaking processes.

At the fine scale, it is important to identify land uses, vegetation characteristics, seasonal habitats, and the distribution, importance, and spatial context thereof. A variety of information sources should be reviewed at this level before going into the field to collect data. Habitat mapping efforts should be coordinated with state and federal agencies and local landowners.

At this stage, known historical and existing breeding, brood-rearing, and winter habitats can be identified and mapped, and sage grouse planning maps, delineated during the mid-scale assessment, can be further refined.

Preferably, most fine scale information should be displayed on GIS-generated maps, contingent on the availability of GIS support. Efforts to compile these data are ongoing throughout the state in cooperation with state and federal agencies. Fine scale mapping is still somewhat coarse but based on the best available information.

\section{Population Information}

Sage Grouse Lek Attendance Data.-Current and historical lek information can help to define areas of management and evaluation emphasis. Connelly et al. (2000b) recommends intensive habitat management for an area of $3.2 \mathrm{~km}(2 \mathrm{mi})$ around leks for nonmigratory populations and $18 \mathrm{~km}$ (11 miles) for migratory populations. Sage grouse in Montana are mostly nonmigratory (R. L. Eng, personal communication.), and until radio-tagging studies indicate otherwise, we will address habitat needs of sage grouse assuming they are nonmigratory. However, delineating nesting habitat using the 2-mile radius around an active lek must be applied with caution. This delineation may help define areas of management emphasis, but most remaining large tracts of sagebrush likely provide habitat. In addition, unless recent, intensive lek inventories have been completed, historic leks will be used to define these important existing breeding areas where sagebrush vegetation is still dominant on the landscape. Montana has large, remote areas of BLM-administered public lands that provide habitat but are difficult to inventory for sage grouse lek attendance. 
Other Historic and Current Observation Information.- - Historic and current information on sage grouse observations associated with nesting, brood-rearing, and wintering areas can be collated at the watershed scale, where available information from local citizens, agency files, and other sources should be used

\section{Vegetation and Habitat Information}

Breeding and Winter Habitats.-At this scale, sagebrush habitat availability and fragmentation patterns are important to consider in relation to the specific pasture or site being evaluated. Refining the sage grouse habitat-planning map is important at this stage. Broad delineations are based on readily available information. Efforts should be made to further delineate sagebrush steppe vegetation into the following categories, at the fine scale:

- Source habitats - areas identified as places where sage grouse populations are increasing or stable.

- Scarce habitats - areas that are limiting and are a priority for maintenance and restoration.

- Annual grasslands - areas dominated by annual or tame grass.

- Conifer encroachment areas - sagebrush or perennial grasslands with conifer encroaching into areas historically present as sage-grassland.

- Developed habitats - areas where vegetation manipulation or other activities have fragmented, degraded, or removed habitat, e.g., conversion of native habitat to cropland.

- Habitats at risk - areas with a reasonable, foreseeable development potential.

Late Brood-Rearing Habitat.-A number of moist or mesic vegetation communities provide late-brood-rearing habitat. In intermountain valleys, sage grouse generally will move to higher elevations as summer progresses, in search of succulent forbs and insects. For some areas, this movement can be fairly dramatic (Connelly et al.1988, Connelly et al. 2000b), and for other areas where nesting is occurring at higher elevations, this movement may not be far. Staffing constraints will limit ability to evaluate all potential late-brood-rearing habitats, so it is important at this stage to identify those of particular concern. Wet meadow complexes, sagebrush areas adjacent to agricultural fields, perennial streams, and lakes, ponds, or lakebeds with sagebrush in close proximity are typical late brood-rearing habitats because of the forb component and insect abundance.

At this scale, existing information for certain late brood-rearing habitats can be used to improve efficiencies. Many perennial streams in Montana have been evaluated for proper functioning condition (PFC) where files and photographs (videography in some cases) are available. In addition, water rights files contain pictures of developed and undeveloped water sources. This information should be reviewed to determine where field assessments are warranted. Existing information may be adequate for an assessment. Generally, it can be assumed that riparian areas in PFC or functioning-at-risk with upward trend are meeting or moving toward meeting the habitat needs for sage grouse.

General Land Use Information.--General public land use information can be helpful during the fine scale assessment, about such topics as:

- grazing allotment and pasture boundaries

- range improvement projects, e.g., spring development and pipelines 
- developed recreation areas

- utility corridors

- military sites

- elevational models and topographic maps

- historic wildfire data

- water rights files

- roads.

Ecological Site Data.--There are a variety of sources that can help delineate sage grouse seasonal habitats. Many exist as GIS data layers available through a variety of sources. Examples include but are not limited to, ecological site inventory (ESI), soils maps, vegetation maps, national wetland inventory (NWI), and riparian proper functioning condition (PFC) assessments.

\section{PROJECT OR SITE LEVEL ASSESSMENT}

\section{General Considerations}

Project or site level assessments will involve either qualitative or quantitative data collection depending on management or landowner needs. Site level procedures are used for a variety of purposes, such as general assessments to characterize current habitat conditions, project-specific evaluations that may be for an $S \& G$ evaluation of a grazing allotment, and proposed conservation easements, land exchanges, or prescribed fire projects.

Generally, allotment pastures will be a very important subset for any fine scale habitat assessment effort because:

- Livestock stocking rates and seasons-of-use for individual pastures can affect existing sage grouse habitats. Habitat conditions within a particular cover type can vary greatly between pastures.

- Livestock stocking rates and seasons-of-use for individual pastures can affect restoration potential and need to be considered in any restoration effort.

- Pastures are the analysis unit for rangeland S\&G's already ongoing throughout Montana, and grazing decisions are usually specific to individual pastures.

\section{Location and Timing}

Information collated at the fine scale should be used to help select sites. At this level, however, more detailed land use information should be reviewed before site selections, depending on needs. These information needs include, but are not limited to:

- area-specific fire and fire rehabilitation information

- livestock use information at the pasture level (class, stocking rates, season of use, utilization patterns)

- livestock watering sites in pasture or area of concern

- Ecological Site Inventory data

- rangeland health and PFC assessments

- other land uses in the area of concern that may affect habitat conditions. 
Once the additional area-specific information is assembled for the area of concern, evaluation sites can be selected. The number of evaluation sites selected will vary depending on the landscape complexity and level of potential conflict. These sites should be selected by an interdisciplinary team.

Table VII-1. Location and Timing of Evaluation

\begin{tabular}{|c|c|}
\hline Location & Timing \\
\hline \multicolumn{2}{|c|}{ Breeding Habitat } \\
\hline $\begin{array}{l}\text { - Sage grouse tend to nest more on flat to } \\
\text { slightly sloping lands. Evaluation sites } \\
\text { should not be located on steep slopes and } \\
\text { slopes }>40 \% \text { should not be considered } \\
\text { nesting habitat (J. Connelly, IDFG, } \\
\text { personal communication). } \\
\text { Evaluation sites will be located at least } \\
0.25 \text { mile from livestock watering areas. } \\
\text { Where possible, existing key use areas set } \\
\text { up for rangeland trend monitoring should } \\
\text { be used but only if they're representative. } \\
\text { Generally, sage grouse nest in big } \\
\text { sagebrush (Artemesia tridentata spp.). } \\
\text { Where present, representative evaluation } \\
\text { sites will be selected from the following } \\
\text { major categories: source habitats, scarce } \\
\text { habitats, annual grasslands, conifer } \\
\text { encroachment, developed habitats, habitats } \\
\text { at risk. }\end{array}$ & $\begin{array}{l}\text { Habitat evaluations must be done in May-June as } \\
\text { soon as broods are hatched. Timing within this } 2 \text { - } \\
\text { month time frame will vary depending on elevation } \\
\text { and annual climatic conditions. }\end{array}$ \\
\hline \multicolumn{2}{|c|}{ Late Brood-Rearing Habitat } \\
\hline $\begin{array}{l}\text { Important late brood-rearing sites identified } \\
\text { at the mid-level should be evaluated. A } \\
\text { variety of riparian, wetland and upland } \\
\text { communities may provide brood-rearing } \\
\text { habitat. } \\
\text { - Riparian areas and wet meadows located in } \\
\text { deep canyon areas will not be considered } \\
\text { as late brood habitat. } \\
\text { Evaluation sites will not be located in } \\
\text { designated livestock trailing stream } \\
\text { crossings or water gaps. }\end{array}$ & $\begin{array}{l}\text { Evaluations must be done July - October, unless an } \\
\text { adequate assessment can be done with existing } \\
\text { data. Where late brood-rearing habitat may be a } \\
\text { local habitat need or where controversy is } \\
\text { anticipated, biologists are encouraged to conduct } \\
\text { field assessments during the July-October period. }\end{array}$ \\
\hline \multicolumn{2}{|c|}{ Winter Habitat } \\
\hline $\begin{array}{l}\text { Low elevation, fragmented sagebrush areas } \\
\text { may provide important winter habitat. } \\
\text { - Winter and breeding habitat will overlap in } \\
\text { many areas. }\end{array}$ & $\begin{array}{l}\text { Evaluations can be done at any time since } \\
\text { sagebrush distribution, cover, and height are the } \\
\text { only factors of concern. }\end{array}$ \\
\hline
\end{tabular}

Annual climatic conditions need to be noted on field forms. Winter and spring precipitation can affect annual forb abundance and cover during the breeding season. 


\section{Using Worksheets and Evaluation Criteria}

Field evaluation worksheets (see Habitat Assessment Tools in the Appendix) for breeding, late brood-rearing, and winter habitats were developed using the Sage Grouse Management Guidelines (WAFWA; Connelly et al. 2000b).

For the purpose of standardizing evaluations, discrete ranges of numeric values were used for some habitat indicators to define suitable, marginal, and unsuitable habitat. It is important to note, however, that local habitat conditions, predominant plant species, and climate affect the potential of a particular site for supporting vegetative characteristics listed in the following matrices. Given this, habitat assessments may require local customizing to ensure the spectrum of potential for a site corresponds to habitat suitability criteria. For instance, $18 \mathrm{~cm}$ ( $7 \mathrm{inch}$ ) grass height may be achievable in some parts of Montana given the right weather conditions. In other areas, drought or shorter grass species may not support grass higher than 4 or 5 inches. Habitat variability across the sagebrush ecotones of Montana is substantial. It is therefore likely, matrices used in this section may not be suitable for all sage grouse habitats in Montana. Life history needs of sage grouse, however, remain the same (e.g. breeding habitat, brood rearing habitat, winter habitat). A mix of common sense and professional judgment is necessary when developing and applying suitability criteria to an area (Connelly et al. 2000b).

Within each matrix, suitable habitats meet the protective cover (sagebrush and herbaceous indicators) and food (forb indicators) needs of sage grouse while marginal and unsuitable habitat do not. Late brood-rearing and winter habitat matrices are mostly qualitative, emphasizing the need for succulent forbs during the summer and diversity of sagebrush densities and heights in the winter.

Quantitative field evaluation methods for the habitat indicators (canopy cover measurements, height measurements, etc.) are provided in the Appendix and in Connelly's publication (Monitoring sage grouse habitats and populations, unpublished manuscript). These methods are consistent with guidance developed by an interagency technical team for rangeland vegetation monitoring (USDI 1996).

It is important to note that not all the indicators need to be in the "suitable habitat" category for a site to be considered as suitable. For example, if a site had suitable breeding habitat conditions for all indicators except sagebrush canopy cover (cover was 30 percent), then a site rating of suitable would be appropriate. However, if a site had suitable habitat conditions for all indicators except sagebrush canopy (cover was only 5 percent), then this site would be unsuitable, because sage grouse must have sagebrush for nesting. Overall site evaluations will be based on best professional judgment with interdisciplinary involvement.

\section{Breeding Habitat}

Nesting cover and food availability are key components of breeding habitat suitability. Generally, sagebrush stands with a robust understory of grasses and forbs provide excellent sage grouse habitat. 
Table VII-2. Nesting And Early Brood-Rearing Habitat Features And Indicators For The Habitat-Assessment Matrix. For proper application of these habitat characteristics, see introductory remarks under "Using Worksheets and Evaluation Criteria," Section VII.

\begin{tabular}{|c|c|c|c|c|}
\hline $\begin{array}{l}\text { Habitat } \\
\text { Feature }\end{array}$ & Indicator & $\begin{array}{l}\text { Suitable } \\
\text { Habitat }\end{array}$ & Marginal Habitat & Unsuitable Habitat \\
\hline $\begin{array}{l}\text { Nesting } \\
\text { Cover }\end{array}$ & $\begin{array}{l}\text { Big sagebrush } \\
\text { canopy cover }\end{array}$ & $\begin{array}{l}\geq 15 \% \text { but } \leq \\
25 \%\end{array}$ & $10-14 \%$ or $26-35 \%$ & $<10 \%$ or $>35 \%$ \\
\hline $\begin{array}{l}\text { Nesting } \\
\text { Cover }\end{array}$ & $\begin{array}{l}\text { Big sagebrush } \\
\text { height }\end{array}$ & $12-30$ inches & $\begin{array}{l}10-14 \text { inches or } 31- \\
40 \text { inches }\end{array}$ & $\begin{array}{l}<10 \text { inches or }>40 \\
\text { inches }\end{array}$ \\
\hline $\begin{array}{l}\text { Nesting } \\
\text { Cover }\end{array}$ & $\begin{array}{l}\text { Big sagebrush } \\
\text { growth form }\end{array}$ & $\begin{array}{l}\text { Spreading form, } \\
\text { few if any dead } \\
\text { branches }\end{array}$ & $\begin{array}{l}\text { Mix of spreading and } \\
\text { columnar growth } \\
\text { forms present }\end{array}$ & $\begin{array}{l}\text { Tall, columnar } \\
\text { growth form with } \\
\text { dead branches }\end{array}$ \\
\hline $\begin{array}{l}\text { Nesting } \\
\text { Cover }\end{array}$ & $\begin{array}{l}\text { Herbaceous } \\
\text { perennial grass } \\
\text { and forb height }\end{array}$ & $\geq 7$ inches & $5-<7$ inches & $<5$ inches \\
\hline $\begin{array}{l}\text { Nesting } \\
\text { Cover \& } \\
\text { Food }\end{array}$ & $\begin{array}{l}\text { Perennial grass } \\
\text { canopy cover }\end{array}$ & $\geq 15 \%$ & $5-14 \%$ & $<5 \%$ \\
\hline $\begin{array}{l}\text { Nesting } \\
\text { Cover \& } \\
\text { Food }\end{array}$ & $\begin{array}{l}\text { Forb canopy } \\
\text { cover }\end{array}$ & $\geq 10 \%$ & $5-<10 \%$ & $<5 \%$ \\
\hline Food & Forb richness ${ }^{1}$ & High & Low & Very low \\
\hline
\end{tabular}

${ }^{1}$ Relative to ecological site descriptions.

At this time, it will be important to record any site potential considerations that affect suitability. There will be areas that have suitable sagebrush cover but soil conditions and/or dominant grasses provide for unsuitable nesting conditions, e.g., dominant grasses such as Sandberg's bluegrass (Poa sandbergii) may not have the growth form to meet perennial herbaceous height criteria. The evaluation worksheets provide for these notations, which will be very important later when evaluations are summarized at the project area level. Adequate justification as to site potential problems must be provided.

At least one field worksheet (see Habitat Assessment Tools in the Appendix) will be filled out for each of the major cover types present within the project area of concern. If the area of concern has more than one pasture, then at least one worksheet per cover type per pasture is required. 


\section{Late Brood-Rearing Habitat}

Food availability (forbs) in proximity to good escape cover are important habitat features of sage grouse brood-rearing areas. Healthy riparian, wet meadow and upland plant communities are important where such areas provide the brood-rearing habitat. Abundance, diversity, and availability of forbs are crucial. Agricultural fields with good escape cover nearby can provide important sage grouse brood-rearing habitat (Connelly et al. 2000b). In these cases, sagebrush cover on adjacent BLM-administered lands will be an important habitat indicator.

Table VII-3. Late Brood-Rearing Habitat Features And Indicators For The Habitat Assessment Matrix

\begin{tabular}{|c|c|c|c|c|}
\hline $\begin{array}{l}\text { Habitat } \\
\text { Feature }\end{array}$ & Indicator & Suitable Habitat & Marginal & Unsuitable Habitat \\
\hline Food & $\begin{array}{l}\text { Riparian and } \\
\text { wet meadow } \\
\text { plant } \\
\text { community }\end{array}$ & $\begin{array}{l}\text { Mesic or wetland } \\
\text { plant species } \\
\text { dominate wet } \\
\text { meadow or riparian } \\
\text { area }\end{array}$ & $\begin{array}{l}\text { Xeric plant species } \\
\text { invading wet } \\
\text { meadow or riparian } \\
\text { area }\end{array}$ & $\begin{array}{l}\text { Xeric plant species } \\
\text { along water's edge } \\
\text { or near center of wet } \\
\text { meadow }\end{array}$ \\
\hline $\begin{array}{l}\text { Cover and } \\
\text { Food }\end{array}$ & $\begin{array}{l}\text { Riparian and } \\
\text { wet meadow } \\
\text { stability }\end{array}$ & $\begin{array}{l}\text { No erosion evident; } \\
\text { some bare ground } \\
\text { may be evident but } \\
\text { vegetative cover } \\
\text { dominates the site }\end{array}$ & $\begin{array}{l}\text { Minor erosion } \\
\text { occurring and bare } \\
\text { ground may be } \\
\text { evident but } \\
\text { vegetative cover } \\
\text { dominates the site }\end{array}$ & $\begin{array}{l}\text { Major erosion } \\
\text { evident; large } \\
\text { patches of bare } \\
\text { ground }\end{array}$ \\
\hline Food & $\begin{array}{l}\text { Forb } \\
\text { availability in } \\
\text { uplands and } \\
\text { wetland } \\
\text { areas }\end{array}$ & $\begin{array}{l}\text { Succulent forbs are } \\
\text { readily available in } \\
\text { terms of distribution } \\
\text { and plant structure }\end{array}$ & $\begin{array}{l}\text { Succulent forbs are } \\
\text { available though } \\
\text { distribution is spotty } \\
\text { or plant structure } \\
\text { limits effective use }\end{array}$ & $\begin{array}{l}\text { Succulent forbs are } \\
\text { not available due to } \\
\text { site condition or plant } \\
\text { structure }\end{array}$ \\
\hline Cover & $\begin{array}{l}\text { Proximity of } \\
\text { sagebrush } \\
\text { cover }\end{array}$ & $\begin{array}{l}\text { Sagebrush cover is } \\
\text { adjacent }(<100 \\
\text { yards) to brood- } \\
\text { rearing area }\end{array}$ & $\begin{array}{l}\text { Sagebrush cover is } \\
\text { in close proximity } \\
(100-300 \text { yards }) \text { of } \\
\text { brood-rearing areas }\end{array}$ & $\begin{array}{l}\text { Sagebrush cover is } \\
\text { unavailable (> } 300 \\
\text { yards). }\end{array}$ \\
\hline
\end{tabular}

Field worksheets will be filled out for areas that were identified as important late brood-rearing areas during the watershed or fine scale review. Recent information, e.g., PFC assessment and photographs, should be used in conjunction with a field assessment and in some cases can be used instead of a field visit, where appropriate. However, availability of forbs during the summer and fall is the primary habitat feature of concern for these brooding areas, and site visits are encouraged. 


\section{Winter Habitat}

Sagebrush cover and availability during the winter are the most important habitat indicators for the food and cover needs of sage grouse.

Table VII-4. Winter Habitat Features And Indicators For The Habitat Assessment Matrix

\begin{tabular}{lllll}
\hline $\begin{array}{l}\text { Habitat } \\
\text { Feature }\end{array}$ & Indicator & Suitable Habitat & Marginal Habitat & Unsuitable Habitat \\
\hline $\begin{array}{l}\text { Cover and } \\
\text { Food }\end{array}$ & $\begin{array}{l}\text { Sagebrush } \\
\text { canopy } \\
\text { cover }\end{array}$ & $10-30 \%$ & $5-9 \%$ & $<5 \%$ \\
$\begin{array}{l}\text { Cover and } \\
\text { Food }\end{array}$ & $\begin{array}{l}\text { Sagebrush } \\
\text { height }\end{array}$ & $\begin{array}{l}\text { Normal height } \\
\text { relative to site } \\
\text { potential }\end{array}$ & $\begin{array}{l}\text { Hedged shrubs, } \\
\text { slightly shorter } \\
\text { relative to site } \\
\text { potential }\end{array}$ & $\begin{array}{l}\text { Severely hedged } \\
\text { shrubs and short } \\
\text { relative to site } \\
\text { potential }\end{array}$ \\
\hline
\end{tabular}

Field worksheets can be filled out at any time and should, in many areas, use the same data set as that collected for the breeding habitat matrix. Wintering areas identified at the watershed or fine scale should be evaluated. Breeding and winter habitat will overlap in many areas, so it is important to remember that sagebrush cover needs in these areas are slightly different in the winter than during the breeding season. An area with sagebrush canopy cover exceeding 30 percent may not provide suitable nesting habitat but may provide important, suitable winter habitat. Careful assessment and evaluation is required before any management decisions are made.

\section{Organizing Site Evaluations at the Project Area Level}

For many public land uses, e.g., livestock grazing permits and habitat restoration projects, organizing the site assessments for the project area will be needed. For small or vegetatively uniform pastures, one or two field evaluation sites will adequately characterize current habitat. However, for large and/or complex pastures, multiple site evaluations may be necessary.

It is important to remember that the purpose of these evaluations is to not only evaluate existing conditions but also provide information on restoration needs. An unsuitable rating for a pasture is not necessarily a "bad" evaluation or a negative reflection on management. For example, using this assessment process, a fire rehabilitation seeding with suitable grass and forb cover but unsuitable sagebrush cover would be classified as currently unsuitable sage grouse habitat. However, the habitat assessment would also indicate that the area may be a priority restoration site for sagebrush seeding. The fact that the grass and forb cover are in a suitable range also may indicate that livestock stocking rates and/or season-of-use would complement restoration goals and expenditure of restoration funds. 
At the fine scale, organizing evaluations by seasonal use periods (breeding, late brood-rearing, and wintering habitats), cover type and pasture is appropriate. Summary forms in the Appendix (Habitat Assessment Tools) are provided to help in this regard. 


\section{LEK MONITORING: GUIDELINES FOR AERIAL AND GROUND SURVEYS}

Following is the protocol for monitoring leks statewide. The survey form can be found in Lek Monitoring Tools in the Appendix.

\section{** RESPECT PRIVATE PROPERTY**}

Before surveying leks on private ground, obtain landowner permission for vehicle/foot access.

Lek ID\#: Regional code + unique number

I. Regional code, e.g., BLM map name $($ Angela $=\mathrm{AN})$ or County Code

II. Location (use appropriate Lek ID\# and convert all location data to a digital GPS format)

A. GPS location data

B. Township, Range, Section, $1 / 44^{1 / 4}$ section (NW NE: northwest $1 / 4$ of northeast $1 / 4$ )

C. Ownership - Public or Private

III. Date

A. Outside Survey Framework Dates - last week of March to first week of May

B. Optimum Survey Period - month of April

1. Maximum male attendance $-2^{\text {nd }}-3^{\text {rd }}$ week of April. (Peak male counts are generally observed 1-2 weeks after peak hen attendance.)

2. Maximum total numbers (males + females) $-2^{\text {nd }}$ week of April.

IV. Time of Day

A. Morning Period

1. Birds are most active from 30 minutes before sunrise -2 hours after sunrise

2. Optimum counts obtained from 15 minutes before sunrise -45 minutes after sunrise.

B. Evening Period

1. Bird activity is much more variable and thus morning surveys are preferred.

2. Optimum counts obtained from 15 minutes before sunset until dark.

V. Survey weather conditions (especially pertinent if trying to locate new grounds by listening from ground stations).

A. Sky Cloud Cover (Clear, Partly Cloudy, Overcast, Raining, Snowing)

B. Wind Speed (Beaufort Scale of $0(<1 \mathrm{MPH}$, smoke rises vertically), 1 (1-3 MPH, direction of wind shown by smoke drift), 2 (4-7 MPH, wind felt on face, leaves rustle, ordinary wind vane moves), 3 (8-12 MPH, leaves and twigs in constant motion, wind extends light flag), 4 (>13 MPH)). Do not run a listening route if wind speeds exceed Beaufort 3 (> $12 \mathrm{MPH})$.

C. Temperature $(\mathrm{C} / \mathrm{F})$

VI. Disturbance rating (can significantly impact the number of grouse in attendance)

A. Low - Grouse present on lek and actively displaying.

B. Moderate - Observer or predator presence resulting in reduced activity or partial flush. 
C. High - Eagle or coyote present in vicinity, no grouse displaying, fresh sign present.

VII. Count quality (High, Medium, Low). Parameters include date, time of day, numbers of times ground was visited, survey weather conditions, and disturbance rating

VIII. Survey Type

A. Trend: Surveys conducted on an annual basis utilizing either Block or Route coverage patterns.

1. Block: Survey unit is defined by distinct boundaries and survey coverage is complete for the geographic area. Surveys monitor both historic leks as well as newly established grounds. Sage grouse densities can be estimated for the geographic area.

2. Route: Survey route is predetermined and geographic coverage is linear.

Surveys monitor historic leks and as well as newly identified leks and are

typically done by vehicle. Densities of sage grouse cannot be estimated.

B. Incidental: Lek surveys are conducted 1) randomly on grounds not included in annual blocks or routes, or 2) in areas where activity is suspected but no previous surveys have been conducted.

IX. Survey Method

A. Aerial Methodology

1. Fly North-South transect lines with sun at back, surveying east to west.

2. Fly at a 100 to 300 -foot elevation above ground height.

3. Fly transect lines that are optimally $1 / 2$ mile apart.

4. Record:

a) GPS location

b) Status

c) Number of Males/Total Count

B. Vehicle/Foot (ground) Methodology

1. If unfamiliar with the location, drive to the lek location prior to the survey if possible. Locate a position where the entire lek can be viewed from the cab of the vehicle or a blind.

2. Count birds on lek from vehicle or blind, using binoculars or spotting scope, and remain at the site until an accurate count is obtained. Females may be difficult to observe, especially if they are using the periphery of the lek. If additional leks are to be checked during the same morning, remain at each lek only long enough to feel comfortable with the count obtained.

3. On leks where trends in male attendance are being assessed, more rigorous survey protocol must be followed to standardize sampling effort. These leks should be assessed: a) at the same time(s) in the breeding season each year, b) same time of day each year, and c) actual time spent counting males should be the same each year.

4. On leks of known locations (GPS coordinates) with no apparent activity, walk the ground to look for signs of activity: feathers, droppings, vegetation trampling. 
Listen and glass surrounding area to insure that the lek location has not shifted. Return again if activity is suspected.

5. When surveying a new area or checking for activity around a currently inactive lek, stop approximately every mile, shut off the vehicle, glass and listen for displaying birds. On calm days, grouse can be heard up to 1.5 miles away.

X. Lek Status
A. Active/Inactive/Unknown
B. Numbers of Grouse Present
C. Males/Females/Total

XI. Habitat Description/Condition

A. Land Cover Types - General land cover type description: percent of SagebrushGrassland, Introduced Pasture, and Cropland within 1 mile of lek. Categories: $<5$ percent $=1,5-50$ percent $=2,50-95$ percent $=3,>95$ percent $=4$.

B. Land Cover Status -- Has the amount of sagebrush cover changed between this year and last? $\mathrm{Y} / \mathrm{N}$, if $\mathrm{Y}$ then indicate percent change.

C. Residual Cover Status -- Indicate quality/quantity of the herbaceous cover as Good (good growth during previous year, no to light grazing, good residual cover), Average (moderate growth and/or grazing pressure, residual cover patchy), or Poor (previous growing season dry or heavy grazing pressure, little residual cover).

Montana Fish, Wildlife and Parks Regional Contacts (for compilation of annual lek survey data)

R-3: Kurt Alt

R-4: Tom Stivers

R-5: Jay Newell

R-6: Pat Gunderson

R-7: John Ensign

\section{RESEARCH NEEDS}

The importance of sagebrush communities to sage grouse is well documented in the literature (e.g., Connelly et al. 2000b). This plan details the qualitative and structural parameters of the sagebrush community and their importance to sage grouse on a seasonal basis. The plan also identifies sources of risk to sage grouse (see Section V), although it may overstate some factors and understate others. For the plan to garner broad-based support, a need remains to detail how sage grouse conservation efforts will benefit other wildlife and other resources users.

\section{Habitat and Population}

Habitat Fragmentation.--The crux of the plan is addressing habitat loss and fragmentation, including strategies to prevent and reduce fragmentation. We recognize the threat that fragmentation poses to maintaining viable grouse populations. Fragmentation has both temporal and spatial aspects. 
Temporally, we cannot assume the landscape will remain static. As land use or habitat changes occur, habitat becomes fragmented. At some level of fragmentation, habitat effectiveness is lost.

From a spatial perspective, we need to know: 1) effective patch size and 2) habitat interspersion and juxtaposition that meets habitat requirements and facilitates connectivity among groups. Effective patch size dictates the spatial extent of suitable habitat that will provide seasonal requirements, e.g., nesting, brood-rearing, and wintering. Such information could assist resource managers in managing habitat patches that meet seasonal or yearlong habitat requirements.

Available literature describes habitat characteristics conducive to breeding, nesting, brood rearing, and wintering at the fine scale. A better understanding of the spatial extent of suitable habitat patches at the mid-scale is needed.

Population Dynamics.--The two primary methods for determining population status and trend for sage grouse are lek surveys and information from harvested birds. These methods were never intended to provide estimates of population size. They can, however, provide reasonable estimates of population trend over time and an opportunity to identifying major causative factors that influence population trend. A rigorous monitoring protocol is needed to assess population status and trend at the fine and mid-scale.

\section{Specific Needs}

Following are research needs identified among the conservation actions listed in Section VI.

- Develop a monitoring strategy that will measure long-term statewide sage grouse abundance and distribution trends.

- Evaluate the consequences of using pesticides and herbicides on the herbaceous understory and insect availability.

- Evaluate the effects of hunting on sage grouse in Montana and what would constitute an optimal harvest rate.

- Complete a broad scale assessment to identify important areas requiring additional protection or conservation during land use planning and leasing of energy reserves.

- Provide for long-term monitoring of siting requirements to assess effects of current and future energy development on sage grouse.

- Assess sage grouse mortality rates, factors that influence them, and effectiveness of actions taken to reduce them.

- Determine relationships between predation, habitat fragmentation, and habitat condition.

- Evaluate impacts of existing roads, including 2-tracks, in relation to known lek locations and sage grouse wintering areas.

- Develop techniques to increase herbaceous diversity and density in sagebrush steppe. 


\section{SECTION VIII: COORDINATION AND OVERSIGHT}

\section{PLAN MONITORING, EVALUATION, AND ADAPTIVE IMPLEMENTATION}

The Montana Sage Grouse Conservation Plan establishes a process to achieve sage grouse management objectives and is intentionally adaptive in nature to meet unexpected or unknown situations. Plan implementation will be achieved through state and federal agency efforts and various local work groups, e.g., sage grouse work groups, watershed groups, coordinated resource management groups, etc. The state-level work group will continue to provide coordination, oversight, and review of local planning efforts.

Consistent documentation of data collection procedures and methodologies is necessary to ensure that monitoring results are comparable over time. Implementation groups along with local, state, and federal agencies will be responsible for documenting their accomplishments. Data and accomplishments will be reported annually to Montana Fish, Wildlife and Parks by the first of the calendar year. Soon after, state work group members will meet to summarize accomplishments, assess on-the-ground management actions, measure progress in resolving resource conflicts, identify additional data or conservation needs, and make recommendations for adjusting objectives or actions, if needed. This coordination will include appropriate consultation and cooperation with rangeland users, general public, landowners, academia, private and state organizations, and local, state, and federal agencies.

\section{LOCAL WORK GROUPS}

Critical to the success of the plan is active participation by local working groups. Local working groups will comprise a diversity of stakeholders who will use the Plan as a basis for identifying issues in the area and for developing and implementing creative solutions, taking into account local conditions. The solutions can be unique to the region and based on observations, knowledge, and experience of the stakeholder members, in coordination with scientific data and consistent with agency policies and programs.

A statewide coordinator will be responsible for assisting each local working group in developing and implementing appropriate conservation actions, facilitating the organization and recruitment of members, helping conduct and officiate working group meetings, resolving conflicts, producing educational material, and organizing media and public outreach for keeping the public informed of working group activities. As a start, eighteen months of funding has been acquired for this position that included contributions from BLM, FWP, and National Fish and Wildlife Foundation. A request for proposals for a local working group coordinator has been advertised. When hired, the coordinator contract will be administered through the Montana Wildlife Federation, with oversight by members of the statewide Montana Sage Grouse Work Group.

\section{Role}

The role of the local work groups is to adapt the plan to specific local areas to develop and implement strategies that will improve or maintain the sagebrush steppe and reduce or mitigate factors that may further reduce sage grouse habitats or populations. 
Mission Statement.-Each group should create a mission statement consistent with the goal of the statewide management plan and conservation strategies and with the role of the local work groups.

Guiding Principles.-To ensure that the plans will be in balance with social, cultural, and community values, the following four principles provide the framework to guide local work group efforts. Each local work group may determine additional principles and "ground rules" to improve the efficiency of group. The guiding principles are:

1) Conservation actions implemented for sage grouse will contribute to the overall health of sagebrush communities across the landscape.

2) Conservation strategies will integrate local, regional, and national needs for conservation planning.

3) Wildlife professionals, land managers, private landowners, and all others who have a stake in sagebrush communities will be tolerant, understanding, and respectful of other perspectives and focus on areas of common interest.

4) This plan is not intended to exclude any uses or activities or infringe on legally defined private property rights; rather, it serves to provide solutions to problems and address issues that negatively affect sage grouse and degrade sagebrush community health.

Scope of Authority.- The role of local work groups is to develop and implement strategies consistent with sage grouse and sagebrush habitat conservation. Implementation of strategies will be accomplished within the scope of agencies' existing policies and in voluntary cooperation with private landowners. Whereas work groups may influence agency policy, they cannot change agencies' policies nor mandate management strategies on private land.

\section{Organization}

Location and Time Frames.-It is anticipated that eleven local groups will be formed over a three-year period. Locations of the local groups were determined by a combination of factors including ease of accessibility, habitat type, identified issues, etc. The first three groups will begin within one year of the plan's adoption. Within a year of the start of the first groups, an additional three or four groups will begin, and within a year of that, another three or four groups will commence. Due to the long-term nature of the plan, we anticipate that local groups will be active for 10-20 years. 


\section{$\underline{\text { First Year }}$}

Town

Dillon

Broadus

Glasgow

\section{$\underline{\text { Second year }}$}

Winnett, Grass Range, Winifred

Miles City, Forsyth

Red Lodge

White Sulphur Springs

\section{$\underline{\text { Characteristics of Area }}$}

Meetings are currently underway.

Habitat quality issues exist.

Idaho work provides a foundation.

Coalbed methane is an issue.

Information is lacking about population, distribution, and habitat use.

Rangeland management issues, e.g. burning, exist. There are common issues with Wyoming and tribal governments.

Good sage grouse populations exist.

There is local interest.

Canadian populations associated with northern

Montana populations

There is the possibility of cooperative work with and tribal governments and parties in Alberta.

This is silver sagebrush country.

Good populations of sage grouse exist.

Good data is available.

Issues include rangeland conversion, burning, potential oil and gas development.

Good populations of sage grouse exist.

Data is fair.

There is local interest.

Issues include coal development, power plants, and mines.

There is an opportunity to work with tribal governments.

Good data are available.

Sage grouse population is stand-alone, isolated.

There is an opportunity to work with tribal governments.

Sage grouse population is isolated.

There is restoration potential. 
Third Year

Terry

Harlem, Chinook, Malta

Roundup, Ryegate

Jordan
Good populations of sage grouse exist.

Rangeland conversion (plowed) is an issue.

There is an active tribal wildlife program.

Good populations of sage grouse exist.

Fragmentation of habitat is an issue.

\section{Other Considerations}

Membership.-Membership in the local work groups is open to all interested parties but should include a balanced selection of local stakeholders. Initial invitations to the formation of the group may be by public announcements or personal contacts through appropriate referral sources. Some communities in Montana already have organized natural resource working groups that may be able to expand to include sage grouse conservation, thereby avoiding duplicated efforts. In addition, county extension agents, tribal governments, BIA, NRCS, professional societies, RACs, etc., may be incorporated to implement local conservation efforts.

Because efforts of the groups will require long-term commitments by the core members, the groups may want to identify criteria to recognize "core members" and allow "core members" a different degree of authority from general meeting attendees. This could be done at the discretion of each local group.

Funding.-Where needed, an initial two to three years of funding for the local groups will be provided through several sources including agencies and grants. After the initially-funded period, the local groups will be self-funded. Assistance in identifying sources of available monies will be provided through resource and support personnel as listed below.

Resources and Support.- Initial meetings will be chaired by a facilitator to ensure the group meetings are balanced and orderly and remain "on task." The facilitator will be available for meetings until the group begins to coalesce and his or her participation is no longer needed.

One or two agency staff members will be available at each meeting to provide technical support as needed. Their anticipated role is to provide biological information, clarify agency policies and programs, and contribute as a technical resource as needed.

Education.-We anticipate using academia, agency expertise, and state work group experience to bring local groups "up to speed" on the issues surrounding sage grouse conservation. 
Expectations.-Within two years. Local groups are expected to:

- Coordinate issue development with appropriate agencies.

- Develop action steps to implement the plan.

- Seek creative solutions.

- Identify priority areas through issue development.

- Have at least one project funded and implemented within two years.

- Provide a list of measurable results with a timeline.

- Provide a plan for monitoring results. 


\section{SECTION IX: ADDRESSING ENDANGERED SPECIES CRITERIA}

The US Fish and Wildlife Service (USFWS) recently adopted the Policy for Evaluation of Conservation Efforts When Making Listing Decisions, (PECE). This set of 15 criteria will be used by the USFWS, when reviewing this Plan, to determine: 1) the certainty that the conservation effort will be implemented and 2) the certainty the conservation effort will be effective. The strengths of ths Plan, as well as other state and federal planning efforts, including other factors, will be used by the USFWS to make a determination for listing the sage grouse under the Endangered Species Act.

This Montana sage grouse planning strategy was compiled and written by a group of agencies, organizations, and individuals as a collaborative effort, in a public forum. The Montana Sage Grouse Working Group, organized as part of this process, comprises all of the key entities necessary for developing an effective sage grouse conservation plan in Montana. The development and involvement of this group is, in and of itself, a significant step toward sage grouse conservation in Montana. Each of the group's participants are aware of the important issues associated with sage grouse and their habitats. Within the Plan, the managing agencies have spelled out their authorities and mandates and have made commitments to sage grouse conservation within their respective areas of responsibility (Section II). To formalize this commitment, each involved agency has included their director's signature on the signature page, located near the back of the Plan.

The Plan provides specific timelines and objectives. Funding for a statewide coordinator has been acquired (Section VIII) to help organize local working groups and be responsible for facilitating and coordinating local planning and implementation efforts. The Plan includes a "road map" as to where and when working groups will be organized and what their basic role will be. Nationally, Montana's strength in sage grouse conservation is the productive intact habitats it supports. Maintaining and enhancing the habitat base is the highest priority. FWP's commitment includes an objective to acquire sagebrush-grassland protection on 183,000 acres of privately-owned habitat within the coming 3 years. Contingent on landowner interest, additional funding will be pursued to continue purchasing habitat protection. Federal and state land management agencies have also expressed their individual commitments to conserve sage grouse habitat and, where possible, work with partnerships to improve habitat productivity, using conservation strategies identified in this Plan. NRCS has designated sage grouse in Montana a priority species which helps direct conservation funding toward projects that will benefit sage grouse on private lands.

FWP will annually compile information on accomplishments and, with the state coordinator and the Montana Sage Grouse Working Group, will assess and evaluate local working group efforts (Section VIII). As conditions change and our knowledge base continues to grow, this active process will allow for adapting and adjusting management strategies (Section VIII).

Sage grouse will also be evaluated based on Section 4(a)(1) of the Endangered Species Act, that requires the Fish and Wildlife Service to assess the real or potential risks to a petitioned species based on five factors. This section summarizes how the Montana Sage Grouse Conservation Plan 
provides strategies or conservation actions to address the five factors and reduces potential threats to the viability of sage grouse in Montana.

\section{Factor 1: Habitat}

"present or threatened destruction, modification, or curtailment of its habitat or range"

Although determining the exact degree of destruction, modification, or curtailment of sage grouse habitat is difficult, some estimate that populations in Montana have declined by about 30 percent. Losses are attributed to conversion of native range to cropland, nonnative seedings, shrub loss by manipulation or wildfire, and permanent human developments since the late 1800s.

The conservation plan addresses additional habitat loss in several ways. The broad scale habitat objective states that we will maintain the distribution of sagebrush across its current range. Acknowledging that short-term losses, i.e., $<50$ years, may occur in localized areas, losses should be offset by restoration and other management actions to result in a no net loss in overall distribution and quality of sagebrush habitat.

Conservation actions described under fire management, livestock grazing management, mining and energy development, management of noxious weeds, power lines and generation facilities, vegetation management, and wildlife management include actions and solutions to issues that may cause a reduction in the loss of functional sagebrush habitat. Actions described in the education and outreach section should supply products and information to encourage agency and private landowners to manage for healthy sagebrush communities.

In May 1997, regional standards for rangeland health and guidelines for livestock grazing were approved for BLM lands in Montana and the Dakotas in conformance with 43 CFR 4180.1, Fundamentals of Rangeland Health (ROD Standards for Rangeland Health and Guidelines for Livestock Grazing Management for Montana, North Dakota and South Dakota, May 1997). Before an activity can occur on BLM-managed lands, the agency must address how the action will or will not contribute to meeting standards for functioning watersheds, healthy biotic populations and communities, clean water and air, and special status species. This regulation is consistent with actions to reduce threats posed by ESA Factor 1.

Montana Fish, Wildlife and Parks (FWP) has the authority to enter into conservation easements or land purchases to protect and enhance wildlife habitats. Covenants are attached to these properties to conserve and enhance native range and wildlife and prohibit manipulation of sagebrush habitat, subdivision, or conversion of rangeland to cropland. This priority will continue under this plan. FWP has initiated a new private land sagebrush protection program that is funded through the Landowner Incentive and Upland Game Bird Programs. With the initial funding of \$2.6 million, they anticipate protecting 183,000 acres of sage grouse-occupied private lands from herbicide spraying, prescribed burning, and conversion to cropland. In addition, over 550,000 acres of private land are under grazing management contracts through FWP habitat programs. . Fifty percent of the funds from the Upland Game Bird Habitat Enhancement program will continue to support habitat projects to enhance sagebrush habitat under the Montana Sage Grouse Conservation Plan. 


\section{Factor 2: Over-Utilization}

“over-utilization for commercial, recreational, scientific, or educational purposes"

Hunting, lek viewing, and scientific studies have the potential to pose threats if left unregulated. Each of these items is addressed by either conservation actions in the plan or agency regulation.

Currently, populations of sage grouse in Montana appear stable, and hunting regulations are liberal compared to other states. Based on analyses of lek counts and harvest surveys, we believe that the portion of the population taken by hunters is $<10$ percent. FWP is responsible for making recommendations to the Fish, Wildlife and Parks Commission, which hold statutory authority to set season length and bag limits. Through the conservation plan, FWP makes a commitment to an adaptive harvest management strategy that will allow season recommendations to be based on current lek survey information using pre-determined thresholds to adjust seasons or bag limits. FWP also regulates permits for sage grouse trapping for scientific studies. The agency has the authority to refuse an applicant if the studies or actions pose a threat to the continued existence of an isolated, depressed population.

Lek viewing has become more popular as the public learns about sage grouse behavior and declines in population. Conservation actions under "Recreational Disturbance" include recommendations to manage lek viewing in order to reduce or minimize disturbance to birds. In addition, the work group recommends limiting information about lek locations to the public to protect birds during breeding times and fall hunting seasons when birds gather near leks.

\section{Factor 3: Disease or Predation}

\section{"disease or predation"}

West Nile virus was detected for the first time in sage grouse in Montana, Wyoming and Alberta during late summer 2003. Mosquitoes (especially Culex tarsalis) are thought to be the principal vectors of the disease and migratory birds appear to be the major introductory host. The presence of a large sample of radio-instrumented sage grouse on several research study sites provided an opportunity to both detect mortalities and collect carcasses for submission to diagnostic labs. Preliminary evidence suggests variable rates of mortality among the study sites with 19 confirmed mortalities in Wyoming, 3 in Montana, and 5 in southeastern Alberta (B.Walker, 2003, pers. communication). Other confirmed mortalities were inconclusive from a diagnostic standpoint due to the decomposed condition of the carcass at the time of collection. Additional lab results and final analysis of the 2003 outbreak are pending. Future monitoring will be necessary to document the impact on population trends and the role of the virus in terms of observed mortality rates in subsequent years.

The composition and abundance of various avian and mammalian predator species has changed and continues to change since the termination of widespread predator control activities in the early 1970s. The long-term biological consequences of predator control or no control of predators are poorly understood. Most think that some combination of sagebrush habitat quantity 
and quality, composition of the predator communities, and weather patterns such as drought or severe winters plays an integrated role in long-term population trends.

The conservation plan addresses predation from various angles. Because the effects of predation by different predator species need further investigation, the plan recommends actions to initiate cooperative studies. In areas where habitat fragmentation may contribute to sage grouse mortality by predators, management actions will be taken to restore and enhance habitat. Additional actions include:

- reducing or minimizing man-made alterations that may facilitate increased predation

- implementing some form of predator control at specific sites or situations when an isolated population is at risk.

\section{Factor 4: Existing Regulation}

"inadequacy of existing regulatory mechanisms"

Regional standards for rangeland health and guidelines for livestock grazing were approved for BLM lands in Montana and the Dakotas in conformance with 43 CFR 4180.1, Fundamentals of Rangeland Health (ROD Standards for Rangeland Health and Guidelines for Livestock Grazing management for Montana, North Dakota and South Dakota, May 1997). The standards provide a basis for maintaining habitats for special status species. Habitat objectives from the sage grouse conservation plan and relevant information describing the desired condition for sage grouse seasonal habitats will be considered when establishing the desired resource condition for BLM managed lands.

The BLM Land Use Planning Handbook (H 1601-1) provides guidance for addressing special status species during programmatic planning. Direction given in the handbook states that BLM will incorporate conservation for species at a level of specificity sufficiently detailed to enhance habitat or prevent avoidable loss. As individual Field Office Resource Management Plans are amended through the NEPA process, all sources of information (including the conservation plan and available sagebrush management technical references) will be used to determine the best option to conserve sage grouse and their habitats in the planning area.

Through other various levels of BLM planning, e.g., project, allotment, watershed, conservation measures for sage grouse may be integrated through the NEPA process. Even though BLM has participated in the conservation planning process and remains committed to the conservation of special status species, there is no guarantee that each action identified in the conservation plan will be implemented on every acre. Multiple use mandates often influence short-term habitat losses to meet competing demands on federal lands. Full public participation and disclosure through the NEPA process are required with every decision.

FWP is adopting the conservation plan population objectives and the adaptive hunting management strategy by reaching a decision through the MEPA process. The decision document will give the agency the authority to take actions and spend program dollars that will contribute to meeting population objectives. 


\section{Factor 5. Other Factors}

"other natural or manmade factors affecting its continued existence"

No widespread control programs are known to be a risk to sage grouse. Recent genetic testing of genetic variation by Oyler-McCance et al (2001) suggests sage grouse populations in Montana exhibit high genetic diversity. Factor 5 has not been considered a risk in Montana and has not been addressed in the conservation plan. 


\section{LITERATURE CITED}

Aldrich, J. W. 1963. Geographic orientation of American tetraonidae. Journal of Wildlife Management 27: 529-545.

Aldridge, C. L. 1998. Status of the sage grouse (Centrocercus urophasianus urophasianus) in Alberta. Alberta Environmental Protection, Wildlife Management Division, and Alberta Conservation Association, Wildlife Status Report No. 13, Edmonton. 23 pp.

Anderson, S. H., and K. J. Gutzwiller. 1994. Habitat evaluation methods. Pages 592-606 in T. A. Bookhout, editor. Research and management techniques for wildlife and habitats. The Wildlife Society, Bethesda, Maryland.

Angelstram, P.1986. Population dynamics in tetraonids: the role of extrinsic factors. Proceedings of the International Ornithological Congress. 19:2458-2477.

Apa, A. D. 1998. Habitat use and movements of sympatric sage and Columbian sharp-tailed grouse in southeastern Idaho. Dissertation, University of Idaho, Moscow.

, K. P. Reese, and J.W. Connelly, Jr. 1997. An evaluation of nest placement theory using artificial and Columbian sharp-tailed grouse Tympanuchus phasianellus columbianus nests. Wildlife Biology 3:278.

Autenrieth, R. E. 1981.Sage Grouse management in Idaho. Idaho Department of Fish and Game, Wildlife Bulletin 9, Boise.

Avian Power Line Interaction Committee (APLIC). 1994. Mitigating bird collisions with power lines: the state of the art in 1994. Edison Electric Institute, Washington, DC. 78 pp.

Ball, I. J., R. L. Eng, and S. K. Ball. 1995. Population density and productivity of ducks on large grassland tracts in North Central Montana. Wildlife Society Bulletin 23:767-773.

Barnett, J. K., and J. A. Crawford. 1994. Pre-laying nutrition of sage grouse hens in Oregon. Journal of Range Management 47:114-118.

Bean, R. 1941. Life history studies of the Sage Grouse (Centrocercus urophasianus) in Clark County, Idaho. Thesis. Utah Agricultural College, Logan.

Beck, T. D. I. 1975. Attributes of a wintering population of sage grouse, North Park, Colorado. Colorado State University, Fort Collins. 49 pp.

Beck, J. L., and D. L. Mitchell. 2000. Influences of livestock grazing on sage grouse habitat. Wildlife Society Bulletin 28:993-1002.

Beetle, A. A., and K. L. Johnson. 1982. Sagebrush in Wyoming. Bulletin 779, Agricultural Experiment Station, University of Wyoming. 68 pp. 
Borell, A. E. 1939. Telephone wires fatal to sage grouse. Condor 41:85-86.

Braun, C. E. 1987. Current issues in sage grouse management. Proceedings of the Western Association of Fish and Wildlife Agencies 67:134-144. . 1998. Sage grouse declines in western North America: What are the problems? Proceedings of the Western Association of State Fish and Wildlife Agencies. , M. F. Baker, R. L. Eng, J. W. Gashwiler, and M. H. Schroeder. 1976. Conservation committee report on effects of alteration of sagebrush communities on the associated avifauna. Wilson Bulletin 88:165-171.

, T. Britt, and R. O. Wallestad. 1977. Guidelines for maintenance of sage grouse habitats. Wildlife Society Bulletin 5: 99-106.

Bump, G., R. W. Darrow, F. C. Edminster, and W. F. Crissey. 1947. The ruffed grouse: life history, propagation, and management. New York State Conservation Department, Holling, Buffalo.

Call, M. W. and C. Maser. 1985. Wildlife habitats in managed rangelands - the great basin of southeastern Oregon. Sage grouse. United States Department of Agriculture, Forest Service, General Technical Report PNW-187, Portland, Oregon, USA.

Canfield, R. H. 1941. Application of the line interception method in sampling range vegetation. Journal of Forestry 39:388-394.

Connelly, J. W. 1982. An ecological study of sage grouse in southeastern Idaho. Dissertation, Washington State University, Pullman, USA.

, J. W., W. J. Arthur, and O. D. Markham. 1981. Sage grouse leks on recently disturbed sites. Journal of Range Management 52:153-154.

, J. W., and C. E. Braun. 1997. Long-term changes in sage grouse Centrocercus urophasianus populations in western North America. Wildlife Biology 3:229-234.

, H. W. Browers, and R. J. Gates. 1988. Seasonal movements of sage grouse in southeastern Idaho. Journal of Wildlife Management 52:116-122.

, and L. A. Doughty. 1990. Sage grouse use of wildlife water developments in southeastern Idaho. Pp. 167-172 in G. K. Tsukamoto and S. J. Striver, eds., Wildlife, Water Development: A Proceedings of the Wildlife Water Development Symposium, Las Vegas, NV, Nov. 29-Dec. 1, 1988.

, J.W., R.A. Fischer, A.D. Apa, K.P. Reese, and W.L. Wakkinen. 1993. Renesting by sage grouse in southeastern Idaho. Condor 95: 1041-1043.

, K. P. Reese, Richard A. Fischer, and W. L. Wakkinen. 2000a. Response of a sage

grouse breeding population to fire in southeastern Idaho. Wildlife Society Bulletin 28:90-96. 
, M. A. Schroeder, A. R. Sands, and C. E. Braun. 2000b. Guidelines to manage Sage Grouse populations and their habitats. Wildlife Society Bulletin 28:967-985.

, W. L. Wakkinen, A. D. Apa, and K. P. Reese. 1991. Sage grouse use of nest sites in southeastern Idaho. Journal of Wildlife Management 55:521-524.

Dalke, P. D., D. B. Pyrah, D. C. Stanton, J. E. Crawford, and E. F. Schlatterer. 1963. Ecology, productivity, and management of sage grouse in Idaho. Journal of Wildlife Management 27: 810-841.

Daubenmire, R. 1970. Steppe vegetation of Washington. Washington Agricultural Experiment Station. Technical Bulletin 62.131 pp.

DeLong, A. K., J. A. Crawford, and D. C. DeLong. 1995. Relationships between vegetational structure and predation of artificial sage grouse nests. Journal of Wildlife Management 59:88-92.

Dobler, F. C. 1994. Washington state shrub-steppe ecosystem studies with emphasis on the relationship between nongame birds and shrub and grass cover densities. Pp. 149-161 in S. B. Monson and S. G. Kitchen, comps., Proceedings of a symposium on ecology and management of intermountain annual rangelands. 1992. Boise, ID. General Technical Report, INT-GTR-313, USDA Forest Service, Intermountain Research Station, Ogden, UT.

Drut, M. S., W. H. Pyle, and J. A. Crawford. 1994. Brood habitat by sage grouse in Oregon. Great Basin Naturalist 54:170-176.

Edwards, W. R. 1988. Realities of population regulation and harvest management. Pp. 307-335 in D. L. Hallet, W. R. Edwards, G. V. Burger, eds. Pheasants: symptoms of wildlife problems on agricultural lands. Proceedings of the $49^{\text {th }}$ Midwest Fish and Wildlife Conference, Milwaukee, WI, North-central Section, The Wildlife Society.

Egan, J. 2000. Managing the range with livestock. Helena, MT. 12 pp.

Eng, R. L. 1955. A method for obtaining sage grouse age and sex ratios from wings. Journal of Wildlife Management 19:267-272. , and P. Schladweiler. 1972. Sage grouse winter movements and habitat use in central Montana. Journal of Wildlife Management 36:141-146.

Eustace, C. D. 2002. Sage grouse hatching success and chronology for south-central Montana. Intermountain Journal of Sciences 8:82-93.

Fischer, R. A. 1994. The effects of prescribed fire on the ecology of migratory sage grouse in southeastern Idaho. Dissertation, University of Idaho, Moscow. , A. D. Apa, W. L. Wakkinen, K. P. Reese, and J. W. Connelly. 1993. Nesting-area fidelity of sage grouse in southeastern Idaho. Condor 95:1038-1041. 
, K. P. Reese, and J. W. Connelly. 1996. An investigation on fire effects within xeric sage grouse brood habitat. Journal of Range Management 49:194-198.

, W. L. Wakkinen, K. P. Reese, and J. W. Connelly. 1997. Effects of prescribed fire on movements of female sage grouse from breeding to summer ranges. Wilson Bulletin 109: 82-91.

Gill, R. B. 1965. Distribution and abundance of a population of sage grouse in North Park, Colorado. Colorado State University, Fort Collins. 185 pp.

Greenwood, R.J., A.B. Sargeant, D.H. Johnson, and L. Cowardin. 1995. Factors associated with duck nest success in the prairie pothole region of Canada. Wildlife Monograph 128:1-57.

Gregg, M. A. 1991. Use and selection of nesting habitat by sage grouse in Oregon. Thesis, Oregon State University, Corvallis.

, J. A. Crawford, M. S. Drut, and A. K. DeLong. 1994. Vegetational cover and predation of sage grouse nests in Oregon. Journal of Wildlife Management 58:162-166.

Gunderson, P. 2001. Sage grouse status and harvest opportunities in northeastern Montana. Annual meeting of the Montana Chapter, The Wildlife Society, Butte. Abstract only.

Gutzwiller, K. J. 1991. Assessing recreational impacts on wildlife: the value and design of experiments. Transactions of the North American Wildlife and Natural Resources Conference 56:248-255.

Hansen, P. L. and R. D. Pfister, K. Boggs, B. J. Cook, J. Joy, and D. K. Hinckley. 1995. Classification and management of Montana's riparian and wetland sites. Montana Forest and Conservation Experiment Station. Miscellaneous Publication No. 54. 646 pp. School of Forestry, The University of Montana, Missoula, Montana

Harrington, R. D. 2002. A historical perspective of Montana's sagebrush. Intermountain Journal of Sciences 8(2):60-66.

Heath, B. J., R. Straw, S. H. Anderson, J. Lawson, and M. Holloran. 1998. Sage grouse productivity, survival, and seasonal habitat use among three ranches with different livestock grazing, predator control, and harvest management practices.

, R. Straw, S. H. Anderson, and J. Lawson. 1977. Sage grouse productivity, survival, and seasonal habitat use near Farson, Wyoming. Wyoming Game and Fish Department, Project Completion Report, Laramie.

Holloran, M. J. 1999. Sage grouse (Centrocercus urophasianus) seasonal habitat use near Casper, Wyoming. Thesis, University of Wyoming, Laramie.

Homer, C. G., T. C. Edwards, Jr., D. H. Ramsey, and K. H. Price. (1993), Use of remote sensing methods in modeling sage grouse winter habitat, J. Wild. Manage. 57:78-84 
Hormay, A. C. 1970. Principles of rest-rotation grazing and multiple-use land management. Training text-4. USDA Forest Service. 25 pp.

Hupp, J. W., and C. E. Braun. 1989. Topographic distribution of sage grouse foraging in winter. Journal of Wildlife Management 53:823-829.

Johnson, G. D., and M. S. Boyce. 1990. Feeding trials with insects in the diet of sage grouse chicks. Journal of Wildlife Management 54:89-91.

Jones, R. E., and K. E. Hungerford. 1972. Evaluation of nesting cover as protection from magpie predation. Journal of Wildlife Management 36:727-732.

Jorgensen, H. E. 1979. Vegetation of the Yellow Water Triangle, Montana. Technical Bulletin. Montana Department of Fish and Game, Helena, and USDI Bureau of Land Management. $57 \mathrm{pp}$.

Joslin, G., and H. Youmans, comps. 1999. Effects of recreation on Rocky Mountain wildlife: a review for Montana. Committee on Effects of Recreation on Wildlife, Montana Chapter of the Wildlife Society. 307 pp.

Keister, G. P., and M. J. Willis. 1986. Habitat selection and success of sage grouse hens while nesting and brooding. Oregon Department of Fish and Wildlife, Progress Report W-87R-2, Subproject 285, Portland.

Klebenow, D. A. 1969. Sage grouse nesting and brood habitat in Idaho. Journal of Wildlife Management 33: 649-662. , and G. M. Gray. 1968. Food habits of juvenile sage grouse. Journal of Range Management 21: 80-83.

Klott, J. H., R. B. Smith, andC. Vullo. 1993. Sage grouse habitat use in the Brown's Bench area of south-central Idaho. USDI Bureau of Land Management, Idaho State Office, Technical Bulletin 93-4, Boise.

Knick, S. T. 1999. Requiem for a sagebrush ecosystem? Northwest Science 73:53-57.

Leonard, K. M., K. P. Reese, and J. W. Connelly. 2000. Distribution, movements, and habitats of sage grouse Centrocercus urophasianus on the Upper Snake River Plain of Idaho: changes from the 1950's to the 1990's. Wildlife Biology 6:265-270.

Lyon, A.G. 2000. The potential effects of natural gas development on sage grouse (Centrocercus urophasianus) near Pinedale, Wyoming. Thesis, University of Wyoming, Laramie.

Martin, 1970. Sagebrush control related to habitat and sage grouse occurrence. Journal of Wildlife Management 34: 313-320. , N., and D. Pyrah. 1971. Sage Grouse. Pp. 135-141 in T. W. Mussehl and F. W. Howell, 
eds. Game Management in Montana. Helena, MT: Mont. Dept. Fish \& Game.

Mattise, S. N. 1995. Sage Grouse in Idaho: Forum '94. Idaho Bureau of Land Management Technical Bulletin No. 95-15.

Messmer, T. A., M. W. Brunson, D. Reiter, and D. G. Hewitt. 1999. United States public attitudes regarding predators and their management to enhance avian recruitment. Wildlife Society Bulletin 27:75-85.

Montana Department of Natural Resources and Conservation (DNRC). 1999. Best management practices for grazing. Helena.

Montana Fish, Wildlife and Parks. 1991. Upland game bird harvest management in Montana. A report to the Fish and Game Commission, February.

1994. Draft environmental assessment and noxious weed plan. Region 3, Bozeman. 69 pp.

Moynahan, B. J., J. W. Thomas, and M. Lindberg. 2001. Understanding relationships between sage grouse habitat and population dynamics in eastern Montana. Annual meeting of the Montana Chapter, The Wildlife Society, Butte. Abstract only.

Mueggler, W. F. and W. L. Stewart. 1978. Grassland and shrubland habitat types of Western Montana. USDA Forest Service. General Technical Report INT-66. 154 pp. Intermountain Forest and Range Experiment Station, Ogden, Utah 84401.

Myrberget, S. 1988. Demography of an island population of willow ptarmigan in northern Norway. Pp. 379-418 in A. T. Bergerud and M. W. Gratson, eds., Adaptive strategies and population ecology of northern grouse. University of Minnesota, Minneapolis.

Nelson, H. K. 2001. Impact to predation on avian recruitment - An Introduction. Wildlife Society Bulletin 29:2-5.

Oakleaf, R. J. 1971. The relationship of sage grouse to upland meadows in Nevada. Nevada Fish and Game Commission, Job Progress Report W-48-2. 64 pp.

Oyler-McCance, S. J., S. E. Taylor, and T. W. Quinn. 2001. Genetic characterization of sage grouse populations throughout their range. The Wildlife Society, National Conference, Reno/Tahoe, NV. Abstract only.

Patterson, R. L. 1952. The sage grouse in Wyoming. Wyoming Game and Fish Commission, and Sage Books, Inc., Denver, CO. 341 pp.

Peterson, B. E. 1980. Breeding and nesting ecology of female sage grouse in North Park, Colorado. Thesis, Colorado State University, Fort Collins. 
Peterson, J. G. 1970a. The food habits and summer distribution of juvenile sage grouse in central Montana. Journal of Wildlife Management 34:147-155.

1970b. Gone with the sage. Montana Outdoors 5(9):1-3.

1995. Ecological implications of sagebrush manipulation: a literature review. Montana Fish, Wildlife, and Parks, Helena, MT. 49 pp.

Peterson, M. J., and N. J. Silvy. 1996. Spring precipitation and fluctuations in Attwater's prairie chicken numbers: hypotheses revisited. Journal of Wildlife Management 58: 222-229.

Potts, G. R. 1986. The partridge: pesticides, predation, and conservation. Collins Professional and Technical Books, London, UK. 274 pp.

Pyrah, D. B. 1972. Effects of chemical and mechanical sagebrush control on sage grouse. Montana Fish and Game Department, Job Completion Report W-105-R-6, Helena, MT.

Rice L. A. and A. V. Carter. 1982. Evaluation of South Dakota Management Practices as they affect prairie chicken populations, 1974-78. Pittman-Robertson Project W-75-R(16-21), Study PC-7.1(7509). 25 pp.

Roscoe, J. W. 2002. Sage grouse movements in southwestern Montana. Intermountain Journal of Sciences In press.

Reynolds, R. E., T. L. Shaffer, R.W. Renner, W.E. Newton, and B.D.J. Batt. 2001. Impact of the Conservation Reserve Program on duck recruitment in the U.S. Prairie Pothole Region. Journal of Wildlife Management 65(4):765-780.

Robertson, M. D. 1991. Winter ecology of migratory sage grouse and associated effects of prescribed fire in southeastern Idaho. Thesis, University of Idaho, Moscow.

Roedel, M. D. 1999. Montana animal species of special concern. [Unpublished List] Montana Natural Heritage Program, Helena. 8 pp.

Rogers, G. E. 1964. Sage grouse investigations in Colorado. Colorado Game, Fish and Parks Department, Technical Publication 16. 132 pp.

Roscoe, J. W. 2002. Sage grouse movements in southwest Montana. Intermountain Journal of Sciences 8(2):94-104.

Savage, D. E. 1968. Relation of sage grouse to upland meadows in Nevada. Nevada Fish and Game Commission, Job Completion Report, Project W-39-R-9, Job 12, Reno.

Schlatterer, E. F. 1960. Productivity and movements of a population of sage grouse in southeastern Idaho. M.S. thesis, University of Idaho, Moscow. 87 pp. 
Schroeder, M. A. 1995. Productivity and habitat use of sage grouse in north-central Washington. Washington Department of Fish and Wildlife, Job Progress Report, Project W-96-R, Olympia.

, and R. K. Baydack. 2001. Predation and the management of prairie grouse. Wildlife Society Bulletin 29:34-32.

, D. W. Hays, M. F. Livingston, L. E. Stream, J. E. Jacobson, and D. J. Pierce. 2000. Changes in the distribution and abundance of sage grouse in Washington. Northwestern Naturalist 81:104-112.

Scott, J. W. 1942. Mating behavior of the Sage Grouse. Auk 59:477-498.

Sibley, D. A. 2000. National Audubon Society - the Sibley guide to birds. Chanticleer Press, Inc., New York. 545 pp.

Simon, F. 1940. The parasites of the sage grouse (Centocercus urophasianus). University of Wyoming Publ. 7(5):77-100.

Svedarsky, Daniel and Gerald Van Amburg. 1996. Integrated management of the greater prairie chicken and livestock on the Sheynne National Grassland. North Dakota Game and Fish Department, Bismark, ND. Jamestown, ND: Northern Prairie Wildlife Research Center Home Page. http://www.npwrc.usgs.gov/resource/othrdata/sheyenne/sheyenne.htm (version 16JUL97).

Sveum, C. M., J. A. Crawford, and D. Edge. 1998. Use and selection of brood-rearing habitat by sage grouse in south central Washington. Great Basin Naturalist 58: 344-351.

Swenson, J. E., C. A., Simmons, and C. D. Eustace. 1987. Decrease of sage grouse Centrocercus urophasianus after ploughing of sagebrush steppe. Biological Conservation 41: 125-132.

Trombulak, S. C., and C. A. Frissell. 2000. Review of ecological effects of roads on terrestrial and aquatic communities. Conservation Biology 14:18-30.

Tueller, P. T. 1989. Remote sensing technology for rangeland management applications, Journal of Range Management, 42(6), 442-453.

Wakkinen, W. L. 1990. Nest site characteristics and spring-summer movements of migratory sage grouse in southeastern Idaho. Thesis, University of Idaho, Moscow.

, K. P. Reese, and J. W. Connelly. 1992. Sage grouse nest locations in relation to leks. Journal of Wildlife Management 56: 381-383.

Wallestad, R. O. 1971. Summer movements and habitat use by sage grouse broods in central Montana. Journal of Wildlife Management 35: 129-136. 
. 1975. Life History and habitat requirements of sage grouse in central Montana. Technical Bulletin. Montana Department of Fish and Game, Helena, and USDI Bureau of Land Management. $65 \mathrm{pp}$. , and C. R. Watts. 1973. Factors affecting annual sage grouse productivity in central Montana. Fed. Aid Proj. W-120-R-3, Montana Department of Fish and Game, Helena. 23 pp.

, and D. Pyrah. 1974. Movement and nesting of sage grouse hens in central Montana. Journal of Wildlife Management 38: 630-633. , and P. Schladweiler. 1974. Breeding season movements and habitat selection of male sage grouse. Journal of Wildlife Management 38: 634-637.

Wambolt, C. L., and M.R. Frisina. 2002. Montana sagebrush: A taxonomic key and habitat descriptions. Intermountain Journal of Sciences 8(2): 46-59.

, A. J. Harp, B. L. Welch, N. Shaw, J. W. Connelly, K. P. Reese, C. E. Braun, D. A. Klebenow, E. D. McArthur, J. G. Tohmpson, L. A. Torell, and J. A. Tanaka. 2002. Conservation of greater sage grouse on public lands in the western U. S.: Implications of recovery and management policies. Policy Analysis Center for Western Public Lands Policy Paper SG-02-02. 41pp.

Watters, M. E. and T. L. McLash, C. L. Aldridge, and R. M. Brigham. 2002. The effect of vegetation structure on predation of artificial greater sage-grouse nests. Ecoscience 9:314-319.

Welch, B. In Preparation. Big sagebrush:A sea fragmented into lakes, puddles, and ponds. On file at the United States Forest Services Shrub Sciences Lab., 735 N 500 E, Provo, Utah 84606 


\section{GLOSSARY AND ACRONYMS}

Abundance: The number of individuals in a population of a species in a given unit of area.

Adaptive Harvest Management: An approach used to establish hunting seasons that relies on monitoring certain population parameters, e.g. number of leks, numbers of males/lek, a set of regulation packages (e.g., restrictive versus liberal bag limits yielding different rates of harvest), and specific population thresholds that trigger a regulation change. This approach employs a direct feedback loop where population status or trend may be used to select the most appropriate harvest strategy.

Additive mortality hypothesis: As hunting kill rate (probability that an animal is killed by a hunter during a year) increases, annual survival rate decreases in an approximately linear manner. If we make the simplifying assumption that no non-hunting mortality occurs during the hunting season, then $\mathrm{S}_{i}=\mathrm{S}_{0} \mathrm{x}\left(1-\mathrm{K}_{i}\right)$ where $\mathrm{S}_{i}$ is the annual survival rate in year $1, \mathrm{~S}_{0}$ is the annual survival rate in the absence of hunting mortality, and $\mathrm{K}_{i}$ is the probability that an animal is killed by a hunter during year 1. (see Compensatory mortality hypothesis).

Adverse impact/effect: Damage or harm caused by an action.

Agricultural resources: Crops and livestock.

Allotment: An area designated for the use of a prescribed number and kind of livestock under one plan of management. (SRM)

Animal Unit: Considered to be one mature cow (1000 lb), either dry or with calf up to 6 months of age, or the equivalent based on average daily forage consumption of $26 \mathrm{lb}$ dry matter/day. Abbr. AU (SRM)

Animal-Unit-Month: The amount of oven-dry forage (forage demand) required by one animal unit for a standardized period of 30 animal-unit-days. Not synonymous with animal month. Abbr. AUM. The term AUM is commonly used in three ways: (a) stocking rate, as in "X acres per AUM"; (b) forage allocations, as in "X AUMs in Allotment A"; (c) utilization, as in "X AUMs taken from Unit B." (SRM)

Aquifer: A geologic formation capable of transmitting water through its pores at a rate sufficient for water supply purposes that is usually composed of saturated sands, gravel, fractures, caverns, or vesicular rock. (SRM)

Backfire: A fire set along the inner edge of a fireline to consume the fuel in the path of a wildfire and/or change the direction of force of the fire's convection column. (NIFC)

Beneficial impact/effect: An improvement, e.g., improved wellbeing of an organism/population or its habitat, caused by a management action. 
Biodiversity or biological diversity: The variety of life and its processes. It includes the variety of living organisms, the genetic differences among them, and the communities and ecosystems in which they occur.

Biological impact: Any impact to animal abundance or species diversity.

Biomass: The total of living plants and animals above and below ground in an area at a given time. $(S R M)$

Broadcast seeding: Scattering seed on the surface of the soil. (SRM)

Canopy: (1) The vertical projection downward of the aerial portion of vegetation, usually expressed as a percentage of ground so occupied, or (2) the aerial portion of the overstory vegetation. $(S R M)$

Carrying capacity: The average number of livestock and/or wildlife that may be sustained on a management unit compatible with management objectives for the unit. In addition to site characteristics, it is a function of management goals and management intensity. (SRM)

Chiseling: Breaking or loosening the soil with a chisel plow (without inversion), used most often in grasslands with rhizomatous (plant) species. (SRM)

Class of Animal: Description of age and/or sex-group for a particular kind of animal. Example, cow, calf, yearling, ewe, doe, fawn, etc. (SRM)

Climax: The final or stable biotic community in a successional series; it is self-perpetuating and in equilibrium with the physical habitat. $(S R M)$

Competition: The general struggle for existence within a trophic level in which living organisms compete for a limited supply of the necessities of life. (SRM)

Community: An integrated group of species inhabiting a given area; the organisms within a community influence one another's distribution, abundance, and evolution.

Compensatory mortality hypothesis: Annual survival rate is independent of variation in kill rate whenever kill rate is less than some threshold value (c). However, after hunting mortality rate reaches the threshold value, further increases in kill rate do bring about decreases in annual survival rate. $\mathrm{S}_{i}=\mathrm{S}_{0}$ for $0<\mathrm{K}_{i}<\mathrm{c}$ (see Additive mortality hypothesis).

Conservation: The protection, maintenance, management, sustainable use, restoration, and enhancement of the natural environment.

Conservation easement: A legal agreement to ensure permanent preservation of land in its natural state or whatever degree of naturalness the land possesses at the time the easement is granted. 
Contact herbicide: A herbicide that kills primarily by contact with plant tissue rather than as a result of translocation. (SRM)

Continuous grazing: Grazing of a specific unit by livestock throughout a year or for that part of the year during which grazing is feasible. $(S R M)$

Cooperative agreement: A written agreement between agencies, institutions, or individuals that specifies mutual intent to work together for specific purposes, such as fire suppression, and may detail the role of each party to the agreement

Cooperator: An individual or agency working under agreement with a public agency. These entities may contribute funds, facilities, and personnel to achieve wildlife management objectives or may be enrolled in one or more publicly funded programs.

Critical habitat: The essential segments of habitat that contain the unique combination of conditions, i.e., vegetation, topography, soil, species niches, etc., necessary for the continued survival of an endangered or threatened species, as listed in 50 CFR 17 or 226.

Cumulative impacts: The additive effect of environmental impacts from various government actions in the past, present, and foreseeable future. Cumulative impacts can result from accumulation of individually minor but collectively significant actions occurring over time.

Deferment: The delay of grazing to achieve a specific management objective. A strategy aimed at providing time for plant reproduction, establishment of new plants, restoration of plant vigor, a return to environmental conditions appropriate for grazing, or the accumulation of forage for later use. (SRM)

Deferred grazing: The deferment of grazing in a nonsystematic rotation with other land units. $(S R M)$

Deferred rotation: Any grazing system, which provides for a systematic rotation of the deferment among pastures. (SRM)

Distribution lines: Power lines (1-69 KV) used to serve individual residential, business, and agricultural customers.(APLIC)

Drift fence: An open-ended fence used to retard or alter the natural movement of livestock; generally used in connection with natural barriers. (SRM)

Drill seeding: Planting seeds directly into the soil with a drill in rows, usually 6-24 inches apart. $(S R M))$

Ecological community: Any assemblage of populations living in a specific habitat. 
Ecosystem: A complete, interacting system of organisms considered together with their environment, such as a sagebrush steppe, marsh, watershed, or lake.

Ecosystem management: A concept of natural resource management wherein agency activities are considered within the context of economic, ecological, and social interaction within a defined area or region over both the short and long term.

Endangered species: A plant or animal species listed in the Federal Register as an "endangered species" whose prospects of continued survival, and reproduction are in immediate jeopardy. Its peril may result from habitat loss or change, over-exploitation, predation, competition, disease, or unknown causes.

Endangered Species Act (ESA): Federal or state statutes under which species may be designated threatened or endangered.

Environment: The surrounding conditions, influences, or forces that affect or modify an organism or an ecological community and ultimately determine its form and survival.

Exotic species: Species not native or indigenous to an area, e.g., Norway rat, starling, rock dove, and house sparrow in North America, that occur by deliberate or accidental human actions (see Introduced species).

Extirpation: A term used to describe the reduction of some wildlife species to near extinction, particularly during the time of European settlement of western North America.

Flexibility: Ability to alter a grazing management plan to meet changing conditions. (SRM)

Foliage: The green or live leaves of plants. (SRM)

Forb: Any broad-leafed herbaceous plant other that of the families Gramineae, Cyperaceae, and Juncaceae. (SRM)

Full use: The maximum use during a grazing season that can be made of range forage under a given grazing program without inducing a downward trend in range condition or successional status. (SRM)

Functional Sagebrush Community: A contiguous block of habitat that supports sagebrush and a diverse mix of native grasses and forbs, capable of sustaining sagebrush-associated wildlife.

Habitat: An environment with the requirements, such as food, water, and shelter that are essential to development and sustained existence of a species.

Habitat fragmentation: 1) Patches of habitat separated from larger patches of habitat that could reduce the capacity to produce wildlife; 2) the separation of an organism's environment 
in such a manner as to inhibit species movement and/or facilitate distribution of disruptive elements, e.g., predators, noxious weeds, etc.

Habitat management: Human actions that protect or modify a habitat to maintain, increase, or decrease its ability to produce, support, or attract wildlife.

Habitat security: The protection that the structural component of habitat, such as topography or vegetative cover, provides to reduce an animal's vulnerability to disturbance.

Harvest data: An estimate of the number of animals removed from a population by hunting or trapping.

Harvest rate: An estimate of the proportion of a game or furbearer population that is harvested during a given year or hunting/trapping season.

Heavy grazing: A comparative term that indicates that the stocking rate of a pasture is relatively greater than that of other pastures. Often erroneously used to mean overuse. (SRM)

Hunter days: A unit of measure used to report hunter effort as it relates to harvest surveys, or a quantitative expression of recreational opportunity, whereby a hunter day represents one hunter afield for one day or a part of one day.

Increaser: For a given plant community, those species that increase in amount as a result of a specific abiotic/biotic influence or management practice. (SRM)

Indicator species: A species whose presence or absence is indicative of a particular habitat, community or set of environmental conditions.

Interest group: Any group, formal or otherwise, with a specialized set of shared preferences about how resources should be used or allocated.

Introduced species: A species not part of the original fauna or flora of the area in question (see Exotic species). (SRM)

Lek: Traditional arenas where male prairie grouse, e.g., sage grouse, gather during early spring to conduct a courtship display, attract females, and breed. For sage grouse, the lekking arena often is referred to as a "strutting ground."

Legal mandate: Any policy set by legislative action at either the federal or state level.

Light grazing: A comparative term that indicates that the stocking rate of one pasture is relatively less than that of other pastures. (SRM)

Local impact: The effect of an action in the immediate vicinity of the action. 
Long-term: An action, trend, or impact that lasts long enough to affect the potential of a species to maintain its population through reproduction or immigration.

MEPA: Montana Environmental Policy Act (75-1-101, MCA) which is patterned after the National Environmental Policy Act (NEPA).

Memorandum of Understanding (MOU): An agreement between or among governmental agencies that specifies each agency's authorities and responsibilities in areas of mutual interest.

Mitigation: An action undertaken to avoid, minimize, rectify, reduce, or compensate for an adverse impact.

Moderate grazing: A comparative term, which indicates that the stocking rate of a pasture is between the rates of other pastures. Often erroneously used to mean proper use. (SRM)

Monitor: To observe and record the activities or results of a particular project, population, or operation.

Multiple use: Use of range for more than one purpose, i.e., grazing of livestock, wildlife production, recreation, watershed and timber production. Not necessarily the combination of uses that will yield the highest economic return or greatest unit output. (SRM)

Multiple-use management: The concept of managing public land for a variety of objectives.

NEPA: National Environmental Policy Act of 1969. This is the basic national charter for protection of the environment. It establishes policy, sets goals (Section 101), and provides means (Section 102) for carrying out the policy. (40 CFR 1500.1) The Montana Environmental Policy Act was modeled after NEPA. Federally funded activities of public agencies must comply with NEPA (see MEPA).

Native species: Species that occur or evolve naturally, without human intervention or manipulation, e.g., sage grouse (see Natural dispersal).

Natural dispersal: Movement by individual animals beyond the limits of the natal range that could result in establishment of a population.

Natural sex and age structure: The distribution of animals in a population by sex and age that is not influenced by hunting, trapping, or culling of any other kind.

No surface occupancy: Use or occupancy of the land surface for fluid mineral exploration or development is prohibited to protect identified resource values.

No surface use: Use of the land surface for fluid mineral exploration or development is protected during certain time periods to protect identified resource values. This does not apply to on-going production. 
Noxious weed: Any exotic plant species established or that may be introduced in the state, which may render land unfit for agriculture, forestry, livestock, wildlife, or any other beneficial uses or that may harm native plant communities (see "The County Noxious Weed Control Act or 1979, MCA 7-22-21-1).

Optimal harvest rate: a hunting harvest rate that is in balance with recreation and sage grouse conservation.

Overgrazing: Continued heavy grazing that exceeds the recovery capacity of the community and creates a deteriorated range. (SRM)

Overuse: Utilizing an excessive amount of the current year's growth, which, if continued, will result in range deterioration. (SRM)

Population: A group of organisms of the same species that occupies a particular area.

Population management: The process of manipulating wildlife populations to meet an objective.

Potential Natural Vegetation: A historical term originally defined by A. W. Kuchler as the stable vegetation community that could occupy a site under current climatic conditions without further human influence. Often used interchangeably with Potential Natural Community. (SRM)

Potential Plant Community: One of usually several plant communities that may become established on an ecological site under the present environmental conditions, either with or without interference by man. (SRM)

Predator: A legal designation by Montana statute including coyote, weasel, skunk, and civet cat. Other animals are predatory in that they feed on other animals but are designated by state law as game, furbearers, or nongame.

Proper use: A degree of utilization of current year's growth, which if continued will achieve management objectives and maintain or improve long-term productivity of the site. Proper use varies with time and grazing systems. Syn. proper utilization, proper grazing use, cf. allowable use. (SRM)

Proper Use Factor: An index to the grazing use that may be made of a specific forage species, based on a system of range management that will maintain the economically important forage species, or achieve other management objectives such as maintenance of watersheds, recreation values, etc. (SRM)

Public land: Land that is owned and controlled by a governmental unit, i.e., federal, state, county, or other municipal jurisdiction, designated for public use. 
Rangeland health: The degree to which the integrity of the soil, vegetation, water, and air as well as ecological processes of a rangeland ecosystem is balanced and sustained. (SRM)

Rangeland integrity: Maintenance of the structure and functional attributes characteristic of a particular locale, including normal variability. (SRM)

Range improvement: Any activity or program on or relating to rangelands that is designed to improve production of forage, change vegetation composition, control patterns of use, provide water, stabilize soil and water conditions, or provide habitat for livestock and wildlife. $(S R M)$

Raptors: Carnivorous bird species, such as owls, hawks, and falcons, that prey on other birds, amphibians, reptiles, and mammals.

Resident species: Animal species that do not normally migrate in response to seasonal changes and are generally managed by state agencies.

Riparian area: A type of habitat occurring along the bank of a watercourse or other water body typically consisting of water tolerant trees and shrubs such as alder, cottonwood, and willows. Many riparian areas occur as bands of vegetation along a watercourse, often called riparian corridors.

Sage grouse: A member of the family Phasianidae and the largest member of North American grouse, i.e., subfamily Tetraoninae, of which distribution is restricted to the sagebrush steppe in the western part of the continent (see Upland gamebirds).

Sagebrush: Includes several species of genus Artemisia that occur in Montana, e.g., Wyoming big sagebrush (A. tridentata tridentata), mountain big sagebrush (A.t. vaseyana), and silver sagebrush (A. cana).

Sagebrush Alliance: a physiognomically uniform group of associations sharing one or more dominant or diagnostic species, i.e., sagebrush, found in the uppermost strata of vegetation. Dominant species are often emphasized in the absence of detailed floristic information, e.g., quantitative plot data, whereas diagnostic species, e.g., characteristic species, dominant, differential, and other species groupings based on constancy, are used where detailed floristic data are available

Sagebrush habitat type: Environments with the potential of supporting sagebrush at climax (see Sagebrush).

Seasonal grazing: Grazing restricted to one or more specific seasons of the year. (SRM)

Seasonal use: (1) Synonymous with seasonal grazing. (2) Seasonal preference of certain plant species by animals. $(S R M)$

Short-term: An action, trend, or impact that does not last long enough to affect the reproductive or survival capabilities of a species. 
Species of special concern: A Montana Natural Heritage Program designation for species that may be very rare or locally abundant but occupying a very restricted range. In either case, they are especially vulnerable to extinction.

Steppe: Regions with moisture relations adequate to support an appreciable cover of perennial grasses on zonal soil, yet not enough for arborescent vegetation (Daubenmire 1970).

Succession: The more or less predictable changes in the composition of communities following natural or human disturbance.

Suspension fence: Non-woven wire fence comprised of high tension wire supported by rigid stays and widely spaced posts to which wire is not firmly attached. (SRM)

Sustained yield (of wildlife): The long-term harvest of wildlife for food, economic benefit, or recreation; a management goal.

Target species/animal/population: A wildlife species or population to which management actions are directed.

Technical assistance: Advice, recommendations, information, and materials provided for others to use in managing wildlife.

Threatened species: A designation under the federal ESA for species likely to become an endangered species within the foreseeable future throughout all or a significant portion of its range.

Transmission lines: Power lines that transmit large blocks of energy (115 KV or higher) for distribution to various customers. (APLIC)

Underuse: A degree of use less than proper use. (SRM)

Upland game birds: A legal designation by Montana statute that includes sharp-tailed grouse, blue grouse, spruce grouse, prairie chicken, sage grouse, ruffed grouse, quail, pheasant, Hungarian (gray) partridge, ptarmigan, wild turkey, and chukar partridge (87-2-101 MCA).

Use: (1) The proportion of current year's forage production that is consumed or destroyed by grazing animals. May refer either to a single species or to the vegetation as a whole. Syn. degree of use (2) Utilization of range for a purpose such as grazing, bedding, shelter, trailing, watering, watershed, recreation, forestry, etc. (SRM)

Wildlife: Any wild mammal, bird, amphibian, or reptile.

Wildlife conservation: Wise use of wildlife resources.

Wildlife habitat: See Habitat. 
Wildlife management: The science and art of maintaining or altering the characteristics and interactions of habitats, animal populations, and humans to achieve specific human goals.

Wildlife refuges: Land set aside to protect certain species of fish or wildlife (administered at the federal level by the U.S. Fish and Wildlife Service).

\section{ABBREVIATIONS}

\begin{tabular}{|c|c|}
\hline APLIC & Avian Power Line Interaction Committee \\
\hline BLM & U.S. Bureau of Land Management \\
\hline ESA & Endangered Species Act \\
\hline FHWA & Federal Highway Administration \\
\hline FWP & Montana Fish, Wildlife and Parks \\
\hline MEPA & Montana Environmental Policy Act \\
\hline MDOT & Montana Department of Transportation \\
\hline MOU & Memorandum of Understanding \\
\hline NEPA & National Environmental Policy Act \\
\hline NIFC & National Interagency Fire Center \\
\hline NRIS & Natural Resource Information System \\
\hline SRM & Society for Range Management \\
\hline USDA & U.S. Department of Agriculture \\
\hline USDI & U.S. Department of the Interior \\
\hline USFS & U.S. Forest Service \\
\hline USFWS & U.S. Fish and Wildlife Service \\
\hline
\end{tabular}

WAFWA Western Association of Fish and Wildlife Agencies 


\section{MEETING PARTICIPANTS}

\section{Individuals who have participated in the Montana Sage Grouse Work Group}

\begin{tabular}{|c|c|c|}
\hline NAME & AFFILIATION & ADDRESS \\
\hline Gail Abercrombie & Montana Petroleum Association & \\
\hline Debbie Barret & Rancher & Dillon \\
\hline Chris Beebe & Montana Wildlife Federation & Helena \\
\hline Jay Bodner & Montana Stockgrowers & \\
\hline Bob Brannon & Montana Fish, Wildlife \& Parks & Sheridan \\
\hline Ross Bruner & & Bozeman \\
\hline Susan Bury & Contractor to FWP & Red Lodge \\
\hline John Carlson & Montana Natural Heritage Program & Helena \\
\hline Scott Cassel & Rancher & Saco \\
\hline Ben Conard & USDA Forest Service & \\
\hline Bill Darwin & Rancher & \\
\hline Ben Deeble & National Wildlife Federation & Missoula \\
\hline JoAnn Dullum & USDI Fish \& Wildlife Service & Lewistown \\
\hline Gary Dusek & Montana Fish, Wildlife \& Parks & Bozeman \\
\hline John Ensign & Montana Fish, Wildlife \& Parks & Miles City \\
\hline Charlie Eustace & Montana Fish, Wildlife \& Parks & Billings \\
\hline Roxanne Falise & USDI Bureau of Land Management & Billings \\
\hline Mark Goetz & North Range Research & Great Falls \\
\hline John Gonzales & USDI Bureau of Land Management & \\
\hline Jim Hagenbarth & Rancher & Dillon \\
\hline Ross Hansen & Rancher & \\
\hline Bernard Harkness & Rancher & Dillon \\
\hline Jean Harkness & Rancher & Dillon \\
\hline Jeff Herbert & Montana Fish, Wildlife \& Parks & Helena \\
\hline Janet Hess-Herbert & Montana Fish, Wildlife \& Parks & Helena \\
\hline Glenn Hockett & Gallatin Wildlife Association & Bozeman \\
\hline Peter Husby & Natural Resources Conservation Service & Bozeman \\
\hline Shannon Iverson & USDI Bureau of Land Management & Lewistown \\
\hline Ray Johnson & Montana Audubon & Helena \\
\hline Dennis Kavanaugh & & Bozeman \\
\hline Steve Knapp & Montana Fish, Wildlife \& Parks & Helena \\
\hline Maxine Korman & Rancher & Hinsdale \\
\hline Scott Kulbeck & Montana Farm Bureau & \\
\hline John Lacey & Rancher & \\
\hline Susan Lenard & Montana Audubon & Helena \\
\hline Gilbert Little & Rancher & \\
\hline Brian Logan & USDA Forest Service & Stanford \\
\hline Tom Lowry & Montana Stockgrowers/Rancher & \\
\hline Mary Maj & USDA Forest Service & \\
\hline John Maki & Beaverhead County Agent & Dillon \\
\hline Jina Mariani & USDA Forest Service, Region 1 & Missoula \\
\hline Randy Matchett & USDI Fish \& Wildlife Service & CMR \\
\hline John McCarthy & Montana Fish, Wildlife \& Parks & Helena \\
\hline
\end{tabular}




\begin{tabular}{|c|c|c|}
\hline NAME & AFFILIATION & ADDRESS \\
\hline Bill McIlvane & USDI Bureau of Land Management & \\
\hline Sam Milodragovich & NorthWestern Energy & Butte \\
\hline John Moorhouse & USDI Bureau of Land Management & \\
\hline Larry Murphy & Natural Resources Conservation Service & \\
\hline Lori Nordstrom & USDI Fish \& Wildlife Service & Helena \\
\hline Rick Northrup & Montana Fish, Wildlife \& Parks & Malta \\
\hline Jeff Pattison & Montana Legislature & \\
\hline Joel Peterson & Montana Fish, Wildlife \& Parks & Bozeman \\
\hline Steve Pilcher & Montana Stockgrowers & Helena \\
\hline \multicolumn{3}{|l|}{ Randy Piper } \\
\hline Kim Reid & USDA Forest Service, Custer NF & Billings \\
\hline Ralph Rogers & North America Grouse Partnership & \\
\hline Paul Rubright & Gallatin Wildlife Association & Bozeman \\
\hline Bill Pryor & Montana Fish, Wildlife \& Parks & Billings \\
\hline Tom Rice & Rancher & \\
\hline Craig Roberts & DNRC-NE Land Office & Lewistown \\
\hline Clive Rooney & DNRC-NE Land Office & Lewistown \\
\hline Al Rosgaard & Montana Fish, Wildlife \& Parks & Havre \\
\hline Jay Rotella & Ecology, MSU & Bozeman \\
\hline Patti Rowland & Southwest Stockgrowers & Dillon \\
\hline Jane Roybal & USDI Fish \& Wildlife Service & Lewistown \\
\hline Brad Sauer & USDI Bureau of Land Management & Lewistown \\
\hline Dan Spencer & Fort Belknap Tribes & Ft. Belknap \\
\hline Fred Samson & USDA Forest Service, Region 1 & Missoula \\
\hline Marc Scow & Montana Fish, Wildlife \& Parks & Helena \\
\hline Mark Stevens & Rancher & Ashland \\
\hline Tom Stivers & Montana Fish, Wildlife \& Parks & Lewistown \\
\hline Ron Stoneberg & Montana Fish, Wildlife \& Parks & Hinsdale \\
\hline Dan Sullivan & Montana Department of Agriculture & Helena \\
\hline Shannon Taylor & & Bozeman \\
\hline J. T. "Skip" Tubbs & Montana Falconers Association & Bozeman \\
\hline Kent Undlin & USDI Bureau of Land Management & Miles City \\
\hline Tim Vosberg & Fort Belknap Tribes & Ft. Belknap \\
\hline Carl Wambolt & Range and Animal Sciences, MSU & Bozeman \\
\hline John Weigand & Headwaters Wildlife Association & Bozeman \\
\hline Harold Wentland & Montana Fish, Wildlife \& Parks & Glasgow \\
\hline Mark Whisler & USDI Bureau of Land Management & \\
\hline Tom Whitford & USDA Forest Service, Custer NF & Billings \\
\hline Rebecca Wood & Montana Stockgrowers & \\
\hline
\end{tabular}




\section{AGENCY SIGNATORIES}

The signatories to this management plan agree to honor their commitments, as described in Section II of this document, and implement the conservation strategies contained herein within the constraints imposed by annual budgets, available staff, and agency responsibilities. Nothing within this management plan is intended to supercede any laws, regulations, policies or directives that mandate and guide management of participating agencies.

M. Jeff Hagener, Director

Montana Fish, Wildlife \& Parks

P.O. Box 200701

Date

Helena, MT 59620

Bud Clinch, Director

Montana Natural Resources and Conservation

PO Box 201601

Date

Helena, MT 59620-1601

Abigail R. Kimbell, Regional Forester

USDA, Forest Service, Regional Office

200 E. Broadway

Date

Missoula, MT 59807

Marty Ott, State Director

USDI, Bureau of Land Management

Montana State Office

Date

5001 Southgate Dr

Billings, Montana 59101

Dave White, State Conservationist

USDA, Natural Resources and Conservation Service

10 East Babcock Street, Room 443

Date

Bozeman, MT 59715-4704 


\section{PARTICIPATING NON-GOVERNMENTAL ORGANIZATIONS OR PRIVATE SECTOR STAKEHOLDERS}

The following non-governmental organizations have been involved in development of this management plan and will work to support the plan's implementation.

Ben Deeble, Sage-grouse Project Coordinator

National Wildlife Federation

240 N. Higgins Ave. \#2

Date

Missoula, MT 59802

Mark Goetz

CVO

North Range Research and Consulting

Date

Great Falls, MT

Craig Sharpe, Executive Director

Montana Wildlife Federation

www.montanawildlife.com

Date

J.T. "Skip" Tubbs, Past President Current Sec. Treas.

Montana Falconers Association

P.O. Box 10833

Date

Bozeman, MT 59719-0833 


\section{APPENDICES}
A. WAFWA Guidelines
B. Habitat Assessment Tools
C. Adaptive Harvest Strategy
D. Lek Monitoring Tools
E. Summary of Public Comments with Responses 


\section{APPENDIX A. \\ WAFWA GUIDELINES}

Guidelines to manage Sage Grouse populations and their habitats.

Connelly, J. W., M. A. Schroeder, A. R. Sands, and C. E. Braun. 2000.

Wildlife Society Bulletin 28:967-985.

The article is copied in its entirety with permission from The Wildlife Society. 


\section{APPENDIX B.}

\section{HABITAT ASSESSMENT TOOLS}

\section{Work Sheets and Instructions}

Sage Grouse Habitat Assessment Worksheet - Breeding Habitat

Sage Grouse Habitat Assessment Worksheet - Late Brood-rearing

Sage Grouse Habitat Assessment Worksheet - Winter Habitat

Line Intercept and Daubenmire Frame Data Form for Sage Grouse Evaluations

Shrub Line Intercept Canopy Cover

Daubenmire Cover Class \& Vegetation Height Data

Line Point Transect Data Form for Sage Grouse Evaluations

Site Forb Abundance Form for Sage Grouse Evaluations

Sage Grouse Habitat Summary Evaluation Sheet 


\section{Sage Grouse Habitat Assessment Worksheet - Breeding Habitat}

\begin{tabular}{|c|c|c|c|c|c|c|}
\hline Date: & \multicolumn{6}{|c|}{ Project or Allotment Name/\#: } \\
\hline \multicolumn{3}{|l|}{ Pasture Name/\#: } & \multicolumn{2}{|l|}{ Site \#: } & \multirow{2}{*}{\multicolumn{2}{|c|}{$\begin{array}{l}\text { FO: } \\
\text { GPS File \#: }\end{array}$}} \\
\hline Legal Description: T. $\quad \mathbf{R}$ & - Section , & & $1 / 4$ & & & \\
\hline \multicolumn{7}{|l|}{ Other Location Info: } \\
\hline \multicolumn{3}{|l|}{ Evaluator(s): } & \multicolumn{4}{|l|}{ HUC \#: } \\
\hline \multicolumn{5}{|c|}{$\begin{array}{l}\text { Cover Type (circle one): Sagebrush, Perennial Grassland (native, introduced), } \\
\text { Sagebrush, Annual Grassland, Juniper Area }\end{array}$} & \multicolumn{2}{|c|}{ Annual Grassland with } \\
\hline Habitat Indicator & Suitable Habitat & $\checkmark$ & Marginal Habitat & $\checkmark$ & $\begin{array}{c}\text { Unsuitable } \\
\text { Habitat }\end{array}$ & $\checkmark$ \\
\hline $\begin{array}{l}\text { Average Big Sagebrush } \\
\text { Canopy Cover }\end{array}$ & $\geq 15 \%$ but $\leq 25 \%$ & & $10-14 \%$ or $26-35 \%$ & & $<10 \%$ or $>35 \%$ & \\
\hline $\begin{array}{l}\text { Average Big Sagebrush } \\
\text { Height }\end{array}$ & $12-30^{\prime \prime}$ & & $10-14 "$ or $31-40 "$ & & $<10^{\prime \prime}$ or $>40^{\prime \prime}$ & \\
\hline $\begin{array}{l}\text { Big sagebrush growth } \\
\text { form }\end{array}$ & $\begin{array}{l}\text { Spreading form, } \\
\text { few, if any, dead } \\
\text { branches for most } \\
\text { plants }\end{array}$ & & $\begin{array}{l}\text { Mix of spreading } \\
\text { and columnar } \\
\text { growth forms } \\
\text { present }\end{array}$ & & $\begin{array}{l}\text { Tall, columnar } \\
\text { growth form with } \\
\text { dead branches for } \\
\text { most plants }\end{array}$ & \\
\hline $\begin{array}{l}\text { Average herbaceous grass } \\
\text { and forb height }\end{array}$ & $\geq 7^{\prime \prime}$ & & $5-7 "$ & & $<5^{\prime \prime}$ & \\
\hline $\begin{array}{l}\text { Average grass canopy } \\
\text { cover }\end{array}$ & $\geq 15 \%$ & & $5-14 \%$ & & $<5 \%$ & \\
\hline $\begin{array}{l}\text { Average forb canopy } \\
\text { cover }\end{array}$ & $\geq 10 \%$ & & $5-9 \%$ & & $<5 \%$ & \\
\hline Forb richness ${ }^{1}$ & High & & Low & & Very low & \\
\hline \multicolumn{7}{|l|}{ Overall Site Evaluation } \\
\hline \multicolumn{7}{|l|}{ Comments: } \\
\hline
\end{tabular}

${ }^{1}$ Relative to site potential and site guides. 


\section{General Directions:}

1. Sites should be located on flat to slightly sloping lands. Slopes greater than $40 \%$ are unsuitable nesting habitat.

2. Breeding habitat must be evaluated as close to the end of nesting as possible (May- June). For low elevation areas this will be May, for higher elevation areas it will be June.

3. Precipitation can affect annual forb growth - if precipitation is an interpretation factor then this should be noted in the comment section.

4. Good nesting habitat may be provided disproportionately in small inclusions of big sagebrush surrounded by low sagebrush. In these situations nesting conditions should be measured in the big sagebrush patches. However, the low sagebrush community likely provides important pre-nesting and early brood-rearing habitat and should be evaluated for the forb composition indicators (canopy cover and diversity).

\section{Worksheet Directions:}

Fill out all site location information at top of sheet.

HUC \#: Use $5^{\text {th }}$ field hydrologic unit.

Each indicator must be marked as suitable, marginal or unsuitable. Numeric values should be written when quantitative data are collected. Qualitative evaluations should only have a $\checkmark$ in the box.

If site potential is a factor for an indicator being either marginal or unsuitable put an asterisk $\left(^{*}\right)$ by the indicator and discuss in the comments section. Referencing site potential as per the site guides is recommended.

Overall site evaluation is based on professional judgement, not all indicators need to be in the suitable range for an overall suitable evaluation. Where needed, explain rationale in comments section.

If site potential is a factor for an overall evaluation of marginal or unsuitable put an asterisk(*) after "Overall Site Evaluation" in the last row. Explain rationale in notes section.

\section{Complete the Site Forb Abundance Form.}

Attach field data sheet(s) used for this site evaluation.

Worksheet should be filled out for areas identified as important late brood-rearing habitats during fine-scale review.

Riparian areas and wet meadows located in deep canyon should not be considered brood-rearing habitat. Evaluation sites should not be located in designated livestock stream crossings or water gaps. 


\section{Sage Grouse Habitat Assessment Worksheet - Late Brood-rearing}

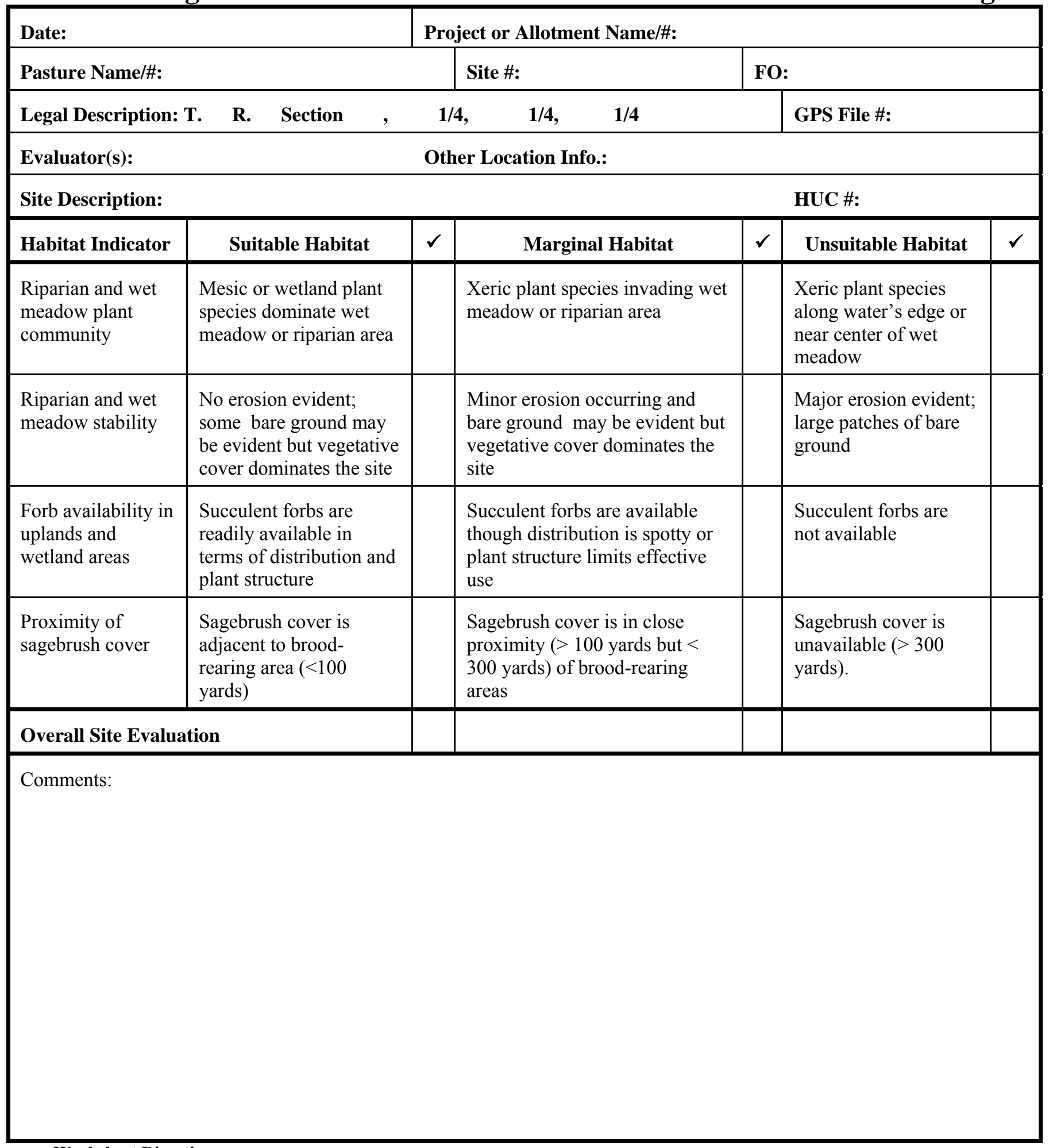

Worksheet Directions:

Site Description: Identify what type of habitat is being evaluated: riparian area, wet meadow, lakebed, sagebrush area adjacent to agricultural field, etc.

HUC \#: Use $5^{\text {th }}$ field hydrologic unit (watershed).

Put a $\checkmark$ in the appropriate suitability category for each indicator that best describes the site.

Forb availability and plant structure: In some cases forbs may be present on the site but trampling or grazing intensity may affect availability. 


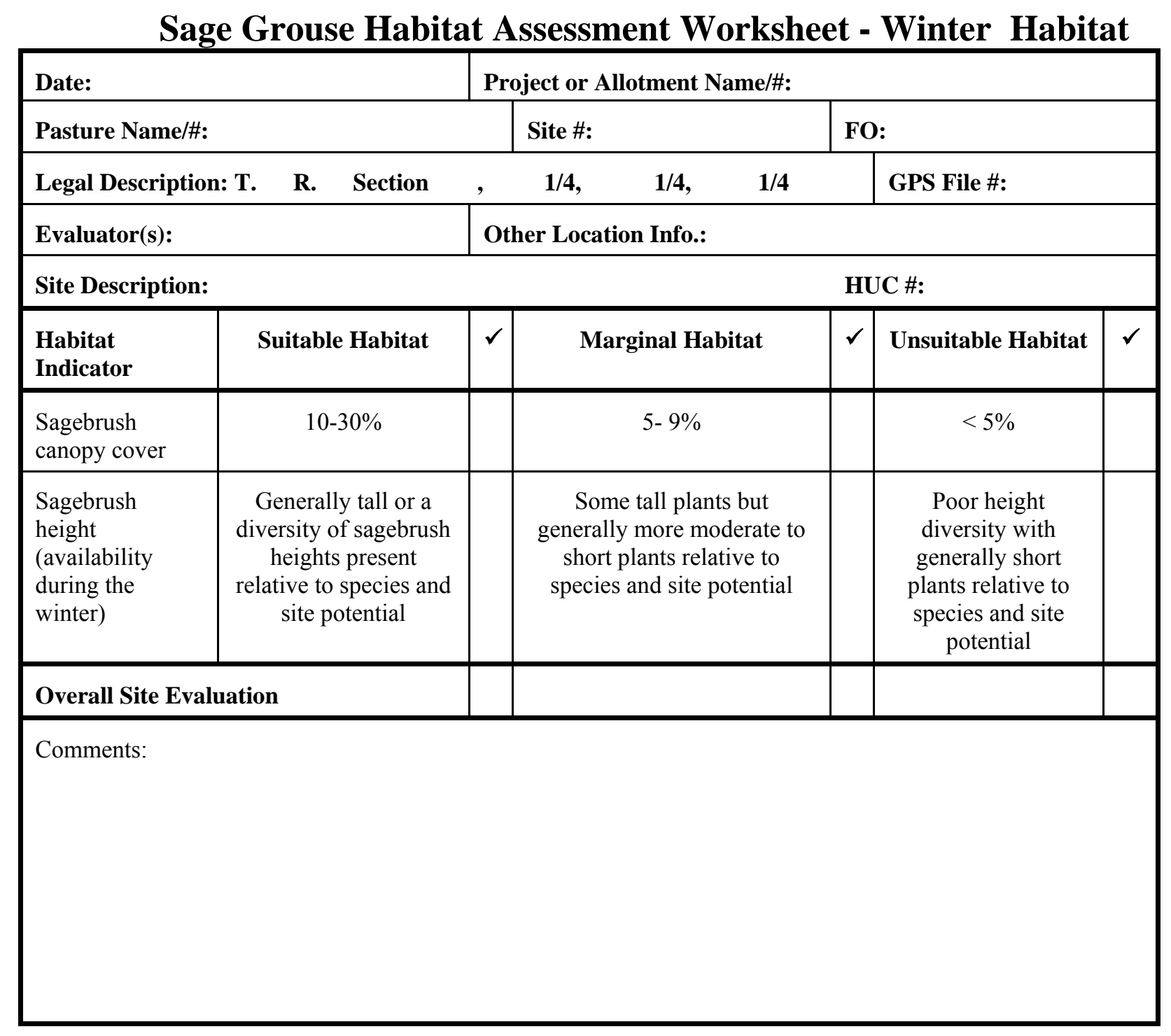

\section{General Directions:}

Form should be completed for areas that were identified as winter areas during the fine-scale review.

\section{Worksheet Directions:}

Site Description: provide a brief description of the site.

HUC \#: Use $5^{\text {th }}$ field hydrologic unit.

Sagebrush Canopy Cover: Insert the canopy cover into the appropriate suitability box. If it was measured using line intercept or line point transect put in the measured value. If you visually estimated the percent then use the $\checkmark$.

Sagebrush Height: Measuring sagebrush heights above the snow during the winter would be difficult for many areas. Since the evaluation site is located in a known or suspected wintering area sagebrush heights in the area relative to sagebrush species and ecological site is an important habitat indicator. Put a $\checkmark$ in the appropriate suitability category that best describes the site. 


\section{Equipment:}

\section{Protocol for Line Intercept Transect and Daubenmire Frames}

Data Forms and Worksheets

Tape, 100-foot

Stakes for tape (at least two spikes; old, medium-large screwdrivers work well)

Daubenmire frame $20 \times 50 \mathrm{~cm}$

Yardstick (for measuring shrub and grass/forb heights)

Compass

Random numbers table, wristwatch with second hand, or calculator with random function etc.

Camera and print film, extra camera battery; extra film.

Photo cards and markers; or small dry-erase board and marker

Topographic map with project area, general cover types, and pasture boundaries delineated

Aerial photographs

Soil Survey/Ecological Site Guides

GPS unit

Pencils

Colored pencils for sketching plant communities

Calculator

\section{Protocol:}

1. Sites have been selected stratified by major cover type and pasture (see framework document for directions).

2. Randomly select a compass azimuth, using a random numbers generator, wristwatch with second hand, or other objective means. Make sure transect is at least 0.25 miles from disturbances such as roads, water sources etc.

3. Anchor a 100-foot tape with a stake (spike, screwdriver, etc.) and extend it snugly along the random azimuth. Secure end with a second stake.

4. As a minimum, accurately locate the transect's location on a 1:24000 USGS map. Use GPS and differentially correct if at all possible. It will be important to be able to return to the area for follow up monitoring or photos in some instances.

5. On the data form, record shrub canopy cover by species using the line intercept method. Record cover increments to the nearest $0.1 \mathrm{ft}$. Record only live (green) canopy. Ignore spaces or gaps in the canopy less than 2 inches across. Gaps in the live canopy in excess of 2 inches will not be included as canopy intercepts. It may also be helpful to separately record dead/decadent shrub cover if it appears to be a significant component of the community; however only live sagebrush cover will be of consequence to the habitat assessment for sage grouse.

6. At each 5-foot increment along the tape:

a. Place a $20 \times 50 \mathrm{~cm}$ Daubenmire frame $(\mathrm{n}=20$ plots per transect). For each plot, estimate and record cover for perennial grasses, annual grasses, perennial forbs, annual forbs. Note predominant species.

b. Record to the nearest inch the maximum height of the nearest sagebrush plant.

c. At each 5-foot increment point record the maximum "natural" height of the nearest perennial grass or perennial forb plant part within a 2.5 -foot, $180^{\circ}$ arc around the point that ends at the tape line. If no plants are within this arc then record a dash and move on to next point. [Natural = the highest point of a leaf or seed stalk is measured with no straightening by the observer]

7. Summarize data at the bottom of each form.

8. Photographs. At least one photograph must be taken at each transect/ evaluation area. Photos will prove invaluable in locating evaluation areas in subsequent years. They will also be of substantial utility in the office when preparing evaluation documents and documenting habitat condition.

a. Complete a Photo Card, showing, as a minimum, the date, location, allotment, and sagebrush canopy cover percentage.

b. With the photo card near the "zero" end of the tape, take a general photo of the area, sighting down the tape from eye level, showing landmarks in the background, if possible.

c. In a representative location along or near the tape, place the photo card near the base of a sagebrush plant, and take a tangential close-up photo from near ground level (2-3 ft) toward the shrub/ground interface, to document herbaceous conditions and cover.

d. Optional: take one or more other close-ups or panoramic photos as needed.

9. Depending on the complexity of the evaluation area, several line transects within a cover type may be necessary to characterize the area using this technique.

10. Complete the Site Forb Abundance Form. 
Line Intercept and Daubenmire Frame Data Form for Sage Grouse Evaluations

\begin{tabular}{|l|l|l|l|}
\hline Date: & \multicolumn{4}{l|}{ Project or Allotment Name/\#: } & FO: \\
\hline Pasture Name/\#: & \multicolumn{1}{l|}{ Site \#: } & GPS File \#: \\
\hline Legal Description: T. $\quad$ R. Section $\quad 1 / 4, \quad 1 / 4, \quad 1 / 4$ & Permanent Transect?: \\
\hline Other Location Info.: & Transect Length: & \\
\hline Examiner(s): &
\end{tabular}

Shrub Line Intercept Canopy Cover

\begin{tabular}{|l|l|l|l|}
\hline Shrub Species & Intercept (feet) & Total & \% Cover \\
\hline & & & \\
\hline & & & \\
\hline & & & \\
\hline & & & \\
\hline
\end{tabular}

\begin{tabular}{|c|c|c|c|c|c|c|c|c|c|c|c|c|c|c|c|c|c|c|c|c|}
\hline \multicolumn{21}{|c|}{ Daubenmire Cover Class \& Vegetation Height Data (recorded at 5-foot intervals) } \\
\hline \multirow[t]{2}{*}{ Cover Type } & \multicolumn{20}{|c|}{ Estimated Cover Class for Each Plot* } \\
\hline & 1 & 2 & 3 & 4 & 5 & 6 & 7 & 8 & 9 & 10 & 11 & 12 & 13 & 14 & 15 & 16 & 17 & 18 & 19 & 20 \\
\hline \multicolumn{21}{|c|}{ Perennial Grass } \\
\hline \multicolumn{21}{|l|}{ Annual Grass } \\
\hline \multicolumn{21}{|l|}{ Perrenial Forb } \\
\hline Annual Forb & & & & & & & & & & & & & & & & & & & & \\
\hline
\end{tabular}

*Cover Classes: 1=0-5\%, 2=6-15\%, 3=16-25\%, 4= 26-50\%, 5=51-75\%, 6=76-95\%, 7=96-100\%

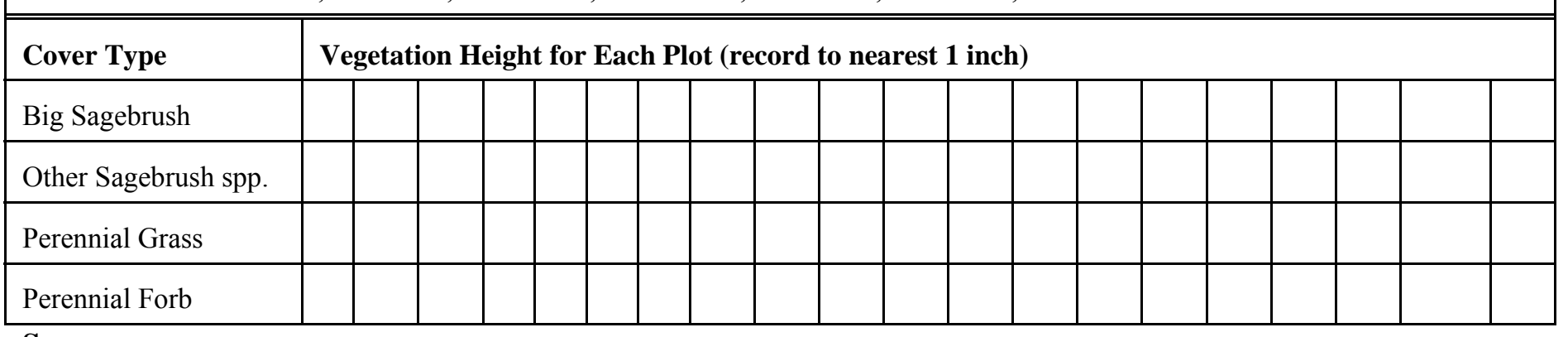

\begin{tabular}{|l|l|l|l|l|}
\hline \multicolumn{5}{|l|}{ Summary } \\
Cover Class: & Big Sagebrush: & Other Sagebrush: & P. Grasses: & A. Grasses: \\
\cline { 2 - 5 } & Perennial Forbs: & Annual Forbs: & & \\
\hline \hline Vegetation Height: & Big Sagebrush Mean Ht. & All Shrubs Mean Ht.: \\
\hline & Perennial Grass Mean Ht.: & Perennial Forb Mean Ht.: \\
\hline
\end{tabular}




\section{Line-Point Intercept Method (transect or step-point techniques)}

\section{Equipment:}

Data Forms and Worksheets

Tape, 100-foot (optional)

Stakes for tape (at least two spikes; old, medium-large screwdrivers work well)

Pin flag or Pointer: straight piece of wire or rod at least 30 " long and less than $2.5 \mathrm{~mm}$ in diameter

Yardstick (for measuring shrub and grass/forb heights)

Compass

Random numbers table, wristwatch with second hand, or calculator with random function etc.

Camera and print film, extra camera battery; extra film.

Photo cards and markers; or small dry-erase board and marker

Topographic map with project area, general cover types, and pasture boundaries delineated

Aerial photographs

Soil Survey/Ecological Site Guides

GPS unit

Pencils

Colored pencils for sketching plant communities

Calculator

\section{Protocol:}

Sites have been stratified by major cover types and pastures prior to field evaluation (see framework document for more directions).

\section{If you use a tape:}

1. Anchor the tape with a steel pin and pull tape out 100 feet. Keep tape as taught and straight as possible. Anchor tape on far end.

2. Begin at " 0 " end of tape.

3. Every 2 feet drop the pin flag or pointer to the ground so that it falls precisely vertically and touches the near side of the tape at the correct mark (every 2 feet for 50 marks).

4. Record the lifeform (codes at bottom of form) of the herbaceous plants and species of sagebrush with the highest live leaf or stem touching the pin to the nearest inch. Record only live canopies of shrubs and live or residual herbaeous plants.

5. If the pin is dropped within the canopy of a live sagebrush plant record the maximum height for that shrub.

6. Record the heights of the live or residual herbaceous plants that touch the pin.

7. Record the lifeform and height of the plant with next highest live or residual leaf or stem touching the pin. Record these under the "Lower Layers" columns.

8. Repeat Step 7 for all live or residual canopy, recording each lifeform of interest only once.

9. Proceed to next intercept and repeat. Fifty sample points are the minimum recommended number for fairly homogenous vegetation. More points may be needed for heterogeneous vegetation.

10. Summarize data at the bottom of each form.

11. Photographs. At least one photograph must be taken at each transect/ evaluation area. Photos will prove invaluable in locating evaluation areas in subsequent years. They will also be of substantial utility in the office when preparing evaluation documents and documenting habitat condition.

a. Complete a Photo Card, showing, as a minimum, the date, location, allotment, and sagebrush canopy cover percentage.

b. With the photo card near the "zero" end of the tape, take a general photo of the area, sighting down the tape from eye level, showing landmarks in the background, if possible.

c. In a representative location along or near the tape, place the photo card near the base of a sagebrush plant, and take a tangential close-up photo from near ground level (2-3 ft) toward the shrub/ground interface, to document herbaceous conditions and cover.

d. Optional: take one or more other close-ups or panoramic photos as needed.

12. Complete the Site Forb Abundance Form. 


\section{If you use step-point method:}

1. Mark the starting point with a steel post or pin and record compass bearing.

2. Determine the number of paces between points prior to starting. If the area you are evaluating is large then you may want to have more paces between points in order to cover more land area.

1. Select a focal point on the horizon to focus on.

2. Take the selected number of paces toward the focal point staying on a straight line. You must walk in a straight line through sagebrush or other shrubs. If this is difficult to do, it's recommended that you use a tape to help you stay on a straight line. Drop the pin flag just out from the tip of your foot so that it falls precisely vertical.

5. Follow direction 4-12 under the above line transect directions. 
Line Point Transect Data Form for Sage Grouse Evaluations

\begin{tabular}{|c|c|c|c|c|c|c|}
\hline Date: & & \multicolumn{5}{|c|}{ Project or Allotment Name/\#: } \\
\hline \multicolumn{5}{|l|}{ Pasture Name/\#: } & Site\#: & FO: \\
\hline Legal Description: $\mathrm{T}$. & $\mathrm{R}$. & Section & , $\quad 1 / 4$ & $1 / 4$ & $1 / 4$ & GPS File \#: \\
\hline \multicolumn{5}{|l|}{ Cover Type: } & \multicolumn{2}{|c|}{ Tape or Pace Transect? (circle one) } \\
\hline \multicolumn{5}{|l|}{ Examiner(s): } & \multicolumn{2}{|c|}{ Location Info.: } \\
\hline
\end{tabular}

\begin{tabular}{|c|c|c|c|c|c|c|c|c|c|c|c|c|c|}
\hline \multirow{3}{*}{ Points } & \multirow{2}{*}{\multicolumn{2}{|c|}{ Top Layer }} & \multicolumn{4}{|c|}{ Lower Canopies } & \multirow{3}{*}{ Points } & \multirow{2}{*}{\multicolumn{2}{|c|}{ Top Layer }} & \multicolumn{4}{|c|}{ Lower Canopies } \\
\hline & & & \multicolumn{2}{|c|}{ Layer 2} & \multicolumn{2}{|c|}{ Layer 3} & & & & \multicolumn{2}{|c|}{ Layer 2} & \multicolumn{2}{|c|}{ Layer 3} \\
\hline & Hits & Heigh & Hits & Heigh & Hits & Heigh & & Hits & Heigh & Hits & Heigh & Hits & Heigh \\
\hline 1 & & & & & & & 26 & & & & & & \\
\hline 2 & & & & & & & 27 & & & & & & \\
\hline 3 & & & & & & & 28 & & & & & & \\
\hline 4 & & & & & & & 29 & & & & & & \\
\hline 5 & & & & & & & 30 & & & & & & \\
\hline 6 & & & & & & & 31 & & & & & & \\
\hline 7 & & & & & & & 32 & & & & & & \\
\hline 8 & & & & & & & 33 & & & & & & \\
\hline 9 & & & & & & & 34 & & & & & & \\
\hline 10 & & & & & & & 35 & & & & & & \\
\hline 11 & & & & & & & 36 & & & & & & \\
\hline 12 & & & & & & & 37 & & & & & & \\
\hline 13 & & & & & & & 38 & & & & & & \\
\hline 14 & & & & & & & 39 & & & & & & \\
\hline 15 & & & & & & & 40 & & & & & & \\
\hline 16 & & & & & & & 41 & & & & & & \\
\hline 17 & & & & & & & 42 & & & & & & \\
\hline 18 & & & & & & & 43 & & & & & & \\
\hline 19 & & & & & & & 44 & & & & & & \\
\hline 20 & & & & & & & 45 & & & & & & \\
\hline 21 & & & & & & & 46 & & & & & & \\
\hline 22 & & & & & & & 47 & & & & & & \\
\hline 23 & & & & & & & 48 & & & & & & \\
\hline 24 & & & & & & & 49 & & & & & & \\
\hline 25 & & & & & & & 50 & & & & & & \\
\hline \multicolumn{3}{|c|}{ BSW $=$ Wyoming big sagebrush } & \multicolumn{4}{|c|}{ BSM $=$ Mountain Big Sagebrush } & \multicolumn{3}{|c|}{ BSB = Basin Big Sagebrush } & \multicolumn{4}{|c|}{$\mathbf{L S}=$ Low Sagebrush } \\
\hline \multicolumn{3}{|c|}{ Hits___ , \% _ , Ht. ${ }^{*}$} & \multicolumn{4}{|c|}{ Hits___, $\% \ldots$} & \multicolumn{3}{|c|}{ Hits___ , \% _ _,Ht. ${ }^{*}$} & \multicolumn{4}{|c|}{ Hits___, $\% \ldots$} \\
\hline \multicolumn{3}{|c|}{$\mathbf{P G}=$ Perennial Grass } & \multicolumn{4}{|c|}{ AG $=$ Annual Grass } & \multicolumn{3}{|c|}{$\mathbf{P F}=$ Perennial Forb } & \multicolumn{4}{|c|}{$\mathbf{A F}=$ Annual Forb } \\
\hline Hits & - & t. ${ }^{*}$ & Hits &,$\%$ & & & Hits & $\%$ & Ht.* & $\mathrm{Hi}$ &,$\%$ & & \\
\hline
\end{tabular}

* Average height recorded here. 
Site Forb Abundance Form for Sage Grouse Evaluations

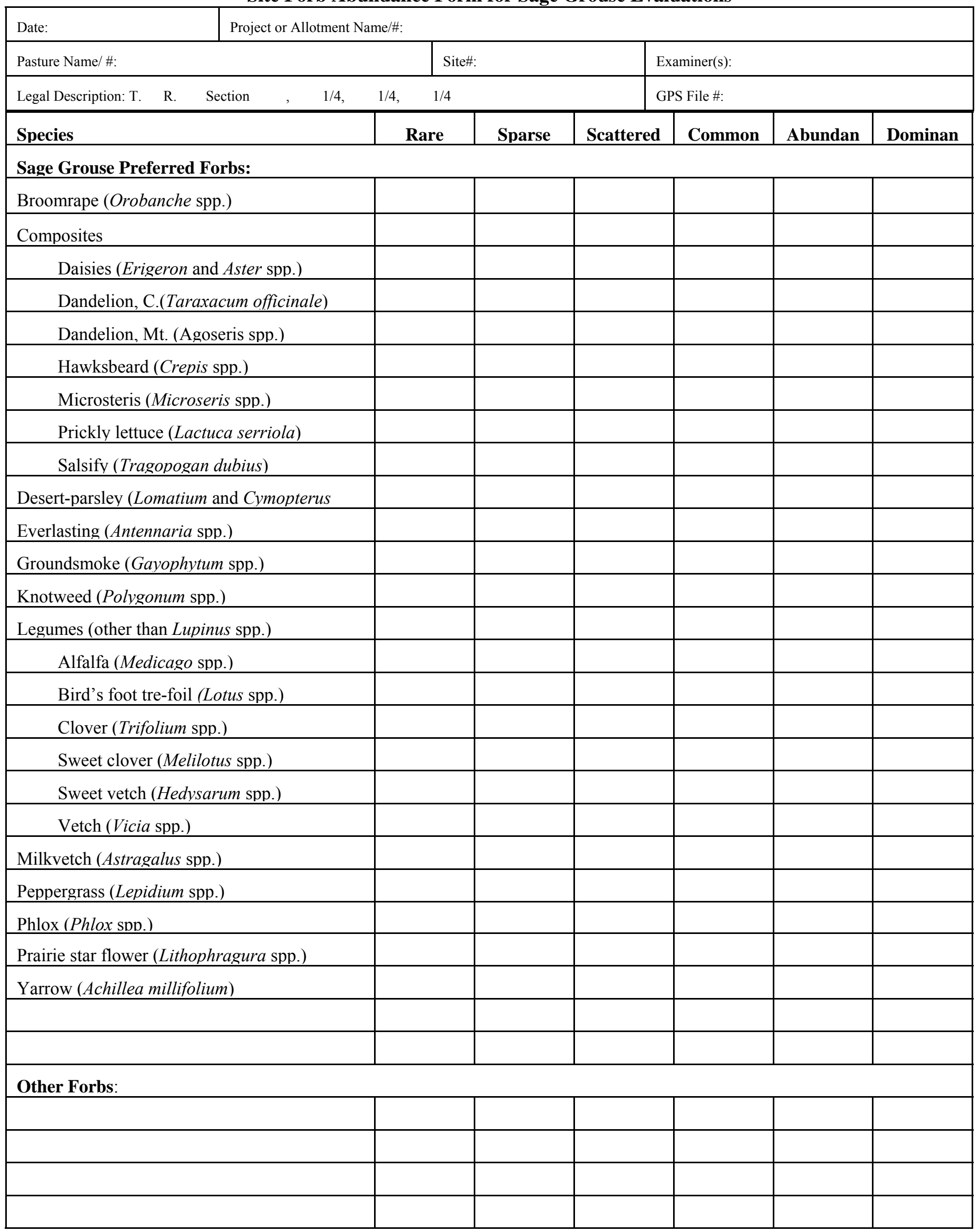




\section{Directions:}

1. Walk around an area generally the size of a 100-foot radius circle and observe the relative abundance of forbs based on the following ratings:

$\begin{array}{ll}\text { Rare: } & \text { Less than } 5 \text { plants } \\ \text { Sparse: } & 5-25 \text { plants } \\ \text { Scattered: } & 26-50 \text { plants } \\ \text { Common: } & 51-100 \text { plants } \\ \text { Abundant: } & +100 \text { plants } \\ \text { Dominant: } & \text { Very few other species present }\end{array}$

2. Check the appropriate abundance class on the form for the appropriate species.

2. Besides sage grouse preferred forbs, make particular note of noxious weed abundance. 
Sage Grouse Habitat Summary Evaluation Sheet

\begin{tabular}{|c|c|c|c|c|c|c|c|}
\hline \multicolumn{3}{|l|}{ Date: } & \multicolumn{5}{|c|}{ Project or Allotment Name/\#: } \\
\hline \multicolumn{8}{|c|}{ Project Description: } \\
\hline \multicolumn{3}{|l|}{ Recorder: } & \multicolumn{2}{|l|}{ FO: } & \multicolumn{3}{|l|}{$5^{\text {th }}$ HUC \#: } \\
\hline $\begin{array}{c}\text { Habitat Use } \\
\text { Period }\end{array}$ & $\begin{array}{c}\text { Pasture } \\
\text { / Site } \\
\text { No. }\end{array}$ & $\begin{array}{l}\text { Cover } \\
\text { Type }\end{array}$ & $\begin{array}{l}\text { Dominant } \\
\text { Species }\end{array}$ & $\begin{array}{l}\text { Ecological } \\
\text { Site }\end{array}$ & $\begin{array}{c}\text { Habitat } \\
\text { Evaluation } \\
\text { Results }\end{array}$ & $\begin{array}{c}\text { Site } \\
\text { Potential } \\
\text { Limiting? } \\
\text { (Y/N) }\end{array}$ & $\begin{array}{c}\text { Estimated } \\
\% \text { Pasture } \\
\text { or Project } \\
\text { Area }\end{array}$ \\
\hline & & & & & & & \\
\hline & & & & & & & \\
\hline & & & & & & & \\
\hline & & & & & & & \\
\hline & & & & & & & \\
\hline & & & & & & & \\
\hline & & & & & & & \\
\hline & & & & & & & \\
\hline & & & & & & & \\
\hline & & & & & & & \\
\hline & & & & & & & \\
\hline & & & & & & & \\
\hline & & & & & & & \\
\hline & & & & & & & \\
\hline & & & & & & & \\
\hline
\end{tabular}

Directions:

Summarize information from the field worksheets using this form.

Date: Date this form was filled out.

Project or Allotment Name: Identify project or allotment being evaluated.

Watershed ( $5^{\text {th }}$ HUC): Identify the watershed(s) that the project is in.

Project Description: Describe the project (e.g., S\&G evaluation, prescribed fire project; restoration project, land exchange, etc.).

Habitat Use Period: Use one of the following: Breeding (B), Brood-rearing (BR), Wintering (W).

Pasture/Site No.: Should correspond with Field Worksheet Pasture and/or Site Numbers.

Cover Type: Use one of the following or other unique descriptor: Sagebrush (SG), Perennial Grassland native (PGN), Perrenial Grassland - Seeded Non-native (PGS), Annual Grassland (AG), Annual Grassland with Sagebrush Cover (AGSG), Juniper (J), Riparian (R), Wet Meadow (WM), Lakebed (LB), Spring (SP). Should correspond to habitat type on Field Worksheet. 
Dominant Species: List the primary shrub and/or understory grass species. Intended for upland areas. Optional for brood-rearing habitats. Use species codes.

Ecological Site: Use appropriate name of ecological site descriptor from site guidesor soil surveys (upland sites only).

Habitat Evaluation Results: Transfer site evaluation summary from Field Worksheets here: Suitable (S), Marginal (M) or Unsuitable (US).

Site Potential Limiting ? (Y/N): Indicate here if site potential limits achieving suitable habitat objectives. Response needed for all sites identified as marginal or unsuitable habitats.

Estimated \% of Pasture or Project Area: Estimate based on available information. 


\section{APPENDIX C.}

\section{Adaptive Harvest Strategy}

The following Adaptive Harvest Strategy information was compiled by Fish, Wildlife and Parks and will be presented to the FWP Commission for consideration and adoption.

Harvest is typically regulated by season length and bag limit. Unless drastically reduced to a few days, season length does not have the same effect on harvest as changing the bag limit. Check station data for FWP regions 5, 6 and 7 were reviewed for the years 19611990 to determine 1) the total number of sage grouse checked and, 2) the number of hunters who took a limit. For each hunter who took a limit, the bag was reduced by one bird to see what effect that would have on the total harvest. Reducing the bag limit from four to three birds would have reduced the kill by approximately 10 percent, Table C-1. Reducing the bag limit from three to two would have reduced the kill by approximately 19 $\%$, Table $\mathrm{C}-2$. One of the criteria in adaptive harvest management is to make a change in bag limits that is great enough to be measurable in the harvest. A conservative and standard season with a bag limit of two and four birds respectively could be expected to affect the harvest by approximately 29 percent, which should be a measurable difference.

Several factors affect the size of the fall bird population and the subsequent harvest. Most factors influencing productivity are not readily quantified until late in the year. Lek surveys, which are completed by April, give the earliest indication of what can be expected in the fall harvest. During 1981-2003 the statewide average male attendance on leks ranged from 17.1 to 36.6 males with an average and median of 26.7 and 25.4 males/lek, respectively. Using 27 males/lek as the break point, male attendance $\leq 27$ would trigger a conservative bag limit and $\geq 27.1$ would trigger a standard season (Table C-3). Although a few years with low lek counts have a high harvest and vise versa, the majority of time lek counts give a reasonable indication of fall harvests. 
Table C-1. Sage grouse check station results for years with a four bird limit.

\begin{tabular}{|c|c|c|c|c|c|c|c|c|}
\hline \multirow{2}{*}{ Year } & \multicolumn{2}{|c|}{ Region 5} & \multicolumn{2}{|c|}{ Region 6} & \multicolumn{2}{|c|}{ Region 7} & \multicolumn{2}{|c|}{ Region $5,6, \& 7$} \\
\hline & \# Sage Gr & \# Limits & \# Sage Gr & \# Limits & \# Sage Gr & \# Limits & \# Sage Gr & \# Limits \\
\hline 1963 & 262 & 22 & 167 & 23 & & & 429 & 45 \\
\hline 1964 & 600 & 33 & 251 & 19 & & & 851 & 52 \\
\hline 1965 & 312 & 22 & & & & & 312 & 22 \\
\hline 1966 & 245 & 12 & 302 & 32 & & & 547 & 44 \\
\hline 1967 & 124 & 10 & 125 & 10 & 24 & 1 & 273 & 21 \\
\hline 1968 & 185 & 23 & 93 & 12 & 64 & 7 & 342 & 42 \\
\hline 1969 & 242 & 30 & 105 & 9 & 92 & 8 & 439 & 47 \\
\hline 1970 & 248 & 28 & 24 & 1 & 12 & 0 & 284 & 29 \\
\hline 1971 & 347 & 39 & 229 & 42 & 40 & 5 & 616 & 86 \\
\hline 1972 & 268 & 32 & 102 & 15 & & & 370 & 47 \\
\hline 1973 & 393 & 42 & 232 & 26 & & & 625 & 68 \\
\hline 1974 & 430 & 44 & & & & & 430 & 44 \\
\hline 1975 & 523 & 61 & 71 & 6 & & & 594 & 67 \\
\hline 1980 & 379 & 24 & & & & & 379 & 24 \\
\hline 1983 & 529 & 51 & & & & & 529 & 51 \\
\hline 1984 & 245 & 15 & & & & & 245 & 15 \\
\hline 1988 & 49 & 0 & & & & & 49 & 0 \\
\hline 1989 & 130 & 13 & & & & & 130 & 13 \\
\hline 1990 & 127 & 18 & & & & & 127 & 18 \\
\hline Total & 5638 & 519 & 1701 & 195 & 232 & 21 & 7571 & 735 \\
\hline
\end{tabular}

Table C-2. Sage grouse check station results for years with a three bird limit.

\begin{tabular}{ccccccc}
\hline \hline \multirow{2}{*}{ Year } & \multicolumn{2}{c}{ Region 5 } & \multicolumn{2}{c}{ Region 6 } & \multicolumn{2}{c}{ Regions 5 \& 6 } \\
\cline { 2 - 7 } & \# Sage Gr & \# Limits & \# Sage Gr & \# Limits & \# Sage Gr & \# Limits \\
\hline \hline 1962 & 65 & 13 & 169 & 33 & 234 & 46 \\
1963 & 221 & 41 & & & 221 & 41 \\
1965 & & & 127 & 30 & 127 & 30 \\
1974 & & & 53 & 9 & 53 & 9 \\
1976 & 454 & 99 & 12 & 0 & 466 & 99 \\
1977 & 293 & 52 & 60 & 5 & 353 & 57 \\
1978 & 341 & 65 & 68 & 12 & 409 & 77 \\
1979 & 340 & 69 & & & 340 & 69 \\
1981 & 272 & 49 & & & 272 & 49 \\
1982 & 327 & 68 & & & 327 & 68 \\
1985 & 56 & 6 & & & 56 & 6 \\
1986 & 121 & 17 & & & 121 & 17 \\
1987 & 105 & 22 & & & 105 & 22 \\
\hline \hline Total & 2595 & 501 & 489 & 89 & 3084 & 590 \\
\hline \hline
\end{tabular}


Table C-3. Sage grouse harvest as it relates to sage grouse male lek attendance, 1981-2001.

\begin{tabular}{cccc}
\hline \hline Year & Males/Lek & Harvest & Season \\
\hline 1994 & 17.0 & 10989 & Conservative \\
1995 & 18.8 & 8955 & Conservative \\
1993 & 19.7 & 7716 & Conservative \\
1986 & 20.0 & 12686 & Conservative \\
1996 & 20.2 & 9513 & Conservative \\
1997 & 20.7 & 7216 & Conservative \\
1985 & 21.0 & 10791 & Conservative \\
1992 & 22.7 & 12026 & Conservative \\
1998 & 24.0 & 7945 & Conservative \\
1999 & 24.8 & 9016 & Conservative \\
1987 & 25.4 & 28578 & Conservative \\
1981 & & & Standard \\
1990 & 29.1 & 26680 & Standard \\
1989 & 29.8 & 20456 & Standard \\
2001 & 30.7 & 16178 & Standard \\
2000 & 31.9 & 4525 & Standard \\
1982 & 31.9 & 7806 & Standard \\
1991 & 33.2 & 22328 & Standard \\
1988 & 33.4 & 16944 & Standard \\
1983 & 34.6 & 18878 & Standard \\
1984 & 35.2 & 42870 & Standard \\
\hline \hline
\end{tabular}




\section{APPENDIX D.}

\section{LEK MONITORING TOOLS}

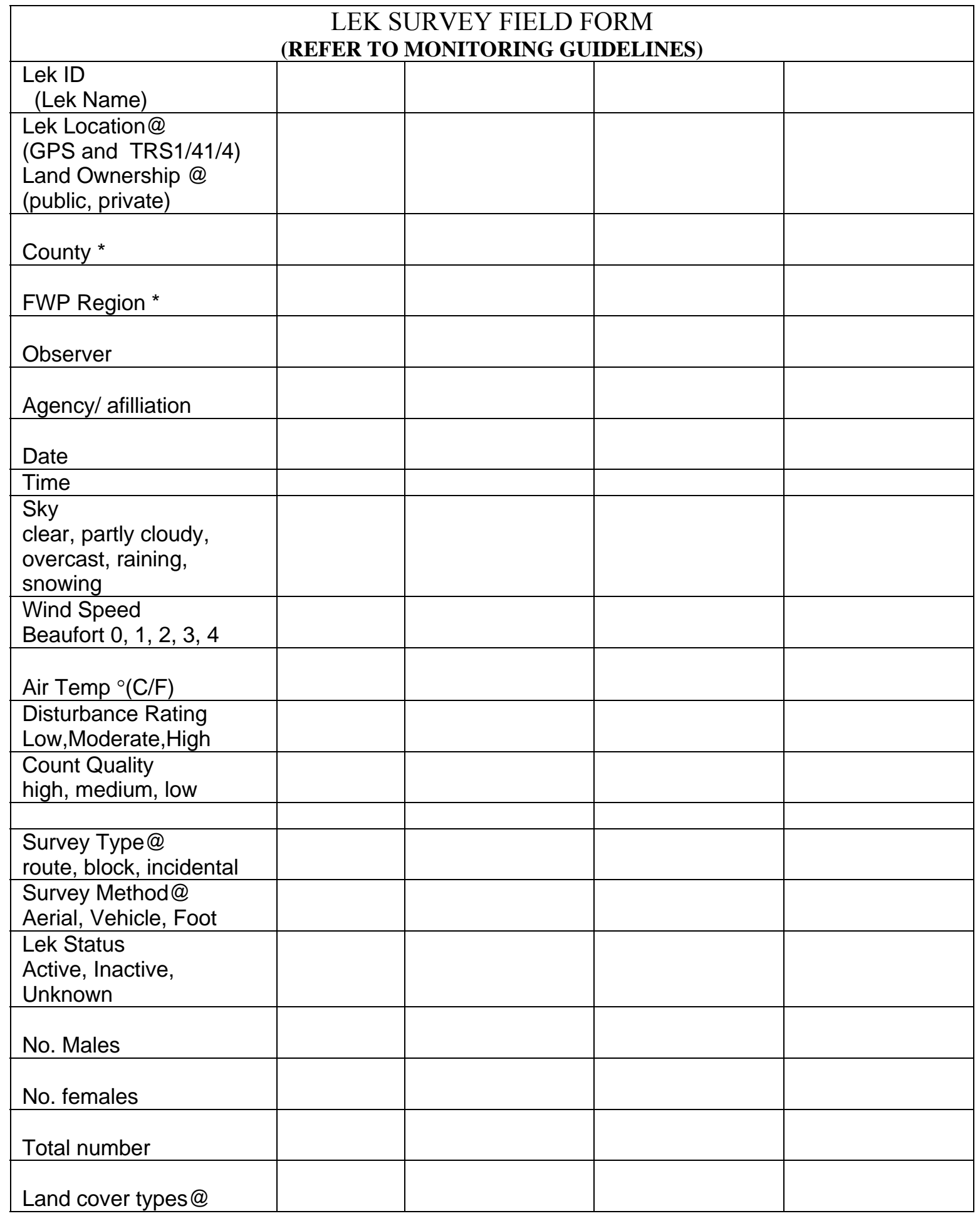




\begin{tabular}{|l|l|l|l|l|}
\hline Land Cover Status@ & & & & \\
\hline Residual Cover Status & & & & \\
\hline Site Photograph? & & & & \\
\hline
\end{tabular}

\begin{tabular}{|l|l|l|l|l|}
\hline Comments: & & & & \\
& & & & \\
\hline $\begin{array}{l}\text { * include if not part } \\
\text { of Lek ID } \\
\text { @optional if same as } \\
\text { previous year }\end{array}$ & & & & \\
\hline
\end{tabular}




\section{APPENDIX E.}

\section{Summary of Public Comments with Responses}

\section{TABLE OF CONTENTS}

Headings

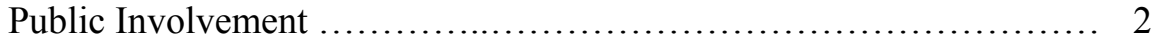

Responses to Public Comments................................... 2

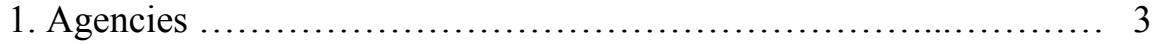

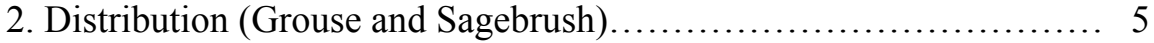

3. Education................................................... 6

4. Endangered Species Act......................................... 7

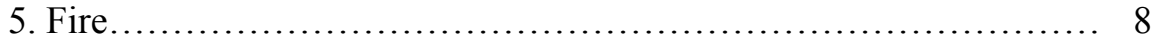

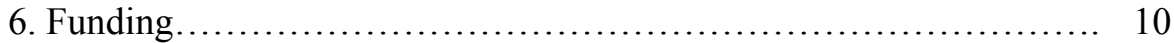

7. General Comments.......................................... 10

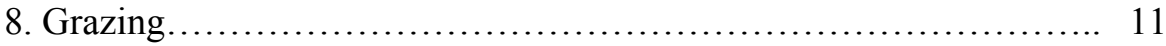

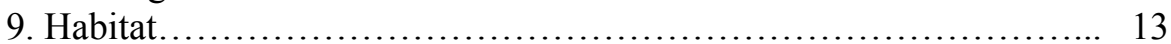

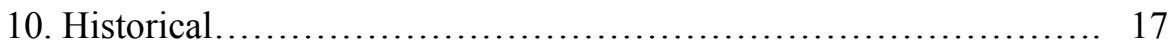

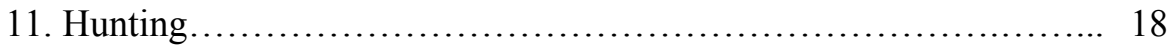

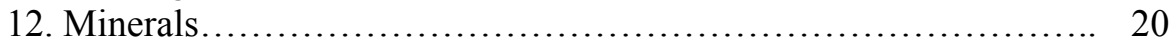

13. Monitoring ................................................... 21

14. Noxious Weeds............................................... 21

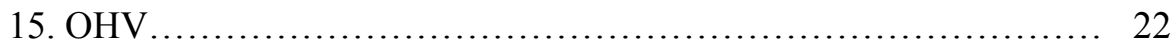

16. Other Species................................................. 22

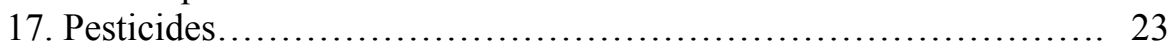

18. Plan Document............................................... 23

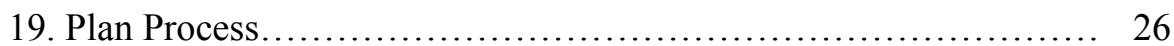

20. Population.................................................... 27

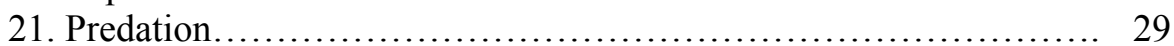

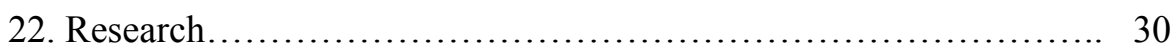

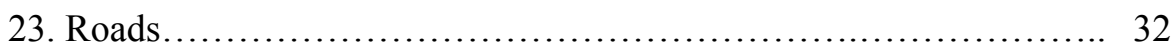

24. Structures (Power Lines and Fences) ......................... 33

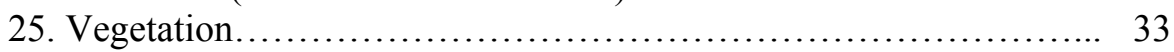

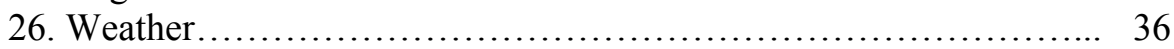

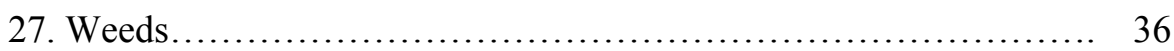

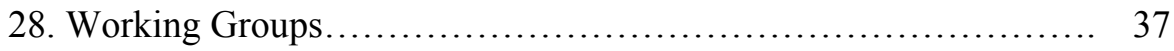




\section{PUBLIC INVOLVEMENT}

The Draft Plan was developed over a 2-year period by the Montana Sage Grouse Work Group, which included a very diverse spectrum of Montana stakeholders. Each Work Group meeting (approx. 15) was open to the public and was held at various locations across the state. The Draft Plan was made available for public review December 1, 2002 for a period of 6 weeks.

During early December 2002, public meetings were held at the following locations for the purposes of acquainting the public to the Draft Plan and accepting comments:

$\begin{array}{ll}\text { Glasgow } & \text { December 3, 2002 } \\ \text { Miles City } & \text { December 4, 2002 } \\ \text { Lewistown } & \text { December 4, 2002 } \\ \text { Billings } & \text { December 5, 2002 } \\ \text { Great Falls } & \text { December 9, 2002 } \\ \text { Dillon } & \text { December 10, 2002 } \\ \text { Butte } & \text { December 11, 2002 }\end{array}$

A total of 102 comments were received during the public comment period. From these comments, 572 individual points were recorded. These were condensed into 136 points and organized by issue categories.

Commenters included the following:

$$
\begin{aligned}
& \text { Hunters }-12 \text { comments } \\
& \text { Landowners }-29 \text { comments } \\
& \text { General }-47 \text { comments } \\
& \text { Agencies }-3 \text { comments } \\
& \text { NGOs* }-11 \text { comments }
\end{aligned}
$$

* Non-Governmental Organizations including: One grazing district; 2 grazing associations; Central MT Resource Advisory Council; SW MT Stockman's Association; Montana Wildlife Federation; National Wildlife Federation; Wildlife Management Institute; East Pioneer Experimental Stewardship Program; Intermountain Section - Society of Range Management; Gallatin Wildlife Association

Generally speaking, the draft scoping document appeared to address most or all substantive issues raised by public comments. That is, sage grouse conservation issues described in the Draft Plan represented issues identified in the public comments. Public comments covered a full spectrum of perspectives on sage grouse and habitat conservation issues.

\section{RESPONSES TO PUBLIC COMMENTS}

In the following sections, representative public comments are arranged by subject matter. Our responses, in italics, are written immediately after a public comment or grouping of public comments. Double slashes (//) are used to separate grouped comments. Cited literature can be found in the Final Draft Plan's Literature Citation section. 


\section{Agencies}

Land management agencies lack strong ties and commitments to the Plan. Funding and planning priorities need to be set reflecting sage grouse priorities. Resource activities need to be managed so as to minimize impacts on sage grouse. Federal agencies need to identify which Actions or Guidelines they intend on following. // The plan should expressly state that to the extent consistent with its authorities, responsibilities, and budgetary constraints and to the maximum extent practicable the agencies agree to: 1) support the Plans conservation goal and achievement of the habitat and population objectives; 2) implement, where appropriate, conservation actions identified in the Plan; 3) utilize the Plan's habitat assessment framework for sub-basin reviews, watershed analyses, standards and guides evaluations, Land Use Plan evaluations, and any proposed projects that might affect sage grouse habitat; 4)utilize the Plan's protocol for monitoring leks; 5) manage sage grouse habitat and implement other actions to conserve sage grouse in a manner consistent with the Plan or explain the reasons for any deviations from the Plan.

At this early stage, BLM is agreeing to the Plan in principle and is willing to cooperate in the implementation of the Plan. The agency will continue to collaborate with the state workgroup and become active participants in local and regional implementation efforts. Interagency Agreements that outline responsibilities and commitments may be developed for cooperating agencies in the future. The National Environmental Policy Act requires that any authorized federal action or new management objectives include public involvement and be analyzed and authorized through a decision document.

The Director of BLM has recently assembled an interdisciplinary team to establish a comprehensive Sage-grouse Habitat Conservation Strategy for BLM-administered lands. State- specific strategies for BLM will be developed under a national framework, recognizing the need for consistency with State-led conservation planning efforts. The primary purpose of the BLM sage-grouse strategy is to focus attention, resources and actions at reducing potential threats on BLM public land. BLM efforts are intended to compliment State-led planning efforts, identify necessary key actions and set timelines for both short and long term actions. The public will have the opportunity to provide input and participate in developing state-specific BLM Plans.

We have added a signature page at the end of the Plan that ties together the commitments of the involved agencies to the Plan, as per their individual missions and responsibilities.

Significant sage grouse areas should be designated as Areas of Critical Concern. When will BLM designate sage grouse as a sensitive species?

$B L M$ regulations (43 CFR part 1610) define an ACEC as an area "within the public lands where special management attention is required (when such areas are developed or used or where no development is required) to protect and prevent irreparable damage to important historic, cultural, or scenic values, fish and wildlife resources, or other natural systems or processes, or to protect life and safety from natural hazards."

To be designated as an ACEC, an area must meet the relevance and importance criteria listed in BLM Manual 1613 (1988) and require special management to protect and prevent irreparable damage to relevant and important resource values. Areas may be nominated at any time but the ACEC designation is an administrative designation that is accomplished through the land use planning process.

BLM is currently revising the sensitive species list for BLM Montana/Dakotas. Sage-grouse will be recommended as a sensitive species for the revised list. The State Director will formally adopt the new list when the review is completed.

RAC endorses BLM's statement in Section II, Pg 10-11 in their entirety: RAC request 3 sentences be added: "Local working groups shall have input into decision making to adjust plan guidelines in accordance with the area's environment." "Sage grouse recovery is dependent on community-based 
conservation; it is impossible to write one set of guidelines that are applicable to the widely varying conditions within Montana" "The impact of climate, drought and predators shall be considered"

Working groups will work within the guidelines of the Plan. Purposefully, the guidelines have been broadly written so they can be adapted to local conditions. Section VI provides direction to working groups by listing broad goals, describing related issues, and prescribing one or more conservation actions. These actions are intended to provide direction and may need to be modified to fit local circumstances.

NRCS is absent from the Plan. They should be a critical partner, brokering habitat implementation with private landowners.

An agency commitment section by NRCS has been added to the Plan.

Will FWP complete an EIS for sage grouse?

After the Final Draft Plan has been adopted by the State Workgroup A MEPA Environmental Assessment will be developed which assesses the Plan and alternatives as to impacts on the physical and human environments. Based on the environmental assessment, an evaluation as to the significance of individual and cumulative impacts will be made to determine if significance criteria exist to require an Environmental Impact Statement.

While DFWP maintains a dual role (Section II, p. 1) that of stewards of Montana's wildlife and habitats, there is no statutory authority for DFWP to manage habitat. The Plan is aimed entirely at habitat management through the eyes of wildlife biologists. Instead, the issues of predation, disease, and hunting, which are under the authority of DFWP, were largely dismissed.

The plan was developed through a collaborative process involving many interests and substantial public input. Twelve major issues of concern are described in the Plan with a list of specific conservation strategies related to each issue. Also, in response to public comments on the Draft Plan and through further work by the State Sage Grouse Work Group, additions have been included in the Final Draft Plan that help clarify the impacts of issues described in this comment.

BLM and FWP have an MOU which was put together after Winnett sage grouse study which gave 2 years lead time to FWP prior to any sage brush manipulations. BLM is in violation of this agreement.

Members of the State Sage Grouse Work Group looked into this and were not able to find an MOU on file.

Re: Section II, Pg 5. The "Fundamentals for Standards for Rangeland Health" discusses making "significant progress". What does that mean? How is it measured? Who measures it?

43 CFR 4100, effective August 21, 1995, established the "Fundamentals for Standards for Rangeland Health". Regional standards and guidelines were adopted by BLM Montana/Dakotas in May 1997. Standards are defined as statements of physical and biological "condition" or degree of "function" required for healthy sustainable rangelands. 43 CFR 4180.1 requires all uses of public lands achieve or make significant progress towards the standards.

Interdisciplinary teams, in consultation with permittees and interested parties, use historical information, monitoring and trend data, and all other available information to assess the health of landscapes and determine if standards are being met. When a situation occurs where standards are not 
being met and the condition or trend is not showing signs of improvement, management adjustments will be made. "Significant progress" is not defined and must be determined by the field manager.

\section{Distribution (Grouse and Sagebrush)}

27 million acres of sagebrush seems very high. Is that figure potential or current habitat? Rather than protecting all sagebrush, the Plan should only consider habitats used by sage grouse. Start with 2-mile radius around leks. Payne estimated 18 million acres of sagebrush statewide.

Section I page 4 of the Plan states: "This estimate of potentially occupied sage grouse habitat will be refined as methods are improved for classifying and separating sagebrush vegetation communities, especially at canopy densities $<20$ percent, from native grassland habitat types." It is also important to note as stated in Section III page 1, that although sage grouse in Eastern Montana are considered non-migratory, their ability to "meet yearlong needs may require comparatively long seasonal movements between disjunct habitat patches." Because of this, it is difficult to fully define yearlong use of sagebrush-grassland habitats, especially along the periphery of sage grouse distribution. With regard to the 2-mile radius, Section VII page 4 states: "delineating nesting habitat using the 2-mile radius around an active lek must be applied with caution. This delineation may help define areas of management emphasis, but most remaining large tracts of sagebrush likely provide habitat."

The 18 million acre-figure, referenced with Payne's publication (Vegetative Rangeland Types in Montana, Montana Ag. Exp. Stn. Bulletin 671, 1973), does not include portions of the Northern Grassland or Foothill Grassland vegetative rangeland types, identified by Payne. Although Payne does not emphasize sagebrush in these areas, significant portions of these types are known to support sagebrush and sage grouse. We believe this likely represents a large part of the discrepancy. However, as stated in the Plan, our acreage figure of 27 million acres is an estimate and will continue to be refined.

The Plan's map shows farmland as sage grouse habitat. The Plan should limit its scope to where sage grouse occur. Re: Section I, Pg 3. Managers shouldn't have to also restore sagebrush habitats for distribution and connectivity between patches, where grouse don't occur.

As stated in Section I page 1, "This estimate was based on areas (polygons) mapped by state and federal biologists and delineated using land cover types, including sagebrush classes, from the Montana GAP Analysis." At present, the GAP analysis only identifies sagebrush steppe of relatively high canopy coverage ( $\geq 20$ percent). The hand-drawn polygons were a rough extrapolation of GAP analysis information combined with known sage grouse and sagebrush distribution. Vegetation classes representing cropland, irrigated cropland, urban areas, etc. were removed for estimating sage grouse habitat but were not distinguished on the graphics due to graphic size limitations. As part of this Plan, a refined method of defining sage grouse habitat will be developed (Section I page 4).

Re: Section I, Pg 1. It is not possible to maintain the distribution and integrity of communities as they currently exist. This snapshot in time may not be the best composition for maintaining sage grouse populations. That would mean no development within sagebrush grasslands nor conversion of areas to support sagebrush communities.

We believe sagebrush distribution is a result of the natural potential for an area to grow sagebrush. Mueggler and Stewart (1980) researched native vegetation in western Montana and recognized six distinct habitat types in which sagebrush taxa are dominants. Hansen et al. (1995) described riparian habitats across Montana and recognized 2 silver sagebrush habitat types associated with riparian areas in Montana. Peterson (1995) and Harrington (2002) reported numerous historical accounts of sagebrush in Montana from the early 1800's forward which suggest sagebrush distribution 
has changed little over the past 2 centuries, except for losses due to plowing, chemical treatment, fire, and agricultural conversion. We agree that in some areas, sagebrush density or canopy coverage has been affected by management activities, such as overgrazing. Historical and research evidence suggests, however, that big sagebrush is a naturally occurring species in its present distribution (Daubenmire 1970, Beetle and Johnson 1982, Welch in preparation).

No net loss of sagebrush habitat is an appropriate goal. Habitat loss is considered to be the primary factor associated with declining sage grouse abundance across their range (Connelly and Braun 1997, Schroeder et al. 2000). Conserving Montana's remaining sage grouse habitat base is a necessary part of long-term sage grouse conservation.

Re: Section III, Pg 4. The statement that more than $70 \%$ of the sagebrush rangeland has been converted to cropland is not valid in MT. Even with the cultivation in NE MT, we believe there is more sagebrush than when Lewis and Clark traveled through the country.

The statement about 70\% habitat conversion in some states was intended to show the level of impact conversion of sagebrush habitat to cropland has had on sage grouse habitat across their range. Even in some parts of Montana, conversion of rangeland to cropland has affected sage grouse abundance and distribution (Section III page 4). These observations point out the importance of conserving remaining sage grouse habitat.

Re: Section IV, Pg 4. Mtn big sagebrush dominates the upper elevations of the SW segment of the intermountain valley ecotype but WY big sagebrush is the common subspecies of the major river system valley bottoms and lower foothills.

We agree with this general statement. Sagebrush taxa are distributed in patterns generally controlled by moisture-elevation gradients and soil properties. For instance, basin big sagebrush also commonly dominates deep soil areas in SW Montana.

Re: Section IV, Pg 4, Ecotype Descriptions. Whereas mountain big sagebrush is a major component on most summer habitats, the winter and lek habitats are dominated by Wyoming big sagebrush, with substantial compositions area wide of at least three other sagebrushes (tall three-tip, Basin big sagebrush, and early low sagebrush). This ecotype would be better described as Mountain Foothills mixed sagebrush.

Around Dillon, yearlong sage grouse habitats are located in sage communities composed of a combination of sage taxa, including mountain big sage (Artemesia tridentata spp. vaseyana), Wyoming big sage (A.t. spp. wyomingensis), basin big sage (A.t.spp. tridentata), three-tip sage (A. tripartita), silver sage (A. cana), and black sage (A. nova) (G. Hammond and M. Frisina personal communication). We agree this ecotype may be better described as Mountain Foothills mixed sagebrush. This change has been included in the Plan.

\section{Education}

A full color brochure such as that used by Nevada to provide information to the general public may attract more attention to the issue and bring it to the forefront.

Section VI page 18 lists a number of conservation strategies for public outreach and education. A brochure is one of the strategies. 


\section{Endangered Species Act}

The Plan needs to contain proactive language to ensure the end product meets requirements in the framework of the USFWS's Policy which is "the certainty that the conservation effort will be implemented" and "the certainty that the conservation effort will be effective." Certain PECE criteria have not been met in the Plan:

- PECE Criteria A1. The staffing or funding level for Plan implementation has not been identified for FWP or other parties.

- PECE Criteria A2. The legal procedure required for implementing the effort has not been described for all parties.

- PECE Criteria A3. Landowner permission and other authorizations or a "high level of certainty" for landowner permission or other authorizations has not been described.

- PECE Criteria A4. The level of voluntary participation necessary to implement the conservation effort has not been identified.

- PECE Criteria A5. Regulatory mechanisms necessary to implement the conservation effort have not been described, so it is unclear whether all are in place.

- PECE Criteria A6. The funding required to implement the plan is not described, nor is a "high level of certainty" that the necessary funding will be provided described.

- PECE Criteria A7. Other than the "50 year no net loss" habitat goal, and a schedule for convening working groups, no schedule or completion dates for the conservation effort is provided.

- PECE Criteria A8. We realize that parties will formally approve the plan in its final form.

- PECE Criteria B1. I maintain that the threats posed by livestock grazing and coal bed methane development and others (utility corridors, roads, fences, springhead capture, fire, weeds, West Nile Virus, other diseases, etc.) have not been adequately described.

- PECE Criteria B2.Explicit objectives need to be generated for habitat conservation (acreage, condition, location, etc.).

- PECE Criteria B3. The steps needed to implement the conservation effort have not been fully identified.

- PECE Criteria B4. Scientifically valid parameters for demonstrating achievement of habitat objectives, or standards by which progress towards habitat objectives will be measured, have not been identified.

- PECE Criteria B5. Provisions for monitoring and reporting progress in implementing habitat objectives have not been provided.

- PECE Criteria B6. No adaptive management principles have been proposed for meeting habitat objectives, or population objectives where harvest is not a factor. //

Other than the "50-year no net loss", no schedule of completion dates for the conservation effort is provided. This is too long and will be forgotten. The Plan needs to adopt a clear implementation schedule with a timeline and milestones, budget estimates for carrying out its key initial elements, and identification of funding sources to secure identified resources. Each objective needs to be subject to evaluation by time period or statistic.

The PECE Criteria provide a basis for the USFWS to measure the strengths of a species management Plan when making a determination for listing under the Endangered Species Act. The Management Plan and Conservation Strategies for Sage Grouse in Montana is the product of a collaborative effort between a number of organizations and agencies committed to sage grouse conservation in Montana. Developing the Plan represents a significant "stepping up" for sage grouse conservation in Montana. All of the key interests necessary for accomplishing effective sage grouse conservation have been actively involved in the process. Individual agency commitments (Section II) and 
strategies developed to effect sage grouse conservation (Section VI) based on a common scientific-based understanding of the sage grouse's status and needs (Sections III-IV) are described in the Plan. Because Montana supports a relatively intact habitat, our primary emphasis is maintaining and enhancing existing sagebrush-grasslands. FWP has provided a clear commitment with timelines to purchase longterm sagebrush protection on private lands (Section II). The Plan includes a timeline for developing local working groups for applying conservation strategies at a local level, led by a cooperatively-funded coordinator (Section VIII). The Plan is the start and continuation of ongoing sage grouse conservation in Montana. Montana Fish, Wildlife \& Parks and the Montana Sage Grouse Working Group will oversee and monitor sage grouse accomplishments and will provide a mechanism to adapt to improved understanding and changing conditions (Section VIII). We believe this is a solid conservation strategy with the backing of partners committed to the sage grouse's long-term viability in Montana.

Legal action should be taken to recoup the sportsman's costs associated with petitions to list sage grouse.

This comment is outside the scope of the Plan.

\section{Fire}

Re: Section V Pg 2 and Section VI Pg 2. Managing mesic mountain big sagebrush may require a mosaic of cool prescribed burning to open canopy and allow forbs to be more competitive. This may be necessary to keep the system sustainable and can result in no net loss. In mesic mountain big sage sites, varied aged stands are essential to maintaining a mature sagebrush community. // Re: Section V Pg. 2 and VI Pg 2-4. Under rangeland treatments, there are no citations concerning the effects of prescribed fire. Fire is a natural component of sagebrush ecosystems and sage grouse evolved to survive in sagebrush areas that have burned. To assert that fire in sagebrush communities is detrimental to sage grouse doesn't correspond to these facts. A properly functioning "climax" sage grouse habitat is not static. Fire is a natural component. Fire would be better dealt with by local working groups. // Re: Section III Pg 3 . Succulent forb distribution was based on annual precipitation, which we can do nothing about. Fire, however, greatly stimulates germination of forbs, especially when a dense canopy of sage brush is removed.

Although fire is a natural occurrence, that doesn't necessarily mean it is good for sage grouse. Two recent guiding documents on sage grouse conservation provide direction on the use of fire in sage grouse habitats. Connelly et al. (2000b) cautioned about the use of any treatments to manipulate sagebrush-grasslands until limiting vegetative factors have been clearly identified. If treatments are determined to be beneficial for addressing these limiting factors, they recommend only treating up to $20 \%$ of the breeding or winter habitat over the period of time it takes for sagebrush to recover. Wambolt et al. (2002) suggested burned areas may take from 40 to greater than 100 years of recovery time to provide habitat capable of supporting sage grouse. We suggest past burns in the vicinity of a proposed burn can be used to make this determination. Negative effects of fire can include loss of hiding and thermal cover, reduction in insect population, and avoidance by sage grouse (Connelly et al. 2000b, Wambolt et al. 2002).

As the comment suggests, fire has been used to try to increase forb production. Connelly et al. (2000b) reported on recent studies that had mixed success increasing forb production. They described burning in Wyoming big sage habitats as having mostly negative effects on brood rearing habitats whereas burning in mountain big sage habitats had mixed results and requires further investigation. Wambolt et al. (2002) made two points. First, no research has identified the pounds-per-acre of forbs sage grouse require. It can therefore be difficult identifying forb abundance as a limiting factor. Second, sagebrush canopy cover has not been clearly shown to affect forb production. We know of no research 
that documents prescribed burning actually benefiting sage grouse and resulting in improved populations. There are numerous studies, however, that show the detrimental aspects of sage loss to sage grouse.

Controlled burns may help reduce the risk of a major wildfire that would cause much more damage to habitat.

As stated earlier, fire in general can negatively impact sage grouse habitat. Fire suppression appears to be the best method for conserving sagebrush habitats.

FWP agreed to change the language in two conservation actions before the draft was released. Changes were not completed. They were: 1) Section VI, Pg 3,\#2. Change to: Develop local or regional guidelines (e.g. Beaverhead-Deerlodge Forest FWP guidelines), or consider the following guidelines if fire is used as a tool elsewhere (rest remains the same). 2) Section VI, Pg 3, \#4. Change to: Consider both mechanical treatments and prescribed fire if actions are required to remove conifers that encroach on sage grouse habitat. Heavy fuels, ecological considerations and availability of forest habitats should influence the preferred method. // Re: Section VI, Pg 29. We recommend options for treatment of conifer encroachment be placed in priority by the way they are listed in the Conservation Actions. Fire should be the first treatment option, it is the natural method.

Changes related to comment \#1) have been included in the Plan. With regard to controlling conifer encroachment, the Plan describes prescribed fire as a secondary tool where mechanical methods are not possible. Prescribed fire results in removal of sagebrush stands as well as encroached conifers. Although fire is natural, it isn't necessarily good for sage grouse (Connelly et al. 2000b, Wambolt et al. 2002). Prescribed fires that remove sagebrush stands can result in a long-term loss of sage grouse habitat (Section V page 2). Mechanical methods of removing conifers maintain sagebrush and are, therefore, considered less disruptive to sage grouse and other species that rely on sagebrush for cover and food. As per this request, we have changed the wording in Section VI, Pg3, \#4 in a manner that considers both treatment options with the preferred method being based on sage grouse habitat needs, ecological considerations, and availability of forest habitats.

Re: Section VI, Pg 1. What is meant by managing the post-burn site properly? Without proper definitions, these could lead to future conflicts.

"Managing post burn sites properly" means that the agency will manage grazing, weeds, reseeding or other activities that potentially influence the outcome of rehabilitation or treatment in a manner that achieves the desired condition of the site. This has been added to the Plan.

Re: Section VI, Pg 3, 2d: use available literature (e.g., Fire Effects Information System, $\mathrm{http} / \mathrm{www} . f s . f e d . u s /$ database/feis/animals/bird/cent/index.html) to research the effects of fire on sagebrush species and communities.

The web site on sage grouse and fire includes much of the same research literature cited by the Plan, Connelly et al (2000b), and Wambolt et al. (2002). One case study is included in the web site. This study was completed in Oregon and reports effects of fire on forbs one year after a burn. The study shows immediate response by forbs compared with control sites, which agrees with other studies and is often times a result of nutrient releases caused by fire (Wambolt et al. 2002). Only one year of data on forb abundance was included, which may not be an accurate measure of the long-term effects of burning. When and where possible, we believe refereed research should provide the scientific basis for sage grouse conservation. 


\section{Funding}

I object to $50 \%$ of HB 526 funds being spent on sagebrush conservation. What about elk, deer, moose? This eliminates projects west of the divide.

Sage grouse habitats across Montana provide important food and cover for a host of other wildlife. There are many areas of overlap where habitats supporting sage grouse also provide key habitat for deer, elk, antelope and many other game and non-game species.

How much money have partners committed to sage grouse conservation? Why are hunters paying again?

It is difficult to accurately sum partner costs and commitments at this time. As future planning processes and projects are implemented, funding by individual partners will become more apparent. The Plan stresses habitat conservation, which is the key to long-term sage grouse conservation. Sagebrushgrasslands, which are important for sage grouse, are also important habitats for a variety of other wildlife species. This Plan continues the tradition of hunters proactively helping to conserve wildlife and their habitats.

Adequately funding habitat conservation is a must.

We agree. The Plan will help with funding by clearly describing what is needed to conserve sage grouse and by providing an opportunity for individual agencies to commit to appropriate aspects of the Plan. The work of developing the Plan and commitments and strategies described in the Plan has emphasized partnerships, which is a key to funding any conservation program.

Re: Section VII, Pg 9. How will recommended inventory work be funded?

Inventories of habitat and populations are accomplished with state and federal agency funding and partnerships. BLM has already initiated multiple scale assessments for watersheds and eco-regions across the west.

\section{General Comments}

There is no evidence in MT that sage grouse are endangered or threatened. This notion is based on false assumptions and loss of habitat in other states. Do the groups who file petitions understand the sage grouse status in MT?

We agree that sage grouse are not endangered or threatened in Montana. However, some of the petitions to have sage grouse listed under the endangered species act are range-wide. Therefore, Montana is included with the other affected states. Montana has, however, experienced habitat losses, primarily due to plowing. Fortunately, these losses are not as significant as those experienced in some other states (Introduction page 1). The purpose of the Plan is to provide for the long-term conservation of sage grouse in Montana, keeping the species from becoming threatened.

You need to consider the economic impacts of the Plan as written. Does this require an economic analysis? EIS? 
The final version of the Plan will be accompanied with an environmental assessment (EA) consistent with Montana Environmental Policy Act. The EA will evaluate the Plan's potential impacts as well as invite further public review. An evaluation of economic impacts would be included.

Will this Plan affect my private land? If listed, how will that affect my private land?

The Plan is a proactive measure to conserve Montana's sage grouse and to help keep the species from being listed as threatened or endangered under the Federal Endangered Species Act. The Plan states in the Introduction page 2 "This plan is not intended to exclude any uses or activities or infringe on legally defined private property rights; rather, it serves to provide solutions to problems and address issues that negatively affect sage grouse and degrade sagebrush community health." The Plan does support incentive-based conservation actions on private land as described in Section VI. However, if sage grouse were listed, the Federal Endangered Species Act would be more likely to directly affect uses of public and private land as well as federal assistance programs targeted for private land.

The Plan needs more information on West Nile Virus.

We have added additional information on West Nile Virus and its occurrence in radio-collared sage grouse in Montana to Sections III, V, and IX.

\section{Grazing}

Sagebrush is an increaser. If part of the plan would be to limit livestock grazing you would over time reduce the stand of sagebrush. Reducing grazing has reduced sagebrush habitat.

The Plan does not call for limiting or reducing livestock numbers. The sagebrush-grasslands of Montana have supported ungulate grazing and sage grouse for thousands of years. Livestock grazing is an important part of Montana's economy and has resulted in the maintenance of large expanses of sage grouse habitat (Section VI). The Plan supports managed grazing systems that ensure soils and vegetation are conserved while providing for the needs of sage grouse and other wildlife (Section VI page 7). We believe long-term conservation of sage grouse will ultimately result in long-term benefits for grazing by conserving rangelands that support sage grouse and livestock. Also, as pointed out earlier, a number of researchers and plant ecologists describe sagebrush as a native climax plant species with a distribution that has changed little over the past 200 years (Daubenmire 1970, Mueggler and Stewart 1980, Beetle and Johnson 1982, Hansen et al. 1995, Peterson 1995, Harrington 2002, Welch in preparation).

Re: Section VI, Pg 30. We disagree with Conservation Action to develop and implement grazing practices that will influence sagebrush growth. This implies poor range management.

The goal statement qualifies this Conservation Action by stating, “...that meet seasonal needs of sage grouse while contributing to overall community health." We are not proposing to degrade rangeland condition. On the contrary, we believe functional sagebrush communities resulting from proper grazing management will naturally support necessary vegetation components important for sage grouse survival (Section VI page 7). This includes sagebrush, which is a native climax plant species (Mueggler and Steward 1980, Beetle and Johnson 1982, Hansen et al. 1995). 
The Plan makes no effort to objectively determine the relationship between sage grouse numbers and range condition.

Section IV provides a description of habitat characteristics sage grouse require to reproduce and meet yearlong needs. We believe rangelands that are managed to "maintain the soil conditions and ecological processes necessary for a properly functioning sagebrush community" and that address the long term needs of sage grouse is an important aspect of long-term sage grouse conservation (Section VI page 7-8). We agree that few studies have been completed showing a direct link between "range condition" and sage grouse abundance. Generally speaking, the term "range condition" is a grazing management term, and does not necessarily represent characteristics associated with quality sage grouse habitat. The fact remains, however, most sage grouse habitat studies have been completed in livestockgrazed environments (Wambolt et al. 2002). This supports the notion that rangelands managed to maintain long term grazing productivity can go hand-in-hand with managing functional sagebrush communities for the benefit of sage grouse.

Re: Section VI, Pg 7; Exceptional resource management over the past 50+ years has resulted in range conditions being at the highest successional state since record keeping began. Over time, good range management results in better grass stands which reduces big sagebrush and annual forbs, especially when heavily browsed. These low successional plants are high in protein and important for sage grouse survival.

The Plan describes how, since the early 1900's, vegetation condition has improved due to implementation of proper grazing management (Section VI page 7). Research referenced in the Plan (Section V page 1) further suggests "Light to moderate grazing by cattle or managed grazing systems can improve both quantity and quality of summer forage, i.e., forbs, for sage grouse." The plant species to which sage grouse have adapted (i.e, native perennial forbs and sagebrush), are a naturally occurring part of climax sagebrush habitat types (Mueggler and Stewart 1978).

The Plan claims livestock grazing can benefit sage grouse. Where in MT specifically has domestic livestock proven beneficial to sage grouse or their habitat? Is rest rotation better than no livestock use on key seasonal sage grouse habitats? Where can FWP show rest rotation livestock grazing has benefited sage grouse nesting and brood rearing over areas protected from grazing? What evidence does FWP have that removal of herbaceous or woody vegetation by livestock within sage grouse habitat is beneficial to sage grouse? Aren't climax vegetative conditions in sagebrush and riparian areas best for sage grouse? // Grazing by domestic livestock is hardly addressed; biologists consider grazing the most damaging factor as well as the easiest to correct; it is rarely beneficial and mostly damaging in the way it is commonly applied. Re: Section III Pg 8; Drought conditions limit escape cover for juvenile birds, doesn't grazing have the same impact on the range on an annual basis? // Rest rotation grazing doesn't take into account fidelity to nest and brood rearing areas.

We believe, to be successful, the Plan must provide guidance for striking a balance between the needs of sage grouse and social, cultural, and community values (Section VIII page 1). In Montana, humans and livestock are a part of the environment. Livestock grazing can be managed in a way that is both profitable and beneficial to a properly functioning sagebrush community (Section VI page 7).

Rest rotation grazing management is one method for achieving both of these objectives. Using Hormay's design (1970) as described by Egan (2000), approximately 1/3 ${ }^{\text {rd }}$ of the range is rested yearlong and $1 / 3^{\text {rd }}$ is deferred grazing until after the growing season. This gives sage grouse and other groundnesting birds $2 / 3 r d s$ of the range to nest and rear broods during the growing season without grazing disturbance. Livestock forage and soils also benefit from scheduled rest by allowing plants to store food reserves, ripen seeds, grow seedlings, and accumulate litter between plants (Hormay 1970). Rice and Carter (1982) found rest-rotation grazing to be far more beneficial to prairie grouse (i.e., prairie 
chickens and sharp-tailed grouse) of the Sheyenne Grasslands in South Dakota than deferred rotation grazing, due in large part to the residual cover left each year. In general, managing grazing for a healthy range that supports a diverse mix of native grasses, forbs, and shrubs will benefit sage grouse and a variety of other native wildlife. By comparison, continuous grazing and grazing prescriptions that result in a loss of native plant diversity and/or result in a net loss of topsoil ultimately will result in a loss of habitat and grazing opportunity. Eliminating grazing from public lands will only place additional pressure on private lands. In order to be successful, this Plan and others must acknowledge the importance of well-managed public and private lands to the conservation of sage grouse.

Plan should include paragraph that describes benefits of ranching to sage grouse (water developments, grazing, alfalfa, bugs from livestock, grazing coarse grass to produce tender shoots). Sage grouse are secondary grazers. They rely on cattle or buffalo to maintain high protein vegetation necessary for their survival.

Section VI page 7 includes realized and potential benefits of livestock grazing for sage grouse.

Without livestock, over growth caused by the lack of grazing, would result in uncontrollable fires, totally devastating sage grouse numbers.

There are no guidelines in the plan that specify removing livestock from native rangelands.

Define "over" grazing.

A definition of overgrazing is included in the Glossary.

Re: Section VI, Pg 8. The bottom note mentions Hormay 1970. If this is included, you also need to add successful strategies for grazing cattle in riparian zones - Montana BLM technical bulletin \#4 - 1/98) or other references for riparian areas. Also if Hormay is included, there needs to be further explanation of the publication in the previous sections as there is for Best Management Practices Publication.

We have included this citation in Section VI page 8. Information on Hormay's publication and nest research results have been added to Section VI to provide further background.

Re: Section VI Pg 7, 4th Paragraph. Generally winter feeding occurs on private ground and is prohibited on Federal ground. Ungulates on wintering areas may actually help grouse during deep snow to expose sagebrush.

The concerns raised in the mentioned paragraph were meant to identify possible conflicts associated with concentrated livestock causing disturbances during the breeding season on leks or mechanical damage to sagebrush on sage grouse winter areas. Additional clarification has been added to the text.

\section{Habitat}

In our area [central and W. McCone Co.] there is probably less tillage today than there was during the homestead days. Fields dotted the entire area.

Sage grouse are dependent on sagebrush-grasslands for survival. The fragmentation or loss of sagebrush communities has reduced the distribution of sage grouse, especially along the periphery of their range (Connelly and Braun 1997, Schroeder et al. 2000). We agree there are areas that were 
farmed during the homestead days and were abandoned and eventually returned to sagebrush-grasslands (Section III page 4). Fortunately, Montana currently supports healthy sage grouse populations due primarily to its remaining expansive sagebrush-grasslands. These habitats have become increasingly important as a result of habitat fragmentation and loss (Wambolt et al. 2002).

Sagebrush is overemphasized in the Plan. I see sage grouse on my irrigated hay land. They need a mix of habitat, not just sagebrush.

The basic determinant of sage grouse existence is the occurrence of functional sagebrush communities. The Plan (Section IV) identifies a mix of habitats necessary to meet the year round needs of sage grouse. Irrigated hay fields and other non-sagebrush habitats have been identified in some areas as important cover types during certain times of the year. However, without the native sagebrush habitat to support nesting and wintering needs (Section IV pages 1 and 3), cover types such as hay fields will not support sage grouse.

A description of optimal sage grouse habitat should be included in the plan.

Section IV provides a description of seasonal habitat needs and their desired condition. It is important to note, however, all descriptions are subject to the potential of a particular area to produce these characteristics (Section IV).

A variety of incentives by USDA and other habitat programs can be developed that make it voluntarily and economically the right choice to protect key seasonal habitats for sage grouse. Payments should be made under the Upland Game Bird Enhancement Program to preserve sagebrush habitat that might otherwise be destroyed. A program should be outlined in the plan.

Since submission of the Draft Plan for public comment, Montana Fish, Wildlife \& Parks was awarded a \$1.3 million grant from the federal Landowner Incentive Program (LIP) that was matched with state funds for a total of approximately \$2.6 million. The funds will be used to purchase voluntary 30-year habitat protection agreements on privately-owned sagebrush habitats within 2 miles of active leks as well as on known wintering areas. The one-time \$12/acre agreements will stipulate no sagebrush burning, spraying, or tillage during the life of the contract. We anticipate this will be a popular program for private landowners and will result in landscape-level protection of key sage grouse habitats. When this funding is exhausted, we anticipate additional funding either through LIP or other sources. In addition to LIP, Section II describes other programs administered by FWP that serve to protect and enhance sagebrush habitats for sage grouse and other wildlife.

USDA has also included sage grouse as a priority species for their conservation programs including the Environmental Quality Incentives Program (EQIP) which can assist with grazing systems, the Conservation Reserve Program (CRP) which assists in seeding cropland back to native grasses, sagebrush, and forbs, and the Wildlife Habitat Incentives Program (WHIP), which also funds smaller wildlife habitat projects.

No net loss of sagebrush habitat is laudable but vague and impractical due to superficial analysis. This has not been scientifically established as a proper objective and has not been properly defined. // There is no means for making up habitat lost. The Plan lacks analysis which could guide methods or schedules for recreating or restoring a comparable quantity and quality of habitat. // DNRC did not adopt the "no net loss" of sagebrush habitats.

We view "no net loss" as a goal to keep in mind as agencies manage sage grouse habitats across the state. Losses of effective habitat both in terms of quantity and quality have been the cause of long term sage grouse population declines (Connelly and Braun 1997, Schroeder et al. 2000). Maintaining 
Montana's sage grouse abundance and distribution requires conserving remaining habitat. This is the highest priority among the conservation actions identified in the Plan. We agree, however, that some losses to habitat conversion will continue to occur. Management actions described in Section VI will help to maintain and improve habitat function, offsetting some losses. In addition, we have added another management action to this Section that involves using programs like CRP or the state Upland Game Bird Habitat Enhancement Program to assist interested landowners in reseeding/planting sagebrush habitats that have been converted to cropland. Reseeding, however, is not a perfect solution as it is expensive, has a relatively high risk of failure, and does not fully replace the functional characteristics of a natural sagebrush community.

Habitat variability from state to state and even within counties affects research findings. Re: Section IV, Pg 2, Brood Habitat. Habitat descriptions from Wallestad 1975 do not accurately describe brooding habitat statewide and specifically not in SW MT. The section needs either more regional detail or needs to be generalized similar to detail of Connelly 2002.

Section IV of the Plan provides research findings based on studies in and around Montana. As can be observed in the variability between research studies, differences exist between regions and even between soil types, aspects, slopes, elevations, years, grazing history, etc. We agree that habitat potential varies across the state and existing guidelines by Connelly et al (2000b) or those listed in the Plan are not standards of habitat potential, but instead guidelines that identify habitat characteristics important to sage grouse survival and productivity. We believe our guidelines are a good starting or reference point. As stated in Section VII page 1 of the Plan, habitat assessments " must be flexible and can be modified or refined according to local conditions; a certain degree of professional judgment will be required in its application."

Sage grouse rely on ranching and the ranching community relies on public land. State and federal programs will play a big role in keeping the rancher on the land.

The Plan supports communities working together to conserve sage grouse via local working groups and utilizing a wide spread of funding sources to provide incentives and improvements for conserving sage grouse habitat (Sections II and VIII).

Habitat is the "root limiting cause"; agricultural interests have contributed to diminished acreage of sagebrush habitat by burning sagebrush and plowing up native sagebrush grasslands for crops. This needs more emphasis and attention in the Plan.

The Plan adopted the broad scale objective of "no net loss in overall distribution and quality of sagebrush habitat" (Section 1 page 1). A variety of conservation actions have been identified in Section VI to guide management decisions for conserving sagebrush habitats and achieving desired habitat conditions. Section II includes commitments by state and federal agencies that emphasize habitat management. Converting sagebrush habitat to croplands has primarily been an issue on private and DNRC lands. DNRC has also committed to consider sage grouse in their management decisions. The Plan describes using incentive-based programs to help conserve remaining sagebrush habitats on private land from further burning, herbicide spraying, or plowing. FWP will continue to play a significant role in sagebrush habitat conservation on private land through the purchase of conservation easements, sagebrush protection agreements, and funding rest rotation grazing systems and other forms of habitat restoration and enhancement (Section II page 8). The USDA NRCS has committed to making sage grouse habitat a priority when working with private landowners on grazing systems, developing CRP plantings, and prioritizing wildlife habitat projects. 
Re: Section III, Pg 4. References to early habitat conversions do not include any data to substantiate claims of negative impacts by past agricultural practices.

We have provided this early anecdotal information for background and insight as to why sage grouse populations may have varied over time. The scale of habitat loss since the 1950s, in terms of herbicide spraying, burning, and conversion to cropland, has had the greatest impact on sage grouse abundance and distribution (Section III page 4). The Plan includes documentation of these more recent impacts to sage grouse in Montana (Martin 1970, Peterson 1970b, Pyrah 1972, Wallestad 1975, Swenson et al. 1987).

Monitoring sage grouse is essential but monitoring habitat is absolutely critical; if amount and quality of habitat declines, populations will surely go down.

We agree that habitat monitoring is an important part of sage grouse conservation. Section III page 5 describes our use of the GAP analysis and how we intend to refine this remote sensing product in the future to acquire a better measure of sagebrush-grassland habitat and a baseline for future inventories. Section VII describes habitat assessment techniques at the mid and fine scales, which addresses habitat quality.

Urbanization of ag lands is another big factor limiting big sagebrush. In the western U.S. 31 million acres of farm and range lands have been developed since 1971 .

We agree urbanization is a very important issue in some parts of Montana. Its impact to sage grouse habitats in Montana, however, is limited. In our opinion, sage grouse habitat lost through spraying, burning, and conversion to cropland is a more immediate and widespread threat in Montana.

Re: Section I Pg 3, \#5. Due to intermingled federal, state, and private properties, it would be costly to change the infrastructure to manage these intermingled parcels as ecological units. The rancher will need to be compensated for this as he is quickly becoming the caretaker of the open spaces in the West.

The Plan does not recommend any specific changes to ranching operations and we do not anticipate that such change will be necessary. We do agree that if improvements are determined to be necessary by landowners, working groups, and agencies, federal and state funding programs would play an important role in accomplishing these activities.

Re: Section III, Pg 4. Very little sagebrush in S. Valley Co. has been sprayed or burned. The Plan suggests otherwise and should be changed to reflect our situation.

The Plan describes habitat issues across Montana. Whereas burning and herbicide use on sagebrush habitat may not have been an issue in S. Valley County, these activities have historically been and continue to be significant threats to Montana's sage grouse habitats (Pyrah 1972, Wallestad 1975).

Re: Section III, Pg 4. Habitat Status. This discussion should include habitat conversion in ID and the probable effects on migratory segments of Montana pop's. // Re: Section III, Pg 11. Recent studies of sage grouse movements in SW MT indicate very few individuals migrate to Idaho anymore. Perhaps the migrating populations have died out and residents remain. It is possible that migratory segments of local pops have been lost due to major conversion of winter habitat in ID.

Based on ongoing research, sage grouse breeding segments in parts of Idaho move into Montana during the summer and then move back to Idaho for wintering and breeding the following spring (Section III page 1). Habitat conversion in this part of Idaho has impacted these birds. Sage grouse that breed in 
Montana have not been documented migrating into Idaho (John W. Connelly, personal communication). Regardless of direction of movements, these sage grouse habitats in Montana are known to be important for breeding segments from both Idaho and Montana.

Re: Section VI, Pg 9. We recommend adding another Conservation Action to identify the reasons for a lack of grass and forb cover in sagebrush communities and recommend practices such as prescribed fire and properly managed livestock grazing to achieve these goals.

A conservation action which calls for identifying reasons for a lack of grass and forb cover and recommending practices to increase native herbaceous understory is already included in the Plan (Section VI page 9). Actual practices to achieve improved grass and forb cover will likely vary depending on environmental conditions and local circumstances.

\section{Historical}

Disagree with Braun (1998) account that sage grouse numbers were declining throughout range by 1920's and 1930s; historical data presented at Oct 2001 Working Group Meeting and interview data should be included in plan; during this time in E MT livestock were at an all time high and sage grouse were increasing. The Plan ignored private landowner and livestock producer's comments that the largest sage grouse populations existed in Montana during a period of intensive grazing and maximum predator control. The working groups heard this in SW and E MT. // Re: Section III, several of our members testified at the public meetings in Glasgow documenting large sage grouse populations during the dry 1930s and 1940s. Range condition was at its lowest in Valley Co. during that period.

Many varied opinions and observations exist as to historical sage grouse abundance. Braun's (1998) account was a range-wide assessment of changes in sage grouse abundance based on a review of earlier sage grouse literature. Given the lack of surveys and our reliance on anecdotal information, it is very possible there were areas in Montana of high sage grouse abundance during the 1920s and 1930s. This agrees with information provided in Section III page 12, derived from landowners, sportsmen, and agency personnel.

Effects of predation on sage grouse vary over time as a result of predator abundance, changing prey abundance, disease, weather conditions, cover quality, etc. We agree that intensive, multi-species predator control would likely result in somewhat higher sage grouse productivity within the controlled areas. However, the benefits are only felt as long as intensive control continues. In our opinion, intensive predator control on a statewide level is impractical and would not be socially accepted. Instead of taking this approach, we perceive predation as a given that affects sage grouse abundance but does not endanger sage grouse viability. It is interesting to note that impacts of predation on upland nesting ducks have been shown to be considerably lower in north central Montana compared to studies in other parts of the prairie pothole region (Ball et al. 1995). The primary reason cited for higher productivity in this study was the availability of extensive native grasslands that allow ducks to spread nests over large areas, making nest predation more difficult. The study also pointed out that north-central Montana is a coyote-dominated predator community, which is far better for upland nesting ducks. Similar findings as to the value of large blocks of nesting habitat have been found in the Dakotas and Canada (Greenwood et al. 1995, Reynolds et al. 2001). This pattern likely holds true for other upland-nesting species, including sage grouse (Section III, Reproduction and Section V, Risks in General).

The "backbone" of sage grouse viability in Montana is its extensive tracts of sagebrushgrassland habitat. The underlying reason for long term declines or disappearance of sage grouse in other states has been loss of habitat, primarily in terms of quantity but also in terms of quality (Connelly and Braun 1997, Schroeder et al. 2000). In our opinion, habitat conservation is the basis for long term sage grouse conservation. This is reflected in the Plan's overall goal (Summary page ii). 
Re: Section VI, Pg 7. The argument could be made that sage grouse have benefited by earlier over grazing because sagebrush cover increased during those times.

We believe the primary benefit of livestock grazing has been the retainment of large native rangeland tracts that today provide habitat and space for a variety of native wildlife including sage grouse (Section VI). Proper livestock grazing can also be used to maintain or improve the health of sagebrush communities, continuing to provide for long-term habitat conservation (Section VI).

\section{Hunting}

The hunting season has been substantially shortened. This negatively impacts hunting opportunity without benefit to sage grouse. Reduce daily bag limit to 2 birds, while keeping the possession limit at 6 birds. Return the season length from Sept 1 to Dec 15. // Later season birds are more suitable for mounting, maybe a week in December with a 1-bird limit. // A total season bag limit may help with landowner relations. // Start the season later than September 1; hens with late hatched broods are especially vulnerable. Also limit should be changed to 2 or 1 bird. // Why were limits dropped from 5 to 2 or 3 ? 3 is marginal, 2 is not worth it.

The Plan (Appendix C) describes adaptive harvest management in which hunting season recommendations would be based on current population trend information such as lek counts. When population indexes exceed pre-determined thresholds, recommendations for hunting seasons and/or bag limits would be liberalized. On the other hand, if current indexes suggest a declining population and these parameters cross a predetermined threshold, hunting season recommendations would shift into a conservative mode. Over time, with consistent adherence to the adaptive harvest management protocol, a data set develops that can provide insights as to the effects of harvest. Ultimately, the Fish, Wildlife \& Parks Commission is responsible for setting hunting regulations that are based in part on recommendations from FWP. Specific hunting season recommendations are outside the scope of the Plan.

Reduce bag limits in some areas and cancel the season where the sage grouse is declining. If 600 fewer birds are shot each year, that would give that many more birds a chance to make it to next year and in a few years we would see more birds. // Three months of hunting pressure is too much for sage grouse. // Please put sage grouse on the protected list and stop hunting them. // Hunting needs to be maintained. Sportsmen are paying the bills on sage grouse conservation. // Re: Section IX, Pg 2, 2nd Paragraph. The statement is made that $<10 \%$ of popn is harvested by hunters. What studies or research is this statement based upon. // "Re: Table C-1, there were 325,068 birds harvested; these numbers indicate a high "form of mortality" in comparison to other physical threats; (in reference to Draft Summary page V under Harvest Management "direct effects of hunting on sage grouse are still small when compared to other forms of mortality.") Hunting and predation have to be dealt with more aggressively than the idea of a sage grouse colliding with an electric pole. // The Plan summarizes that hunting and predation are not viewed as a risk to sage grouse until habitats have been compromised; from the beginning hunting and predation have been a concern to landowners and stock producers. // "I don't know what you mean by "excess birds" when you talk about hunting them for a couple months in the fall. Please explain." // Some of the best sage grouse habitat in MT is sparsely populated, which will help management and prevent excessive harvest. // We support adaptive harvest limits for hunting. Hunting has much less impact on sage grouse populations than the decline in quality sage grouse habitat (call for habitat restoration efforts). Hunters would do their part if significant impact from hunting on sage grouse populations could be documented. // We do not understand why a species recommended for a $\mathrm{T}$ or $\mathrm{E}$ designation could continue to be hunted. 
Hunting is an important pursuit in Montana that is monitored and regulated. Like other game species, healthy sage grouse populations in Montana can support a harvest without affecting long-term abundance and distribution. Connelly et al. 2000 suggested harvest rates for sage grouse should be 10\% or less of the population. Based on lek counts, production estimates from harvested wings, and hunter telephone harvest surveys, sage grouse harvest rates in Montana are generally well below 10\% (Section IX page 7). We believe conserving existing habitats is a more pressing need for addressing long-term sage grouse conservation. Washington state applied very restrictive hunting seasons beginning in 1957 and closed their hunting season entirely in 1988. Habitat loss to domestic crops continues to cause a downward trend in abundance and distribution in Washington, in spite of restricted hunting (Shroeder et al. 2000). We have added additional information to Section $V$ to try to clarify why hunting is not a longterm threat to sage grouse. Generally speaking, Montana's habitats and sage grouse populations are productive, sustainable, and capable of supporting a managed hunting season. In this respect, sage grouse are not much different from other managed game species. Based on the past 40 years of lek survey data, we have no evidence showing hunting to have any kind of long term impact on sage grouse viability. However, to be responsive to short-term changes in sage grouse abundance, an adaptive harvest strategy has been developed for consideration by the FWP Commission (see Appendix).

Hunting regulations show sage grouse hunting to be open where there are no sage grouse. I think it is important to adjust boundaries of open hunting to reflect actual distribution to diffuse future criticism.

Successful hunters will hunt in areas where the species they are pursuing is available. Hunters generally do not actively hunt peripheral areas where sage grouse densities are lower because a lower density of birds usually means less opportunity to bag a grouse. In our opinion, adjusting hunting boundaries around sage grouse distribution would not provide any additional conservation to the species but may actually direct uninformed hunters to areas where sage grouse densities are low.

How much money does FWP make from selling sage grouse licenses?

FWP sells upland game bird hunting licenses that allow hunting of a number of upland game bird species during the appropriate season. Most upland bird hunters pursue a number of species and the number of sage grouse-only hunters is probably quite small. Data from check stations and statewide harvest surveys show statewide sage grouse harvest has declined significantly (Figure III-2).

Why are the number of males at leks remaining fairly constant but the harvest is going down?

It is correct that average male attendance on surveyed leks has fluctuated from year to year but overall remains fairly constant (Table III-1). Sage grouse harvest, however, has declined since the 1960s. Changes in hunter numbers may help partially explain the decline in harvest. Based on telephone hunter surveys, the number of sage grouse hunter-days has declined approximately $43 \%$ since 1975 (when sage grouse hunting survey data was first differentiated from other types of upland game bird hunting). It is possible that sage grouse abundance may have also declined sufficiently in some locations to affect hunter harvest rates in those locations. We do not, however, have a measure of changes in statewide abundance to know what, if any, affect this may have had. A lek survey protocol will be developed to better estimate changes in overall abundance over time (Section VII, Research Needs).

Data should be collected from brood surveys (2-week period) to recommend harvest quotas. It is not good biology to only rely on number of males on strutting grounds. Check station data should also be used. All three datas should be used. 
Annual lek surveys have been used to monitor abundance trends. Although production cannot be estimated from these counts, harvest rates have tended to follow abundance trends from lek counts

(Figure III-2). FWP continues to utilize telephone harvest surveys to assess annual harvest and a renewed effort has been made to collect harvested wings in wing barrels. These wing surveys provide a trend over time in production of sage grouse.

Re: Section III, Pg 12; need to include current hunting season and bag limit.

We have added the 2003 hunting season and bag limit as suggested.

\section{MINERALS}

Rather than engaging in oil and gas development as described in the introductory letter, FWP should spell out the hazards associated with this type of development in sage grouse habitat. The Plan should spell out specific mitigation measures where disturbance cannot be avoided.

Section VI, Pages 11-13 describe potential impacts of mining and energy developments on sage grouse habitat. A variety of issues and conservation actions designed to reduce or mitigate impacts are described.

Re: Mining and Energy section, "surface occupancy" and "surface use" need to be defined in Glossary.

Definitions have been added to the Plan Glossary.

Re: Section VI, Pg 12. This section indicates only oil and gas activities have negative impacts during specific time periods. Other human activities such as photography and nature watching should also be restricted during the same time periods.

Section VI pages 25-26 describes issues related to recreational disturbance and lists potential actions to reduce impacts of nature viewing and other recreational pursuits.

Re: Section VI, Pg. 12, Increased Human Disturbance \#2 and \#3. Timing restriction should be changed to March 1-June 15, consistent with lease stipulations. Same for pgs 21, 22, 23 and change to Dec 1-March 31 .

\section{Suggested changes were made to the Plan.}

Re: Section VI, Pg13. Noise can disrupt breeding...Rewrite \#2 timing restriction to be clearer about hours of restriction. Restrict use of heavy equipment that exceeds 49 decibels within 2 miles of a lek from 4 a.m.-8 a.m. and 7 p.m. - 10 p.m. during March 1-June 15.

\section{Suggested changes were made to the Plan.}

Re: Section VI, Allows no surface occupancy within .25 miles of an active lek. What is this based on? WAFWA guidelines call for locating $>3.2 \mathrm{~km}$ from active leks whenever possible. Human activities within view of or $<0.5 \mathrm{~km}$ from leks should be minimized during the early morning and late evening when birds are near or on leks." This is a critical compromise which may continue to inhibit the long-term conservation of sage grouse in MT. 
The .25-mile no surface occupancy lease stipulation was based on the best available information at the time the leasing document was approved in the RMP. Stipulations on leases may be changed in a RMP amendment if new information is available. BLM is co-funding research studies to help us understand required disturbance buffers and necessary mitigation to adequately protect sage-grouse during energy development.

\section{MONITORING}

I would suggest surveying leks three times during the breeding season to firm up data. ID FG has done that and found numbers of males varies over the breeding season.

Lek counts provide an index of sage grouse breeding abundance from year to year at a particular lek or group of leks. The lek monitoring protocol (Section VII pages 12-14) describes block, route, and incidental surveys. Annual block and route surveys are completed in core sage grouse habitats and are used to determine annual changes in abundance. These provide a long-term assessment of trends in abundance within the survey areas and help in assessing what fall hunting conditions may be like. Incidental surveys are either attempts at documenting new leks or periodic re-visiting of leks. These are important to assess long term changes over large, distribution-wide areas. Biologists try to balance these two types of surveys for fulfilling short and long term population assessment needs. For both survey types, a protocol of conditions, e.g. weather conditions, disturbance, and survey timing is followed to reduce survey variability. Limited survey time and work force makes revisiting leks 3 times very difficult and would effectively reduce our ability to complete many incidental surveys.

Re: Section III, The population dynamics discussion in Section III should identify lek counts as the best available means of obtaining an index of relative change in sage grouse abundance, but it also should discuss some of the method's shortcomings and need for more statistically reliable means of estimating changes in abundance, which should be reflected in "Research Needs" - Section VII

We agree that lek count information needs to be qualified as to its shortcomings. Additional information has been added to Section III related to this. Section VII, Habitat and PopulationPopulation Dynamics calls for a "rigorous monitoring protocol...to assess population status and trend at the fine and mid-scale." Statistical reliability would be addressed in this protocol.

\section{NOXIOUS WEEDS}

Aggressive control of small weed patches can be done with chemical or integrated means without harming wildlife or livestock. When allowed to spread, control efforts will negatively impact wildlife.

We agree that noxious weeds can be a significant detriment to the long term health of sagebrush communities. Section VI Noxious Weed Management promotes a variety of conservation actions to reduce the establishment and spread of noxious weeds. Actions such as educating personnel to identify and report infestations promotes early detection and treatment.

The toxicology statement may be interpreted as a no-control zone within sage grouse habitat. There is no scientific evidence that herbicides and other control measures do in fact have detrimental effects on sage grouse. 
Section VI Page 15 states "resource managers must realize that untreated noxious weeds are ultimately more effective at competitively displacing desirable plant components than short-term, transient impacts from proper herbicide application."

Re: Section VI, Pg 15. If livestock movements must be delayed long enough to prevent spread of noxious weeds, how will this be imposed on wildlife?

As is implied by this comment, we do not have full control of noxious weed spread. However, the Plan does detail specific actions that are known to reduce the likelihood of establishing and spreading noxious weeds.

\section{OHV}

We need to eliminate off-road vehicle travel. Grouse habitat is easily traveled by ORVs and they spread weeds.

Developing off road travel regulations is outside the scope of this Plan.

\section{OTHER SPECIES}

Need more of an ecosystem approach, plans for conserving other species conflict with sage grouse (e.g., prairie dogs, mtn plover, burrowing owl), Landowners are caught in the middle, leaving everything for each species with unique requirements...too many species-specific plans which micromanage each species.

We agree that an ecosystem approach to managing wildlife habitat is essential for conserving the host of wildlife species that occur in sagebrush-grassland communities. Specific issues related to other species will be addressed at the local levels as the various species plans are implemented. Local working groups as described in the Plan will identify local issues and develop and implement creative solutions (Section VIII).

Conserving the sagebrush grasslands for sage grouse will benefit all the species which rely on that habitat.

We agree healthy sagebrush communities that support sage grouse will also support a host of other sagebrush dependent and sagebrush associated wildlife (Wambolt et al. 2002).

The Other Wildlife section is grossly inadequate. FWP knows that the increased number of elk in SW MT has impacted sage grouse habitat. Re: Section VI, Pg 32. In order to manage for retaining and promoting adequate residual cover, reductions in big game populations may be required. This should be clearly stated in the Plan.

FWP manages elk numbers based on objectives described in the statewide elk management plan. If elk numbers exceed those objectives, FWP is required to reduce herd sizes. Over the past decade, elk numbers have been significantly reduced in the Dillon area. We are unaware of specific locations where elk grazing has affected sage grouse habitat to the point of negative impacts to sage grouse. If specific areas were identified where these types of impacts by elk were occurring, changes in management of elk herds would be considered. 
The Plan made no connection between antelope habitat use and sage grouse. Antelope presence on the landscape in many cases provides insight into historical suitability of the areas for sage grouse (Pyrah 1987; Prellwitz 2002). Habitat preferences and needs are very similar between the two species.

We agree that sage grouse and antelope habitats are similar. However, we believe sage grouse are more closely associated with sagebrush for food and cover. By comparison, antelope are known to travel well outside of sagebrush habitats, especially during summer. The primary method for determining potential sage grouse distribution is accurately assessing sagebrush distribution (Section III).

\section{PESTICIDES}

Re: Section V, Pg 2; 35,000 square miles of western rangeland were treated with insecticide 1995-1990; need data specific to MT.

Our purpose in including this statistic was to show the relatively large area that has been treated with insecticides in the past and to identify insecticide use as a potential issue of concern for sage grouse conservation in Montana.

\section{PLAN DOCUMENT}

Throughout document replace "canopy closure" with "canopy cover" or include a definition of canopy closure.

made.

We agree. In some publications, "closure” is an overhead forest term. This revision has been

Threats posed by livestock grazing, coal-bed methane development, weeds, and other habitat fragmentation have not been adequately covered. The Plan needs definitive parameters for mitigating these threats, legal procedures must be stated with clear, concise directives.

Section VI describes 12 broad issues of concern to sage grouse conservation and lists related specific issues and conservation actions intended to guide land managers and local working groups in their decision making. We believe further specificity would reduce the flexibility for working groups to develop creative solutions to management issues.

Change the term "public land" to "state or federal land" as appropriate throughout document; change supported by recent court case.

Our use of the term "public land" is defined in the Plan's glossary. We realize there may be a different legal definition for this term but have decided to continue its use, as defined, for the sake of brevity.

The WAFWA guidelines should not be included as an index to the Plan. Inclusion furthers misinterpretation and misuse of the guidelines by federal agencies and thwarts the success of local working groups. Inclusion of the WAFWA guidelines will only add to the potential for litigation. // Plan should utilize Connelly et al. 2000 guidelines as the basis for evaluation of habitat sufficiency until and unless these guidelines are shown to be inappropriate for sage grouse conservation in MT. 
The WAFWA guidelines (Connelly et al. 2000) were used by the Montana Sage Grouse Working Group as a technical reference. Based on a broad compilation of professionally refereed sage grouse research, the guidelines describe sage grouse biology and habitat requirements, identify issues of concern to sage grouse conservation, and describe general strategies for achieving effective conservation. The WAFWA guidelines are included because they will likely provide additional guidance to land managers and local working groups to help in decision making. Although many studies were used to develop the WAFWA guidelines, the authors concede there are gaps in knowledge as well as variations in habitat potential.

A better approach to the Plan would be to clearly articulate what ideal sage grouse habitat looks like, identify the 3 primary limiting factors, and outline procedures or recommendations for addressing these factors.

Section IV describes breeding, brood rearing, and winter habitats based on sage grouse habitat research. The Plan describes a variety of issues that can both negatively and positively impact sage grouse. Limiting factors can vary considerably from one area to another and are typically described at a local level. As questions arise about limiting factors, local working groups, wildlife biologists, and land managers will need to determine what factors may be limiting sage grouse productivity and survival in a particular area.

All metric measurements should be expressed in English.

We agree and have included English conversions for all measurements.

Background info on mandates and policies of the respective agencies could be moved to appendix.

We have included mandates of each of the agencies to describe the various management perspectives. Each agency fills a specific niche in sage grouse conservation characterized by unique opportunities and constraints, which are also described in this section of the Plan.

Change "sagebrush steppe communities" to "sagebrush grass communities", more common terminology. "Steppe" is not defined in the glossary.

We added a definition of "steppe" to the glossary and retained use of the term. Steppe is a widely used term that links grass and shrub vegetation occurrence to a particular moisture regime (Daubenmire 1970).

I fail to understand why the Extension Service is not a part of the Conservation Plan. The Extension System would allow some County agents to support local working groups.

The Extension Service has not been excluded from the process. As with all interested parties, the Extension Service is welcome to take part in this planning process and extension agents in particular could provide valuable support to local working groups.

To further reduce the potential misuse of the numeric values, it may be helpful to change the title of Table VII-2 (page 9, Section VII) to "Suggested nesting and brood-rearing..."

In response to this suggestion, we have added to the title of Table VII-2 a cross-reference directing users to review introductory paragraphs of that section in which the appropriate application of habitat assessment values is emphasized. 
Re: Pg ii. You need to define what is meant by the term "integrity" as used regarding sagebrush steppe communities or use a more standard terminology (e.g. cover leaf area index, density, height, etc.).

Rangeland integrity is defined in the glossary.

Re: Section 1 Pg 3. In addition to a-g "site potential" of a particular habitat area needs to be added.

The paragraph preceding this (Section I page 3, Fine Scale Habitat Objectives) lists site potential as one of the basic factors necessary for achieving a desired condition. In addition, item $b$. of the list identifies the potential for a site to support a variety of species including wildlife.

Re: Section VI; more clarification is needed regarding relationship between Connelly guidelines and the Plan's conservation actions.

The Plan's conservation actions were developed by the Montana Sage Grouse Work group from a combination of Connelly's guidelines, public input, and other resources.

Re: Section VI, Pg 1. Long term needs to be defined. Greater than 50 years is used in another section. Also, what is meant by biological and physical limitations of a site?

Long term refers to the foreseeable future. With regard to sage grouse conservation, if effective long-term conservation strategies are implemented and sustained, and no new issues of significance develop, we anticipate the viability of Montana's sage grouse to extend through the foreseeable future. The Plan is not a recovery effort of a threatened species but instead a proactive approach for maintaining sustainable sage grouse populations.

In Section VI, biological and physical limitations refers to the ability of a sagebrush-grassland site to recover from prescribed fire and the biological impact prescribed fire would have. Factors such as moisture regimes, soil texture, seed sources, potential for invasive weeds, predicted fire intensity, habitat function for sage grouse and other species, impacts to sagebrush and other vegetation, sagebrush recovery time, as well as other factors of local consideration need to be identified as part of a prescribed fire plan. In addition to these, post-burn spring and summer growing conditions strongly affect big sagebrush seedling survival (Welch in preparation).

Re: Section VI, Pg 8. What soil conditions and ecological processes are necessary for a properly functioning sagebrush community? What is a properly functioning sagebrush community? This needs to be more specific.

A definition of "functional sagebrush community" has been added to the Plan. We consider a contiguous block of habitat that supports sagebrush and a diverse mix of native grasses and forbs, capable of sustaining sagebrush-associated wildlife as being functional. A variety of environmental factors (e.g. soils, moisture regimes, grazing accessibility, past fires, slope, aspect) affect what vegetation grows at a particular site. These factors result in varying densities, heights, and species complements of grasses, forbs and shrubs. Within this patchwork, sage grouse select for various habitat characteristics to meet life stage and seasonal needs.

Re: Section VI - Pg 9, 2) top of page - change to read "identify reasons for lack...and recommend/implement practices..."

This addition has been made. 
Re: Section VII; Planning maps at the mid-scale are needed; sage grouse population and habitat data are needed at the fine scale efforts.

This may be in reference to a mistake in Section VII, Page 3 where "fine-scale" was mistakenly used in place of "mid-scale". This comment appears to support mid and fine-scale information needs as described in the Plan.

Re: Section VII Pg 1. Using Assessment Framework. You should be using biologists to determine the needs of the sage grouse and resource ecologists to determine how to manage the resource to attain the needs of the birds.

Land health (Standards) assessments on federal lands are an interdisciplinary process.

\section{PLAN PROCESS}

The Plan has substantial procedure and legal deficiencies as relates to FWP's compliance with MEPA. Re: Section IV, Pg 8, we believe FWP's alternatives, analysis, and decision should extend well beyond the narrow scope of population objectives and an adaptive harvest management strategy. A range of alternatives should be presented for Montanan's to choose from such as used for the Mountain Lion EIS.

The range of alternatives must be dictated by statutory authority relative to possible action items or management prescriptions. FWP does not have authority for land management decisions on federal lands. However, FWP will consider possible state actions resulting from the Plan in a MEPA analysis.

Why were no sportsmen included on the working group. Sportsmen foot the bill for conservation and they were left out in the cold. It seems to be slanted toward anti-livestock grazing and anti-hunting groups.

We believe sportsmen were well represented on the State Working Group. The list of sportsmen included: Glenn Hockett of the Gallatin Wildlife Association, John Weigand of the Headwaters Wildlife Association, Skipp Tubbs of the Montana Falconers Association, Ben Deeble of the Western Montana Upland Game Bird Association (a second affiliation to an organization, not listed in the Plan), and Chris Beebe of the Montana Wildlife Federation.

No language was included on the Federal Data Quality Act which allows challenge of the scientific basis for agency decisions. This Plan could and should be objected due on basis of conflicting and incomplete information. // In addition to public comments, economic analysis reports and environmental impact statements must be considered if working under MEPA. If attached to BLM allotments, the Plan could open up the possibility of damage to permittees as well as the county.

The Plan is intended to guide sage grouse conservation in Montana. Involved agencies are responsible for completing necessary NEPA or MEPA assessments prior to initiating or changing management practices. This would include, when and where appropriate, sage grouse conservation strategies identified in the Plan.

Section 87-1-201(9)(c) mandates that any management plan developed by the department be developed subject to the requirements of MEPA. The Plan is not MEPA sufficient. The MEPA EA will be developed after the State Workgroup has adopted the Final Plan. Local work groups are expected to work within the guidelines of the Plan and implement conservation strategies based on a management plan that is not MEPA sufficient. 
The EA will be developed concurrently with the most recent set of revisions to the draft plan. Any changes that result from the EA scoping process that are specific to FWP commitments, actions and alternatives, will be incorporated into the final version. The Director will sign the final version as a record of decision and the executed plan will be routed to all partners (statewide working group) for cosignature. NEPA compliance by federal partners will occur during their planning processes as they update allotment management plans, etc., using the document to provide guidance in those actions. The fully executed agreement will provide the structure for local working groups as they assist with delivery of regionally appropriate conservation strategies as outlined in the plan.

\section{POPULATION}

Need something in plan about transplanting sage grouse to increase/bolster populations (i.e., successes and failures)

Fortunately, Montana's extensive sagebrush-grassland habitats support sustainable sage grouse populations and transplanting in these areas is not necessary. Along the periphery of Montana's sage grouse distribution, where sage grouse numbers have dwindled due to habitat loss, transplanting would not provide satisfactory results unless substantial habitats were restored.

Drought has not been factored into the population decline. // The Plan seems to have a theme that status quo should be maintained. Is that sufficient for sage grouse conservation if sage grouse are declining? How will this arrest the decline? // The Plan describes over grazing in the late 1800s and early 1900s. This leads one to believe that the decline in sage grouse began at this time while the rest of the plan suggests numbers declined in the late 1970s to the late 1980s. If they have declined, it is important to know when to decide what may have caused it.

The historical account on grazing was not intended to suggest sage grouse have been in a decline since the late 1800s. In fact, lek count data suggests male attendance at surveyed leks has remained fairly stable since the 1950s (Table III-1). The Plan reports an estimated 30\% decline in population based on Connelly and Braun (1997). This estimate was derived from a comparison of male sage grouse lek attendance during 1986-1995 versus long-term lek count data preceding this time period. The authors of the report suggest drought may be one of the factors affecting the decline. We agree. The Palmer Drought Severity Index (http://www.ncdc.noaa.gov/onlineprod/drought/main.html), calculated for weather divisions 4, 5, 6, and 7, which make up the majority of sage grouse habitat in eastern Montana, portrayed normal to droughty weather dominated the 1986 through 1995 time period. By comparison, the early 1960s through 1985 were characterized as normal to above normal moisture with only 3-6 years of severe drought (varied by weather district). Drought has been documented to affect sage grouse productivity, causing dramatic fluctuations in abundance (Eustace 2002). However, as drought subsides, sage grouse productivity has also improved (Wallestad and Watts 1973, Eustace 2002).

By comparison, habitat deterioration and loss across the sage grouse's range has resulted in sage grouse population declines that have persisted (Connelly et al. 2000b, Wambolt et al. 2002). A number of authors have described impacts of habitat losses in parts of Montana (Peterson 1970b, Martin 1970, Pyrah 1972, Wallestad 1975, Swenson et al. 1987). Many of the areas impacted by habitat conversion lack sage grouse survey information and we therefore do not have a good statewide estimate as to the long-term effects on sage grouse abundance (Section III). In spite of habitat losses, Montana still sustains the majority of its expansive sage grouse habitats. Generally speaking, we believe the sagebrush habitats in Montana are relatively healthy compared with other parts of the sage grouse's range. That is, remaining habitats have not experienced extreme understory depletion or invasion of exotic grasses. 
The Plan's purpose is to "Provide for the long-term conservation and enhancement of the sagebrush steppe/mixed-grass prairie complex within Montana in a manner that supports sage grouse and a healthy diversity and abundance of wildife species and human uses." The Plan identifies management actions and guidelines that help conserve, enhance, and restore sage grouse habitats on both private and public lands. We anticipate, with the help of landowners and land managers in implementing the Plan, habitats supporting the majority of sage grouse will, over time, improve in productivity while accommodating human needs such as livestock grazing, mineral extraction, and recreation.

Re: Table I-2, number of active and inactive leks observed over time needs to be included to show both sides of the equation.

We agree, this would be very useful information. Unfortunately, sage grouse leks have not been evenly surveyed across their distribution in the state and some parts of their distribution have lacked any survey information. In addition to this, a number of anecdotal reports of sage grouse leks have been documented over time without any data for determining the quality of the information. To firm up our understanding of sage grouse distribution and abundance, an intensive survey effort is underway to find new or undocumented leks and to determine the status of leks identified in old reports. This lek inventory in the state will provide a benchmark for assessing future long-term changes in sage grouse distribution.

Re: Section I, Table 1-3. Lek attendance objectives need to be better defined. Does average number of males per lek intend to apply region wide (i.e., 35 males for all leks) or specific for each individual lek?

The average males per lek are an objective set for each region based on past survey data (Table I-2). Each region's lek attendance objective (Table I-3) is an average of all the leks surveyed in the region during a year of high population levels.

Re: Section I, Pg 7and Section III, Pg 5. Using lek information for only those leks with 10+ years of information excludes the majority of leks in SW MT. Using only data in the Plan disregards earlier data that documents substantial changes in the number of attending males. The Plan needs to provide some discussion of how many leks statewide and ecoregion-wide have that quality of data. Significant declines in the 1970s and early 1980s occurred in SW MT when monitoring was not continuous. Trend determinations from more recent monitoring use a baseline number of males that is already lower than was present in earlier years (pre-1970 declines).

As of 2003, southwest Montana has 29 leks with 10+ years of consecutive count data. Table III-1 shows how the number of leks (statewide) with 10+ years of count data has steadily increased to a total of 72 leks in 2001. We believe this filtering technique gives a better statewide trend of male lek attendance over time. If we were to include shorter data strings, the wide variability in lek sizes would influence lek attendance averages in a way that adds "noise" without substantially contributing to the trend analysis. In addition, the 10-year filtering technique eliminates use of data from satellite leks, which are generally smaller and temporary in nature, but occur during population peaks. Whereas this technique is used on a statewide basis, the Plan does not preclude using earlier count data with less than 10 years of consecutive counts at a local level.

Re: Section III, Pg 5 and Table III-1 are not consistent with Figure III-2.

We do not detect a discrepancy between these three parts of the Plan. Figure III-2 includes both Harvest and Lek attendance information corresponding to two separate $Y$ axes. This may have been a source of confusion. 
Re: Section III, Pg 8. The Plan indicates that drought increases mortality of sage grouse. We have experienced a prolonged drought throughout the West for the past decade which could be a significant factor in declining sage grouse numbers. // Re: Section IV. The importance of drought and wet years on grouse populations should be expanded. // Re: Section VI Pg 23. There is a strong correlation between sage grouse numbers and climatic patterns. For instance, sage grouse numbers were relatively high during the wet period in the 1970s, despite (or because of?) "extensive" chemical control of sagebrush during the 1950s, 60s, and 70s.

We agree that weather patterns and especially drought and spring moisture conditions (Eustace 2002) can have a significant overriding effect on sage grouse productivity. As described in Section VI, Page 5, climatic conditions are typically responsible for temporary fluctuations in sage grouse abundance. These short-term fluctuations (approx. 10 years) can quickly reverse with a change in weather pattern. In contrast, habitat deterioration, fragmentation, and loss result in long term impacts to sage grouse abundance and are more likely to persist. Because of this, we believe habitat conservation is the key to effective long-term sage grouse conservation planning.

Re: Section III, Pg 11, The Plan refers to sage grouse declines due to habitat loss. However this doesn't correspond with the grouse population count through the 1990's and 2000's (Section III, Pg 6). The Plan indicates that sage grouse populations declined as a result of sagebrush manipulation programs in the 60's and 70's. However sharp declines did not occur until the mid-1980s.

Information presented in Section III page 11 is based on a county-by-county summary of sage grouse abundance observations in each sagebrush ecotype. Some of the areas that experienced declining populations due to habitat loss lack long-term survey information. By comparison, Table III-1 is a summary of statewide data from leks with 10 or more consecutive years of data. These statewide abundance indexes do not reflect impacts of local habitat changes, especially where leks were not monitored. In many cases, long-term data collection has been in the relatively stable core sage grouse habitats, outside of peripheral habitats where the majority of conversions to cropland has occurred.

Re: Section III. Interpretations of population decline were based on numbers from the 1950s when sage grouse populations were probably at a peak in density, age class diversity, and extent because of fire suppression and overgrazing by livestock in the late 1800's-early 1900's. Given this, we question whether the 1950s should be the benchmark.

We do not intend to use the 1950s as a benchmark for sage grouse abundance. Sage grouse abundance index objectives are listed in Table I-3 and are based on lek survey data from the past 25 years. This comment may have been in response to a sentence in Section III page 5 which states: "Counts of males on leks during spring have been used since the mid-1950s to provide an index of relative size of breeding populations (Eng 1954, Wallestad 1975)." This statement was intended to mean, annual lek surveys were initiated in the 1950s and are used as an index of sage grouse abundance.

\section{PREDATION}

Predation should be high on the list of threats to sage grouse populations. When fur prices were higher and government trappers were at work, there were many more upland game birds. Sage grouse numbers decreased after 10-80 was banned. FWP needs to put more time into predator control. Habitat can't hide them when predators are at high numbers. Red fox and raccoons are relatively new arrivals to sage grouse habitat. // Brenden Moynahan's first year nesting and chick survival resulted in 59\% nest predation and 2 broods out of 39 surviving to the 30-day juvenile stage. // An honest, unbiased research effort would correlate the negative relationship between predators and sage grouse populations. // Re: Summary 
VI, the Plan points out that one study cited by Connelly has shown predation to be a significant limiting factor and predation should therefore be considered more than just "an expected component of natural mortality" // The sage grouse cycles appear to correspond closely to predator population cycles. Most recently, the diseases which have reduced predator numbers corresponds to high sage grouse numbers depicted in Table III-1. // Re: Section III, Pg 10; Need to expand the discussion on predation beyond prey species to include restrictions on trapping, shooting, or taking of raptors and other predators; as well as creation of predator habitat (such as reservoirs) favoring increased predator pop's. // Re: Section V, Pg 1; We disagree; we could present data a different way (i.e. habitat isn't a risk factor unless predators and hunting pressure are no longer in balance with natural system). // Re: Section V, Pg 1. Top - is loss to predation not a "natural mortality"? What studies support the contention that hunting and predation are only risk factors to sage grouse populations when habitat is compromised?

We agree that predation does impact sage grouse populations. As the comments describe, predator control and its benefits are temporary. During periods of more effective predator control, sage grouse abundance likely responded positively. Other temporary factors also affect sage grouse and predators such as weather, alternative prey abundance, and predator diseases including mange and canine distemper. We believe the long term conservation of sage grouse in Montana requires addressing the threats to their long term viability. That is, conserving the quality and quantify of habitat that presently supports sage grouse. Whereas predation will cause fluctuations in sage grouse abundance as predator and prey abundance varies, habitat deterioration or conversion produces long term and sometimes irreversible declines in sage grouse populations (Martin 1970, Swenson et al. 1987, Connelly and Braun 1997, Schroeder et al. 2000). Also, predation is believed to have a greater impact on uplandnesting birds as habitats become fragmented (Ball et al. 1995).

The Plan needs to clearly state FWP's stance on predator control methods and what if any funds will be expended for predator control. // Don't rely on predator control as a substitute for improving habitat. Predators have been eating grouse for 500,000 years; sage grouse have adapted to predation. // Sage grouse have evolved with many natural predators. Predation is a symptom of degraded or fragmented habitat. FWP should not be "gifting" \$100,000 each year to Department of Livestock on predator control (II-3).

Section III, Page 3 describes FWP's efforts to maintain a working relationship with private landowners. One of the items listed is the department's annual \$100,000 contribution to Department of Livestock for controlling predators. This is the extent to which any broad-scale predator control effort is planned by FWP. The Plan's goal statement and management actions are primarily habitat-based (Section I).

\section{RESEARCH}

The Plan did not cite Dr. Alma H. Winward, USDA Forest Service nor was he ever consulted regarding sagebrush ecology, although he is a leading authority on sagebrush.

As we understand it, Dr. Winward's work was mostly completed in US Forest Service Region 4, which includes southern Idaho, Nevada, Utah, and extreme southwest Wyoming. Where possible, we have strived to draw conclusions from research that is professionally refereed and specific to Montana. Again, as we understand it, Dr. Winward's work does not fit one or more of these criteria. The Plan does, however, cite most of the pertinent sagebrush and sage grouse research completed in and around Montana. 
The Plan falls short of any reference to Dr. Daubenmire's work with big sagebrush or his publication which points out 10 good scientific reasons not to manipulate big sagebrush.

Daubenmire (1970) described 7 or more habitat types in Washington where sagebrush is a naturally common or dominant shrub. He also lists a number of reasons why burning or spraying sagebrush may provide temporary range improvements but long term range decline.

Research is needed to actually find out how threatened sage grouse are. Your own data shows their numbers increasing. Species populations naturally fluctuate in a dynamic system.

Montana supports a healthy sage grouse population and, therefore, the Plan is not a recovery effort. Unfortunately, this is not the case for all states that historically supported sage grouse. Sage grouse have been eliminated or significantly reduced in abundance over parts of their distribution due to habitat deterioration and loss. Unlike population fluctuations experienced in Montana due to a host of dynamic environmental factors, loss of effective habitat produces long term population declines (Martin 1970, Swenson et al. 1987, Connelly and Braun 1997, Schroeder et al. 2000).

Re: Section III, Pg 8. SW MT radio telemetry study documented $50-80 \%$ annual mortality for adult males and $14-50 \%$ for adult females. Only $20 \%$ of losses from hunting. Should be included in the Plan but in context of small sample size.

This sample was indeed small, totaling less than 20 birds. We do not feel this is a sufficient sample size to extrapolate any firm conclusions.

Re: Section III, most studies are done in other states which may not be indicative of the Wyoming big sagebrush-silver sagebrush complex in E. MT; rather than outside citations, admit no research has been conducted in MT; issues could then be prioritized to guide future research.

Research in Montana and other states provide insights for identifying important sage grouse habitat needs. Although specific vegetative characteristics of sage grouse habitat may vary geographically, the basic needs of nesting, brood rearing, and wintering habitats are similar across their distribution. The similarities among research studies reveal common habitat needs of sage grouse and provide a general point of reference.

Section III, Research lists and describes a number of past studies and present research projects in Montana. Section VI, Livestock Grazing calls for research to help identify and evaluate the effects of various grazing management plans. Section VII, Research Needs lists issues that require additional study in Montana.

Consider the following research: Holloran and et al., Wyoming Coop Res. Unit, JWM (submitted?); Heath et al. 1998, M.E. Watters et al. Ecoscience 9:314-319

Holloran completed sage grouse research in eastern Wyoming but has not yet published his work. Heath et al. 1998 compared sage grouse productivity on 3 different ranches and measured vegetative characteristics at 42 nest sites, comparing them to random sites, in south-central Wyoming. As with other studies, they found sage grouse generally selected nest sites with greater total shrub cover and taller grass, residual grass, and sagebrush compared to random sites. They reported mean grass and residual grass heights at 42 nest sites as 16.6 and $10.6 \mathrm{~cm}$ (i.e., 6.5 and 4.1 inches), respectively. They concluded that predator control had limited value to sage grouse populations and could not be substituted for maintaining $>10 \mathrm{~cm}$ (4 inches) of residual grass cover for nest concealment through sound grazing management. They recommended against shrub control in areas that support $25-33 \%$ shrub canopy cover within $5 \mathrm{~km}$ (3 miles) of leks, as these were important nesting areas. They also promoted off-site water to 
improve riparian areas for brood rearing habitat. Watters et al. 2002 studied the effects of vegetative cover and height on predation of artificial nests in Alberta, Canada. Richardson's ground squirrels were the primary nest predator in this study. Trimming grass around artificial nest sites did not affect nest fate. They concluded managing for tall, dense forbs and sagebrush would increase sage grouse nest success on their project area.

Each of these studies points out local variations but also tend to emphasize a similar central theme. That is, certain habitat characteristics are important for sage grouse survival and reproduction. Similarly, guidelines in the Plan emphasize specific habitat characteristics that must be applied with an understanding of site potential and local conditions (e.g., predominant grass and shrub species, rainfall, soils, etc.).

Re: Section VII, Pg 15; instead of effects of hunting to determine the "maximum harvest rate" establish a "sustainable" harvest rate that is consistent with the long-term increase of sage grouse pop's.

We have changed the term to optimal. This is intended to mean, a harvest rate that is in balance with recreation and sage grouse conservation.

Re: Section VII, Pg 15; expand predation/habitat fragmentation research to also evaluate the relationship between all predators on sage grouse when habitat conditions remain constant.

We agree that an assessment of relationships between predation and habitat would require comparing all types of predation on fragmented vs. intact sagebrush habitats as well as healthy vs. poor condition sagebrush communities.

\section{ROADS}

There are a number of contradictions between what is in the Plan and how agencies have been managing. FWP and others want more access to public lands but the Plan suggests fewer roads would be better.

The Plan describes potential issues related to roads and effective sage grouse habitat. In some circumstances roads, disturbance associated with roads, and weeds can be a detriment to sage grouse and other wildlife. Section VI of the Plan calls for assessing sage grouse habitat use with regard to existing roads and when building new roads. Factors such as timing and level of traffic, sage grouse habitat use, and lek location would be considered. With regard to breeding activities, sage grouse habitat is remote and breeding takes place during a time when very little human disturbance generally occurs. Mineral activities that require new roads and higher disturbance levels would be more likely to impact sage grouse during the breeding period. Conservation strategies that can be used to reduce the impacts of new and existing roads would be applied on a case-by-case basis. The Plan does not call for large-scale road closures.

Roads continue to be a significant and growing impact to sage grouse, contributing to their demise (Patterson 1952). Road closures, rehabilitation and seasonal management will be required to address the problem. Not adequately addressed in the Plan.

Section VI of the Plan provides a variety of conservation strategies for managing roads, recreation, and mineral development in sage grouse habitats. Applying these strategies will require customizing them to specific circumstances and will involve assessment and analysis by agencies and working groups at the local level. Throughout the Plan, we have strived to achieve a balance that provides guidelines but also allows flexibility for agencies and local working groups to effectively achieve sage grouse conservation under local conditions. 


\section{STRUCTURES}

(Power Lines and Fences)

I don't think raptors using fence posts as perches is much of a problem and I've never seen a sage grouse killed by colliding with a fence. Raptors hunt primarily by riding air currents and spotting prey, not by sitting on a power pole. The Plan gives no documented evidence that power lines are a problem. // Power lines are important for habitat as they power water pumps for supplying water to livestock/wildlife. // Re: Section VI, page 21; It must be emphasized that burying power lines would be very difficult both technically and economically.

Sage grouse collisions are probably more likely with fences located on ridges or in swales (Call and Maser 1985) where low flying birds have less time to avoid collision. Raptors common to Montana including red-tailed hawks and golden eagles utilize perches, such as a power pole, to hunt from (Sibley 2000). The presence of elevated perches in a prairie environment are an attraction for hunting raptors and their impact may be more pronounced when located adjacent to a lek (Svedarsky and Van Amburg 1996).

We agree powerlines to water wells and fences are important for managing grazing. Our purpose in including this information is to inform land managers of the issues and provide potential strategies for mitigating their impact. Local discretion is necessary to determine whether these types of improvements might impact sage grouse. We believe designing and planning fences and power lines to reduce potential impacts on sage grouse is another facet of conserving effective sage grouse habitat.

\section{VEGETATION}

WAFWA guidelines are not appropriate for E MT. 7" stubble height is almost impossible, even with abundant moisture. 4" is more appropriate. WAFWA guidelines should not be adopted. Instead, habitat criteria in the Plan needs to be flexible. It would be beneficial for local working groups to develop guidelines to manage specific areas that consider climate, soil types, and rainfall. // If inexperienced grouse enthusiasts apply the Connelly guidelines to E MT, they are likely to recommend actions that would jeopardize our ability to graze livestock. The guidelines should be developed based on our ecosystem. // Re: Section VII, Pg 9. Nesting cover stubble height should be based on habitat types. Is height based on leaf height or seed head length?

We believe there is a basic misunderstanding of the role the habitat descriptions provided in Sections III, IV, and VII will play in sage grouse conservation. To clarify this, additional information has been added to these Sections to better define how they will be applied to the landscape.

Connelly et al. (2000b) summarized habitat research over much of the sage grouse's range, some of which is included in the Plan. Researchers have considered a variety of measurements when looking at breeding, nesting, brood rearing, and winter habitat. Each study has taken different measurements and has provided somewhat unique characteristics related both to local conditions as well as differences in measuring technique. Although there are a number of variations between studies, there are also common themes. For instance, sage grouse nest sites are almost always placed under sagebrush plants and are often times associated with the tallest sagebrush within a stand. In similar fashion, residual grass height is most often higher at a sage grouse nest site than at random sites (Connelly et al. 2000b, Heath et al. 1998).

The term "stubble height", which implies an even stand of grass stubble such as a harvested grain field, was purposefully not used in the Plan. As described above, sage grouse nest sites are carefully selected by the laying hen to best conceal nests. Therefore, nest site characteristics, such as 
those described in the Plan, cannot be extrapolated over an entire pasture. Environmental variables, such as soil textures, topography, grazing accessibility, and weather result in a patchwork of shrubs, grasses, and forbs of varying heights, canopy coverage, and species. Potential nest sites, therefore, occur within patches of cover over the landscape.

We agree that in some parts of Montana the predominant grass species and/or moisture regimes limit the ability of a particular site to produce very tall residual cover. In Table 1 of Connelly et al. (2000b), they listed grass height at sage grouse nest sites based on a number of studies ranging 14-34 cm (5.5-13 inches). They further stress (Page 978) height requirements be developed "that are reasonable and ecologically defensible." The variability between studies is likely a difference in site potential, predominant grass species, and weather. Local working groups will need to adapt guidelines from the Plan to individual circumstances.

The Plan substantially abandoned Connelly's quantifiable guidelines for conservation actions regarding understory condition (i.e. $18 \mathrm{~cm}$ of residual understory for spring nesting cover). This was based on scientific information, it is not mandatory, and it shouldn't be struck because of political considerations.

We believe the plan effectively describes sage grouse habitat based in part on a summary of research by Connelly et al. (2000b) and provides necessary flexibility for guidelines to be adapted to local habitats. The importance and characteristics of quality breeding, nesting, brood rearing, and wintering habitats is clearly expressed in the Plan.

I disagree that sage grouse require specific height forages in order to survive. If it were so, years like 1988 would not be listed in Table III-1.

Height conditions of grasses and forbs serve the dual purpose of concealing sage grouse nests, broods, and individuals and providing food. We agree that other factors also influence short-term sage grouse abundance such as weather and predation (Section III). Drought conditions, which are characterized by poor herbaceous production, generally result in lower rates of nest success. During years like 1988 and 2001, sage grouse recruitment is likely very low.

The Plan does not adequately describe that these systems are dynamic and require some form of disturbance to ensure "...a shifting mosaic of sagebrush communities that meet sage grouse habitat requirements..." Specific criteria such as Table VII-2 with numerical ranges suggests that we can "maintain" canopy cover and heights of sagebrush, grass, forbs in "desired" ranges. The Plan overemphasizes structure and de-emphasizes incorporating appropriate processes.

Re: Section VII Pg 8-9. Once attained, how will criteria for "suitable habitat" be kept in those ranges? Re: Section VII Pg 15. What "specific guidance" will ensure a shifting mosaic of sagebrush communities? Has it been developed yet? // Re: Section VII, Pg 15. Nothing in Research Needs relates to the need for more specific guidance concerning a "shifting mosaic" of sagebrush communities.

Our use of the term "shifting mosaic"(Section VII page 15) was intended to mean changing patterns of land use and disturbance that affects sage grouse habitats geographically and temporally. Our purpose in listing this as a research need was to help determine what threshold levels there may be in habitat function beyond which, long-term sage grouse survival or productivity are negatively affected. We agree disturbances such as grazing, weather patterns, fire, and herbicide spraying influence sagebrush habitats in different ways. We have described in the Plan how each of these affect sagebrush communities and sage grouse directly (Sections V and VI). Also, we have added a preface to Section IV that describes how these various disturbances as well as influences of soils and topography result in a patchwork of varying canopy coverages, heights, and plant species compositions. At a given location, multiple factors influence vegetative characteristics. In Section VI, the Plan lists specific management actions for land managers to consider that will help maintain or improve effective sage grouse habitats. 
There is no need from the standpoint of management to breakdown Artemesia spp into all the sub-species you have described. Next USFWS will want to list a subspecies of sagebrush.

Subspecies of big sagebrush are adapted to distinct moisture regimes, soil textures, and soil depths (Wambolt and Frisina 2002). We believe it is important to identify these subspecies as they fill specific habitat niches across Montana.

Does FWP set objectives for sagebrush canopy coverage in its conservation easements?

FWP includes stipulations in conservation easements that protect sagebrush-grasslands from burning, herbicide application, and tillage. Conservation easements on sagebrush-grasslands also include a rest rotation grazing system that helps ensure residual cover and a diverse mix of forbs, grasses, and shrubs will be maintained on the protected property. Whereas sagebrush canopy coverage may vary somewhat over time due to a variety of factors, we believe sagebrush will continue to occur where it presently occurs based on historical accounts (Harrington 2002), habitat type descriptions (Mueggler and Stewart 1978, Hansen et al. 1995) and research in other states that describe sagebrush as a climax species (Daubenmire 1970, Welch in preparation).

Re: Section I, Pg 2. We recommend a stated objective of a mix of sagebrush age and height classes be incorporated into this section. // Re: Section I Pg 2. Mid scale objectives focus on shrub cover and shrub height classes. What about age classes? Reproduction? Is the stand regenerating without disturbance? // Re: Section IV. The "use of prescribed fire...can result in a net loss of sagebrush...desire to maintain mature sagebrush community". Can we "maintain" a mature sagebrush community without some sort of disturbance? All things get old and die...we can't maintain "mature" forever. // Re: Section VI Pg 29-30, Vegetation Table. The First goal should read "and no long term net loss of sagebrush habitats". You manage for the long term. At times a short term loss is needed to gain the long term goal. Ex. use of prescribed fire may take 10 years before it will again support a breeding hen, depending on the mosaic left after burning.

Big sagebrush stands do not require disturbances such as fire or grazing to be perpetuated (Beetle and Johnson 1982, Peterson 1995, Welch in preparation). Although many big sagebrush stands have the gross appearance of being even-aged or decadent, close observation and age sampling often reveals a diverse age structure (Peterson 1995). Long-lived sagebrush stands actually have more opportunity for mixed age classes than do stands that are frequently burned (Welch in preparation). Depending on a number of factors including soils, vegetation, available moisture, and size of burn, sagebrush recovery from fire can easily require 30 years or more (Welch in preparation). Sagebrush species and subspecies that regenerate from seed, e.g., Wyoming and basin big sagebrush, often are eliminated if the site treated by prescribed fire is too large. Species that resprout from crowns and roots, e.g., silver sagebrush, three-tip sagebrush, and some forms of mountain big sagebrush, can re-establish if the fire intensity is not too high. Scientific literature on the effects of fire supports an argument against the use of fire to manage sage grouse habitats (Connelly et al. 2000a, Wambolt et al. 2002).

Re: Section I Pg 2. The ranges of canopy cover presented in section 2 ) a and b are not clear (e.g., $<1$ to $25 \%$ and 5 to $>25 \%$ ). Recommend using cover classes as described in the first draft consistent with work on sagebrush classification by $\mathrm{U}$ of MT. This is measurable.

The ranges described in Section I page 2, are parameters within which sage grouse habitat is likely to occur. As remote sensing techniques are refined, cover classes within these outside parameters may become distinguishable. Presently, however, sagebrush stands of less than 20 percent canopy cover have not been distinguishable from grassland habitats (Sections I and III). 
Re: Pg iii and Section III, Pg 2 and Section IV, Pg 1. What method was used to measure sage canopy cover? The Breeding Section indicates canopy cover of 20-50\%. Canopy covers in excess of 25\% are difficult to move through...it is difficult to imagine what a 50\% canopy would look like. This much canopy leaves minimal understory for feeding sites.

The 20-50\% sagebrush canopy cover measures were taken at strutting male feeding and loafing sites in the Yellow Water Triangle Area of central Montana (Wallestad and Schladweiler 1974). In the early part of this study, a $200 \mathrm{ft}$. line-intercept technique (Canfield 1941) was used and later a series of 30-4 X 10-dm quadrants were used. Both techniques reportedly yielded comparable data.

Re: Section III Pg 4. The 1972 study describes grouse use of greater than $20 \%$ cover averaging 10 inches in winter. What is the height of these stands today? What about the sage grouse in these areas today? A follow-up study should be completed.

We believe sage grouse research in other parts of the state is a higher priority. As many of the comments have pointed out, Montana lacks sage grouse habitat need information from other parts of the state. Whereas a follow-up study would also provide useful information, it is not the highest priority at this time.

Re: Section III, Pg 4: Winter Section. Wintering areas with 20\% canopy and sagebrush height of 10" is a very low-growing sagebrush. Are these results from Idaho that may not apply to MT? Are they heavily browsed or young stands?

These data were based on a study by Eng and Schladweiler (1972) in the Yellow Water Triangle. They classified their sagebrush height measures into 6 height classes, of which the majority of wintering sites were in the 6-12" height class. Snow conditions during this study ranged from 0 to 10 inches. As has been found in other studies, deeper snow would likely require sage grouse to move to taller sagebrush stands (Bean 1941). Most of the measurements were taken along Pike Creek Ridge, which was wind-blown and didn't support very tall sagebrush (Dr. Robert Eng, personal communication).

\section{WEATHER}

Weather/production information was confusing, common sense would suggest the prior year's precipitation would affect residual nesting cover and therefore production.

We agree that factors affecting residual nesting cover will affect nest success, including drought. Weather factors included in the Plan (Section III, Population Dynamics) focused specifically on how weather during the breeding and nesting period affected productivity.

\section{WEEDS}

Tame grasses invading into native prairie will continue to reduce habitat for grouse. Crested wheatgrass results in a monoculture.

We agree invasion of native grasses can be a problem in some areas. We have emphasized maintaining native range species in both the mid-and fine-scale habitat objectives (Section I). Conversion of native ranges to introduced grasses is also considered a form of habitat fragmentation (Section V). 
Re: Section VI, Noxious Weed Management. This has no place in the Plan. Annual forbs occur as a result of mismanagement. Loss of perennial vegetation and soil loss is the result of mismanagement. The first responsibility of land agencies is to protect soil fertility and prevent soil loss - this should be in the Plan.

Most noxious weeds are perennial or biennial forbs. Noxious weed occurrence can be a result of both mismanaged land that is more susceptible to weed invasion or simply seed spread by a variety of mechanisms, regardless of range health. Because noxious weeds can reduce effective sage grouse habitat, they are of vital concern to sage grouse habitat conservation.

Re: Section VI, Pg 10. Conservation Action \#2. We recommend evaluation of consequences of not using herbicides to control noxious weeds, which would have a long term effect on habitat.

This section referred to in the Plan is for Grazing Management and is directed at use of herbicides to increase forage for livestock grazing. We agree noxious weed control is very important to sage grouse habitat conservation. Issues and conservation strategies regarding noxious weeds are considered in Section VI, pages 14-17.

\section{WORKING GROUPS}

Recommend in place of Table VII-2 that local working groups develop habitat criteria.

As described in the Plan (Sections IV and VII), vegetative variability across sage grouse distribution in Montana, caused by area growing conditions and predominant plant species, will require agencies and local working groups to adjust the matrix, making it "reasonable and ecologically defensible" (Connelly et al. 2000b).

We believe it is appropriate for each local working group to manage for optimal habitat conditions on at least one breeding complex in each of the 3 to 4 major regions identified by FWP. Optimal Habitat Management Areas should be a first priority for Regional Working Groups and included in the Plan.

As described in the Plan, local working groups will be responsible for identifying issues and developing solutions based on information in the Plan and local environmental conditions. We are reluctant to further identify specific tasks of the working groups as each area of responsibility may require a unique approach, based on local circumstances.

Re: Section II, Pg 10. Modify first paragraph to read "Regional or local work groups will use the Plan as a basis for developing implementation strategies for their geographic areas of interest, taking into account local environmental conditions."

Similar changes were incorporated into this section.

Re: Section VIII, Pg 1. In the first paragraph under Local Work Groups, change the second sentence to read: "The work of the local groups, comprising a diverse group of stakeholders, will be to identify the issues in the area, describe local characteristics of sage grouse habitats, and develop and implement creative solutions to the issues."

Similar changes were incorporated into this section. 
Re: Section VIII, Pg 2. Under Scope Authority, change second and third sentences to: "Implementation of strategies will be accomplished in cooperation and consultation with local work group members and landowners. Actions on public lands will be achieved within the scope of agencies' existing policies."

Changes similar to these were made to improve readability while preserving the original message. 